\title{
American Social Science and Liberal Internationalism, 1865-1919
}

by

Brian M. Foster

A thesis submitted to the Faculty of Graduate and Postdoctoral Affairs in partial fulfillment of the requirements for the degree of

Doctor of Philosophy

in

History

Carleton University

Ottawa, Ontario

(C) 2012, Brian M. Foster 
Library and Archives

Canada

Published Heritage

Branch

395 Wellington Street

Ottawa ON K1A ON4

Canada
Bibliothèque et

Archives Canada

Direction du

Patrimoine de l'édition

395 , rue Wellington

Ottawa ON K1A ON4

Canada
Your file Votre référence

ISBN: 978-0-494-93674-0

Our file Notre référence

ISBN: $978-0-494-93674-0$
NOTICE:

The author has granted a nonexclusive license allowing Library and Archives Canada to reproduce, publish, archive, preserve, conserve, communicate to the public by telecommunication or on the Internet, loan, distrbute and sell theses worldwide, for commercial or noncommercial purposes, in microform, paper, electronic and/or any other formats.

The author retains copyright ownership and moral rights in this thesis. Neither the thesis nor substantial extracts from it may be printed or otherwise reproduced without the author's permission.
AVIS:

L'auteur a accordé une licence non exclusive permettant à la Bibliothèque et Archives Canada de reproduire, publier, archiver, sauvegarder, conserver, transmettre au public par télécommunication ou par l'Internet, prêter, distribuer et vendre des thèses partout dans le monde, à des fins commerciales ou autres, sur support microforme, papier, électronique et/ou autres formats.

L'auteur conserve la propriété du droit d'auteur et des droits moraux qui protege cette thèse. $\mathrm{Ni}$ la thèse ni des extraits substantiels de celle-ci ne doivent être imprimés ou autrement reproduits sans son autorisation.
In compliance with the Canadian Privacy Act some supporting forms may have been removed from this thesis.

While these forms may be included in the document page count, their removal does not represent any loss of content from the thesis.
Conformément à la loi canadienne sur la protection de la vie privée, quelques formulaires secondaires ont été enlevés de cette thèse.

Bien que ces formulaires aient inclus dans la pagination, il n'y aura aucun contenu manquant. 
The Department of History recommends to the Faculty of Graduate and Postdoctoral Affairs acceptance of the thesis

American Social Science and Liberal Internationalism, 1865-1919

\author{
submitted by \\ Brian M. Foster, B.A. Hons., M.A. \\ in partial fulfilment of the requirements \\ for the degree of Doctor of Philosophy \\ James Miller
Chair of the Department of History
}

Andrew Johnston, Thesis Supervisor

Kristin Hoganson, University of Illinois at Urbana-Champaign, External Examiner

Department of History

Carleton University

26 September 2012 


\section{Abstract}

In January of 1917, before America officially entered World War One, President Woodrow Wilson's administration received news that the British, French and German govermments had employed professional social scientists to gather and analyze data to prepare their nation's respective plans for peace. By September, six months after America entered the war, Wilson's chief confidant called together a large body of intellectuals drawn from progressive publications and top universities across the country. The members of the secretive group that developed, known only as "the Inquiry," understood that the new importance laid on social scientific methods across the Western world placed them in a particularly powerful place as mediators of the data that could literally objectivize social scientific knowledge into nation-states.

Using the Inquiry as an anchoring event, and incorporating recent work on state-formation and governmentality, this thesis offers an historical examination of the relational development of American social sciences and liberal internationalism following the American Civil War until the Peace Talks of World War One. Its unique contribution is to view internationalism not only as a product of state formation or an expression of governmentality, but as a technology used, and assisted by social scientific knowledge, to arrive at and make sense of those very state forms.

Combining literatures on the history of American state-formation, liberalism, social science and internationalism, this thesis shows how the problem of how to order the world into a recognizable international sphere created a demand for "universal" knowledge about governance, to which the social sciences were able to lay claim. Supported by a widely-held faith that America reserved an exceptional place for scientific experts and their knowledge in the management of states and society, one particular ideal type of liberal international society became the accepted pillar of internationalism we have today. The ideal type revolved around social scientific expert mediators working outside the state but invested in upholding the specific power relations ossified therein. At the same time, as social scientific knowledge shaped internationalism, the reigning concept of internationalism, built upon key liberal principles, had a tremendous influence on the disciplinary shape, methods and concepts of American social sciences as we know them today. 


\section{Acknowledgements}

A philosopher once told me that historians are like glaciers: slowly we move, gathering material wherever we go, traveling great distances, and rearranging the world in new, unfamiliar patterns. We destroy the past while creating new terrain that both defines future horizons and instills a sense of continuity with a past that can never be recovered. In traveling across so much space and time I have accumulated many debts that have directed my course, and shaped me as much as whatever humble mark I leave.

I would like to express my immeasurable gratitude for my adviser and long-time mentor, Andrew Johnston. This work owes much to his counsel, keen eye for empirical and editorial detail, and knowledge of so many disciplinary terrains. For near a decade Andrew has watched over my intellectual wandering, giving me the freedom to strike out into new areas but providing the guidance needed to anchor me to the demands of academia. To Carleton History: I arrived largely by chance, but I will never forget the community, where theory and history were treated as synonymous. In this vein, my sincerest thanks to James Opp, Bruce Curtis, John Walsh, Susanne Klausen, Sonya Lipsett-Rivera, James Miller, Pamela Walker, and Dominique Marshall. Their encouragement and advice were calm harbours in oft-stormy academic seas. To Maureen Mahoney, David Tough, David Banoub (the Daves), and Tamara Krawchenko and Tyler Knowlton, who animated my writing so that, to borrow from Frederich Nitzshce, it possessed not only my own spirit but also that of my friends.

Over the years I have received generous financial support from a number of institutions: Carleton History, The Faculty of Graduate and Postdoctoral Affairs at Carleton, the Social Science and Humanities Research Council of Canada, the Ontario Graduate Scholarship, and the Naida Waite Graduate Scholarship. These helped sustain my studies and extensive archival research across the US. They also assured that my academic apprenticeship struck the necessary balance between work and intellectual discovery, a balance that seems ever more a luxury for graduate students in this age. I would also like to thank the archivists and librarians at Yale Manuscripts and Archives in the Sterling Library, the National Archives and Records of the Administration at College Park, The Manuscripts Division of the Library of Congress, The Department of Special Collections and Archives at Johns Hopkins's Sheridan Libraries, Houghton Reading Room and the University Archives at Harvard, The Division of Rare and Manuscript Collections at Cornell University, and the Special Collections Research Centre at the University of Chicago's Regenstein Library.

This thesis, like all my academic work, would have been impossible were it not for my family. I dedicate this work to them - to the pride and the encouragement shown by my parents, Bill and Sandy, and my siblings, David and Jenny. They gave me much needed respite when things were roughest. I thank my sister Sarah, who taught me from a young age that 
labels structure our actions in the world and our relations with others, but they must never be allowed to determine the horizons of possibility. And last but most importantly, this is for my wife Karen. I am here because of her endless understanding, patience and fortitude. Her good nature and her discipline as a sociologist equipped her for not only the countless hours of listening, reading and editing on my work, but to rouse me and push me on when I most needed encouragement. In her I have met my match and a lifetime collaborator. 


\section{Table of Contents}

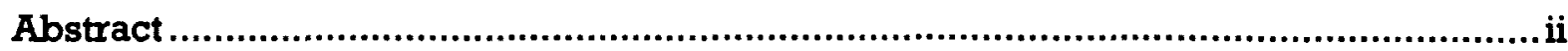

Acknowledgements ..................................................................................................ii

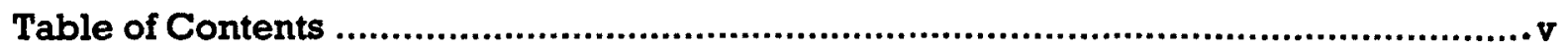

Introduction

Drift, Mastery and a Scientific International.............................................................. 1

Chapter One

The International As a Governmental Effect in American Social Science .................... 25

Chapter Two

"Sovereignty is only a means:" Social Science, International Law and "The

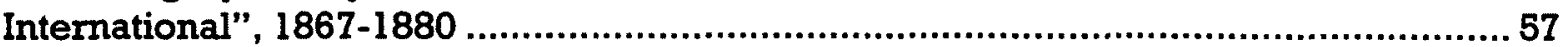

Chapter Three

"A Mandate From Humanity": Disciplining Social Science and Internationalism, 1880-

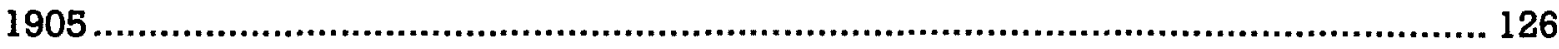

Chapter Four

Leaving the "Age of Nations": Social Science in an age of Global War .................... 209

Chapter Five

The Inquiry and The Non-State International Expert .............................................2279

Chapter Six

Secrecy and Scientism: Radicalism and Self Discipline in the Inquiry .......................369

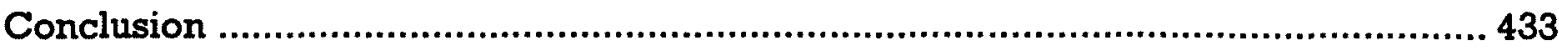

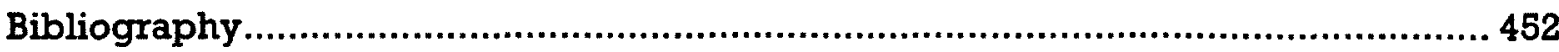




\section{Introduction: \\ Drift, Mastery and a Scientific International}

What men need in their specialties in order to enable them to cooperate is not alone a binding passion, but a common discipline. Science, $I$ believe, implies such a discipline. It is the fact that scientists approach the world with an understood method that enables them to give and take from each other whether they live in Calcutta or in San Francisco. ${ }^{1}$

-Walter Lippmann

...Theory does not express, translate, or serve to apply practice: it is practice. But it is local and regional... and not totalizing. ${ }^{2}$

-Michel Foucault

Though he was only 28 , Walter Lippmann was a seasoned intellectual and political insider by 1917. The co-editor of The New Republic had befriended and impressed Presidents, political advisers and some of the most prominent Progressives of the era with monumental works such as his 1914 Drift and Mastery, which was praised for articulating the modern tensions that seemed to tear at America's social fabric. America was no longer a "Nation of Villagers" made up of small-minded entrepreneurs looking to hold back collective organization and industrial progress. Rather the US possessed a special, prominent place for the "new type of administrator, the specialist, the professionally trained business man,"3 a harbinger of the expanding social

\footnotetext{
'Walter Lippmann, Drift and Mastery, (Englewood Heights, N.J.: Prentice Hall, 1961), 154-155.

${ }^{2}$ Michel Foucault and Gilles Deleuze, "Intellectuals and Power: A Conversation Between Michel Foucault and Gilles Deleuze.," in Language, Counter-Memory, Practice, ed. Donald F. Bouchard (Ithaca: Cornell University Press, 1977), 165-197.

${ }^{3}$ Lippmann, Drift and Mastery, 83.
} 
connectivity that was "blotting out village culture, and opening up national and international thought." 4

Like many of his colleagues, Lippmann saw the outbreak of the First World War as a tragic opportunity to impress upon others the importance of such administrative mastery. With Europe awakened to the catastrophic implications of imperial states and old diplomacy, Lippmann felt a scientifically-managed nation could prevent people from "turning back to their oldest associations...for a pride in what they came from which obscures the hopes of their goal." Looking forward, Lippmann held out hope that establishing democratic governments in smaller states would destroy the extremes of global imperialism and parochial tribalism, removing the allure of colonial and administrative possessions in far off lands while also extending and democratizing the control of diplomacy "in the so-called civilized nations." He proposed that, by organizing "backwards" frontier zones and liberalizing imperial states, it was possible to remove the "stakes of diplomacy" and replace them with a truly international system built on broadbased governance. $^{6}$

Fired up by Woodrow Wilson's optimism, Lippmann strongly endorsed the President's efforts to insert the US into the war in 1917. This support was acknowledged when Wilson's chief confidant, Colonel Edward M. House, requested Lippmann join several other prominent intellectuals in 1917 to work

\footnotetext{
4 Ibid., 87.

${ }^{5}$ Walter Lippmann, The Stakes of Diplomacy, (New York: H. Holt, 1915), 6-7.

${ }^{6}$ Ibid., 186-192
} 
on a secretive group that would be known only as "the Inquiry." Lippmann took up with the small group of men, pulled from liberal publications and the halls of American academe, and the secretive group grew quickly over the next six months. Its members were drawn from tight, concentric professional circles that shared a faith in Wilson's vision, both of a universal liberal peace to make the "world safe for democracy", and of a world mediated by professionally trained administrative specialists. They also shared two crucial beliefs. First, they sincerely held that they could articulate the deeper social principles that would provide the foundations for what William $\mathrm{H}$. Buckler, a diplomat and future member of the American Commission to Negotiate Peace, called "a scientific peace". "They also believed that maintaining the appearance of disinterested scientific disciplines was the best hope for avoiding the partisan pitfalls of international governance on the basis of raison d'état and the balance of power. Both beliefs, as this dissertation will show, have had diffused but profound consequences for the concept and practice of internationalism as we know it today, the expression of American exceptionalism, and the place of professional social science disciplines vis-àvis national and international governance and foreign relations. Together, these two beliefs and their expression form the core of the relational development of professional social science and internationalism.

\footnotetext{
${ }^{7}$ Lawrence Gelfand, The Inquiry: American Preparations for Peace, 1917-1919 (New Haven: Yale University Press, 1963), 16.
} 
The American administration was not the only state to call together social scientific experts. By January of 1917, the Americans were aware that the British, Belgians, French and Germans were already hard at work, generating reams of data on the world's populations and territories. Far from being intimidated by this, many members of the Inquiry understood that the new global significance being afforded to social scientific principles placed them in a particularly powerful position as mediators between stategovernments and the data that literally objectivized societies. Moreover, with a mandate to make the "world safe for democracy", the American social scientists believed in their role as altruistic carriers of a universal liberty, especially when compared to their European colleagues who seemed to work for and within the powers of the state rather than the values of humanity as a whole. Confident in the social and scientific universality of their principles, and frustrated by British and French refusals to issue a shared statement of peace objectives in 1917, the Inquiry's Executive penned the influential memorandum, "A Suggested Statement of Peace Terms," barely two months after forming. Though Wilson would modify it heavily, that memorandum provided much of the language, not least the increasingly ubiquitous and contested notion of "self-determination," and the key peace objectives that Wilson would articulate in his famous Fourteen Points Speech of January 8, $1918 .^{8}$

${ }^{8}$ Gelfand, The Inquiry, 134-155. 
The Inquiry continued to grow in the months that followed, and so too did the confidence of its members. Six months after authoring this memo, Lippmann wrote to Colonel House that the only way to a "broad base for diplomacy" was to extend the reach of the Inquiry members beyond the reports and papers they had written. He advocated the group's insertion into any planned peace and League of Nations talks via a secretariat that would "control the world's latest and best information on all political, economic, and social questions which could possibly be brought before the peace delegates."9 For Lippmann, a scientific peace that bridged the gap between civilized and emergent nations, and that balanced state sovereignty with humanity's shared cosmopolitan interests, could only be managed by a meritocratic-scientific elite. Bound by the common discipline of science, these new administrators, who would help usher in and guard a broader democratic system, represented the best hope for a "new diplomacy" and a truly liberal international. ${ }^{10}$

Despite Lippmann's early optimism, a year after joining the Inquiry, the young journalist was pressed out of the secretive group by a small cohort of academic social scientists. Lippmann's ability to articulate complicated ideas had attracted Wilson's adviser to him, but his approach set him apart from the

\footnotetext{
${ }^{9}$ Lippmann to Colonel Edward H. House, 28 June 1918, Edward Mandell House Papers (MS 466), Manuscripts and Archives, Yale University Library. (Hereafter House Papers)

${ }^{10}$ For more on Lippmann's falling out with socialism see Barry D. Riccio, Walter Lippmann-Odyssey of a Liberal. (New Brunswick, N.J.: Transaction Publishers, 1994), particularly pp. 1-29. For more on the thinking on social control in the radical liberalism of Lippmann, Herbert Croly and Walter Weyl see, Christopher Lasch, The New Radicalism in America, 1889-1963: The Intellectual As Social Type, (New York: Alfred A. Knopf, 1965), 181-183.
} 
disciplined line taken by the Inquiry. In his The Stakes of Diplomacy, Lippmann remarked:

[T] he things we have to think about are so unreal to us. We are feeding on maps, talking of populations as if they were abstract lumps, and turning our minds to a scale unheard in history....How many people have ever heard of the Szekels of Transylvania? Yet there are over 800,000 of them, all entitled to a place in the sun and all capable of making trouble if it is denied to them. When you consider what a mystery the East Side of New York is to the West Side, the business of arranging the world to the satisfaction of the people in it may be seen in something like its true proportions."

This kind of thinking arguably led an influential core of the university-trained social scientists in the Inquiry to dismiss Lippmann as ill-fitted for his role as co-head of Research. Because he came from the cut-and-thrust world of politics and journalism, Lippmann lacked the very discipline he imagined binding the world together. It was not that Lippmann lacked any discipline; rather, he lacked the proper disciplinary knowledge with which to anchor these social abstractions to reality. Lippmann had understood the problematic nature of nations that could be defined and measured by territory and population. Far from being normative or absolute categories for understanding and managing the world, Lippmann understood forms of social solidarity such as the nation as contingent phenomena. "We have taken refuge in abstractions like Nationality, Race, Culture," he argued before joining the Inquiry, because "they are easier to think about than men." The world was an infinitely complex space, observations of it inevitably mediated

\footnotetext{
${ }^{11}$ Lippmann, The Stakes of Diplomacy, 11
} 
by historical and social knowledge that was dependent on where, why and how it was generated. Anyone "who claimed that he was not bewildered" by the complexity of the world, he warned, "would write himself down a fool."12

Facing this complexity as a commentator, Lippmann saw militarism and pacifism as "extremes," calling them irrational and ill-fitted to "a time for deeds, not words." But once inside an institution charged with distilling such complexity to a manageable and governable political scale for the state, his calls for definitive and disciplined action were turned back on him, and he faced growing criticism for failing to manage the group of mostly social scientists towards realistic ends. Facing a full-out mutiny, Lippmann left the Inquiry for an Army intelligence job in Europe.

Historians have touched on Lippmann's influence over the Fourteen Points speech, but the story of his waning influence in the Inquiry and his strained relations with the cohort of self-identified professional social scientists has not received thorough attention. ${ }^{13}$ This is unfortunate because it highlights an important theme and related questions that have also been under-explored in American foreign relations history: more than simple interpersonal difference-though it would manifest itself as that-the

\footnotetext{
${ }^{12}$ Ibid., 11-12

${ }^{13}$ For a work that touches on Lippmann's influence on the Fourteen Points see Ronald Steel, Walter Lippmann and the American Century (New York: Transaction Publishers, 1980), 133-134; Neil Smith, has touched on the coup, though he focuses on the tensions between Lippmann and Isaiah Bowman, reflecting his archival base. and misses many of the epistemological tensions between Lippmann and the social scientsts of the Inquiry, American Empire: Roosevelt's Geographer and the Prelude to Globalization (Berkeley: University of California Press, 2004), 122-125.
} 
methodological and epistemological differences between Lippmann and the social scientists provide a vista onto the contested terrain of internationalism. ${ }^{14}$

At its most basic, this work understands internationalism as the relations between people organized into nations. This organization occurs at conceptual and practical levels. It depends on the recognition of national boundaries, reflected in the geopolitical purview of the state, with its claims to juridical sovereignty over the people within its territorial boundary, and the placement of the nation at the core of a global system, above and beyond any other solidarity, be it class, race, religion, or something else. Around the axis of the nation, internationalism is additionally the ideal of an organization that balances the tensions between national independence and global security and cooperation. ${ }^{15}$ Yet, just as the questions of how to govern and who was best fitted to do so were not settled at the local level of the nation-state, their resolution in the international sphere was contested.

Thus, internationalism is treated in this thesis not as a universal concept but as a conceptual space that has been modified according to various contestations throughout history. Accordingly, my concern here, to borrow from Mitchell Dean, is where and why internationalism was identified as a problem, and how it was rendered thinkable, knowable and actionable in

\footnotetext{
${ }^{14}$ See Smith, American Empire, 122-135, for one telling of this tension between Lippmann and key social scientists through the lens of a battle over the political economy underpinning American internationalism.

${ }^{15}$ Kjell Goldmann, The Logic of Internationalism: Coercion and Accommodation (New York: Routledge, 1994), 1-2.
} 
certain historical and sociological contexts. ${ }^{16}$ If an international system is merely one way of ordering the anarchical world, then the Lippmann-Inquiry episode also raises the question of how this obvious skirmish around defining the problem of "the international" and practicing "internationalism" connects to the disciplinary and methodological formation of the social sciences in America. On the one hand, battles over the scope and epistemological assumptions at the base of social science in America were, by extension, delimiting the acceptable definition and practices internationalism. But, on the other hand, the complex currents of debate over the meanings of liberalism, nationalism, and democracy among the generation of American "Progressives" who wrestled with and tried to make sense of global events, reveal competing ideas of how "the international" ought to be defined and addressed as a matter of national policy.

This thesis is, thus, an historical exploration of the emergence and contestation of what has become known as liberal internationalism, in a period of American history when the study of history, politics, the social, and economics became distinct fields (disciplines) of knowledge and study. It treats the concurrent rise of these new disciplinary social sciences on the one hand and burgeoning practices and concepts of internationalism on the other not as a coincidence, but as a relational development of knowledges aimed at the creation of a locally familiar and yet universally applicable order. There

\footnotetext{
${ }^{16}$ Mitchell M. Dean, Governmentality: Power and Rule in Modern Society (Thousand Oaks: Sage Publications Ltd, 2009).
} 
are two prongs to the basic argument in the pages that follow. The first is that in order to have any applicability to the emerging problem of internationalism, the social sciences had to provide a form of knowledge that was comprehensible through the primary lens of the nation. Timothy Mitchell has argued that "the possibility of social science is based upon taking certain historical experiences of the West as the template for a universal knowledge,"17 and much the same can be said of "the possibility" of internationalism. It too has grown from the West's "historical experiences" put forward as "the template for universal knowledge." This dissertation proposes that the social sciences and liberal internationalism in the United States co-constituted each other between 1867-1919, each having to confront the need to balance an expanding world, increasingly in-view and in-reach, with a desire to order that world into a regulated and secure space recognizable to certain Americans.

Liberal internationalism's history is, then, the history of an ideal societal form as well as of the real practices used to represent its possibility and plausibility. In most respects, the practice of liberal internationalism refers to the range of diplomatic relations and principles governing American foreign policy especially, but not exclusively, under Woodrow Wilson and his followers. But liberal internationalism also refers to the gradual development of these principles by a network of professional experts in aspects of social,

\footnotetext{
${ }^{17}$ Timothy Mitchell, Rule of Experts: Egypt, Techno-Politics, Modernity, 1st ed. (Berkeley: University of California Press, 2002).
} 
economic, and political theory. In short, the emerging social sciences in America provided a critical part of the practice of American diplomacy that became most influential and apparent under Wilson's watch. As this thesis will show, the social sciences in America provided a chief network for the creation of new forms of reasoning about the international and America's relationship to it. The international provided a conceptual structure that allowed social scientists to demonstrate their privileged access to knowledge of how to govern by performing certain methods and ideas, and being a part of certain institutional alliances, that were seen as apolitical or dissociated from both the state and those who would try to change society by undermining dominant social discourses. ${ }^{18}$

The second prong of the argument here is that, in looking at the disciplinary knowledge that solidified around internationalism in late nineteenth and early twentieth century America, it becomes clear that the classical liberal distrust of "the state" has had an impressive formative impact on contemporary structures of internationalism. This endemic suspicion of the state cut two ways for social scientific reasoning and articulations of internationalism. On the one hand, distrust of any knowledge seen as enstated created an opening where the authority to govern in societies, and the right to claim sovereign statehood, were wrested away from the demos as contained by a state, and instead placed in the flexible and contingent

\footnotetext{
${ }^{18}$ For a discussion of the international as a rationalized "space" that was viewed as governable, see Wendy Larner and William Walters, Global Governmentality: Governing International Spaces (New York: Psychology Press, 2004).
} 
structure of "the nation". On the other hand, by placing the authority to govern or to direct governance outside the state, and in seeing governance as an expression of the social solidarity imagined as the nation, the privileging of non-state knowledge created a highly contested ontological space. In this space the ability to represent and articulate the social forces at the base of a society depended on the ability to perform the role of disinterested observer. And yet to present this role properly, social scientists of the Inquiry had to tread lightly around contested or controversial social questions, such as race, class, gender and the exceptionalism of the American nation-state. This, I propose, has historically left many liberal social scientists in the awkward position of having to acknowledge that they are in a state, while also proving that their knowledge is not "of" that state.

The de-stating of governmental knowledge I discuss, and the view of it as somehow less politicized for its existence in social or civic spheres apart from the state, marked a departure from conceptions of governance found in a great deal of European political philosophy and sociology at the same time, even within otherwise liberal societies. ${ }^{19}$ In looking at the development of

\footnotetext{
${ }^{19}$ Progressive liberalism had this ambivalence about politics at its core following the class and labor scares of the Gilded Age. On the one hand, politics was for many progressives seen as something emotional, irrational, and prone to corruption - a view that was largely an intellectual vestige of republicanism - that positioned virtue, as the axis of social solidarity in the nation. This virtue was meant to cut through constituent factions, be they ethnic or, more likely, class in the late Gilded Age and Progressive period. And yet, on the other hand, the aim of reform was to further democratize American society, to spread the virtues of the republic and bring the power of the people more to bear on the instruments of the state. Progressivism, then, understood democratic renewal as the ability to move past constituent differences and towards a reconciled social solidarity built around ideals of common For more on the rise of the progressive movement and the social philosophy and language it developed to create this proto-functionalist ideal of the way society could function cooperatively see Shelton Stromquist, Reinventing "The People": The
} 
social scientific rationalizations of internationalism, however, we see that this ideal of diffused governance paved the way discursively for a new and highly diffused regime of governmental power in the US, which fundamentally shaped American expectations of how the international sphere ought to be thought about and controlled. As we will see, this shift introduced a new metric with which to measure societies, populations and statehood, as well as accompanying new ways of deploying those metrics to judge other societies' positioning within an international system.

To arrive at a more pointed study of the concepts and practices of governance that allow us to understand the relational development of the social sciences and internationalism, Chapter One outlines what I propose is the theoretical and ontological language that historians ought to engage with. It argues that, by viewing internationalism as an "effect" created by rationalities assumed to be fundamental to governance, we can begin to treat social science as a language that gave shape to the ideal societal structure that many progressives imagined as the international. Connecting literatures on the history of American social science, liberalism, state formation and internationalism, I offer a theoretical framework and clarify important terms and themes that recur throughout the remainder of the thesis. Chief among these themes is the idea that when internationalism is historicized through the 
lens of governmentality it loses any universal or formalistic structure, instead becoming an effect of local reactions to the changing conditions and restive forces that confronted Americans in an increasingly modern world. By looking at debates over the nature of internationalism and the US state form in American liberal social scientific circles, it becomes evident that "the international," in all of its iterations, can be consistently seen as an effect of efforts to universalize local understandings and desires to structure the world into an orderable space. This may seem like a pithy observation, but when used to explore the development of social science in America we see that the efforts of liberalminded practitioners to communicate the benefits of liberal society and political economy at home developed a cognate regime of liberal internationalism. This liberal internationalism imagined the data, disciplines, and institutions that delimited and directed internationalism as guided by scientifically disinterested intermediaries who could bridge the gap between states and societies.

Chapters Two and Three carry this theoretical argument forward by offering a more empirically grounded genealogy of early American social scientists' efforts to articulate the practices and structure of internationalism. It shows how liberal reformers used and developed a particular idea of internationalism to push back rival political systems, demonstrating their exceptional capacity to create disinterested social scientific knowledge in transnational institutions. Key to this push-back was the use of a particular idea of the European state form and European societal tensions as a foil to 
prove the comparatively disinterested nature of American knowledge. Using a series of events that highlight competing concepts of sovereignty and the state, and conflicting methods for organizing the international around those ideas, Chapters Two and Three also explore competing modes of liberal internationalism in American social science from 1867-1904. I find that, although liberal social scientists during this period debated the precise role of the state in facilitating a more egalitarian socio-economic order, the shared three interconnected commitments. First they adhered to and believed in a liberal political economy that directed social organization through civic or social forces circumscribed by state. Second, they believed that the deeper principles at the base of this political economic order provided the foundations for a sustainable international system. Finally, they emphasized the importance of developing seemingly disinterested scientific social knowledge anchored to and concerned with these non-state spheres.

Starting with Reconstruction and the Gilded Age (1867-1890s), Chapter Two shows how this shared faith in non-state knowledge and social scientific expertise developed by looking at debates in the 1860 s and early 1870 s over which non-state institutions were the proper vessels of international practices, and what role the state would play in facilitating its own demise in such a system. These debates, I argue, generated two variants of liberal internationalism: what I call "social" and "civic" internationalism, and describe with more precision in the following chapters. Social internationalists, I argue, held the nation-state to be a temporary state-form 
that could facilitate the move to a larger world-state, while civic internationalists argued that the state's role was to serve as the expression of standards and norms set in the non-state, civic sphere, and which were the fundamental basis of the nation. For these later reformers, America was exceptional precisely because of its conception of a virtually stateless form of governance; what Alexis de Tocqueville admired as a "society [that] governs itself," and what Karl Marx later derided as a "fictive state" trying "to realize itself as pure society." 20 However, I argue that the tensions between civic and social internationalists mostly disappeared after 1873, following the emergence of a highly articulated socialist and labour internationalism that in many ways culminated with the Paris Commune in 1871 . Following the work of Joseph Lieber and the circle of American Social Science Association (ASSA) reformers that mostly developed around his view of America as an exceptional liberal state, Chapter Two explores the transition from social to civic internationalism among social science professionalizers, and the commonalities and discrepancies between them.

Chapter Three picks up where Chapter Two left off, exploring the history of those historico-political scientists from the mid-1870s to 1890 s who radiated out from the transnational circles that created the ASSA to form new disciplines of social science and new ideas about what expertise could properly guide America within a larger liberal international system. For this

\footnotetext{
${ }^{20}$ Cited in Stephen Skowronek, Building a New American State: The Expansion of National Administrative Capacities, 1877-1920 (Cambridge University Press, 1982), 7.
} 
group, the ideal of America as an exceptionally "stateless" society, a view of the state not as an autonomous entity but as the will of society organizing itself, the nation-state achieved democratic liberty through the Anglo-Saxon cultural mores inscribed in civic institutions such as the university, commerce, common law and constitutionalism. And because social scientific knowledge was both an expression and justification of said institutions, it represented the proper basis of governmental authority and the acceptable means for spreading liberty abroad. By this formula, maintaining a state-form that reflected these values, and protecting that state's sovereignty, were jointly necessary to protect liberal values across the world. By the 1880 s and 1890 s, however, we see that the institutional and intellectual foundations of social science shifted with historical circumstances, creating a new fragmentation in American internationalism. Using the Venezuela Boundary dispute as a key event in a series of other formative moments in thinking about internationalism, including the Hague convention and American overseas expansion, Chapter Three shows that the fragmentation of the social sciences from a large reform-motivated body (the ASSA) into smaller, emergent professional identities (the American Historical, Economics, and Political Science Associations), along with the growing influence of historians, political scientists and economists working from industrially funded universities, shifted the privileged form of social scientific expertise in America. The oncedominant role of legalistic experts and institutions waned as academic expertise developed around the exploration of more explicitly "social" 
questions. Of course, legalism would remain integral to civic internationalists, who continued to push a vision of internationalism cemented by parallel legal institutions, such as an international court at The Hague, which imagined slowly cementing the civilizable people of the world into shared civic communities governed not by states but by shared norms and practices. But the historico-political school's critique of and distancing from legal institutions opened the way for a form of realism, built around a search for the social forces that could facilitate a social internationalism.

Chapters Four through Six are less sweeping than the first three chapters. They use the Inquiry as a pivotal event, moving outward from it and through a series of local power-struggles over social science from 1904-1919, exploring local attempts to shift the ontology of the nation-state more fully away from the European model, toward an international order that did not fall victim to the pitfalls of the state-centered imperialism and militarism that had caused the First World War. Focusing on key actors in the Inquiry, many of whom would eventually attend the Paris Peace talks in 1919, these chapters detail how the social and civic internationalisms already explored were further modified and variously emphasized by social scientists who worked to place American social scientific practices and knowledge at the core of the liberal internationalism that would later come to be known as Wilsonianism. Working with different and sometimes rival ontologies of the liberal nation, social scientists used the crisis of the war, Woodrow Wilson's famous call for a "world safe for democracy" and, later, the principle of self-determination, to 
make their work more integral to fortifying American exceptionalism, which was increasingly synonymous with liberal internationalism itself.

Chapter Four opens with the story of James T. Shotwell, a key future member in the Inquiry. Tracing the shifting relationship between social science and internationalism from the time of Theodore Roosevelt (1901-1909) through to Woodrow Wilson's call to war in 1917, this chapter uses the tension between serving the state and serving a professional and scientific identity that derived its authority from apparently existing outside the state, to show the development of social and civic internationalism leading up to the war. The first part quickly explores the internationalism of President Theodore Roosevelt (1901-1909), whose presidency was transitional in the movement of internationalism away from the civic internationalism that had dominated the Gilded Age and early Progressive Era, and towards the social internationalism that became most pronounced in Wilsonianism. Roosevelt's conception of internationalism, it proposes, was one of power politics couched in the ideology of "civilization". This introduced a more encompassing concept of internationalism that imagined the US as part of a global civilizing project, effectively "modernizing" American internationalism by pushing it towards a view of the international as bound, regardless of state and national identities, by deeper social laws. The latter were themselves premised on the idea of America as the most civilized and advanced nationstate. 
However, this modernization also brought the US into line with a statecentered imperialism that, for many Americans, uncomfortably resembled European imperialism and the European state form, eroding American claims to exceptionalism. The second part of Chapter Four juxtaposes Roosevelt's 1912 presidential platform for a "New Nationalism", with Woodrow Wilson's "New Freedom," arguing that Wilson attracted progressive and liberal social scientists with his concept of intellectual leadership directing the state through social scientific expertise "outside" the nation-state. Against the backdrop of a growing global conflict centered in Europe, supporting Wilson's 1916 re-election campaign was treated by many, including Lippmann, as a chance to snatch internationalism from state-entrenched, genteel intellectuals once integral to Roosevelt neo-federalist worldview. However, the experts newly inducted into the halls of political power because of their caché as outsiders and realists better able to scientifically represent society on a global scale, made them recognize early on that their own authority hinged on maintaining the appearance of a deliberate distance from the state apparatus. Here, the little studied National Board for Historical Services is especially instructive. This chapter shows how social scientists managed this delicate balancing act, but served as a harbinger for the shape of social science and internationalism to come.

Chapter Five picks up with the story of the Inquiry social scientists making their way to the Paris Peace Talks in 1919 and Wilson's increased faith in their capacities as scientific experts on international affairs. By tracing out 
the movement of the Inquiry from its conception to the movement of twentyone academic and professional social scientists that traveled to Paris, this chapter shows how the specialists used "sister" organizations in allied nations to loan legitimacy to the idea that they were more scientific because they were participating in a transnational epistemic community. But, it shows that, at the same time as they did so, they also pointed to the relationships of those other organizations with their respective states as proof that only the Americans had achieved a truly liberal organization: only the Inquiry, they said, had achieved the status of being "with, not of" the state, and therefore only they could lay claim to truly universal liberal knowledge-the only knowledge concerned with the international as a truly liberal space, built on social principles and shared interests, rather than on the satisfaction of competing state interests. Using this social scientific authority, the final section of this chapter traces how social scientists at Paris used their increased objective authority to also marginalize actively the remnants of the civic international tradition, binding on to and defining the Wilsonian emphasis on self-determination as a tool for ensuring their own importance while pressing out legalistic and state centered solutions as vestiges of the old order.

The final chapter continues to explore the Inquiry, looking at how the same emphasis on distance from the state that would allow them to press out legalists at Paris, was anything but the ushering in of a new age of social science liberated from politics and the state. Using the story of the Inquiry as a case study, this chapter illustrates how social scientists in the group 
capitalized on its ambiguous position as a simultaneously quasi-state/quasi civic organization. Their negotiation of this status involved, importantly, concerted efforts to lock out highly-regarded social scientists with rivaling ontologies of the nation-state. Chapter Six reveals that social scientists working with the Inquiry knew, and worked to manage, the "risks" of taking on these more controversial figures, because they threatened to undermine widely held conceptions of American (and social scientific) exceptionalism as inevitably anchored to the nation-state as territorialized sovereign entity. By taking stock of the gatekeeping and external criticisms of the Inquiry, we can begin to unpack the hegemonic role that American social science played in normalizing a particular form of the liberal state and, by extension, internationalism. The small event of the Inquiry reveals that a multiplicity of rationalities about internationalism existed, but only a particular kind of social scientific rationality would take hold within the organization, because it offered an understanding of global society that largely reflected the localnational significance placed on nationalism as the chrysalis of any state formation.

Taken together, the final three Inquiry-focused chapters described above propose that understanding the development of new social scientific practices and ideas around internationalism is integral to understanding the environment in which Wilsonianism developed. However, the purpose of this work is not to argue that the Inquiry was the determining force in the creation of Woodrow Wilson's liberal internationalism. Nor is it an attempt to argue 
that the historical development of liberal internationalism in America throughout the Gilded Age and Progressive Era culminated in the Inquiry, or that the Inquiry is an exceptional event that demands further attention. The aspirations of this thesis are not so grand. Instead, the Inquiry is treated as a climactic event, or moment, that is helpful in illustrating the evolution and power of particular concepts of internationalism. It shows how, with the outbreak of the war, architects of American foreign policy were talking about the world as international in some ways that were fundamentally different than the generations before them. Yet, by the time of the Inquiry, with the parsing of liberalism and the social sciences into an ever-smaller political and disciplinary world, the reliance on social scientific rationalities to articulate internationalism in American society created an increasingly limited view of its possibilities. The War certainly challenged the existing vocabulary of internationalism that had been carried forward from the age of the ASSA and into the imperial age over which Roosevelt presided. And yet, despite efforts to distance internationalism and social science from much of this language there persisted, if in a more implicit way now, a continued faith in the possibility of explaining the world through social principles beyond the state. More specifically, we can trace a surviving faith in the role of disinterested social scientific experts in steering the US away from the problems of the empires and imperial states that were the cornerstone of European internationalism. 
In this way, Walter Lippmann, whose words on the universality of science opened this introduction, was by no means unique in hoping that a new type of scientifically-minded expert would manage nation-states and provide the administrative and intellectual sinew of internationalism after the war. He was not alone in believing that America had, more than any other nation, a special and prominent place for the new scientific expert, a fact that he and many other Americans believed became even more apparent with the catastrophic implosion of the old European system of internationalism in 1914. Nor was Lippmann sensational or idealistic for believing that the war presented America with an unprecedented opportunity to anchor internationalism to the apparent certainty of social scientific norms and standards, circumscribed by the laws of nation-states yet answerable to deeper social principles that bound humanity together in a liberal, cosmopolitan community. In most respects Lippmann's view of a liberal international facilitated by expert mediators working outside the state was unremarkable. And yet it is precisely because it is unremarkable that it deserves our attention. 


\section{Chapter One:}

\section{The International As a Governmental Effect in American Social Science}

Society must be remade before it can be the object of quantification. Categories of people and things must be defined, measures must be interchangeable; land and commodities must be conceived as represented by an equivalent in money. There is much of what Weber called rationalization in this, and also a good deal of centralization. $^{1}$

- Historian Theodore M. Porter

To develop a thought's meaning, we need only determine what conduct it is fitted to produce: that conduct is for us its sole significance. And the tangible fact at the root of all our thought distinctions, however subtle, is that there is no one of them so fine as to consist in anything but a possible difference in practice. To attain perfect clearness in our thoughts of an object, then, we need only consider what conceivable effects of a practical kind the object may involve--what sensations we are to expect from it, and what reactions we must prepare. Our conception of these effects, whether immediate or remote, is then for us the whole of our conception of the object, so far as that conception has positive significance at all. ${ }^{2}$

-William James

\section{Governmentality and the International}

The International as Effect and Instrument of the State-Society Divide

To understand the relational development of social science and liberal internationalism, this thesis explores a series of contestations in America's professionalizing social scientific circles over what types of knowledge, social scientific or otherwise, would define, order, and act in the international. These battles, this chapter shows, were often about America's place and conduct in the international sphere, but at the same time, they were an extension of local battles between interpretations of the proper relationship between the US

\footnotetext{
' Cited in James C. Scott, Seeing Like A State: How Certain Schemes to Improve the Human Condition Have Failed (New Haven: Yale University Press, 1998), 22.

${ }^{2}$ William James, Pragmatism and Other Writings, ed. Giles Gunn (New York: Penguin Classics, 2000), 3 4.
} 
state and the society it was seen as circumscribing. A number of important works have already established that the social sciences' authority and identity hinges on the ideal that its practitioners possess disinterested methods to act as disinterested observers. ${ }^{3}$ Focusing on the American scene, this work explores how the development of social scientists navigated the discourses of their socio-political environment, methods, practices, and institutions as integral to international governance gave purchase to these claims of universal and "realistic" knowledge. That is, the ability of social scientists to make themselves relevant to the question of international governance, as it became increasingly pressing at the turn of the nineteenth century, helped legitimize their methods and practices among Americans concerned with the place of the US in a world whose interdependence was increasingly apparent. The search for what Lippmann called a common discipline was always bound and produced by localized power struggles among social scientists trying to balance universal knowledge about governance with the more parochial forces of American nationalism and exceptionalism, which held up that nationstate as a particularly "stateless" liberal form. In this way, the social sciences not only informed the representation of the international in American intellectual culture, the international had a reciprocal effect on the formation of the social sciences, providing a key site to demonstrate the efficacy of their

\footnotetext{
${ }^{3}$ For works dealing directly with the origins of objectivity in the methods and disciplinary divisions of the social sciences see, Theodore M. Porter, Trust in Numbers (Princeton: Princeton University Press, 1996) and Mary Poovey, A History of the Modern Fact: Problems of Knowledge in the Sciences of Wealth and Society (Chicago: University of Chicago Press, 1998).
} 
work, institutions and professions to the governance of society as a liberal totality. They provided, in other words, the critical bridge between an American exceptionalism that always verged on the narrowly parochial and a claim to universality that made American ideas indispensible to the world beyond its borders.

This thesis does not propose that internationalism in the US was necessarily or monolithically liberal, or that internationalism was determined by the social sciences. Perry Anderson has noted, in trying to redress the absence of literature on internationalism as a concept, that it has undergone a number of important adaptations, adjusting to fit a shifting understanding of nationalism-which Anderson rightly identifies as internationalism's cognitive "counterpart." Understood as "any outlook, or practice, that tends to transcend the nation towards a wider community, of which nations continue to form the principal units," by the late nineteenth century internationalism was most identified in the West with the Second International: that web of socialist and transnational labour groups that emerged out of the dialectical tension created by transnational capitalism's simultaneous attempts to champion hyper-nationalism and enlightenment universalism. ${ }^{4}$ While this thesis offers a more complex historical account of internationalism in late nineteenth century liberal thought and institutions, it is worth noting Anderson's point that both transnational socialist and pacifist movements, and free trade capitalism, helped force a constant rethinking of internationalism. However, the focus of

\footnotetext{
${ }^{4}$ Perry Anderson, “Internationalism: A Breviary," New Left Review 14 (2002): 6-14.
} 
my work is more on how Americans adapted the idea of internationalism to local power networks and struggles that resonated with pre-existing local knowledge about the world, while still maintaining internationalism's universalistic potential.

This is not to suggest, on the opposite end of possible objections, that internationalism was so malleable that one could bend and use it as one saw fit within local contexts. Rather, building on recent work on governmentality, this thesis proposes that the international is a bounded instrument and "effect" of particular historical discourses that afford some possibility for change, but which also structurally limit those possibilities. Internationalism cannot be understood as universal. Instead, it must be seen as an expression and tool of a governmental rationality, or governmentality, a part of the constellation of "mundane processes of spatial organization, temporal arrangement, functional specification, supervision and surveillance, and representation" that we consider integral to the modern state form. ${ }^{5}$ To study the international through governmentality is to explore both the practices of governing and the rationality of government that make governing in particular ways appear both necessary and possible. Governmentality is not just about how political institutions behave; it is also about the "discursive framework that renders their practices meaningful through the construction of particular objects (or

\footnotetext{
${ }^{5}$ Thomas Lemke, “An Indigestible Meal? Foucault, Governmentality and State Theory," Distinktion: Scandinavian Journal of Social Theory 8 (2007): 43-64.
} 
subjects) of governance." ${ }^{16}$ The international must be understood as both a technique and strategy by which American society was made governable, at the same time it is seen as an effect and object of these techniques.

\section{Governmentality and Liberal Internationalism}

Seeing the international as both an instrument and effect of governmentality is especially necessary to the study of liberal internationalism because of its precise, albeit fluid and relational, formations of ideas, ideals, and practices. Historians of international relations have long shown how liberalism's cosmopolitan aspirations and practices of transnational trade and humanism were strong acids on the Westphalian system of modern inter-state relations. ${ }^{7}$ But as a critique of state-monopolized sovereignty and politics, liberalism did not just erode the power of monarchies throughout the Enlightenment. By the nineteenth century, the liberal ideal of dispersing sovereignty to the individual and away from the absolute state also began to effect the interpretation of the "law of nations". This formal inter-state system, built out from the Peace of Westphalia in 1648, rested on two principles: first, a "balance of power" among states to help maintain the territorial integrity of at

\footnotetext{
${ }^{6}$ Jonathan Joseph, "The Limits of Governmentality: Social Theory and the International," European Journal of International Relations 16 (2010): 223-246.

${ }^{7}$ Stanley Hoffman, "The Crisis of Liberal Internationalism," Foreign Policy 98 (1995): 159-177; For an overview of IR specialists who have explored the political theory of liberalism and its international element from different angles see Barry Hindess, "Liberalism-What's In a Name?," in Global Governmentality: Governing International Spaces, ed. Wendy Larner and William Walters (New York: Routledge Press, 2004), 23-51; Bruce Curtis, "After 'Canada': Liberalism, Social Theory and Historical Analysis," in Liberalism and Hegemony: Debating the Canadian Liberal Revolution, ed. Jean-Francois Constant and Michel Ducharme, 1st ed. (Toronto: University of Toronto Press, 2009), 176-200; James T. Kloppenberg, "Nancy Cohen. The Reconstruction of American Liberalism, 1865-1914," The American Historical Review 108 (2003): 843-844.
} 
least the Great Powers; and second, mutual respect for national interests. As Stanley Hoffman has noted, liberal understandings of sovereignty were revolutionary because they were always understood as part of a larger cosmopolitan struggle to globalize constitutional-representative democracy, and to emancipate "domestic" populations from undue state intervention into individual lives, public opinion, and commerce. ${ }^{8}$ In Hoffman's words, "the international dimension of liberalism was never an afterthought," but rather one side of an evolving coin, such that "the constraints put on government at home" were expected to "expand into constraints on state power abroad." The revolutionary potential of liberalism lay first in the fact that it rested sovereignty at the level of the individual and was consistently focused on marginalizing or restraining the power of the state. But in developing cosmopolitan standards and norms for self-government, liberalism was also revolutionary because it was fundamentally and correlatively concerned with how to apply itself across the globe. ${ }^{9}$

And yet, despite liberalism's limiting of the state and privileging of the individual-as-sovereign, the state remains integral to understanding the history of liberal-internationalism. Understanding this means going somewhat against the grain of liberalism's own self-conception. Historically, liberalism has constructed itself as an anti-despotic form of government, posing the

\footnotetext{
${ }^{8}$ Hoffman, "The Crisis of Liberal Internationalism," 161.

${ }^{9}$ Anderson is helpful on this point, noting that the liberalism that came out of the French and American revolutions imagined itself as part of globally emancipatory project anchored to a "patriotism" that was neither narrowly/ethnically nationalistic, but constituent of an international order where nationism and internationalism were mutually reinforcing. Anderson, "Internationalism: A Breviary," 11-13.
} 
principles of self-governance and global trade as challenges to authoritarian rule because they defy the twin Westphalian notions of the state's monopoly on politics and its right to rule a domestic population as it chooses. ${ }^{10}$ While the distinction between liberal and despotic state forms is real, it is also an effect and strategy that have been integral to liberalism's image as a socio-political ontology with an exceptionally cosmopolitan capacity, best suited to prescribe how to order the world into an international system. The representation of the liberal state as anti-despotic-as the state-form best situated to maximize and eliminate undue intervention in individual libertymust be treated as a strategy used by particular interests to demonstrate the benefits of certain powers (be they state-centered, civic, or cultural) to local and foreign populations. ${ }^{11}$ The marginalization of the state is never absolute, yet the promise of it, and the presentation of a society as exceptionally stateless, is a key strategy of governing in liberal society.

William Novak has called this the "myth of the weak American state": the artificial but still informative idea that America developed out of the historical struggle for "political liberty, emancipation from bondage, the rise of civil, economic, and social rights," situating "property, contract, and freedom of speech, press, and association form the constitutional backbone of a free market, a vigorous civil society, and a democratic polity." As Novak notes,

\footnotetext{
${ }^{10}$ Charles Tilly, "The Time of States," in Stories, Identities, and Political Change (New York: Rowman \& Littlefield Publishers, 2003), 3.

${ }^{11}$ Gilles Deleuze, Foucault, trans. Sean Hand, (New York: Continumm Press, 2006), 45.
} 
while the despotic power of the American state (until recent times) might have been limited, the scale and scope of its infrastructural power is and always has been extensive. From the founding of the first national governing institutions to the conquest of western lands; from the creation of a vast public infrastructure for the promotion of commerce to the construction of a powerful defense and military establishment; from the expansion of governmental powers of police, regulation, administration, and redistribution to the invention of new ways of policing citizens, aliens, races, morals, and gender relations in the production of national culture, the infrastructural power of the American state seems at times boundless, even borderless, as American legal, corporate, economic, and cultural forms spread across the globe. It is this power-infrastructural powerthat renders commentary about American state weakness or statelessness unintelligible. And it raises the intriguing interpretive possibility that the very anti-despotic organization of the American state might actually increase its infrastructural capacity.

Novak proposes that the "models of state theory forged amid the constant threat of centralized despotism" are problematic for our own time, and complicate the challenge of "apprehending the new forms of distended power that predominate in twenty-first-century global political economy." In their place, he employs Michael Mann's distinction between "despotic state power" and "infrastructural power," the former referring to the capacity of state elites to rule, unchecked by other centers of power or by civil society, and the latter to the positive capacity of the state to "penetrate civil society" and implement policies throughout a given territory. ${ }^{12}$ Mann's distinction is helpful to understanding the expansion of American administrative capacities

\footnotetext{
${ }^{12}$ William J. Novak, "The Myth of the Weak American State," The American Historical Review 113 (2008): 752-772. Michael Mann, "The Autonomous Power of the State: Its Origins, Mechanisms and Results," European Journal of Sociology / Archives Européennes De Sociologie 25 (1984):185-213.
} 
in the context of a political culture nominally devoted to the peculiarities of the liberal state.

Building on Novak's insight that anti-despotic states are by no means "weak", this work treats the liberal state as a real force, but one that cannot be understood as a fixed set of apparatuses (military, bureaucratic, executive, judicial) exerting a distinct will or interest. Rather, the state is an effect of:

(i) representing certain interests as synonymous with the state or the will of a nation; and

(ii) the expulsion of interests deemed external to the state, to other constructed spheres such as "society" or "the civic sphere".

The interests allowed to remain in and of the state are portrayed as inherently and necessarily embedded in its capacities, but this obscures that the state is itself an effect of the very discursive compartmentalization that allows us to talk about society, the civic sphere, the social, the private, and so forth, as distinct, if often overlapping, spheres that border on but remain separate from the state. These borders are always contested, in battles that will be familiar to the contemporary reader: debates over the nationalization of certain industries, fears over the linkages between the military, state, and industry (who owns, produces and controls what), resistance to and promotion of privacy legislation, and tensions over which civic institutions should influence politics and which should not. There is no way to treat state-society borders as 
though they have been or will be solidified once and for all. Yet the state still is something, at any given moment.

Treating it as an effect makes acknowledging the last point possible, but it means attention must be given to how the state is historically constituted out of larger, shifting orders of knowledge about how to mitigate the tensions between the constituent spheres deemed external to the state. The liberal state was not only a political reaction to the forces of imperialism and monarchy; it was also the effect of a deeper shift in mentality about where the authority to govern ought to rest and who was qualified to direct this new order. This brings us back to the problem of liberal internationalism. As the following chapters explore, the tension between liberalism's cosmopolitan aspirations and pretenses, on the one hand, and its embodiment or "articulation" as a nation-state, on the other, have plagued American social scientists throughout the nineteenth and twentieth centuries. The precise, ideal form of a state capable of overcoming this tension between the cosmopolitan and the provincial has never been settled at the level of the state. And, understood as governmental conduct connecting states and nations together, the structure of the international remains as unsettled as the contested state forms it is supposed to circumscribe. Therefore, this work proposes that by also treating internationalism as an effect and instrument of liberal governmentality, it becomes apparent that liberal internationalism coheres around a sustained preoccupation with the dispersal of power away from "despotic state" mechanisms, into infrastructures that safeguard popular 
sovereignty. However, for an America still recovering from a devastating Civil War (which facilitated unprecedented state-centralization, the apparent victory of liberal-capitalism over rival political-economic systems, and an increasingly complex national society), the questions of how to capture the popular will, and who was best able to articulate its expression, were far from settled.

The rise of new social science disciplines in the late nineteenth and early twentieth centuries was very much a reaction to this question of governance. This is evident in the period debates over sovereignty, loaning historical weight to Mitchell Dean's contention that sovereignty is "always an open question, a matter of historical, political, linguistic and symbolic construction and contestation." 13 To balance liberalism's tense relationship with state sovereignty-its cosmopolitan vision of universal self-governing individualism on the one hand, and its lingering provincial attachment to the nation-state, on the other-we will see that American social scientists often rationalized their right to local power by placing their work at the center of social governance, offering their profession and practices as a pilot that could navigate the governance of the nation-states in an international system. Of course, as subsequent chapters show, the proper foundations of social scientific knowledge were highly contested; a great amount of thought was given to its proper relationship to the nation-state. But due to the lingering power of the state and its apparatuses, as well as the force of the many non-

\footnotetext{
${ }^{13}$ Mitchell Dean, Governing Societies (New York: Open University Press, 2007), 141.
} 
state structures meant to enhance or check the state's power, any expert hoping to increase its own prestige and power with a nationalistic public had to present American's with a worldview that resonated with pre-existing prejudices, beliefs and values about the state-which consistently meant universalizing the divisions between state and society, public and private, real and ideal, that America's political and social elite enacted in their own lives.

\section{Liberal Social Sciences in America}

Histories of the social sciences in America have largely focused on their national development. They broadly agree that liberalism was integral to their particular form in that nation. This is not to say that American social science was exclusively or exceptionally liberal. Dorothy Ross has convincingly shown that such a view misses the complex of protestant, republican and liberal ideas that were also integrally influential to their development in the late eighteenth and early nineteenth centuries. ${ }^{14}$ My work is less concerned with the intellectual origins of social science or social scientific theory and more concerned with how the "social sciences" emerged as epistemologically organized, ontologically autonomous bodies of knowledge within particular networks of power from the late nineteenth and early twentieth centuries. One historical sociologist has argued in his study of British social science that, "in the early nineteenth century, social science did

\footnotetext{
${ }^{14}$ Dorothy Ross, The Origins of American Social Science (Cambridge: Cambridge University Press, 1991).
} 
not exist, neither as a domain of knowledge nor even as a set of defined practices. There were various activities being done that would eventually be done by social scientists but these activities were not aggregated into systematic sets of tasks."15 While certain knowledge and constituent methods can be said to have moved into what would later become the "social sciences," and there were certainly different trajectories for the British and American scenes, this periodization holds constant for both English-speaking sides of the Atlantic. ${ }^{16}$

This narrative might seem as though it rests on a semantic distinction. One could easily point to pre-Civil War works that actually use the term social science, or note that because sociology and political economy existed well before the later nineteenth century there is proof that nascent forms of social science did exist. My work does not reject the possibility of an intellectual continuity between early methodological innovations (e.g. statistics) and the disciplines of sociology, economics, political science, and international relations and, to a lesser extent, history, anthropology, and psychology as we know them today. The plurality of meanings for "social science" might present a problem. But, to borrow a defense from a sociologist of state

\footnotetext{
${ }^{15}$ Nadav Gabay, "The Political Origins of Social Science: British Parliament and the Emergence of Scientific Policy Making, 1803-1857," (Ph.D. diss., University of California San Diego, 2007). Also see Andrew Abbott, Time Matters (Chicago, University of Chicago Press, 2001), 15.

${ }^{16}$ For a work that directly addresses the unique institutional-historical developments of "professional" social sciences see, Philip Abrams, The Origins of British Sociology, 1834-1914 (Chicago: University of Chicago Press, 1968). See also Michael J. Lacey and Mary O. Furner, The State and Social Investigation in Britain and the United States (New York: Cambridge University Press, 2004); and Theodore M. Porter and Dorothy Ross, The Cambridge History of Science, Volume 7: The Modern Social Sciences (Cambridge University Press, 2003).
} 
formation, "in historical epistemology, one distinguishes words from concepts in that the latter 'make a difference' in theoretical discourse." Or, as Foucault put it, a concept "must give access to a structure of intelligibility."17 The construction of the social sciences cannot be understood apart from the networks of power that agents lived in and had to navigate, shaping the disciplinary boundaries and epistemic communities of what was and is recognized as social science.

There is a real danger of Whiggish anachronism in taking contemporary notions of what social science is as a starting point, thus focusing on academic, disciplinary forms as recognizable in today's universities and developing an account that culminates in contemporary, preconceived alignments. There are constantly rivaling ways of knowing the social world, shaped by a multitude of discourses that shape and re-shape the ontology and heuristics of social science. However, the concern here is not so much with the evolution of the social sciences as diverse and individual disciplinary bodies. Instead, I am interested in two related threads. The first is showing how knowledge became social science using certain methods, ontologies and practices for understanding social, political, economic and historical fields. The second is showing how this process rationalized certain conducts and practices as imperative to the modern, political-economical management of society.

\footnotetext{
${ }^{17}$ Bruce Curtis, "Foucault on Governmentality and Population: The Impossible Discovery," The Canadian Journal of Sociology / Cahiers Canadiens De Sociologie 27 (2002): 505-533.
} 
Specific to this rationalization was the adaptation of new institutional forms and knowledge to a concept of the world-as-international, a concept that itself grew out of liberalism's cosmopolitan aspirations. For historians of social science, the crisis and reconstruction of liberalism in the Gilded Age and Progressive Era provides the major backdrop for understanding the development of the social sciences. While periodization sometimes differs, works on the history of American social science have noted that the institutional emergence and evolution of the social sciences-whether in the American Social Science Association (ASSA), founded in 1865, or in later, smaller professional associations-was both a symptom of and a prescription for a crisis in American liberalism that threatened classical, laissez faire variants and helped push it towards a more reform-oriented, interventionist social and political ideology..$^{18}$

Of course, there remain important historiographical disagreements about liberalism in American history. For example, there is debate over the benevolence or malevolence of a socio-political order that relies on social

${ }^{18}$ The historiography of the social sciences in America has long been preoccupied with the primary formative influence and integrative capacity of liberalism. Morton White in his Social Thought in America: The Revolt Against Formalism with a New Preface and an Epilogue (Boston: Beacon Press, 1969), argued that early social scientists in the US show that the "kinship among some of our most distinctive intellectual currents...form the distinctive liberal Weltanschauung of twentieth century America." It is not a coincidence that Eric Foner, when trying to explain the reconsolidation and reconstruction of Northern liberalism, turned to the ASSA as an archetypal liberal reform body. See: Eric Foner, Reconstruction: America's Unfinished Revolution, 1863-1877 (New York: Harper Perennial Modern Classics, 2002); Thomas L. Haskell, The Emergence of Professional Social Science: The American Social Science Association and the Nineteenth-Century Crisis of Authority (Baltimore: Johns Hopkins University Press, 2000); Mary O. Furner, Advocacy and Objectivity: A Crisis in the Professionalization of American Social Science, 1865-1905 (New York: Transaction Publishers, 2010). Thomas Bender, Intellect and Public Life: Essays on the Social History of Academic Intellectuals in the United States (The Johns Hopkins University Press, 1997); Nancy Cohen, The Reconstruction of American Liberalism, 1865-1914 (Chapel Hill: University of North Carolina Press, 2001). 
scientific, administrative expertise built upon a liberal political ontology of the

world. There is also divergence over the amoebic properties of liberalism, or what Gary Gerstle has called its "protean character," as a political ontology that can circumscribe rival political modes and effectively mitigate modern problems without abandoning a commitment to certain core liberal principles. ${ }^{19}$ This thesis is no more interested in trying to present a universal definition for liberalism than one for social science or internationalism, nor does it claim to explore exhaustively how existing literature has treated liberalism as it relates to social science and internationalism. For the purposes of this work, suffice it to say that extant intellectual and political histories continue to argue over just how essential certain principles or ideologies (for example, corporate capitalism, the individual, equality, majoritarianism, civic virtue) are to American liberalism(s), and what of these made social science work so well within, to borrow a term from Canadian historiography, America's "liberal order framework". ${ }^{20}$ Historians broadly agree, however, that American social science developed a distinctive disciplinary and

\footnotetext{
${ }^{19}$ Gary Gerstle, "The Protean Character of American Liberalism," The American Historical Review 99 (1994): 1043-1073. This view of liberalism is curiously close to that developed by Michael Hardt and Antonio Negri in their works Empire and Multitude, where they outline the liberal-constitutional democracy's impressive capacity to circumscribe and integrate dissent into a biopolitical regime they call "Empire," Michael Hardt and Antonio Negri, Empire (Cambridge: Harvard University Press, 2001).

${ }^{20}$ Ian McKay, "The Liberal Order Framework: A Prospectus for a Reconnaissance of Canadian History," Canadian Historical Review 4 (2000), 617-651. The debate in Canadian historiography around the efficacy of a viewing Canadian history and the formation of the state as the product of a liberal project speaks to the central debates in American political and intellectual history, on the proper characteristics (which McKay identifies as marked by a belief in the 'possessive individual') that define a liberal political or cultural order as such. As Bruce Curtis has noted in a recent review of McKay's work, echoing James Kloppenberg's criticisms of Cohen in the American scene, the terrain of liberal discourse has constantly reconfigured the conceptualization of the nature of self-possession, adapting to changing social networks and technologies of various contemporary environment. For Kloppenberg's review of Cohen see, Kloppenberg, "Nancy Cohen. The Reconstruction of American Liberalism, 1865-1914."
} 
heuristic form in large part because of a dominant belief that liberalism was best able to balance the restive forces of modernity with the demand for progress and universal liberty.

\section{Liberal Social Sciences and American Exceptionalism}

Even those works that argue that the uniqueness of America's liberal experience have been exaggerated, such as Dorothy Ross's Origins of American Social Science, recognize the important directive forces exerted by nationalistic liberalism on social science. Ross's thesis deserves some quick attention here because it is referenced throughout much of what follows. Her landmark study demonstrated how American social sciences owe their "distinctive character" not only to liberalism, but also to "an involvement with the national ideology of American exceptionalism." Exceptionalism, the notion that America occupies an exceptional place outside the forces of history that effect other societies because of its unique republican government and economic opportunity, was built on and sustained by continually drawing on an "intersection of protestant, republican, and liberal ideas around the idea of America." ${ }^{21}$ Importantly, Ross argues, by the turn of the century, a thoroughly "liberal revisionism" of exceptionalism developed with the election of President McKinley in 1896 and the end of the depression

\footnotetext{
${ }^{21}$ Dorothy Ross, Origins, $x v-x v i i, 143-149,343$. Ian Tyrell, "American Exceptionalism in an Age of International History," The American Historical Review 96 (1991): 1031-1055; David Keith Adams and Cornelis A. van Minnen, Reflections on American Exceptionalism (Edinburgh: Edinburgh University Press, 1994); John Torpey, "The Problem of American Exceptionalism Revisited," Journal of Classical Sociology 9 (2009): 143-168.
} 
in 1897. It was then that the strains of industrialization-which had implicitly raised questions about the ability of the United States to escape from the historical processes afflicting other states-appeared to abate, and a more thoroughly liberal exceptionalism developed in social science around the Progressive movement problematics of corporate monopolies, trusts, class conflict, income taxation, and social welfare reforms. Ross is careful to note that these newly-framed social and labour problems placed social scientists in a critical role, legitimating the view that a harmonious liberal society was possible and imperative to America's future prosperity. This alone helps put in context Lippmann's optimism about the role of a universal discipline and administrative class guiding democracy. Like the first generation of nationalminded social scientific reformers, who "thought of themselves as elite guardians of the American Republic" and made reform central to social science's identity, the institutionalization of disciplines and their professionalization throughout the Progressive Era created an environment where change at the political level demanded that one continue to place "the old principles of American exceptionalism on unassailable scientific ground," and portray America as truly apart from the historical forces that had created "the prolonged class conflict of Europe and the necessity for radical change."22

\section{Liberal Exceptionalism}

\footnotetext{
${ }^{22}$ Ross, Origins, xviii, 25, 54, 64, 96, 476
} 
Ross's idea that the social sciences are characterized by their interaction with the distinct national ideology of American exceptionalism is important, and is carried forward at various points throughout this work. American exceptionalism exerted a consistent and influential force on the American social sciences' framing of the nation-state as central both to their own disciplinary identity and to the problematics that animated them. The nation-state was not simply a container in which social sciences developed particular characteristics; it was part of a socio-political identity and power structure that had an effect on the development of methods, ontologies, and boundaries of the disciplines. This thesis accepts these foundational ideas from Ross's work, but it also builds on them, arguing that American exceptionalism in the social sciences was itself in constant tension and dialogue with another equally powerful exceptionalism: liberal exceptionalism.

As the introduction touched on, "liberal exceptionalism" is the ever more present assumption that liberalism has a distinct monopoly on liberty because of its anti-imperialism, its privileging of the voluntaristic individual, and its distrust of state institutions. ${ }^{23}$ This second exceptionalism has sometimes been a countervailing and other times a complementary discourse

\footnotetext{
${ }^{23}$ Go, "The Provinciality of American Empire," 74-108. This is a modification of Go's notion that "liberal exceptionalism" was the strand that "admits that the United States has been an empire, but insists that the empire has been unique. While European empires were tyrannical and exploitative, American empire has been beneficent and selfless." Few of the early liberal exceptionalists that emerged in this period were willing to conceive that they were engaged in empire building. Rather, the very concept of anti-imperialism provided the rationale for much of the intervention from 1895 to World War One, replacing the language of empire with equally squishy concepts like Civilization or Liberty or Democracy.
} 
alongside American exceptionalism. Liberal internationalists in the social sciences had constantly to balance the forces of national exceptionalism with liberalism's faith in its capacity to offer a totalizing, cosmopolitan knowledge built around the sovereign individual. The social sciences, I argue here, formed the body(ies) of knowledge that rationalized this tension, by representing and shaping dominant understandings of the international to reconcile both these exceptionalisms.

\section{The Social Sciences as International because they are Transnational}

Recent work on the international history of the social sciences provides some important hints about the importance of liberal exceptionalism for the formation of American social science. Tying American innovations of the idea of liberal nation-states to a "global context," Thomas Bender's $A$ Nation Among Nations has shown that understanding the history of the social sciences demands understanding them as part of a larger global cultural exchange of ideas that created political iterations of progressivism and liberalism. throughout the world. A growing body of global history has treated the social sciences as a key indicator of what Daniel Rodgers called, in the transatlantic context, "conversation about social policy, reform networks, and regulatory and welfare policies enacted between the 1880 s and the 1920s."24 Bender has

\footnotetext{
${ }^{24}$ Thomas Bender, "The Industrial World and the Transformation of Liberalism" in A Nation Among Nations: America's Place in World History, (New York: Hill \& Wang, 2006), 248. Also see Charles Bright and Michael Geyer, "Where in the World is America? The History of the United States in the Global age," in Thomas Bender, ed. Rethinking American history in a Global Age, (Berkeley: University of Califomia
} 
proposed that different countries, connected by these global networks of ideas and governmental innovations, "prompted the development of new academic social-science disciplines that spread from Germany and France to all the industrial societies in the world, offering new capacities for understanding the "social question" that encouraged and made possible a novel political response to the social transformations of the era-a social politics."25

The standardization of solutions to the "social question," via the sharing of ideas across borders, did not lead to identical results; different institutions and social scientific fields emerged in different local contexts. But, as existing works have shown, the interconnectedness of national and political histories, read alongside the history of the social sciences, reveals what can only be characterized as a global liberal movement engaged in a shared struggle with modernity. For Bender, "the heart of the matter is that the search for solutions to social problems caused by industrialization was an intense international effort involving many countries all over the world."26 American social

Press, 2002), 63-100. For more on Ross's critique of exceptionalism see Ross, "Grand Narrative in American Historical Writing: From Romance to Uncertainty," American Historical Review 100 (1995). For more on the multivariate nature of exceptionalism in American history see, Daniel T. Rodgers, "American Exceptionalism Revisited," Raritan Review 24 (2004): 21-48; "Exceptionalism," eds., Anthony Molho and Gordon Wood, Imagined histories: American Historians Interpret the Past, (Princeton: Princeton University Press, 1998); Atlantic Crossings: Social Politics in a Progressive Age (Cambridge: Harvard University, 1998); James Kloppenberg. Uncertain Victory: Social Democracy and Progressivism in European and American Thought, 1870-1920 (New York: Oxford University Press, 1986).

25 Bender, Nation Among Nations, 248.

${ }^{26}$ Rodgers, Atlantic Crossings, 256. Thomas Bender cautions that while historians should be wary of exceptionalist claims, it is important not to deny the existence of difference in state forms, distinctive political cultures and political organizations. This supplements Daniel Rodgers earlier contention that American exceptionalism meant more than difference, signalling a sense of exceptionality to the historical rule of development followed by most other states. The US did not simply see itself as different, but as 
scientists were not alone in wrestling with the social question in the late $19^{\text {th }}$ century, which could lead us to conclude that the framing of the social problem as such, and the idea that it could be managed by a new, more "social liberalism," was a boon for the social sciences that inserted their knowledge of general social principles at the core of administrative democracy. ${ }^{27}$ But if the new "social liberalism" of the late nineteenth century was framed as particularly, self-consciously international, it should also follow that the social sciences were not only reacting to an expanding global consciousness, but were increasingly ordering the world as an international space that reflected that global consciousness.

The centrality of internationalism as a construct calls up one final historiographical concern. Over the last decade, much emphasis has been placed on the power of transnational histories to situate social, institutional, ideational and practical networks within larger global flows outside a statecentric historical focus. Such histories, like international histories, are seen as a way of displacing American exceptionalism by showing how American intellectuals and reformers, influenced by many of the same forces as their global counterparts, purposefully built institutions and capacities that bypass the nation-state. In Europe and many Latin American countries or former American protectorates, where the bleed between national social scientific

outside of the universal trajectory of history itself. And, Rodgers continues, implicit in all claims of exceptionalism is a prior understanding of all other histories that constitute the supposed norm of this trajectory. That is, American historians only make claims about themselves based on juxtapositions with claims about (mostly) Europe.

27 Ibid., 256-257, 288. 
practices has been more apparent and the case for insulated national traditions harder to make, historians of the social sciences have pushed the importance of situating the social sciences in a transnational framework. ${ }^{28}$

On this score, I am in complete agreement. It is imperative to see the development of the social sciences as transnational to liberate ourselves from clumsy universal concepts like "national interests," or the idea that the nationstate's practices and thought were hermetically sealed off from outside influence. However, in displacing the nation-state as a container for our historical voir, historians must be careful not to treat historical agents' efforts to move around states, through actions in non-state or civic spheres, as proof of their non-participation in the formation of states. As Pierre-Yves Saunier argues, "the transnational perspective should not become the background narrative for positive or negative assessments of globalisation, the handmaiden for a post national world."29 Historical actors interested in practices not explicitly concerned with the nation-state, or who tried to bypass or were marginalized by the nation-state, can still have been active in constructing the methods and knowledge that were integral to particular state forms. In some instances, as this work's discussion of the variants of liberal

\footnotetext{
28 Johan Heilbron, Nicolas Guilhot, Laurent Jeanpierre, "Toward a Transnational History of the Social Sciences," Journal of the History of the Behavioral Sciences 44 (2008): 146-160. For slightly, older example, see Johan Heilbron, "The Rise of the Social Sciences in France," European Jounral of Social Sciences 42 (2004): 145-157. For an example of a work that treats the international as a normative space in which the social sciences act see Mauricio Tenorio Trillo, "Stereophonic Scientific Modernisms: Social Science Between Mexico and the United States, 1880s-1930s," The Journal of American History 86 (1999): 1156-1187.

${ }^{29}$ Pierre-Yves Saunier, "Learning by Doing: Notes About the Making of the Palgrave Dictionary of Transnational History," Journal of Modern European History 6 (2008): 163.
} 
internationalism will show, the state's marginalization is imperative to the presentation of civic or social phenomena as transnational, and imperative to the social science's disciplinary expertise on the latter. Moreover, social scientists consistently imagined the marginalization of the state and its apparatuses as a crucial part of the development of a truly liberal international governmental system, which looked much the same as the small scale liberalstates liberal internationalism promised eventually to subvert.

The example of Randolph Bourne, the first American to call publicly for transnationalism in 1916, illustrates this point well. Taking the concept from his studies in Germany, Bourne positioned the transnational as a way to expand America's national identity to include a multitude of nations, developing what he called "a new consciousness of what America meant...as a citizenship in the world." For Bourne, as with most liberal internationalists, transnationalism was a way of de-essentializing the ethno-cultural foundations of the nation-state, attacking those who protected the homogeneous racial and territorialized space that he derisively referred to as the "German realistic interpretation" of the state as uni-national. ${ }^{30}$ Bourne imagined America as

\footnotetext{
${ }^{30}$ Randolph Boume, "Trans-National America," Atlantic Monthly, 118 (1916): 86-97. Emphasis added. For an older work on the promises and dilemmas of transnational approaches see Joseph S. Nye and Robert O. Keohane, "Transnational Relations and World Politics: An Introduction," International Organization 25, no. 3 (July 1, 1971): 329-349. For a newer and strong overview of this literature from a political science background see, Sidney Tarrow, "Transnational Politics: Contention and Institutions in International Politics," Annual Review of Political Science 4, no. 1 (June 2001): 1-20. This, perhaps, explains the uncomfortably slippery conceptual terrain between "the international" and "trans-national" in historical literature. Too often is trans-national assumed to occupy a non-state, social sphere while the international is taken to represent state-to-state or nation-to-nation relations and institutional forms. The problem with this concept of the transnational is that it assumes that actions that are carried out in the global sphere are not done with an eye to presenting or representing a new international nor national form; it assumes an absence of consciousness about governance and an awareness of its very real power in nation-states.
} 
unique (the exceptionalism of this is contestable) because it proved that a peaceful settling of nationalities was possible if the power of the "integrated State" was marginalized. "In a world which has dreamed of internationalism," Bourne noted,

we find that we have all unawares been building up the first international nation. The voices which have cried for a tight and jealous nationalism of the European pattern are failing. From that ideal, however valiantly and disinterestedly it has been set for us, time and tendency have moved us further and further away. What we have achieved has been rather a cosmopolitan federation of national colonies, of foreign cultures, from whom the sting of devastating competition has been removed. America is already the world-federation in miniature...Here, notwithstanding our tragic failures of adjustment, the outlines are already too clear not to give us a new vision and a new-orientation of the American mind in the world. ${ }^{31}$

Bourne envisioned the dissolution of smaller nations into one large one, but at the level of society - something that, in Bourne's mind as in the minds of many others at the time, was (and should have been) separate from the state. The making of one large world society was to involve the abolition of the nationstate but not the abolition of nationalities, and in place of the former would be an international humanity. A humanistic internationalism was going to be the effect of a new governmentality, one built on non-essential cosmopolitan principles.

Regardless of his intentions, and even as an outlier concerned with but not officially involved in the formation of the social sciences, Bourne's idea of the international as a sphere built on cosmopolitan-transnational knowledge

\footnotetext{
${ }^{31}$ Bourne, "Trans-National America." 88.
} 
and practices was the type of thinking that provided a perfect opening into which the professionalizing social sciences could and did insert themselves. Indeed, they were able to draw on the discursive linkage between cosmopolitanism and civic institutions, particularly the universities, in Bourne's ideas of the American of the "younger generation," accepting and carrying forward from "his colleges...the study of modern history and politics, the modern literatures, economic geography, the privilege of a cosmopolitan outlook such as the people of no other nation of to-day in Europe can possibly secure. ${ }^{32}$ Exploiting this common linkage in Bourne's and others' thoughts on transnationalism, social scientists would position themselves as the transnational experts with cosmopolitan knowlege who could establish the guideposts and design the machinery to carry a nation to its post-national, international culmination. But where Bourne imagined a governing role for "humanity", many social scientists in the early twentieth-century saw a way to make the diffusion of the state through civic institutions look like its absence.

Rather than playing to this sleight of hand, the remainder of this thesis demonstrates how American liberal social scientists have often used debates around and concepts of the international as a tool for performing their cosmopolitanism and transnationalism, which reinforced their unique capacity to bridge the gap between the polis and demos without falling under the influence of either the state or society. By standing between, but outside of these two spheres, the state-society distinction became integral to the ${ }^{32}$ Ibid., 88-89. 
development of social scientists' authority. As I will show, many would view their discipline as informed by the nation-state or vice versa but few would contend that internationalism was itself a product of historical and social networks of power that were themselves deeply invested in the existence of a particular state.

Ignoring the historical and sociological development of the concept of internationalism, pulling it out of particular circumstances, allows a view of social science as capable of totalizing and universalizing, and shelters internationalism from the same critical attention now being paid to the nationstate. Moreover, to assume the regimes of international governance advocated by many social scientists are international because they are not wed directly to state apparatuses such as the bureaucracy, military or other mechanisms of recognizably state-centered imperial intervention, perpetuates a view of the state and society as distinct spheres. Not only did this ideal of a definitive separation of state and society allow social scientists to portray their work as a guarded border between the state and society that assured that the powers to govern were not wrested by the state. The state/society divide, proposed as something best defined and articulated by those who claim to be, and are accepted as, "non-state" (legal associations, social science associations, social reform organs, labor policy internationals or think-tanks), creates a tautology in our understanding of governance: the success of non-state social scientific knowledge and institutions serving as 
mediators between state and society is taken as proof that America was an exceptionally liberal and, therefore, stateless society.

\section{Civic and Social Internationalism: a final note on terms}

This work traces two dominant threads of liberal internationalism in America. The first is civic internationalism, which is built around the concept of civic institutions carrying the liberal emphasis on the separation of state and society out into the world and formalizing as an international. Civic internationalism underwent a number of shifts in emphasis on what kinds of knowledge and what experts could best access that knowledge, but it consistently anchored itself to a view of the nation as an organic solidarity that was best articulated by particular civic infrastructure. So, while the emphasis on particular institutions and the cultural and historical foundations of these institutions would be rationalized differently over time, the legitimation of the state via adoption of methods, deferral to expertise, or the adoption of legislation that took on particular rationalities, was integral to this internationalism.

The second form of liberal internationalism that this work traces is social or, alternately, social scientific internationalism. Social internationalism remained much less anchored to the legitimation provided by existing civic institutions and was much more skeptical of the importance of the state in preserving liberalism on a global scale. For this reason, social internationalists can largely be differentiated from their civic counterparts 
because of the importance they placed on the social scientific expert whose principles were more fundamental to humanity than those expressed in civic institutions. Importantly, social internationalists saw an important role for the nation-state in projecting liberalism outward. While the idea of the state as a temporary state-form would legitimate state imperialism for some, for others it created a deep ambivalence around the use and harnessing of its power. For this reason, social internationalists still stressed the importance of a mediator between society and the state, and often formed new civic organizations. However, unlike those of the civic internationalists, these civic organs were treated as mechanisms for acting on social scientific principles and knowledge that generally bypassed the nation-state and imagined society as already internationally interconnected. There were moments when the civic emphasis on existing institutions and the protection of the nation-state as an end bled into social internationalism. And there were moments when social internationalism's emphasis on the social scientific knowledge and experts, over and above legalism or diplomacy, flowed back into civic internationalism. But it is precisely in the dialectic between these two forms of internationalism that liberal governmentality adapts, circumscribes and thrives.

This work does not use the rather underexplored concept of progressive internationalism. Thomas Knock, building on earlier attempts to salvage Wilson from New Left and Realist interpretations of his presidency, took this term to emphasize Wilson's political internationalism, restoring his 
leftist credentials by showing how his ideas of collective security, selfdetermination, and political cooperation were influenced by socialists and left liberals who were part of a progressive international movement. ${ }^{33}$ Unfortunately, this concept seems clumsy in its use of conservative versus progressive internationalism, relying on Wilson's biography to position him on a limited political spectrum (left-to-right) that is itself one part of a vastly complicated epistemological terrain. Carsten Holbraad has argued that as the institutions and networks that constitute the international may vary with different concepts of the international, "the aim may be to maintain or develop the existing order of international society, or to change that order and transform international society in some way or other." While Holbraad presents a basic distinction between conservative and progressive internationalisms, he cautions that, even the transgressive aims of progressive internationalists are necessarily anchored to "the existing society of nations." 34 For this reason, I have chosen not to study internationalism in political but in institutional terms, focusing on those institutions and knowledges that were treated as capable of bridging the gap between societ(ies) and state(s).

In so doing, I engage with some of diplomatic history's central dichotomies-the real/ideal, agent/structure, interest/interpretation,

\footnotetext{
${ }^{33}$ For more on this historiographical distinction see David Steigerwald, "The Reclamation of Woodrow Wilson," Diplomatic History 23 (1999): 79-99.

${ }^{34}$ Carsten Holbraad, Internationalism and Nationalism in European Political Thought, 1 st ed. (New York: Palgrave Macmillan, 2003), 1-2.
} 
progressive/conservative, international/national, foreign/ domestic, state/society and the like-but I do not adopt them as analytical principles. This is not to deny their reality, power, and importance; quite the contrary. By showing how these dichotomies became central to the thinking, practices and institutions that have been used to order global society into an international, this work shows that such distinctions have very real effects. It merely maintains a sense of irony about the division between the state and society, and the contents of each. It asserts that what we think and claim to know about various spheres of life, while often assumed to be trans-historical or essential, is constantly changing; our claims to knowledge have real effects, but they are not foundational. Accordingly, this study uses the emergence of several institutions and disciplines at the base of American liberal internationalism to show that its representation is intricately dependent on making certain forms of knowledge-not least the partitioning of the world into separate spheres-appear self-evident. But rather than engaging with the realism or idealism of particular forms of internationalism, this thesis has two intertwined concerns. First, it seeks always to show the undergirding rationality that allowed historical actors to represent the liberal state-form as the only solution to the global problem of how best to govern states. Second, it is concerned with showing how those who could lay claim to the mantle of social scientific knowledge gained influence in the US by positioning themselves as the mediators best positioned to bridge those dichotomies taken as universal (state/society, foreign/domestic, international/national) 
without being corrupted by or concerned with exerting power. These overarching concerns span the chapters to follow, beginning next with the exploration of such themes in the Gilded Age and Progressive Era. 
Chapter Two: "Sovereignty is only a means:" Social Science, International Law and "The International", 1867-1880

To begin to explore the relational development of the social sciences and liberal internationalism in the US we must first turn to their concurrent rise in the Reconstruction Era and early Gilded Age. The first section of this chapter argues that internationalism was a key conceptual technology for American liberal social scientists who hoped to thrust themselves to the center of governance in the post-bellum state.The social sciences of post-bellum America, I contend, ordered the flexible concept of internationalism around a belief that governance was best guided by formalizing deeper social laws, already apparent to and widely accepted by American reformers, in the apparatuses of the state and its juridicial mechanisms. ${ }^{1}$ Additionally, I argue that the attendant claim that social science provided the best means for directing state and international governance-because it could best elucidate the geographical and popular contours of the democratic-sovereign nationstate-depended on striking a balance between "liberal" and "American exceptionalism." To show this, the second section of this chapter takes a broad look at how social science developed within liberal intellectual circles in the 1860s and 1870s around two particular principles: 1) the belief that social science offered an instrumental and/or non-political position from which to manage national and international affairs through control of social

\footnotetext{
'I borrow the idea of "the international" or internationalism as a "flexible concept" from Timothy Mitchell, "The Limits of the State: Beyond Statist Approaches and Their Critics," The American Political Science Review 85 (1991): 77-96.
} 
laws; and 2) the importance of arriving at social laws apart from or outside the state.

As this chapter concludes, liberal internationalism was not a monolithic concept in Reconstruction and Gilded Age America. Rather, two variant threads are apparent throughout the 1860s and 1870s. As American social scientists tried to balance a nationalistic exceptionalism, intent on preserving the American nation and state, with the universalizing impulse of liberal exceptionalism two competing threads, which I have already outlined as "civic" and "social" internationalism emerged. Importantly, both shared a faith in social science as a method for discerning fixed social laws in order to better govern the nation. But they are definably different on the important question of the permanence of, and role played by, the sovereign nation-state in reaching towards a larger international community.

Chapter One touched on two indispensable points about liberalism and American social science. First, although historians disagree about many of the details, there is an emerging consensus around the idea that rapid industrial modernization brought about a crisis for liberalism in America. ${ }^{2}$ Second, it is

\footnotetext{
${ }^{2}$ When trying to explain the consolidation and reconstruction of Northern liberalism in his study of post Civil-War reconstruction, Eric Foner turns to the ASSA to demonstrate how effectively an "ideology of reform" was institutionalized in a way that "helped crystallize a distinctive and increasingly conservative middle-class consciousness" and imagined an "administered democracy" as integral to the preservation of liberal democracy in America (Eric Foner, Reconstruction, 488-518). Though Thomas Haskell was more sympathetic to the intentions of liberal reformers, Foner's reading echoes Haskell's earlier work that treats the ASSA as a key site for the reconstruction of liberalism around a reform agenda. While Haskell notes that the ASSA's institutional form would falter, in providing a space for deep discussions on civil service, prison, education, and industrial reform, as well as free trade, the generation of reformers in the ASSA helped focus the early identity of American social science, both making the reform of industrial and corporate capitalism its modus operandi, and naturalizing liberal-capitalism as a manageable form of modernity (Thomas L. Haskell, The Emergence of Professional Social Science). Unlike Haskell, Mary
} 
generally accepted that liberalism played a fundamental, formative role in the development and professionalization of social science in the US, as exemplified most clearly in the formation of the American Social Science Association (ASSA) in 1865. And yet, while much attention has been given to the effect of "liberalism" (particularly as a political ideology) on the social sciences, there is only a marginal acknowledgement of the reciprocity between the two. Existing literature does little to help answer the question of where the rise of internationalism fits into the narrative of the social sciences' emergence in the American state at the same historical moment. How do we make sense of the coetaneous rise of the liberal social sciences and a particularly liberal form of internationalism in the United States?

The construction of a concept, and the representation, of internationalism by many American social scientists from 1867-1880 was always bound by certain pre-existing discourses. In fact, as we will see in the story of Joseph lieber and David Dudley Field reveals historical agents who understood and navigated particular constraints, not least the power of

Furner has taken a much less charitable view of the reform-based motives of social scientists, highlighting what she calls the ongoing tension between advocacy and objectivity that characterized the mission of social science. Furner argues that early ASSA "amateurs" who focused on philanthropic, social-welfare reform, constituted the core of social science. But as social science became the disciplines we now recognize as social sciences, the reformatory focus of the ASSA was replaced with a more specialized and allegedly less activist academic rigor. Working from professional associations largely housed in universities in the $1890 \mathrm{~s}$, Furner laments the retreat of social science from the social and public spheres and the ideological streamlining that steered the social sciences professional identity towards a more conservative consensus (see Mary O. Furner, Advocacy and Objectivity); also see Nancy Cohen, The Reconstruction of American Liberalism, where she argues that from the formation of the ASSA onward, the social sciences have been central to controlling and rationalizing administered democratic mechanisms aimed at regulating the worst excesses of corporatism and monopoly, through disinterested and specialized social scientific experts who advised on how best to expand and limit the administrative functions held by the state, underwriting them from a position of disinterest. 
America's exceptional statelessness, but capitalized on these very limitations. As nation-states around the world became increasingly rationalized by modern knowledge, a concept of internationalism that reflected shifting liberal notions of sovereignty was a logical consequence and a convenient arena for demonstrating just how ideal was America's division of state and society. Gilded Age social science then, conceptually and practically, adapted internationalism around the rising authority of social science as a way of balancing the dual pressures for a sovereign and territorially distinct America with the liberal belief in an achievable international system beyond the state. As we will see, internationalism was a key conceptual structure that allowed social scientists to shape the world by representing the elite American distinction between society and state as universal and globally imminent.

\section{Internationalism and Professionalism in Gilded Age America}

Our grounded examination of internationalism as an effect and instrument for social science that underwrote a particular state effect, begins in the so-called Gilded Age. ${ }^{3}$ By the end of Reconstruction, rampant patronism and corruption associated with the Jacksonian spoils system in politics had created a moral panic among liberal elites. At the same time a deeper crisis

\footnotetext{
${ }^{3}$ For the usage of the term Gilded Age and its genealogy see, Richard Schneirov, "Thoughts on Periodizing the Gilded Age: Capital Accumulation, Society, and Politics, 1873-1898," Journal of the Gilded Age and Progressive Era 5 (2006): 189-224; and the very helpful "Forum: Should We Abolish The Gilded Age?" in The Journal of the Gilded Age and Progressive Era 8 (2009), especially Rebecca Edwards, "Politics, Social Movements, and the periodization of US History," 461-473.
} 
of confidence in the wage labour ideology widely championed as the democratic and humane alternative to the South's slave economy came under new scrutiny among the general public. The vast national mobilization of the war had rapidly expanded the administrative capacities of the American state, but it also left a legacy of acceptance of a more centralized administration that brought industry and the state into an open, if unseemly, alliance-that is, open, but far from transparent.

As Ulysses S. Grant's first term as President progressed, an influential group of Whig-liberals grew discontent with the political machines at work in state and federal politics. One Republican lamented that the nation was being run by what seemed more like "Senatorial cabals" than proper governments, wielding immense influence and consolidated power. ${ }^{4}$ Against the looming sense of a crisis in the legitimacy of government and lingering republican concerns over the influence of an increasingly powerful state, Whig-liberals like E.L. Godkin, Frances Amasa Walker, Horace White, David A. Wells, Andrew Dickson White, Daniel Coit Gilman, and politicians such as future President James Garfield emerged as giants of Gilded Age reform. They would make what many scholars agree was a disproportionate footprint on the American cultural and political scene, establishing influential journals such as The Nation, North American Review, the Springfield Republican, and Chicago Tribune, expanding and liberalizing universities and colleges, and establishing the first professional social scientific body in the US, the ASSA. As

\footnotetext{
${ }^{4}$ Foner, Reconstruction, 488.
} 
Eric Foner has argued, the growing prominence of this small group of reformers "reflected the coming of age of an American intelligentsia determined to make its mark on the politics of the Gilded Age."

The rise of these liberal intellectuals in the US was not unique, and can easily be situated as part of a broader, global shift in thinking about government and sovereignty that held up distinctly territorialized nationstates, such as France or Great Britain, as the most successful state form for capturing and containing popular sovereignty. In the US, Radical Republicans who had been the staunchest supporters of the Civil War as a means to abolish slavery, and those liberals who had fought for the purposes of either simply holding together the union or extending the industrial and wage labor system to the South, found shared language with liberal counterparts around the world, all echoing the rhetoric of the 1848 European revolts. As President Lincoln had during the American Civil War, many liberals found "romantic nationalism" a convenient offset to the power of Kings and Empires, arguing that the nation embodied a more realistic expression of sovereignty by resting it with the people. ${ }^{6}$

But for many in the American middle class throughout the Reconstruction Era this idea of popular nationalism was strained as labor unrest and the apparent endemic corruption of party-boss and patronage

\footnotetext{
${ }^{5}$ Ibid, 488-489; For more on this, also see John G. Sproat, The Best Men: Liberal Reformers in the Gilded Age (New York: Oxford University Press, 1968); Stephen Skowronek, Building a New American State, 4246.

${ }^{6}$ Bender, A Nation Among Nations, 178-179.
} 
politics threatened the centrality of their socio-political values as the core of governance. As then-historian Francis Parkman opined, many middle-class Americans felt sandwiched between "an ignorant proletariat and a half-taught plutocracy" that had "risen like spirits of darkness on our social and political horizon."17

As postwar industrialization deepened this alteration of the social landscape, reformers reacted by proposing that the proper expression of sovereignty resided not in a popular-political expression by the nation, but in a scientific class passing scientific legislation and properly guiding the governance of the state. As the political scientist John W. Burgess argued, the "nationalizing of civil liberty" under the protection of the judiciary would sustain a nation-state led by "white-men, whose mission...duty...and right" was "to hold the reins of political power in their own hands for the civilization of the world and the welfare of mankind." 8 Facing a political organization beholden to workers and ethnic constituencies, many liberal and "mugwump" elites balanced a dual impulse to nationalize by building centralized sociocultural mechanisms while displacing an older political machine that would use the centralized state for personal gain and graft, costing industrialists and the country's entrepreneurial middle-class. As Thomas Bender notes of the Gilded Age intellectuals, for this group "the 'State' became 'antonym of the people.' The liberal ideal of rights-carrying individuals was questioned, and

\footnotetext{
${ }^{7}$ Cited in ibid., 179-180.

${ }^{8}$ Ibid., 179.
} 
political theorists argued that the state conferred rights on the people, rather than the people conferring legitimacy on the state."

It could be argued that the American reformers' retreat from popular nationalism is best explained as a just effort to renew the political apparatuses of the democratic state, shaking loose the chains of patronage and corruption by making those apparatuses more scientific or rational. The move to displace political "bosses" and state-circles was no doubt motivated by a desire to check corruption. North-Eastern elites had long resented the graft networks, and the spoils system championed by many Jacksonians, which politicized apparatuses of the state in a way that made them harder to influence and seize without resorting to transparent manipulation of majoritarian rule. And yet, when viewed at a structural level, it is impossible to ignore that the Gilded Age reformers who pared off from the "grand Republican organization" over corruption and patronage in the Federal and local state imagined themselves running the alternative organizational, ideological and interpersonal networks at the core of the state. Even more difficult to ignore is the fact that to redress these local power struggles over the proper division of state and society, these reformers rallied around social scientific methods that portended to claim a universalism that explained society and history not only of their nation, but of the world.

Much has been written on the Gilded Age calls for civil service reform, their mostly failed demands for tariff reforms and free-trade, and their move

\footnotetext{
${ }^{9}$ Ibid. 178-179.
} 
to limit the interventionist capacity of the state by getting government out of the "protective" and "subsidy business." 10 Still more has been written, mostly in a tragic vein, on the ASSA as a site of rising middle-class conservative consciousness around the mantle of reform, a case study of American liberals turning into apologists for free-markets and against labor and fully universal suffrage. The ASSA's work on health, prison, and labor reform reflected a deep faith in classical liberalism that made early social science appear philanthropic and ameliorative but increasingly out of touch with the broad social opinion it claimed to channel. ${ }^{11}$ But presenting social science as integral to maintaining a manageable and safe distance between the state and society had substantial effects not only on the formation of the administrative state, but also on the undergirding rationalization of states. The insertion of social scientific methods and knowledge into state apparatuses altered the liberal horizons of the American state effect, where networks of nationally minded social scientists and influential intellectuals became increasingly central to managing the separation of state and society.

Accordingly, across the US and Western Europe, a shift was underway wherein governance came to increasingly reflect the division in knowledge made by professionals and industrialists throughout the late $18^{\text {th }}$ and early $19^{\text {th }}$ century between their own roles as authorities, on the one hand, and the state, the social, and society, on the other. This division had been, throughout the

\footnotetext{
${ }^{10}$ Furner, Advocacy and Objectivity, 85-95; Robert H. Wiebe, The Search for Order, 1877-1920 (New York: Hill and Wang, 1966), 2-10.

"See especially Cohen, Reconstruction of Liberalism, 261.
} 
$18^{\text {th }}$ and early $19^{\text {th }}$ centuries, integral to a political ideology that rested the authority of governance in the white, male, property-owning individual, thereby rejecting mercantilism and imperialism exerted by the state. For the prodigious institution builders who would form the ASSA in the post-bellum era, professionalism seemed uniquely positioned to take on the authority of governing. Secularized, self-policed and deriving their authority from participating in civic society rather than in the state, it seemed natural that the social sciences would follow the example of lawyers, doctors, and natural scientists who were gamering ever more admiration and power in these countries.

But professionalism also provided a shibboleth, one that liberal reformers like those in the ASSA used to foment a sense of distinction within an organic nation, where the state treated the social stratification that accompanied capitalist free markets as a natural phenomenon, but presented any resulting class-based solidarities as aberrations of the same social system if they did not acknowledge they had an a priori functional role in a America's liberal political economy. As one ASSA member noted in 1871: "While the spirit of class, like the spirit of sectionalism, in certain manifestations, ought to be discouraged and condemned, there can be no question that every class in a nation...has peculiar interests...[and] duties to perform to the State, growing out of its own conditions and relations which cannot be 
misunderstood...without public loss." ${ }^{12}$ The professions offered a liberal bourgeois mental framework that, at least for them, settled the ambivalence left around federalism after the Civil War.

By treating economic "laws" of individualism and contract as synonymous with American nationalism, it was possible to explain the dramatic socio-economic inequality of the post-Civil War era as stratification serving the nation-the distribution of wealth reflecting the stratification of people into classes with varying abilities and interests. While this meant accepting differences in class interests, by seeing differences as functional rather than conflicting, the liberal reformers argued that it was their natural place to manage. As Frances Amasa Walker wrote in one reading of the proper function of various classes, the professional was "the person who investigates the material resources of the country," and "organizes industrial enterprises for the exploitation of those resources," and was not to be confused with one who "superintends and directs labor." ${ }^{13}$ The liberal professional class in the US was not a class of managers; its members fancied themselves much more. Their guidance of the resources and energy of both the nation and industry would assure the most economical management of society and the state, ameliorating the effects of modemization and maintaining America's exceptional place beyond the historical dynamic of class antagonism that plagued European nation-states.

\footnotetext{
12 H.A. Hill, "Relations of Business Men to National Legislation," Journal of Social Science 3 (1871): 148.

${ }^{13}$ Francis Walker, "Industrial Education," Journal of Social Science, 19 (1884): 117-131.
} 
Thus the Gilded Age was, as Mary Furner put it, "an exciting time for professions." Although the classical professions of theology, law, and medicine had long exercised sway in American society, the middle years of the nineteenth century were a time of general de-professionalization. ${ }^{14}$ That trend, however, was reversed in the years during and after the Civil War. By then, the authority of the church was decidedly eroded, particularly in the North, as the state's apparatuses grew, sucking in the old professions of law and medicine directly, vesting them with a new authority independent of the moral authority of the church. Denominational colleges gradually gave way to professional institutions and disciplines concerned with managing society and the state. And new specialized professional knowledge, particularly in the physical and natural sciences, gained institutional momentum in major state centers, not least Washington.

There was a growing desire among emergent social scientists in the 1860 s and 1870 s to harness this current. Accordingly, they sought connections with old professions, which served as "conservators of social authority." 15 But the détente between the church and the old "liberal professions" of law, medicine, and teaching in antebellum America stifled the aspiring, secular social science from achieving a professional prestige like that achieved by the natural sciences. And so, by the late 1860s, Daniel Coit Gilman and others in the ASSA were publicly warning that the old professions were not properly

\footnotetext{
${ }^{14}$ Furner, Advocacy and Objectivity, xi

${ }^{15}$ Ross, The Origins of American Social Science, 37.
} 
disinterested, but had effectively lost their connection to the stream of secularizing, civic society when they became less concerned with the development of the university and the civic virtues of the profession than with the whims of politics and commerce. ${ }^{16}$

Most of those who composed the multi-professional ranks of the ASSAlawyers, doctors, professors, clergy, bureaucrats-shared Franklin Benjamin Sanborn's sentiment that the methods and data of the social sciences would reinvigorate these older professions by reminding them of their civic duty. This could no doubt do more "service to [the] country than the whole race of politicians put together." ${ }^{17}$ E.L. Godkin, the mugwump editor of The Nation, shared this derision for politicians in his sharp attack on politics as a profession. In attacking a work that defended the spoils-system and its politicians against his proposed civil-service reform, Godkin scoffed at attempts to treat patronage as a natural part of democratic order. He was especially bothered by the notion that politics could be a profession in itself, saying that such a view risked creating a "political priesthood" that could draw America toward an old European concept of "statecraft" that placed politics beyond reform. ${ }^{18}$ Rather than placing the authority of governing in the hands of a "political" class, who would inevitably corrupt the state, using it to meet parochial political ends, reformers like Godkin imagined a state and

\footnotetext{
${ }^{16}$ Daniel C. Gilman, “American Education, 1879-1879," Journal of Social Science 10 (1879): 2-12.

${ }^{17}$ Franklin Benjamin Sanborn, "The Work of Social Science in the United States," Journal of Social Science, 6(1874): 36.

${ }^{18}$ E.L. Godkin, "The Civil Service Reform Controversy," The North American Review 305 (1882): 379394.
} 
society led by professionals who understood the principles or laws of social science. This new foundation of knowledge would better direct governance by assuring that the powers of the democratic state, while still answerable to the general population, were constrained to working within the limits of deeper social laws visible through scientific study. As the historian and ASSA member Charles Francis Adams announced at the Association's first meeting, "the student of social science can devote himself to no better task than to purifying and protecting the system, however crude and unsatisfactory it may appear to him."19 The sense of civic duty that seemed to guide the old professions, it was hoped, would be revitalized in taking up social scientific methods that would teach the state to better govern without meddling with social order or natural law.

The hope of ending political corruption by "purifying and protecting the system" through social scientifically directed reforms had far-reaching consequences. First, as liberal reformers brought the methods of social science to bear on politics and the core apparatuses of the administrative state, they shifted the rationalization of governance toward a belief that the state was best governed through technocratic, social scientific systems which only professionals had the capacity and luxury of time to grasp. But, perhaps more important, in order to uphold a view that governing through social scientific laws was possible, these professionals understood that it was imperative to appear insulated from both the power that had ossified in the

\footnotetext{
${ }^{19}$ Charles Francis Adams, "The Protection of the Ballot," Journal of Social Science 1 (1869): 91, 108-109,
} 
state and from societal influences that sought to direct state power. While a number of accompanying terms were developed to demonstrate this distinction, among the most important accompanying conceptual structures was that of liberal internationalism.

\section{Early International Organizations \& the Rise of Liberal Social Science}

As a chapter in the history of American foreign relations, Frank Ninkovich has noted, "the Gilded Äge remains the golden age of isolationism" In most accounts of American foreign relations and political history. ${ }^{20}$ Even as the US became an economic juggernaut on the world stage, high tariffs meant that at the moment American exports historically peaked in 1867-1885, the state and most of American society remained most preoccupied with consolidating US territory and populations on the continent. This appears isolationist if one assumes that American expansion was a natural manifestly destined spread of the US across the space we now recognize as the Continental US. Using this logic, America can easily be seen as not focused on events across the ocean, but with "domestic" concerns. ${ }^{21}$ Leaving aside the imperialistic assumptions that must go into this reading of American history, even if one were to assume that American's were not being internationally minded in the Gilded Age,

\footnotetext{
${ }^{20}$ Frank Ninkovich, Global Dawn: The Cultural Foundations of American Internationalism (Cambridge: Harvard University Press, 2009), 15.

${ }^{21}$ For realist interpretations of late nineteenth century foreign relations that focus on the conduct of the state, and treating the continental US as the territorial embodiment of the nation's interests and see Norman A. Graebner, Foundations of American Foreign Policy: A Realistic Appraisal from Franklin to McKinley (Wilmington: Scholarly Resources, 1985) especially chapters 2 and 3. For more recent accounts that take on this logic see Walter Russell Mead, "The American Foreign Policy Legacy," Foreign Affairs 81 (2002): 168; Paul R. Krugman, Pop internationalism (Boston: MIT Press, 1997), 207-212.
} 
there was certainly a concept of internationalism already circulating in American and writing and thinking of the time. A quick examination of mid to late-Victorian liberal circles in both the US and the UK reveals a particular awareness, as Ninkovich shows, of the need for a language and practices that could make sense of the increased flow of goods and people across the globe without resorting to the language and structures of empire that informed the internationalism of so many Europeans. Like Stanley Hoffmann notes, the international dimension was never an afterthought for liberals and liberal political thought, but rather was consistently a key element in balancing their aspirations for universal freedom with the search for liberal knowledge that could explain the historical trajectory of the world as part of a shared development. ${ }^{22}$

For example, between the Congress of Vienna in 1815 and the revolutions of 1848 , four identifiably international bodies were formed-the Royal Asiatic Society, the loosely knit World Evangelical Alliance, the Society of St. Vincent de Paul, and the British and Foreign Anti-Slavery Society. All were based in Britain, except the Paris-founded St. Vincent de Paul movement, and by the 1840s even it had become dominated by an English and Welsh membership. ${ }^{23}$ Perhaps more important, all organs were deeply connected to that nation's rising middling class, made up of lawyers, doctors,

\footnotetext{
22 Stanley Hoffman, "The Crisis of Liberal Internationalism," Foreign Policy 98 (1995): 161.

${ }^{23}$ F.S.L. Lyons, Internationalism in Europe, 1815-1914, (Leyden; A.W. Sythoff, 1963). More precise numbers are presented in G.P. Speckaert, "Un Siècle d'Expositions universelles, leur influences sur les congrès internationaux", Bulletin ONG (Brussels: 1951), 270.
} 
industrialists, academics, politicians, and men of letters. Though woefully understudied as such, these early groups of professionals, philanthropists, and humanitarians gravitated toward the social problems created by industrial modernization, and were actually symptoms of as much as remedies for the very globalization of trade that was lifting the middle-class and professionals to a new influence in the management of states and governance. For early international organizations, the humanitarian efforts of coordinating charitable acts, and particularly the abolition of slavery, were less about directing society through states and more about creating the civilizational conditions, regardless of jurisdictional boundaries, where states, sovereign rulers and court customs did not impinge on the liberty of individuals. ${ }^{24}$

From these first international humanitarian organizations, particularly the anti-slavery movement, emerged a series of legal and social scientific networks that proposed the use of education and reform, developed apart from the state, as the legitimate way to ensure norms and standards achieved a civic-cosmopolitan appeal. Perhaps the most influential and powerful of these organizations by the 1850s was the British National Association for the Promotion of Social Science, or Social Science Association (SSA).

The story of the SSA serves as an important juxtaposition for understanding the American case, but the storylines also cross in telling ways.

\footnotetext{
${ }^{24}$ For the rise of international norms in an historical context see Ethan A. Nadelmann, "Global Prohibition Regimes: The Evolution of Norms in International Society," International Organization 44 (1990): 479 526. There are some serious problems in the language of "deviancy" that Nadelmann uses, but his examination is one of the few that studies humanist impulses, within international organizations, as integral to the development of modern instrumental norms and standards. He also makes a convincing case for why these behaviors must be understood as circumscribing the conditions in which states must act.
} 
As historical sociologist Nadav Gadbay has shown, the SSA was a response to shifting governmental practices in Britain that had placed an increasing emphasis on investigatory committees as a core means for promoting and developing legislation that could mitigate the effects of industrial modernization. ${ }^{25}$ But as investigatory governmental commissions fell off because of political tumult in the 1850s, the SSA became an influential "expert forum," where as many as 1200 professionals and civil servants seeking positions in a fast expanding bureaucracy met and "constituted the driving force of social investigation and formulation of social policy."26

The SSA served as more than a place for lofty academic discussion. Historians still argue about why the professionalization and academicization of social science happened later in Britain than it did in the Americas, France, and Germany, but one line of historical study has suggested that the SSA served an important performative function for that nation's emerging liberal, bourgeois class, who felt pinched between a stagnant gentry class and growing working-class movements. ${ }^{27}$ The SSA, then, was an important showcase where crusades for prison, sanitation, and education reform generated public interest and popular support, and further lent support to the mid-Victorian belief that investigatory technologies built on the professional virtues of self-discipline or self-regulation could offer a social authority that

\footnotetext{
${ }^{25}$ Gabay, The Political Origins of Social Science, 186-241.

${ }^{26}$ Ibid.

${ }^{27}$ Lawrence Goldman, "The Social Science Association, 1857-1886: A Context for Mid-Victorian Liberalism," The English Historical Review 398 (1986): 95-134.
} 
bypassed inefficient state-centered commissions while still offering moderate reforms. It is thus hard to understate the significance of the SSA in the governmentalization of social science, in the rise of bourgeois norms as the core of social science, and on the formation of political-ideological alliances in the UK and US around the ideal of bourgeois social authority generally. Lawrence Goldman has argued that the very concept of "expertise" dates to the 1860s and mid-Victorian political discussion around how to ensure experts' influence in the state. ${ }^{28}$

Even though a substantial portion of the SSA was made up of politicians who aimed at labour reform, rising organized labour forces were suspicious of how the association seemed less concerned with informing the opinion of statesmen than with using facts and principled studies "from a professional point of view" to "address the community at large." ${ }^{29}$ And yet, even segments of labour would join the SSA by the mid-1860s, while those labourists who broke from the association for failing to take a sufficiently radical enough stance on industrial issues would still emulate its conference, periodical, and expert-driven structures. Importantly, the SSA was not shy about its politics. It aimed explicitly to influence legislation and government. As Theodore Porter has noted, statistical science societies and many of the core members of the overlapping Manchester society (the core of British laissez faire political

\footnotetext{
${ }^{28}$ Lawrence Goldman, Science, reform, and politics in Victorian Britain: the Social Science Association, 1857-1886 (New York: Cambridge University Press, 2002), 278-79.

${ }^{29}$ N.A. "Introduction," British Journal of Social Science, 1 (1865-1866): 3-4; Goldman, "The Social Science Association," 109.
} 
economy tradition) feared that the SSA's social science was too political, and threatened to undo the de-politicization that Mary Poovey has shown was at the heart of the modern taxonomy of knowledge that British political economists had used to professionalize and still work closely with state statistical apparatuses. ${ }^{30}$

\section{The SSA and the USA: Shared Foundations for Social Scientific Governing}

In a political system where the state was still largely controlled by the landed aristocracy, the SSA's power resided in its capacity to convince others of its public interest and legitimacy as a moderate site for expert directed-reform. By pulling investigative committees away from Parliament and into an association of enlightened members, the SSA moved inquiry into social problems away from the state, placing the association in a position of political externality but social influence. Though a substantial number of the SSA's members were politicians, particularly Benthamites like John Stuart Mill who continually agitated for improved state efficiencies, it soon became clear that drawing social scientific committees into the ever more articulated "civic sphere" of expertise had the bonus effect of legitimating the notion of a learned middle-class of educated experts as uniquely connected to the social world. The middle class reformer, still of the people but educated to identify the problems that ailed society, could influence the state but never be fully wed to either old political interests, defined as aristocratic or working class,

\footnotetext{
${ }^{30}$ Porter and Ross, The Cambridge History of Science, 28-30; Poovey, A History of the Modern Fact, 304.
} 
or inefficient state bureaucracies. ${ }^{31}$ While SSA reformers would continually take existing state structures as a target of reform, their most lasting legacy was in furthering a sense that the proper running of the state was achieved when administered by professionals within a civic sphere, bounded by social laws best articulated by experts who understood the state, but were never indebted to the interests and apparatuses identifiable in it.

For liberals across the industrialized world, the notion that pressure for reform was most effectively exerted by social scientific experts provided a powerful framework from the 1850 s until as late as the 1880 s. For liberals, Europe was a mostly bleak place in the 1850 s and particularly the 1860 s, as their continued hopes for expanding democratic government and the franchise were met with reactionary force that was startlingly successful. By the mid-1860s, Europe was still ruled through the balance of power regime made up of five great powers that, while residing over an unprecedented half century of peace, contained three absolute monarchies (Austria, Prussia, and Russia) "whose main motive for cooperation," in the words of Martti Koskenniemi, "seemed to be their shared wish to curb any proposal for representative government or increased franchise."32

Against this backdrop, the SSA drew not only an impressively influential crowd of bourgeois reform-minded Britons, it also attracted liberal reformers from continental Europe and the US. By 1867 the first chairman of

\footnotetext{
${ }^{31}$ Goldman, Science, reform, and politics in Victorian Britain, 281.

${ }^{32}$ Martti Koskenniemi, The Gentle Civilizer of Nations: The Rise and Fall of International Law 1870-1960 (Cambridge University Press, 2004), 11.
} 
the ASSA noted the existence of "several such bodies in different parts of the world, framed after the model and advocating the principles of ours." 33 The Boston-based American Association was only one such SSA sisterorganization, and not the first. Social science congresses had been held at Melbourne's World Fair in 1851, and international statistical congresses were held infrequently throughout the 1850 s and 1860s. All had attempted to spread the SSA model, always with an eye to creating an international community of reformers. Internationalism was, in the 1860 s, a powerful tool for showing and understanding that local liberal movements, led by moderate reformers, could achieve more sweeping democratic reforms that challenged the aristocratic and religious powers that were so adept at using the state to cement their authority.

It was no coincidence, therefore, that the first continuously meeting social science association was the International Social Science Association, founded as the Association Internationale pour le Progrès des Sciences Sociales (hereafter referred to as AIPSS). ${ }^{34}$ AIPSS was conceived during early annual meetings of the SSA in Dublin in 1861, when Ernest Desmarest, Michel Chevalier, and Louis-Antoine Garnier-Pagès from Paris met with Michel CorrVander Maeren from Brussels. These four distinguished economists and lawyers "were so much struck by the proceedings" of the SSA that they developed the idea of starting an international organization that would use the

\footnotetext{
${ }^{33}$ Cited in Goldman, Science, reform, and politics in Victorian Britain: 323.

${ }^{34}$ Lawrence Goldman, "Exceptionalism and Internationalism: The Origins of American Social Science Reconsidered," Journal of Historical Sociology 11 (1998): 1-36.
} 
"truths of social science" and spread "throughout the other countries in Europe." AIPSS gathered a membership of about 1000 members, mostly from Belgium, Holland, and France, dominated by middle class lawyers, politicians, doctors, and businessmen. Unlike the SSA, AIPSS took no part in the formulation of national or municipal policies; having no leverage on national governments, it saw itself instead as forum for the exchange of shared civil practices and ideas from various nations of the world. It was short-lived, lasting less than a decade and collapsing in 1866, but its short life highlights just how important certain liberal principles were both to the problematics that focused emergent social scientific associations, and to the larger epistemology of the state, where an international system was seen as instrumental to harnessing, rather than just causally growing out of, modernity.

AIPSS's interpersonal networks and core institutional functions developed around a form of liberalism particularly compatible with Continental traditions: constitutionalism, republicanism, anti-clericalism, and, above all, free trade. While the emphasis on the first three principles made AIPSS a more socially radical body than many of its Anglo counterparts, there was a broader working consensus around the centrality of free trade to developing a strong international system. Michel Chevalier, a former Chair of Political Economy at the Collège de France and a member of the Senate during the Second Empire, nurtured relations with the Manchester school via the SSA and would eventually work with the prominent British Political 
Economist Richard Cobden to negotiate the Anglo-French free trade treaty of $1860 . .^{35}$

\section{Liberal International Law, Displacing the State and Finding a Science of the Social}

The affinity between AIPSS and both the SSA and ASSA went beyond a shared devotion to free trade. Recent research has also shown that the radical-liberal lawyers of AIPPS had been impressed by British Utilitarian and Manchester visions of international law. Just as Sanborn would imagine social science modernizing the older professions in the US years later by balancing the rising power of the nation-state with the search for universal knowledge apart from it, a small number of core legal professionals in AIPSS also saw it as imperative to use their association to create a scientific legal journal that could counter the rising nationalist spirit that had been harnessed by aristocratic forces since the Congress of Vienna (1814-1815) and emphasize what one author called "the superior unity of the great human society." For the liberal lawyers of AIPPS, scientifically guided law (and hence governments) could develop standards across national boundaries, informing legislatures and lawyers on how best to form their own legislation. By this thinking, developing common practices would help assure an international peace that respected the right of sovereign rule, but anchoring that sovereignty to the individual and contract law as social scientific law, rather than divine or natural.

${ }^{35}$ Goldman, Science, Reform and Politics in Victorian Britain, 322-325 
Remarkably, the journal they established, L'ésprit d'internationaliste, conceived of social science as a non-statist, non-political, knowledge best positioned to balance the authority of national sovereignty with liberalism's desire for universal standards or laws. It was clear to many AIPSS members that using social science as a complement to international law provided a sense of universalism to what were otherwise the laws of individual nations, doing so by shifting the conduct of government towards principles and laws that effectively naturalized the liberal ideals of free-trade and individual sovereignty regardless of local conditions and development. Just as one could not talk of states determining the rights of people, this modified and liberal internationalism did not assume that states had the capacity to act as autonomous entities guided by raison d'état. ${ }^{36} \mathrm{As}$ one author in L'esprit d'internationaliste noted of the 1864 Geneva Convention that developed standard provisions for the treatment of wounded and sick soldiers, and a Brussels conference in 1869 on principles for humanizing warfare, the force and capacity for inter-state cooperation did not reside with states. Rather, it resided with a sovereign people compelling states to action. ${ }^{37}$

Of course, public opinion was not interpreted as the whim of the untutored masses. Rather, the public opinion that informed the actions of the state came from elite "opinion that is serious and calm," and "based on the application of certain principles of universal justice, with constant elements,

\footnotetext{
${ }^{36}$ Koskenniemi, The Gentle Civilizer of Nations, 13.

${ }^{37}$ Ibid., 15
} 
an opinion that is gradually confirmed and generalized in the judgment of history." L'esprit was, Koskenniemi argues, "born out of a sensibility that looked for social progress, emphasized responsibility and sought a via media between individualism and collectivism, abstract speculation and political action." Moreover, the work of the journal's writers in emphasizing the centrality of the enlightened expert can easily be seen as an attempt to try to carve out an internationalism that, while it desired democracy and reform, saw the nation as a site where social laws were best examined and interpreted by already bourgeois experts. The journal attacked the concept of the sovereign state per se as monarchical absolutism, but offered a concept of the state as a product of social laws that only transnational liberal social scientists were in a position to see. Unlike the SSA, AIPSS "gave energetic voice to just these fundamental political and economic principles of the liberal order so much for granted that they merited no discussion and gave no rise to debate: hence the absence of discussion at the SSA on the 'boundaries of the state' that was almost entirely absent until the 1880s in Britain." 38

The potential for constructing internationalism around social scientific knowledge was not only recognized by members of AIPSS. Utilitarians in Britain had long seen adherence to liberal principles as antithetical to the reigning view of divine or natural law as a proper basis for law between nations-an objection that became more pointed as the anti-slavery movement forced the question of how to enforce abolition across state

\footnotetext{
${ }^{38}$ Goldman, Science, Reform, and Politics in Victorian Britain., 366, 266.
} 
boundaries throughout the commonwealth. ${ }^{39}$ Before 1833 , courts in the US and UK had arrived at essentially the same conclusion, that the law of nations was, in effect, a neutral force subordinate to civic laws. ${ }^{40}$ The fear of creating a state with the capacity and jurisdiction to interfere with free trade made most liberals skeptical of any attempt to generate a higher law that placed reason and interest solely within the state, rather than within its social body. With the rise of abolitionism, however, liberal jurists on both sides of the Atlantic began to re-write the foundations of law between nations using Jeremy Bentham's notion of the international. ${ }^{41}$ By 1860 , the SSA had established an International Law and Trade division, its sixth section, which focused on the fundamental correlate to trade of developing universal weights and measures, and standardizing trade laws, while agitating governments for further liberalization. ${ }^{42}$ By 1866, cooperating with visiting delegates from Europe and the US, SSA members were openly discussing international law as a project of "codification." Discussion moved increasingly toward the potential for a social scientific foundation for international law formalized by an international parliament and courts.

There were, from the outset, tensions in liberal international law over

\footnotetext{
39 M. W. Janis, "Jeremy Bentham and the Fashioning of 'International Law'," The American Journal of International Law 78 (1984): 405-418.

${ }^{40}$ David Brion Davis, The problem of slavery in the age of revolution, 1770-1823 (New York: Oxford University Press, 1999), 505.

${ }^{41}$ Janis, "Jeremy Bentham and the Fashioning of "International Law," 405-418; H. B. Jacobini, "Some Observations Concerning Jeremy Bentham's Concepts of International Law," The American Journal of International Law 42 (1948): 415-417.

${ }^{42}$ Ed. George Hastings, Transactions of the National Association for the Promotion of Social Science (London: John W. Parker and Sons, 1862), 693.
} 
how to balance a people's right to self-government and their own legal common law traditions-enforced and embodied by democratic states-with a political ontology that posited all populations could become liberal. Some in AIPPS proposed that melding social science with law would place an expert professional class in a position where it was possible to steer law and governance without becoming entrenched in either a state-sheltered political elite or beholden to a fickle populace. The construction of the social world by AIPSS social scientists in this period was not only liberal and reformist, it was also constantly reacting to the perceived need for a structure of internationalism that balanced trade and humanitarianism through laws that inscribed the social norms and standards to be enforced by (but exist apart from) states. As Theodore Porter notes, "social science...developed during the middle third of the nineteenth century above all as a liberal, reformist answer to the upheavals of the era. It was less autonomous vis-à-vis government and urban life than it would become in twentieth century universities," but social science in this period is perhaps best understood as "not itself a calling, but a charitable activity or a manner of exercising some other profession or office." 43

Historians are right to note that "the growth of international nongovernmental organizations was greatly facilitated by the development of

\footnotetext{
${ }^{43}$ Porter and Ross, The Cambridge History of Science, 28.
} 
worldwide networks of goods, capital, and labor" in this period. ${ }^{44}$ However, internationalism was not only a reaction to economic globalization or increased interdependence. The optimism of the 1850s and 1860s, particularly around the legislative influence of the SSA, reveals a widespread belief that the state's main functions ought to be security and administration, with its legislation and management directed by social scientists who would ensure international cooperation-unlike aristocrats or royalty-through the gradual assimilation of national laws into a higher law balancing humanitarianism and trade.

International Law and the Authority of "Teutonism" in American Social Science ${ }^{45}$

For American middle-class intellectuals, particularly those in the northeast, Britain was a touchstone for social and political affairs throughout the Gilded Age. American periodicals and reformers closely followed British society and politics, and saw the rivalry between Tory and Liberal forces in that nation as an inkblot on which to read their own national struggles. As Frank Ninkovich has shown, "reporting on British politics took on a clear black and white aspect, with the great leaders William Gladstone and Benjamin Disraeli

\footnotetext{
${ }^{44}$ Akira Iriye, Global Community: The Role of International Organizations in the Making of the Contemporary World, 1st ed. (Berkeley: University of California Press, 2004), 12.

${ }^{45}$ For works that already explore the effect of Teutonism see, James Farr, "The Historical Science(s) of Politics: The Principles, Association, and Fate of an American Discipline," in Modern Political Science. Anglo-American Exchanges Since 1880, ed. Robert Adcock et al. (Princeton, N.J.: Princeton University Press, 2007), 66-96; cf. Reginald Horsman, Race and Manifest Destiny: The Origins of American Racial Anglo-Saxonism (Cambridge: Harvard University Press, 1981), 64-77.
} 
serving as the foci of good and evil." For the majority of members in the ASSA, while Disraeli was vilified, the Liberal Gladstone was lionized as a champion of anti-aristocratic reform who expanded the franchise, advocated civil service reform, and ardently supported free trade-all causes near to the heart of the ASSA's liberal elite. Gladstone was, one American joumal proclaimed, "by far the greatest leader England has ever had." But he was only the political manifestation of a larger British liberalism that fed the laissez-faire social scientists of the ASSA. "John Stuart Mill was our prophet," Godkin would later write, "and [historian George] Grote and Bentham were our daily food." 46

For the ASSA, from its inception in October 1865, the work of Utilitarians such as Mill and Bentham, and Manchester political economists such as Cobden were the staple of the social scientist's diet. Indeed, histories of American social science have argued that three particular lines of thought fed into what would become recognizable as American Social Science: British political economy, with its defense of laissez-faire economics and articulation of classical liberalism; French sociology, and Auguste Comte's positivism, a conservative defense of scientistic thinking as the culmination of civilized society; and German idealists whose consciousness of the chauvinistic nature of the French claim to universal culture and civility, coupled with their own desire for unification, gave them a particularly statist bias and created the

\footnotetext{
${ }^{46}$ Ninkovich, Global Dawn, 85.
} 
foundation of political science. ${ }^{47}$ While Thomas Haskell has noted that there was little "concrete institutional coordination" between the SSA and ASSA, there was a certain likeness and exchange between the British, the burgeoning reform organization based in Boston and, to a lesser extent, Washington and Philadelphia. The ASSA, one member wrote, "traces its origins to the British National Association from which we have taken the idea and general principles of our Constitution." It also significantly reflected the structural organization of the SSA, leading the Association's second president, Samuel Eliot, to point out the connection in "our namesake and to a great extent our pattern." 48 The ASSA, as Goldman notes, was an example of the cultural transference that occurred between the two self-identified AngloSaxon nations, and also of "a yet wider context of 'scientific internationalism' in an age dominated by liberal ideas and liberal political economy."49

But the scientific internationalism that Goldman identifies was not a static system of practices. Instead, it should be seen as a fluctuating epistemic community that took on shifting forms, projecting a concept of internationalism that was reflected their organization's own internal power struggles, and those with the state and other various political systems. In this

\footnotetext{
${ }^{47}$ Ross, Origins, 45.

${ }^{48}$ Franklin Benjamin Sanborn, "Address of the Executive Committee of the American Social Science Association: Constitution, Address and List of Members," 12; and Samuel Eliot, "Presidential Address," 72 ed. Franklin Benjamin Sanborn and American Social Science Association, Journal of social science: containing the Proceedings of the American Association, (1872).

${ }^{49}$ Lawrence Goldman, "Exceptionalism and Internationalism," 22. What Goldman overlooks is that this self-identification is only possible because this racialism was articulated in emerging social scientific disciplines like anthropology and racial sociology. They melded the positivism that had made the natural sciences so professionally successful, with the quest to preserve some semblance of social order after the collapse of the church or aristocratic orders to make create new unities.
} 
way, the ASSA was a reaction that, while it can now be seen as part of the emergent scientific internationalism Goldman identifies, actually identified itself as internationalist precisely because so many of its members believed that it was among those institutions, often identified as carrying forward "Teutonic" cultural traits that made the US and ASSA historically and structurally contiguous to Britain and the SSA respectively. Put another way, the scientific internationalism of the Gilded Age was practically synonymous with the belief that statistical, legalistic, scientific and social scientific societies were an integral part of the historical march of civilization, which Teutonic, and towards the end of the nineteenth-century was increasingly called AngloSaxon, society had most successfully realized. ${ }^{50}$

To see just how synonymous certain civic institutions and problematics were to liberal internationalism we only have to look at the departmental structure shared among the SSA, AIPSS and ASSA, and focus on those departments where an international system (the international, or internationalism) was explicitly discussed or considered part of its purview. While they would diverge somewhat into the 1870s, the core departments shared by the SSA and ASSA in 1865 were Education, Public Health, Free Trade and Finance, Jurisprudence and Economy. ${ }^{51}$ All were built around the knowledge and disciplinary divisions of an existing professional class that included doctors, lawyers, sanitarians, educators, and political economists

\footnotetext{
${ }^{50}$ Farr, "The Historical Science(s) of Politics," 66-96.

${ }^{51}$ Franklin Benjamin Sanborn, "Introductory Note," Journal of Social Science 1 (1869): 1.
} 
and scientists. And all departments in the ASSA were meant to have a shared institutional space where opinion and intelligence could be standardized so that, as Sanborn proposed, "our lawgivers have the opportunity, as in Europe, of calling upon the wisdom and accumulated experience of persons who have made the welfare of their fellow men a special and long pursued study."

Perhaps because of the focus on informing legislation, combined with the still substantial role of jurists in the professional make-up of both Associations, internationalism was treated therein as largely a legal structure, a corollary to the question of regulating national trade but rooted fundamentally to practices of law. "It is not without good reason," one jurist argued to the SSA in 1862, "that Trade has been combined in one with International Law, for the connexion [sic] between the two subjects is so intimate, that whilst Commerce may be regarded as the handmaid of International Law, International Law has been the foster parent of Commerce. ${ }^{153}$ But seeing internationalism as laws, especially if only those provincial laws created by independent nations to facilitate commercial interpenetration, could not alone provide the liberal reformers in the SSA and ASSA with the universal foundations and knowledge that law anchored to social science could. Rather, only social scientific inquiry, one author argued, could unearth "the laws of that universal society of the human race...that all

\footnotetext{
${ }^{52}$ Goldman, "Exceptionalism and Internationalism," 12.

53 Tavers Twiss, "On Trade and International Law," Transactions of the National Association for the Promotion of Social Science 6 (1862): 71.
} 
men are bound to cultivate" culminating in "the institutions of civil society."

David Dudley Field's An International Code (1866) aptly illustrates this wish to root international law in a social science that was borne out of preexisting civic institutions. A prominent Republican and influential lawyer, Field was also a well-known conservative Whig reformer, GOP organizer, and advocate of the Women's Property Act. Field came to the attention of the British SSA for his efforts, between 1847 and 1865, to codify New York state law, which was procedurally and substantively based on English Common Law. His new notoriety alerted Field that the potential of codification went far beyond his state. In the first issue of the Journal of Social Science, he published his case for codification-previously published and presented to the SSAproposing the "Scientific ordering" of the existing body of rules recognized among nations, defining their rights and duties toward each other." "The law is vast," he argued, and holds "the strongest nations in its grasp," so that "no sovereign is so haughty, no subject so poor, as to be beyond its authority," and yet "the law has not been definitively settled as it should be by the concurrence of the civilized world." Field proclaimed that "a community of nations under the mild and beneficent rules of an international code...guaranteed by treaties and enforced by courts, is within the grasp of the present age." ${ }^{55}$ Field's presentation to the ASSA carefully played up how

\footnotetext{
${ }^{54}$ Ibid., 72.

${ }^{55}$ David Dudley Field, An International Code: Address on the Subject Before the Social Science Association at Manchester, 5 October 1866 (New York: W.M. Read, Book and Job Printer, 1867); for ASSA reading see "An International Code," Journal of Social Science 2 (1870):188.
} 
international law merely enhanced the existing institutional connection between civilized nations but particularly between the shared common law traditions of Britain and America, where international law was merely a matter of codifying civil legal structures already expressed on a shared cultural and civic foundation.

This is not to say that his idea of codification went unchallenged. One British lawyer noted of Field's SSA presentation that it contained problematic assumptions that as nations developed shared legal practices, state structures would also converge. "No nation can enforce its own territorial law beyond the limits of its territory", the lawyer contended, "and the laws of a nation can only have effect or obligation within the territory of another nation by virtue of the express or tacit consent of the latter." By Field's thinking, international law was achieved via consent outlined in treaties, but critics pointed out that treaties among nation-states were weak without comity at the socio-cultural level. On the one hand, as some jurists noted, this perspective effectively privileged the common law tradition and dismissed the Napoleonic code of law that still governed France. Because that code assumed "jurisdiction rests in the individual" rather than the "territorial" or "sovereignty," any standardization through comity or reciprocity would risk being reduced entirely to the level of the individual, challenging the very existence of territorialized states as the containers for jurisdictional authority. ${ }^{56}$ If, however, one privileged British common law, as Field did, it was possible to

\footnotetext{
${ }^{56}$ Transactions of National Association for the Promotion of Social Sciences (1862): 73-74.
} 
territorialize nations with common law structures by universalizing their juridical structures, at the same time calling other nations' sovereignty into question.

As with other attempts to develop a social scientific basis for internationalism around liberalized law, questions lingered as to the proper place of the state, and about who could serve as the interlocutor between national populations-situated in sovereign states-and the cosmopolitan liberal population putatively present in the larger community of nations. For Field, the answer to the first question rested in a scientific codification of legal codes, compiled by lawyers and experts from across the nations, working cooperatively to arrive at acceptable cross-national norms. Law, Field imagined, would direct the energies of nation-states toward international laws reflective of the constitutional values of a global population. Of course, he assumed that the customs and norms that were taken as the aim of codification in the international sphere were those that developed in civilized, "Christian nations." 57

Privileging the British common-law tradition satisfied ASSA members such as Godkin, who believed that innovating governance at the national level was "accompanied, through the mere growth of civilization, by a great many reforms in legislation," but that "reforms in legislation were not its final or main object." "Sovereignty is only a means," Godkin concluded; "the end for

\footnotetext{
${ }^{57}$ Field, An International Code, 182.
} 
which political societies exist is right living."58 For his part in a small transnational community of jurists explicitly concerned with how to facilitate peace through legal standardization, Field is remarkable for his procedural approach to treating sovereignty as a means. Working in law, Field took much of liberal American thinking about US sovereignty in this period and attempted to make it the core of an internationalism that he assumed was an inevitable form of social organization beyond the sovereign nation state. And yet, at the same time, the sovereign nation-state remained an indefinite means to ensuring the achievement of such an international legal framework, and remained anchored to social scientific realities. Guided by a rationality that treated liberal institutions and self-government as natural laws observable to the social scientist, Field's legalistic structure for internationalism reflected the optimism that social science could draw nations into a harmonious social exchange guided by social scientific laws, supplementing and spreading the civic structures already present in the US and Britain.

Many ASSA members attempted to maintain the connection between international law and liberal social science throughout the 1870 s, protecting their own place as arbiters of social order nationally and internationally. Perhaps the most noteworthy defender was Francis Lieber (1798-1873). Born in Prussia in 1798, Lieber was a naturalized American who had moved to Boston in 1827, before teaching political economy at South Carolina College and at Columbia College in New York City. Lieber, a prominent public figure

\footnotetext{
${ }^{58}$ Godkin, “Legislation and Social Science," Journal of Social Science 3 (1871): 116-117.
} 
in American cultural and intellectual circles, was best known both for the work he did for the Union Army (creating the Lieber Code, which later formed the basis of the "laws of war" formalized in the Geneva convention), and for establishing what Ross has called one of the "principal social science traditions formed in the milieu of antebellum America": political science. ${ }^{59} \mathrm{~A}$ prodigious institution builder, Lieber was a founding member of the ASSA and a Republican Party supporter.

Lieber's deeply philosophical commitment to republicanism dated back to his time in Napoleonic Prussia. There, steeped in the German Historicist tradition and romantic nationalism, he developed a theory of the state "as the highest form of social life to which man was destined, and government as a natural extension of the family and a positive good." This Hegelian idea aligned with American Whig ideals about gradual historical development through institutions that expressed the people's will. A staunch advocate of free trade as "the distinct course of history," Lieber did not see increased commercial intercourse breaking down the nation-state. Rather, he imagined it leveling international inequity, effectively assuring that peace was upheld by bringing individual liberty in line with national liberty. But national liberty, Lieber argued in turn, was also integral to assuring individual liberty:

It is impossible to imagine liberty in its fullness, if the people as a totality, the country, the nation...or its government, is not independent on [sic] foreign interference...This independence of national self-government farther implies that, the civil government of free choice or free acquiescence being

\footnotetext{
${ }^{59}$ Ross, Origins of American Social Science, 38-39.
} 
established, no influence from without, besides that of freely acknowledged justice, fairness, and morality, must be admitted..$^{60}$

Internationalism was, for Lieber, a system of relations arrived at through cooperation of states for shared just and moral ends that were at the heart of the nation. The state was therefore a tool for ensuring that the fair, liberal values of the nation reached beyond its borders, while protecting it from less just and moral forms. The ultimate goal of international systems, by this thinking, was not a movement towards a supranational system, but rather to cultivate and equalize the multitude of sovereign, self-determined nationstates. The state was a necessity for consolidated, strong nations each with "a numerous and homogenous population...permanently inhabiting and cultivating a coherent territory, with a well defined geographic outline, and a name of its own...speaking their own language, having their own literature and common institutions." And these states were presumed to have a unified network of developed societal and governmental institutions that would create a plurality of nation-states "equal in...sovereignty and legal rights." 61

Like Field, Lieber imagined laws developed by the conscientious and voluntary actions of individuals apart from but directing legislation in states, which then could work to establish international laws reflective of these social scientific laws. Both men treated the English and American liberal emphasis

\footnotetext{
${ }^{60}$ Cited in David Long and Brian C. Schmidt, "Francis Lieber, Imperialism, and Internationalism," Imperialism and Internationalism in the Discipline of International Relations New York: SUNY Press, 2005), 34.

${ }^{61}$ Ibid., 30-35
} 
on private property and local self-govermment under overarching constitutional principles as the true and just basis for all governance. But only Lieber viewed the development of nations through a Whig's historicist lens, seeing the sovereign nation-state as the culmination of socio-political development rather than a passing point. While Field, his AIPPS, and many in the SSA imagined the bonds of sovereignty shifting from the nation to a larger international governmental form, Lieber imagined sovereign nations working to uplift other nations to equal state forms, "drawing the chariot of civilization abreast, as the ancient steeds drew the car to victory." means in Lieber's concept of the international, just as it was for romanticnationalist liberals elsewhere. The sovereign state, as an expression of the nation, was not going anywhere, and could not be overcome without exposing the nation within to foreign intervention in social and political matters from without.

\section{The Paris Commune and the Threat of Labour Internationalism}

Though Lieber died in 1873, his Whig distrust of any majoritarian democracy reminiscent of Jacksonianism, and his faith in the universality of Teutonic civic institutions as the carrier of liberal values, found new purchase with the controversy over the Paris Commune in $1871 .^{63}$ Perhaps more than any other

${ }^{62}$ Cited in Ninkovich, Global Dawn, 108.

${ }^{63}$ Ross, Origins, 63, 123. While most accounts of the rise of American social science argue that noticeable cracks in the ASSA began to develop with the move to professionalization in the $1880 \mathrm{~s}$, the handling of the 
foreign issue, the Franco-Prussian War and the resulting Paris Commune provided a central event around which young and old Gilded Age reformers argued about the proper shape and role of the state and democracy in America, and, by extension, its relationship to formalized international structures. The installation of the Commune in March 1871, following the French surrender to the Prussians that year, surprised even the most assiduous followers of French politics and society. After an uprising of discontented workers, the Commune established a completely separate ruling authority in the French capital, operating under socialist principles. ${ }^{64}$ Though it only lasted two months, from March 18 to May 28, the Commune generated immense fear among the Gilded Ages liberal elite that the contagion of popular labour struggles and the language of class conflict would spread to American workers. ${ }^{65}$

Though it is unlikely that it alone created such an effect, the timing of the Commune and discussions around it reveal that American rationalizations of internationalism were shifting. Before the Commune, the conceptualization and practices of internationalism in America had been anchored most often to an optimistic faith that liberal social scientific reformers were ideally situated

international question shown here reveal noticeable splits between Whig nationalists and internationalists as early as $1872-3$.

${ }^{64}$ Stewart Edwards, The Paris Commune 1871 (London: Eyre and Spottiswoode, 1971). For more recent accounts of the Commune see Donny Gluckstein, The Paris Commune: A Revolution in Democracy (Chicago: Haymarket Books, 2011); Alistair Horne, The Terrible Year: The Paris Commune, 1871 (Phoenix: Orion Publishing, 2004); David A. Shafer, The Paris Commune: French Politics, Culture, and Society at the Crossroads of the Revolutionary Tradition and Revolutionary Socialism (New York: Palgrave MacMillan, 2005).

${ }^{65}$ See especially Philip Mark Katz, From Appomattox to Montmartre: Americans and the Paris Commune (Harvard University Press, 1998), 179-180. 
to direct the reform of societal problems (such as sanitation, prisons, education, administration etc.) through legislative or judicial mechanisms that did not call for the state to unduly interfering in the natural law or order of things-namely, without impinging on the rights of the individual. These early internationalists were, therefore, mostly accepting of the idea that it was possible to standardize or codify various laws among civilized nations where sovereignty was an indispensable means to a larger cosmopolitan end. But the Franco-Prussian War demonstrated the lingering power of European imperial-states, and the subsequent Commune was interpreted as revealing the peril and possibility of mass social revolution. Both threats, reformers in America would argue, clearly showed that European politics and problems were a menace to the exceptional civic institutions that made the US a stateless state. With little sense of irony, it was actually the protection of this exceptional statelessness that pushed American liberal thinking into a more territorialized vision of the US state, separated and buttressed from the influence and power of Europe.

Lieber's faith that the march of world history culminated in the liberty realized by the American nation, and his distrust in any democracy that overthrew existing social orders, ${ }^{66}$ meant he was supportive of German national unification with the Franco-Prussian war, and vehemently disdainful of the Paris Commune. When he discovered that the Commune had employed banners with his personal motto "No Right without its Duties, No Duty without

\footnotetext{
${ }^{66}$ Francis Lieber, On civil liberty and self-government (New York: Richard Bentley, 1853), 243-55.
} 
its Rights," and that the Société Internationale in Geneva (where leading anarchists and communists met within the Workingmen's International meeting) had also used it in their meetings, he wrote of the "disgust which he felt at the profanation of his favorite term." "Lieber loved liberty and reform," one contemporary eulogy observed of his reaction to the news, "but as rights enjoining moral and juridic [sic] responsibilities." 67 Importantly, Lieber's own idea of how to organize international law reflected his notion of the "Rights of Nations" and the necessity of developing them as equal powers. Lieber imagined a committee composed of "the most prominent jurists of the law of nations, of our Cis-Caucasian race," who would be "not diplomatic, although international," and who would settle questions independently of the state. Their work would "stand as an authority by its excellence, truthfulness, justice, and superiority in every respect." ${ }^{68}$ America was an exceptional nation not only because of its firm adherence to the laws of liberal political economy, Lieber believed, but it was exceptional also because these principles were embedded in the laws and institutions of the nation-state. America had achieved its sovereign destiny by historically realizing its place at the vanguard of liberalism, which it could spread into the world through cooperation with the elite group of European, civilized nations.

Lieber's concept of the international as a legal structure that depended on a liberal, civilized elite directing the energies of the state, as well as his

\footnotetext{
${ }^{67}$ Eliakim Littell and Robert S. Littell, The Living Age (Littell, Son and Co., 1873), 117.

${ }^{68}$ Elihu Root and George B. Davis, "Francis Lieber," Proceedings of the American Society of International Law at Its Annual Meeting, 1907-1917, 7 (1913): 18.
} 
use of the Commune to illustrate America's exceptional liberal-republican democracy as antithetical to unruly mass democracy, echoed sentiments among America's North Eastern elite. Philip Mark Katz has argued that the Commune was the most reported on foreign event in 1870s America, though it served different purposes for different classes and constituencies. Some press sympathetically covered the conflict as a democratic revolt akin to the Civil War, but this "Americanisation" of the Paris Commune was a double-edged sword. ${ }^{69}$ It may have fed a form of American exceptionalism about the US and liberty, but, at least until the country staggered into a depression in 1873 , it also largely cleansed any reading of class conflict from American understandings of the event.

This changed, however, with the first Great Depression in 1873 and the rising specter of a "ragged American proletariat" fomenting radical labor unrest. ${ }^{70}$ During this period, Katz argues, Americans began to speak about the Commune using the language of class conflict in order to reflect back a framework for understanding American socio-political dynamics. This move divided Americans into those who treated the plight of European and American labourers as shared, and those who clung to an exceptionalist belief that American republican traditions, growing suffrage, and plentiful land in the West made them a society that could prevent the social decay that spurred revolutions like the Commune-so long as foreign radicalism was locked out.

\footnotetext{
${ }^{69}$ Katz, From Appomattox to Montmartre, 123.

${ }^{70}$ Ibid., 154, 167.
} 
This exceptionalism, Katz notes, became most pronounced with the massive railroad strikes of 1877 . The Commune received more coverage in the last weeks of 1877 than any other period since 1871, as the now historic Paris uprising provided American commentators with the shibboleth of the "American Commune," a dystopic and polemical concept that was used to delegitimize local and national labour organizations and political machines. ${ }^{71}$

ASSA commentary on the Commune and "The International" associated with it, in the Journal of Social Science and closely connected popular periodicals on internationalism, follows this shift in public opinion, but was still generally staunchly exceptionalist and anti-Commune. In the Northeastern US, labour had grown into a formidable organizational force in the late 1860 s and into the early 1870 s, flexing its political might in state and national elections. In Massachusetts, the first Labor Reform party sprung to life around the cause of work hours and conditions in that state, forcing Republicans to court the support of labour more overtly. The ASSA had already placed itself in the middle of such upheaval, heeding calls for a commission on the reform of working conditions and hours of work in Massachusetts. Members came out looking more like defenders of the status quo than reformers for their fear of giving the state the capacity to regulate hours. ${ }^{72}$ But by 1871 Senator George F. Hoar (R-Mass), with the support of several representatives from his state and New York, pushed a bill to establish

\footnotetext{
${ }^{71}$ Ibid., 172.

${ }^{72}$ Cohen, Reconstruction of Liberalism, 35.
} 
a federal commission on wages and labor hours and the division of profits between labour and capital. In the debate that ensued, several Republicans praised the Communards and their valor against reactionary forces, arguing to Congress that it "had not heard their side of the story," and that theirs was a cause "entitled to the respect of Americans everywhere." ${ }^{73}$ A small number of newspapers, and even a few prominent American political figures such as Wendell Phillips, defended the Commune, arguing that its battle was a republican fight, much like the American Revolution and efforts to overthrow slavery. ${ }^{74}$

But ASSA members such as Godkin and George Curtis were deeply suspicious of the Commune and the concurrent rise of the International Workers Association, treating each as malignant outgrowths of a corrupted social order. Godkin's Nation was transfixed by the Commune, which became its single most-reported event from abroad in $1871 .{ }^{75}$ Indeed, Nancy Cohen has argued that the Commune was a definitive moment for Godkin, who publicly began to question America's insularity from the labour unrest that had created divisive class politics in Europe. In an atmosphere where commentators vastly over-estimated the strength of the North American

\footnotetext{
${ }^{73}$ David Montgomery, Beyond Equality: Labor and the Radical Republicans, 1862-1872 (Urbana: University of Illinois Press, 1981), 370-372.

${ }^{74}$ Samuel Bernstein, "The Impact of the Paris Commune in the United States," The Massachusetts Review 12 (1971): 438. The North American Federation of the International had about 5000 members at its height, early in 1872, but French police observers in the US put the number at as much as 1,400,000 in April 1876, just as the organization's end was nearing.

75 "Index to volume XII, January to June 1871," Nation. Half the column inches devoted to stories outside the United States during the first half of that year focused on France, tripling the number of stories from any other foreign state--including Britain.
} 
Federation of the International, Godkin concluded that the rise of the Commune-despite its defeat-foreshadowed American events where political corruption and party machines had been unreformed. ${ }^{76}$ The ideas of the Commune and the International, Godkin warned, "will not cease to spread ... until they have made one great attempt for the conquest of modern society, and have in that attempt shaken our present civilization to its foundation."77 Perhaps more than any other ASSA member, Godkin took the Commune as an indication of serious and global social problems. ${ }^{78}$

He sympathized with earlier strikes and saw unionization of labour as an important development in the US, but believed that unions and organizing were for labour what sovereignty was for the nation: a temporary solidarity on the way to a more just and scientific society. ${ }^{79}$ The idea of making workingmen's organizations the permanent basis for a state and government offended Godkin-the-anti-political more than Godkin-the-anti-majoritarian. Certainly, the Commune government had "shown itself capable of maintaining an army, and carrying on war for two months," but for Godkin this was not proof of competence to govern without established state systems so much as proof "that it is not impossible for a great crowd of persons, whom society denounces as lunatics and loafers to seize on the government of a

\footnotetext{
${ }^{76}$ Bernstein, "The Impact of the Paris Commune in the United States," 438-41.

${ }^{77}$ E.L. Godkin, "The Week," Nation, June 1, 1871.

${ }^{78}$ Bernstein, "The Impact of the Paris Commune in the United States," 440-441.

${ }^{79}$ Cohen, Reconstruction of American Liberalism, 50-51.
} 
great capital, and administer it for a time, at all events." ${ }^{80}$ Godkin saw real social questions in the Commune and was more delicate than most not to fall back on "red-scares" rhetoric or treat it as little more than a horror story. ${ }^{81}$ But the Commune nevertheless showed Godkin that the rise of a new "international" risked his American state form, structured as it was around the fallible idea of self-discipline and social authority built on institutions and values he posed as the true and natural basis of governmental authority.

George William Curtis, then-editor of the North American Review and ASSA President from 1873 to 1874 , was typical in his view of internationalism as the balancing of interdependence through trade with humanitarian reforms to ameliorate its most negative consequences. Curtis joined Godkin, warning of the threat of social disorder and savagery and comparing Parisian workers to barbarians and "Comanche hordes." 82 But Curtis's North American Review was less sympathetic with domestic labour than was The Nation, accusing local organizers of falling victim to "foreign influence." The Commune was part of a rising "International," one Review author argued, the rise of worker organizations in Paris symptomatic of historical conditions particular to France, where the Jacobin overthrow of the "Guardians of order" during the

\footnotetext{
${ }^{80}$ E.L. Godkin, “The Commune' and the Labor Question," Nation, 18 May 1871, 334.

${ }^{81}$ Bernstein, "The Impact of the Paris Commune in the United States," 439-440; For a more conservative reading of Godkin see Edward T. Gargan, "The American Conservative Response," International Review of Social History 17 (1972): 240-249; For broader context on the Commune as conflated with The International see Michael Forman, Nationalism and the international labor movement: the idea of the nation in socialist and anarchist theory (University Park, Penn.: Pennsylvania State Press, 1998), 58-65. Importantly, some including the likes of Woolsey were careful to differentiate between the actions of the Commune and those of The International in their political scientific work.

${ }^{82}$ Katz, From Appomattox to Montmartre, 131.
} 
French Revolution had created cycles of violent social revolution. ${ }^{83}$

The Commune's "socialistic agitation," one ASSA presenter echoed in 1873, "has given Europe two Napoleons. It was Jacobinism running to Communism which compelled France...to choose between endless anarchy... and a concentration of power in the ablest hands; and of that came the First Empire," just as later anarchy brought about the Second Empire. The International was not the product of some legitimate class-consciousness; it was the result of weak social leadership fomented by state corruption and its failure at social reform. If, as Curtis argued to the ASSA in his Presidential speech that year, "all advance from barbarism to civilization is the development of social science," then barbarian Communards and the new Internationalists seizure of a civilized nation like Paris was not due to a legitimate right to govern, but because that nation lacked social authority in modern institutions and laws built on social science. ${ }^{84}$

The crisis of the Commune and mid- and late-1870s labour strife in the US pushed American internationalists deeper into the chauvinism of patriotic nationalism and more obviously in line with American exceptionalism, privileging the social authority of a small group of liberal reformers. As labour organizing grew, political parties splintered, and strikes spread across the US, the hope of an international system built on social comity between all civilized nations, consummated through international trade and

\footnotetext{
${ }^{83}$ A. S. Hill, "Causes of the Commune," The North American Review 116 (1873): 90-109.

${ }^{84}$ George William Curtis, “Opening Address,” Journal of Social Science 6 (1874); 33-37.
} 
circumscribed by international law, seemed more and more dubious. Cracks appeared, however, as the optimistic cosmopolitanism that had defined American liberal internationalism before 1871 began to show up in the ASSA. As early as that year, Joseph Wharton, a prominent philanthropist, industrialist and co-founder of Swarthmore College and the Wharton Business School at University of Pennsylvania, complained to the Association that imagining a world where nations would matter gradually less as trade increased interpenetration ignored the staying power and importance of nationalism as an important basis for statehood. "The advocates of unrestricted commerce in particular seem to me," he argued, "to disregard too much the existence of nations, each of whom is to take thought of his present and particular welfare alone, unmindful of his nation, for the collective wellbeing [sic] of which no one is to care." 85

It was not enough to follow the Manchester school of political economists, Wharton noted, and assume that the "entire race of man is but a band of brothers...Accidentally gathered into groups designated by the geographical expressions of America, England, France of the like." Nations will always develop, he implied, and it was natural for local labour to wish to benefit from its "own markets," and therefore simply removing trade tariffs in nations overlooked John Stuart Mill's observation that "a protective duty, continued for a reasonable time, will sometimes be the least inconvenient mode in which a country can tax itself for the support of an [industrial or

\footnotetext{
${ }^{85}$ Joseph Wharton, "International Industrial Competition," Journal of Social Science 4 (1871), 49.
} 
manufacturing] experiment. ${ }^{86}$ Wharton, like Mill, believed an expert-manned Commission of Customs could properly guide "conditions of trade" cultivating cooperation between nations but still respecting the unique relations between labor and capital within them, and simultaneously assuring American sovereignty and its national exceptionalism.

Wharton was not in a majority among ASSA reformers in arguing for advocacy on behalf of labour by the state even before the events of 1871 . While for him the Franco-Prussian War illustrated the power of nationalism, for others the Commune illustrated the startling power of mass social upheaval, making the idea of a socialized state more repulsive and emphatically "foreign." Still, some political economists such as Francis Walker echoed Wharton in noting that classical economists had left out the historical effects of "economic and social structure, of national differences, and of actual conditions." Walker was more sympathetic to industrial protest in the US and Britain than many ASSA colleagues, arguing in The Wages Question (1876) that, contrary to economists who thought wages came from a fixed pool of capital at a given moment, wages were a return on projected increases in production. ${ }^{87}$

Although he modified the precepts at the base of a capitalist economy, Walker reinforced a functionalist interpretation of American social order in the US, one that posited that workers and capitalists alike had a responsibility

\footnotetext{
${ }^{86}$ Ibid., 66.

${ }^{87}$ Ross, Origins, 83.
} 
to uphold economic cooperation within the existing natural/social order of things. Walker's response to the social upheaval of the labor revolts across the West was to retreat as Lieber did to an American exceptionalism where civic liberal-republican institutions ultimately directed the state, and limited its interventionist power, by influencing social norms and standards at the social level. Such institutions, which "had thus far kept the working class sound-general education, free access to trade and land ownership, and full civil and political rights"-were still effective tools in the American art of governing. ${ }^{88}$

While some ASSA reformers showed moderate flexibility throughout the 1870s around the modification of economic levers, such as wages, because they insulated America from foreign class-antagonism, the Commune seemed to prove that the exceptional continuity of social order that the US enjoyed was a product of particularly institutions that were taken as embodying Teutonic cultural characteristics creating certain civic institution that acted as vessels that carried liberty from Germany, through England, and stopping to rest in the US. ${ }^{89}$ Again, Godkin is instructive as a case study of this point. Like most members of the ASSA, before the Commune Godkin had openly identified with Mill's Principles of Political Economy. ${ }^{90}$ He agreed that "immorality which pervades the commercial world, and taints nearly every

\footnotetext{
${ }^{88}$ Ibid., 84.

${ }^{89}$ John Higham, "Herbert Baxter Adams and the Study of Local History," The American Historical Review 89 (1984), 1228

${ }^{90}$ William M. Armstrong, E. L. Godkin: A Biography (New York: SUNY Press, 1978), 43-4.
} 
branch of business" was not a sign of the failure of the laws of political economy, but rather a result of

the decline of habit and social force, before mental and moral culture has reached a sufficiently advanced stage to take its place. The breaking up of old habits that the [French] Revolution mainly consisted. The habit of obedience to the law in which people are bred...no amount of physical force on the side of the law would suffice to preserve order and save civilization. If a people once loses it, and has not sufficient moral culture to take its place, the result, as we see in Mexico, is anarchy, until long suffering has roused the social instinct into activity. ${ }^{91}$

By the late 1860s, Godkin and many in the ASSA had already begun publicly to split with the likes of Mill over the idea that the state could offer temporary relief to the working classes. ${ }^{92}$ Godkin believed in "Economic Man", whose actions could be predicted "with almost as much certainty as the operation of a law of chemistry or physics," and this made him much less compromising than Mill..$^{93}$ Unlike those historicists, particularly German-influenced thinkers, who tried to "supply morality to trade through some sort of government interference, not as yet clearly defined," Godkin imagined a world governed through the social order cemented by Anglo-Saxon habits and institutions. ${ }^{94}$ He understood by the 1870s that followers of German historicists, French

\footnotetext{
${ }^{91}$ E. L. Godkin, "Commercial Immorality and Political Corruption," The North American Review 220 (1868): 250-51.

${ }^{92}$ Edward Caudill, "E. L. Godkin and the Science of Society," Journalism Quarterly, 66 (1989): 57-64; Armstrong, E. L. Godkin, 72-3.

${ }^{93}$ E. L. Godkin, "The Economic Man," in Godkin, Problems of Modern Democracy: Political and Economic Essays, ed. Morton Keller, (Cambridge: Harvard University Press, 1966), 159, 162. See also E. L. Godkin, "The Difficulties of Economic Discussion," The Nation, 22 July 1869, 65; and see "The Working-Men's View of Capital," The Nation, 4 February 1869, 85-6 for an earlier, less absolute characterization of the scientific nature of economic laws.

${ }^{94}$ Godkin, "The Economic Man," 158, 159.
} 
Positivism, and British liberal-Utilitarians, with Mill as their torch-bearer, offered increasingly sophisticated rationalizations for incorporating labour demands and state regulation into their national and international worldviews. And he recognized that such intellectual underpinnings had the power to legitimize alternative political forces by giving voice to the new social laws at their base. "No 'cause' has as much chance of success in our time," Godkin wrote, "which has not a regular 'philosopher' at its back." But, "Mr. Mill," he noted, "supplies the bold intellectual port of which so many rather weak and noisy bodies make so comical a display... [about] the labor movement."

But the state and philosophers could not maintain order alone. The social upheavals around the Commune revealed to Godkin the undesirable effect of what he saw as state intervention in social order. The split between him and Mill was indicative of a larger rift that developed between the ASSA and SSA as the former became increasingly hostile to labour through the 1860 s and 1870s, and the latter actively circumscribed organized labour into the social and political system. ${ }^{96}$ But the exceptionalist view that America's Teutonic civic-institutions relieved it of the need for a strong state, and allowed it to stand outside the forces of history and social forces racking Europe, had ironic ramifications.

At the time when many ASSA members broke with their British counterparts over the labour question, the retreat to chauvinistic nationalism

\footnotetext{
${ }^{95}$ E. L. Godkin, “The Commune' and the Labor Question," The Nation, 18 May, 1871, 334.

${ }^{96}$ Goldman, "Exceptionalism and Internationalism,"18-19.
} 
and exceptionalism also created a substantial break between American legal internationalists in the ASSA and continental international social science groups like AIPPS. Following the ideological and institutional rifts developing in the American social science scene, the years that followed the Commune revealed a another significant shift in American thinking about internationalism, which provided a key field of contestation for American social scientists to explicate their interpretations of the state-society divide in the US. There were those who advocated codification and international integration versus those who championed Lieber's vision of national sovereignty as the highest form of development. For the first camp, liberalism was treated as the historical force that diffused governance to the level of the individual, such that the state's territorial sovereignty was simply a reflection of nationalism, but only a finite means to a larger historical progression away from the state.

For those who would come to champion Lieber's notion, sovereignty was still a means, but the nation was the culmination of that progression, and the American nation had already demonstrated the protection of liberty's dependence upon existing sovereign territorial alignments. Godkin was in this second camp, arguing for international laws but skeptical of attempts at codification. In 1875 he wrote that the "philosophers and professors" meeting at The Hague were better off "reforming people":

[i]t would be at once recognized as somewhat an absurdity for a body of distinguished clergymen, leading fathers of families, and editors to get together and hold a convention for the study of reform of morals 
over the world. Yet there is really much greater reason why this should be done than that a number of jurists and philanthropists should undertake to amend and codify the law of nations. ${ }^{97}$

Referring to the large 1878 Peace conference in Paris, Godkin maintained that no "mechanical contrivances" such as "courts of arbitration and the draughting [sic] of rules for a government of disputants when they get angry" the comity that came through social harmony. Courts and rules were best seen as sustainable ends, coalescing around shared social and moral laws. International law had to follow from these deeper social laws, knowable through social science and already present in the end state for the US and Britain. A remarkable shift, then, began in the period after the Commune. Some reformers affiliated with the ASSA increasingly fell away from liberal exceptionalism and moved towards an American exceptionalism that treated the US state form as integral to the preservation of liberty on a global scale. This was nowhere more evident than in the changing ontology of internationalism at the base of legalist international organizations. In 1873 came the establishment of the International Code Committee in the US, the Institut de Droit International, and the Association for the reform and Codification of International Law. Not coincidentally, Field was the central-if not the only-American at these organizations' founding meetings. ${ }^{99}$

\footnotetext{
${ }^{97}$ Armstrong, E. L. Godkin, 185-187.

98 Ibid.

${ }^{99}$ Irwin Abrams, "The Emergence of the International Law Societies," The Review of Politics 19 (1957): $361-380$.
} 
Though legalists such as Field had worked closely with the peace movement before 1873 , by the time of the Brussels peace conference that year, even Field had shifted towards advocating a programme for arbitration that raised the advocated military sanctions, and (echoing the sentiments of Johann Kaspar Bluntschli, professor of political science at Hieldelberg University and a long-time correspondent and admirer of Lieber) proposing that issues of conflict between nations arising from "the vital interests" of states ought to be excluded from any international arbitration. Placing disarmament and other "internal" state matters beyond the purview of international law was tantamount to a betrayal of the cosmopolitan humanitarianism for many in the peace movement. By 1880, Field was working closely with Bluntschli and Theodore Dwight Woolsey (Lieber's former student and then Yale College President) to establish a code of conflict law and to promote American branches of the International Arbitration and Peace Society of Great Britain and Ireland (est. 1880) as distinctly legalist and professionalist societies. As one author has noted of these same developments, the splintering of legal societies from the peace movement was partly an attempt to publicize the splinter groups as distinct professional bodies by "using the propaganda devices which had hitherto been left to the peace movement." But it was also retaliation against the growing alliance, in Britain at least, between the Peace Society and the International Workingmen's Peace Association, for their stance against British imperial annexations and their demand for parliamentary control over foreign 
policy. ${ }^{100}$ American jurists working with international legal organizations followed a similar pattern, distancing themselves from the peace movement, retreating to increasingly professionalized spaces that methodologically and institutionally projected a central role for themselves and legalism in governing the international.

It was hoped that lawyers articulating social scientific laws could balance the end goal of a liberal international order with the demand for recognition of distinct national identities. International organs that connected professionals across the West believed that their work and institutions were essential to stateless, civil society, as only they could transmit order and gradual reform of the social, rather than radical change of the political, the latter being what pacifist, socialist or labour internationalism ostensibly would do. "Sovereigns and States are under no obligation to heed their suggestions," then University of Michigan President James B. Angell argued of international legal organs like the International Arbitration Society. "But I believe that the clear and distinct utterances of these learned bodies on grave questions cannot be without marked a influence on public opinion, and so on the policy of nations." It was not that legal-minded internationalists were abandoning the vision of cosmopolitan peace altogether, Angell told the American Social Science Association at one meeting, assuring them that "the visions of good men like St. Pierre, Liebnitz, Rayual, Bentham, Kant...of

\footnotetext{
${ }^{100}$ Francis Harry Hinsley, Power and the Pursuit of Peace: Theory and Practice in the History of Relations Between States (Cambridge University Press, 1967), 128.
} 
securing perpetual peace, may still remain visions." Nevertheless,

The extravagant expectations of some advocates of arbitration and codification may not be realized [and] wars as absurd as the Franco-German war may still be waged...[but] the civilized world has reached a point, thank God, it prefers peace to war, where neutral rights will be guarded as jealously as belligerent rights, and where its publicists are sure to be sustained by the moral sense of the world in trying to shape international law so as to conduce to what are believed to be the true interests of humanity. ${ }^{101}$

Law itself was not only at the core of this liberal international order; for Angell, the work of non-state civic organs like international legal associations held up a liberal order that governed beyond but within states, and also at their borders to buttress sovereignty.

But speaking as the "judicial conscience of the civilized world" depended on an organization's ability to embody and demonstrate the divide between professionals who accepted the centrality of the sovereign nationstate to international order (and therefore arbitration) and advocates who believed in working more immediately towards cosmopolitan peace (via codification). ${ }^{102}$ In the US, the split of international arbitration organizations from their one-time allies helped stem a growing skepticism about those internationalists who had till then cooperated with labourists, socialists or other groups seen as "illiberal". Early in 1871, the settlement of the Alabama Claims, under the Washington Treaty of 1871 , breathed some legitimacy into the idea of arbitration. After arriving at a settlement that saw British

\footnotetext{
${ }^{101}$ James B. Angell, “The Progress of International Law," Journal of Social Science 8 (1876): 40-54.

${ }^{102}$ Koskenniemi, The Gentle Civilizer of Nations, 14-17.
} 
reparations paid to the US for the sale of arms to the Confederacy during the Civil War, Lieber predicted that "the opinion of our race, perhaps, would soon ripen to an energetic conviction that arbitrators ought to be permanently appointed, ready to meet and act when called upon." But more importantly, Lieber and many of his colleagues saw the settlement as proof that "the Germans, the English, and the Americans" should "take the lead" and assure "the steady tramp of onward civilization." 103

\section{New Professions and Methods in Civic Internationalism}

The shift of social scientific authority away from generalists, publicists, advocates and philanthropists cannot be understood as exclusively ideological or as a reaction to external changes in the world. Rather, the interplay between concepts of internationalism and the American nation-state helped usher in new professional identities, and vice versa, by offering a conceptual foundation around which methods and institutional standards were streamlined to sit at the center of American political science. From the mid1870 s to the 1880 s, some experts in international law clung to old institutional networks like the ASSA, where they remained connected to the scientism of liberal political economy. However, as Ross argues, with the new "gentry" self-consciousness that developed in the 1870s around claims of AngloSaxonism, the nationally-minded reformers of organizations like the ASSA

\footnotetext{
${ }^{103}$ Francis Lieber, "On Some Points in International Law," The Miscellaneous Writings of Francis Lieber: Contributions to Political Science, Including Lectures on the Constitution of the United States, and Other Papers (New York: J.B. Lippincott, 1881), 322.
} 
followed the example of "natural scientists who had been pushing American scientific institutions toward greater professional rigor" by focusing on academic reform. ${ }^{104}$

As a civic institution, the university held particular power and cachet among those whose American exceptionalism revolved around civic institutions, professionalism, and law. Angell even attempted to explain the "power" of new international legal associations as "akin to that of certain universities in the middle ages; e.g. that of Paris in theological matters, and that of Bologna in law."105 The university was a powerful metaphor for projecting a state-society divide, as an institution that "articulated liberty" and protected the American social order from foreign influence. The university was, for an emerging cadre of jurists and social scientific reformers, apart from the state and other extrinsic activist forces, but still able to channel popular opinion by articulating otherwise inarticulate desires for selfgovernment into institutional forms. ${ }^{106}$

While some of this new gentry class (especially jurists, publicists, and those "social reformers" who were locked out of the move to academia) clung to the ASSA, a new guard of university reformers carved out a distinct professional space for international law in university history and political science departments. Overwhelmingly composed of Lieber's students and close colleagues, this new guard of university experts imagined an American

\footnotetext{
${ }^{104}$ Dorothy Ross, The Origins of American Social Science, 61-62.

105 James B. Angell, "The Progress of International Law."

${ }^{106}$ Lieber, On Civil Liberty And Self-Government, 276.
} 
state and international system fortified by civic institutions. They were convinced by Lieber's argument that "to last long-to last with liberty and wealth-is the great problem to be solved by a modern state," and that only the "institutional self-government" developed by the Teutonic peoples and sheltered in its institutions could do it. ${ }^{107}$

One of Lieber's admirers was Daniel Coit Gilman, the first President of Johns Hopkins University (where graduate studies were introduced to North America) and a founding member of the ASSA. Upon arriving at Johns Hopkins (after starting his career as a librarian and institution-builder at Yale) he set to work gathering and archiving Lieber's personal and published papers. He went on to do more than any other academic (save perhaps Theodore Woolsey) to document, publicize, and re-publish Lieber's library as part of a larger liberal international circle of jurists-gone-political scientists. Housed alongside the works of Lieber's German colleague, Bluntschli, whose library was gifted to the university in 1882 by German immigrants, and Lieber's correspondence with the French republican and former supporter of the Paris Commune, Édouard René de Laboulaye, Gilman treated these collective works as proto-political scientific and historical documents of the liberal and

\footnotetext{
${ }^{107}$ Ross, Origins, 41 . Lieber's connection to the generation of liberal internationalists and university reformers is more than coincidental. As Ross notes, "Lieber's version of historico-politics would be so attractive to the reforming university gentry" because it offered a comprehensive national and international framework in which to situate American exceptionalism in the spreading crisis of the $70 \mathrm{~s}$ and into the $80 \mathrm{~s}$. By framing American national sovereignty as the archetype of civil liberty and, by extension, positing an international system built around liberalization by civic/social rather than state means, Lieber's liberal internationalism coupled the nationalist-legal emphasis on maintaining juridical sovereignty with the philosophical ideal of a cosmopolitan peace. The spread of liberalism, by this thinking, only occurred through a gradual adoption of the institutions that historically developed in Teutonic civic-cultures, and could not be forced by an activist state.
} 
meritocratic movement that had created a truly international law. ${ }^{108}$

Like Gilman, Theodore Dwight Woolsey played an initiating role in the transition from the generalist environment of the ASSA to the distinct university-anchored professions of political science and history. A student of Lieber's and President of Yale from 1846-1871, Woolsey wrote of the need for a distinct discipline of Political Science, and even though he retired in 1872, attacked the rise of The International and the Commune as symptomatic failures of socialism and communism's attempts to institute state activism. Political science, he argued, understood the state as the "large association, stretching over a vast territory, acting by itself and empowering others to act, leaving individuals in their pressdom, but providing for numerous wants of a whole community." But the state was not society; rather it touched it at a "multitude of points, while jural institutions touch them at very vital, indeed, but at single points." Thus, Woolsey was dismissive of the idea that a jural state "under private control" could be achieved through international law. "It would manifestly be a failure," he insisted, because it marked an attempt to force a polity where there was no common ethos. Internationalism for Woolsey, as for Lieber, was only a legal system that protected the right of sovereignty while maintaining the view that "a universal society and the spread of all truth and improvements" becomes possible when nations are brought together by a common sense of want, and "what is due between

\footnotetext{
${ }^{108}$ Daniel Coit Gilman, Bluntschli, Lieber and Laboulaye (Baltimore: Privately printed for a few friends in Baltimore, 1884).
} 
nations." 109 But the protection of liberty, when read through this view of the state and accompanying historical laws, was fixed to the development of Anglo Saxon institutions and to democratic and liberal sensibilities.

Andrew Dickson White, a student of Woolsey and colleague of Gilman, would also help institutionalize political science and its cognate of international law in the university. After sitting as Chair in History at the University of Michigan in 1857, White sat in Congress for a term and returned to the academic fold after cooperating with former Senate colleague Ezra Cornell to establish Cornell University in 1865. White served as Cornell's first President in 1867, where he promptly built, on paper at least, "a school of political science." 110 White shared Woolsey's view of the social development of the state, and when he served at the behest of President Grant in 1871 on a commission to study the possibility of annexing Santo Domingo, the racialist implications of this reading of history found a political voice in Senator Carl Schurz, whose speeches White felt, "appealed both to reason and to patriotism," and his arguments on "the danger of extending the domain of American institutions and the privileges of American citizenship over regions like the West Indies carried great weight with me." Though White would eventually file a report that advocated annexation, he respected Schurz for challenging Republican Senators to name a single "republican institution, based upon popular self-government, under a tropical sun," echoing Lieber's

\footnotetext{
${ }^{109}$ Theodore Dwight Woolsey, Political science: Or, The state Theoretically and Practically Considered (New York: Scribner, Armstrong \& company, 1877), 261, 199-200.

${ }^{110}$ Quoted in Ross, Origins, 67.
} 
own notion that liberty was properly articulated only in nations that developed according to fixed historical laws by institutions made up of disciplined intellectuals. ${ }^{111}$

But perhaps the most famous and significant champion of Lieber's Teutonism was Herbert Baxter Adams. A student of Bluntschli, Adams studied history and political science at Heidelberg; he served as a fellow at Johns Hopkins from 1876-1883 and as professor of American and Institutional history from 1883 onward. In 1884, Adams and White established the American Historical Association, the first of a long line of institutions to break away from the ASSA, with the intention of better blending the "union of History and politics" which "Bluntschli and Lieber, Arnold and Freeman regarded as inseparable."112 While ASSA members like Godkin sought to distance themselves from historicist notions of state formation, the new political scientists, who used the university to pare off from "activist" liberals and social reformers, embraced Whig historicism as a way of elevating their disciplinary practices to the level of scientific certainty, and to the center of the management of the nation-state. It was not a coincidence that the historicopolitical approach of those early political scientists, who were so overtly concerned with articulating the formation of the state and the proper foundations of their authority, would come to dominate the liberal imagination of internationalism in the US at the turn of the century.

\footnotetext{
111 Nicholas Guyatt, "America's Conservatory: Race, Reconstruction, and the Santo Domingo Debate," Journal of American History 97 (2011): 974 -1000.

${ }^{112}$ Cited in Ross, The Origins of American Social Science, 69.
} 


\section{Conclusion}

Throughout the Reconstruction and Gilded Ages, American social science and internationalism developed as relational conceptual and institutional structures. Much of the literature on the emergence of the social sciences in the US has focused on the role of liberalism in America's post-bellum social and political order, elucidating how this order was reflected by institutional formations in the social sciences like the American Social Science Association (ASSA). As this chapter has shown, however, liberal internationalism developed relationally to the social sciences, its ideational and institutional structure shifting to fit a changing ontology of the state increasingly generated by the social sciences and their various cognate fields.

The dominant concept of internationalism in America following the Civil War to the early 1870 s adapted to the challenges of local pressures and was, in substantial part, an attempt by a new reforming class to reconsolidate their authority around the social institutions at their disposal by carving them off as uniquely civic. But as liberal social scientists worked to thrust themselves to the center of the American nation, pulling the authority of government away from the state and into social and civic institutions, they were also adapting to discursive pressures over which they had little control. Social scientists' claims of articulating liberty and managing the political economy of the US were particularly constrained by two alternately clashing 
and complimentary discourses of exceptionalism, which had long animated the idea of America as an exceptionally stateless or weak-state society.

Throughout the 1870s, two variants of liberal internationalism emerged: the social and the civic. Both shared a faith in social science as the base instrument for guiding government, and both imagined society as the proper foundation of sovereign and state authority. But these two threads of liberal internationalism varied over what role the territorially-sovereign state played in working with the civic-institutions that gave articulation to the social world. In the period between the close of the Civil war and the Paris Commune in 1871, internationalism in the US veered towards a more broad social foundation, increasingly understood as a bourgeois form, where trained professionals and middle-class experts imagined their knowledge as the sinew of international society. Social science institutions like the SSA and AIPSS became models for liberal reformers around the world, proposing that civic organs could dissolve the power of states and bring populations together at a social level that appeared un-imperious and would cultivate civic institutions. This early internationalism revolved around and created professional structures of international law societies and jurists working out of, or closely aligned with, transatlantic social science organizations. It attempted to challenge the diplomatic-legal structures that had existed since the Peace of Westphalia with an alternative world-system, in which qualified authorities used social science to channel popular opinion and articulate civil liberty into institutions and laws for all states to obey. 
However, as the crisis of the Paris Commune and the threat of international labor unrest rose, liberal social scientists across the West moved quickly from a statist concept of internationalism in which law ameliorated the distinct power of sovereign, largely monarchical and autocratic states, to a concept of civic internationalism that treated the sovereign state as integral to the protection of a social order that, in turn, could spread itself without the state. Constrained by an entrenched national exceptionalism, post-Commune legal internationalists built on Lieber's legacy, emphasizing that national sovereignty resided in social alignments and institutions with the exceptional ability to articulate liberty, not only for the American nation, but also for the world at large. The shift was a simple one: where once liberal internationalists believed that sovereignty was a finite means to a cosmopolitan end, where nation states were subsumed and replaced by shared juridical institutions above and beyond the state, after 1871 state sovereignty was increasingly treated as an infinite and definite means to the spread and preservation of liberalism across the world.

For the overwhelmingly middle-class, Anglo-American social scientists at the vanguard of calls to economize government and check the power of the state, it was not a coincidence that such calls simultaneously vaunted their own norms and standards to the position of social laws that would form the basis of internationalism. Like their British liberal counterparts, social scientific reformers were not so much intent on displacing the state as they were on objectifying a particular state-social distinction that placed their 
social scientific expertise at the nexus of reform of the nation and the state. However, treating laissez-faire liberal principles as the social and historical basis of liberty in the nation, and therefore the most accurate reflection of popular opinion, had different consequences in the US than in Britain. Rather than having to balance these forces against the goal of removing aristocratic control of the state, American social scientists were much more preoccupied with socialism as a threat to America's liberal and republican institutions, those which allowed many to vaunt the US as a shining beacon of liberty for the world to follow. American social scientists' attempts at reform are easily seen as attempts to more firmly embed an already powerful social stratum within the mechanisms of the state, while simultaneously developing policies in organizations that were seen as external to the state but which still wielded an immense influence on law and policy that would direct the state's power. Internationalism played an important supporting role in helping social scientists illustrate how liberal institutions and practices ensured stability not by enforcing norms and standards through the state, but by enforcing them through civic or social intermediaries that could assure the most efficient and realistic governance by managing, maintaining and bridging the gap between the state and society. 


\section{Chapter Three: \\ "A Mandate From Humanity": Disciplining Social Science and Internationalism, 1880-1905}

\section{Introduction}

Andrew Dickson White sat in his personal library at Cornell University, warmed by a blazing fire as a winter storm howled off the tip of Cayuga Lake. Now in his early sixties, White had led an impressively accomplished academic and political life. ${ }^{1}$ Shortly after settling down to his daily routine that day in December 1895, a courier interrupted him with a confidential note from the Assistant Secretary of the Treasury of the United States. It kindly requested that White agree to join a government commission, called together by thenPresident Grover Cleveland, to settle a lingering dispute over the proper boundary between Venezuela and British-Guiana. A year earlier, few would have cared about the matter. But now it "had attracted great attention, not only in the United States, but throughout the world."2 For years the Venezuelan government had requested that the boundary be settled, appealing first to the British and by the 1880 s to America. With the help of recently hired American lawyer-lobbyists, Venezuela's government argued to the American government and people that British encroachments onto newly

\footnotetext{
${ }^{1}$ White had been a student of Francis Lieber's at Yale, later studied with Leopold von Ranke at the University of Berlin, and at the Sorbonne and Collège de France (1853-54), then sat as Professor of English and History at University of Michigan (1858-63) and became a senator (1863-65). After the Civil War, White served as the founding president of Cornell University (1866-85), served on the mostly ignored Commission to Santo Domingo (1871), sat as US ambassador to Germany (1879-81) served as the first President of the American Historical Association (1884-86), and was ambassador to Russia (1892-94).

${ }^{2}$ Andrew Dickson White, Autobiography of Andrew Dickson White (Cambridge: Harvard University Press, 1905), 117.
} 
discovered gold-fields were not only a breach of Venezuelan sovereignty, but also challenged the 70-year-old Monroe Doctrine-which proclaimed America would not tolerate any future colonization by European powers in the Western Hemisphere. ${ }^{3}$

Less than a year had passed since a congressional resolution calling for arbitration over the border received unanimous support. In the six months before White received the letter, Cleveland's Secretary of State, Richard Olney, sent a brash message-which he and Cleveland called the "twentyinch gun"- to the British, invoking the "safety" and "honor" of the United States. They received an equally brash reply, rejecting the notion that a thirdparty state had any say in the British Empire's affairs, and denying the applicability of the Monroe Doctrine to this dispute. ${ }^{4}$ Faced with the choice of backing down or starting a distant war over a little-known border where America's elite had few commercial and strategic interests, Olney dodged the horns and announced a unilateral investigative commission. With jingoistic calls for war growing louder, Cleveland dispatched three prominent lawyers and two university presidents (White and his old Yale roommate, Daniel Coit Gilman) to address the "jungle of geographical and legal questions"

\footnotetext{
${ }^{3}$ White, Autobiography, 117-130. For the then widely read work of legal-lobbyist, William L. Scruggs, making the case for American intervention see William Lindsay Scruggs, British Aggressions in Venezuela: Or, The Monroe Doctrine on Trial (New York: The Franklin printing and publishing co., 1895).

${ }^{4}$ Gerald G. Eggert, Richard Olney: Evolution of a Statesman (University Park: Pennsylvania State University Press, 1974).
} 
confronting Washington. ${ }^{5}$

The first two sessions, White would recall years later, were "fought over in a legal way," debating the almost 250-year-old Treaty of Münster, in which the Dutch and Spanish had "settled" the boundary in a single clause that gave the Dutch (whose territory had later passed to Britain) the right to "carry on warlike operations against certain other people." After hours of disagreement over this single clause and whether the "other people" referred to the native "Caribbean Indians" or Brazilians, White interjected. This "was a historical, and not a legal, question" that "could not possibly be settled by a legal argument". If the commission was to do its job, he proposed it would have to first explain why the clause had been inserted in the treaty; to do so necessitated knowing "the whole history leading up to it," and "who those "other persons" thus vaguely referred to...might be." White "insisted that this, being an historical question, must be solved by historical experts." 6

With the commission's approval, White contacted former student and still close administrative and academic assistant George Lincoln Burr, a fellow social science professionalizer of the historico-political school in vogue in many of the world's most prestigious universities. "The facts," White wrote to Burr, "can only be determined by a clear knowledge of the history of the

\footnotetext{
${ }^{5}$ For jingoism see Stuart Anderson, Race and rapprochement: Anglo-Saxonism and Anglo-American Relations, 1895-1904 (Rutherford, N.J.: Fairleigh Dickinson University, 1981), 97. For list of Commissioners see White, Autobiography of Andrew Dickson White, 119.

${ }^{6}$ White, Autobiography of Andrew Dickson White, 117-118.

${ }^{7}$ Dorothy Ross, "Anglo-American Political Science, 1880-1920," in Modern Political Science: AngloAmerican Exchanges Since 1880, ed. Robert Adcock, Mark Bevir, and Shannon C. Stimson (Princeton: Princeton University Press, 2007), 23.
} 
period, as bearing on the Treaty." 8 Working with two other prominent professional historians and colleagues from the American Historical Association, J. Franklin Jameson and Justin Winsor, Burr created a formidable report that drew on maps and diplomatic documents uncovered in the Library of Congress and the Library and Archives of the Hague. ${ }^{9}$ With the guidance of Gilman, a trained Geographer, the commission arrived at a boundary line and learned that the Court of Arbitration in Paris, convened after the British had agreed to arbitration in 1896, had recently arrived an almost identical boundary. The commission never formally proposed the boundary the determined, instead supplying an atlas and fourteen volumes containing many of the documents, treaties and maps it had unearthed.

Historians have long treated the Venezuela Boundary Dispute and the rapprochement between Britain and the US as a seminal event in American diplomatic history. It is generally agreed that the crisis was geopolitically significant because it signaled that the American state was willing and able to exert its fiat over the Western hemisphere. This heralded the US as a "world power," and also created a convenient alliance between the US and UK, as the former effectively became the dominant colonial-police power in regions that a retreating British Empire strained to keep out of the hands of rival powers. ${ }^{10}$

\footnotetext{
${ }^{8}$ White, Autobiography of Andrew Dickson White, 199-120; A.D. White to G.L. Burr, 2 March 1896 (box 74), Andrew Dickson White Papers (\#01-02-02), Division of Rare and Manuscript Collections, Cornell University Library. (Hereafter refered to as White Papers)

${ }^{9}$ George Lincoln Burr, "The Search for the Venezuela-Guiana Boundary," The American Historical Review 4 (1899), 470-477.

${ }^{10}$ For summaries of US foreign relations historiography on this period see, Edward P. Crapol, "Coming to Terms with Empire: The Historiography of Late Nineteenth Century American Foreign Relations,"
} 
Cultural histories have noted that the crisis and debates around international arbitration cemented a once-buried cultural affinity between the two nations. "Anglo-Saxonism" became a powerful way of articulating a sense of "racial brotherhood," adapting the language of Darwinism to justify America's foray into formal state-centered imperialism in $1898 .{ }^{11}$ Perhaps the most lasting assessment of the crisis, however, came from New Left historians who emphasized it as one way-point in a larger and ongoing economic expansion of American commercial and financial interests, extending America's economic reach and quelling the endemic concern with overproduction and market stagnation. ${ }^{12}$

This chapter proposes that the Venezuela Commission, if viewed through the lens of the relational development of the social sciences and internationalism, be understood as another event that highlights the how internaitonalism reflected the alignment of certain kinds of knowledge and disciplines in American social science. White and the host of academics he

Diplomatic History 16 (1992): 573-598; James A. Field, “American Imperialism: The Worst Chapter in Almost Any Book," The American Historical Review 83 (1978): 644-668; Hugh DeSantis, "The Imperialist Impulse and American Innocence, 1865-1900," in American Foreign Relations, A Historiographical Review, ed. Gerald Haines and Samuel J. Walker (Westport, CT: Greenwood Publishing, 1981). For contemporary account that draws this geopolitical concern into the same frame as other cultural, intellectual and economic changes see, Thomas McCormick, "From Old Empire to New," in Colonial Crucible:

Empire in the Making of the Modern American State, ed. Alfred W. McCoy and Francisco Antonio Scarano (Madison: University of Wisconsin Press, 2009), 67-68.

11 Anderson, Race and rapprochement, 95-111; also see Paul A. Kramer, "Empires, Exceptions and AngloSaxons: Race and Rule between the British and United States Empires, 1880-1920," Journal of American History 88 (2002): 1315-1353.

${ }^{12}$ See Walter LaFeber, The New Empire: An Interpretation of American Expansion, 1860-1898 (Ithaca: Cornell University Press, 1998); William Appleman Williams, The Tragedy of American Diplomacy (New York: W.W. Norton, 1988). For a modification of the Open Door to a global World System argument that emphasizes the continued importance of economic factors in this period see, Joseph A. Fry, "From Open Door to World Systems: Economic Interpretations of Late Nineteenth Century American Foreign Relations," Pacific Historical Review 65 (1996): 277-303. 
called to deliver "the facts" to the commission, I argue, must be seen as exemplifying a shift in expert authority and the disciplining of knowledge in the social sciences available to conceptualize internationalism. They shifted from civic foundations, most commonly found in shared juridical institutions and restricted to "civilized" nations, towards more encompassing social scientific foundations, which imagined the world as already united by social forces waiting to be formalized in government apart from the nation-state. White's insertion of the expertise of disciplinary history and geography into what was otherwise a legalistic and diplomatic dialogue hints at how shifting institutional and methodological alignments in the social sciences were shaping and being shaped by a grappling with how to best govern the international sphere in this period. The professionalization, disciplinary fragmentation, and movement of the social sciences into the modern, and now industrially funded university had a very real effect on the concept of internationalism in America. This chapter proposes that internationalism was modified and (re)-articulated to reflect particular interpretations of the state, society, and the boundary between them leaving intact American exceptionalism as the core of the rationalization of governance in American thinking.

For the circle of historico-political scientists that radiated out from Lieber following the American Civil War (see Chapter Two), and who believed America an exceptionally stateless society that had achieved democracy through the nurturing of Anglo-Saxon civic institutions, it was 
apparent that state-sovereignty had to be the end and the means of liberal international development. By the 1880 s and 1890 s, however, the institutional and intellectual foundations of social science were shifting, placing new pressures on the dominant political economic consensus, as intellectuals adapted their work to the rapid changes of a more self-consciously globalized American society. The conception of liberal internationalism followed this shift. But as this chapter shows, it was contested as a concept and a series of related practices in the final quarter of the 19th century. Competing concepts of the state-differing over its distinction from society, the role of certain civic institutions in maintaining that split, and the universality of the nation-state as the primary unit in an international system-meant the social sciences were conceived of in different intermediating capacities that depended greatly on one's view of what the international was and how it ought to be governed.

To illustrate this I first look at the emergence of the Washington Circle of social scientists, exploring the early emergence of a modified liberal political economy, in the work of Francis Walker, and positivism, embodied in the likes of Lester Frank Ward, to view the nation-state and international governance as guided by social principles that were universal, rather than the expression of class interests, so long as they strove with the state to achieve egalitarian ends. Following from this, I explore a series of debates between the professional social scientists in the Washington Circle and the ASSA and both the famous socialist author Matthew Bellamy and the economist Henry George. Using these debates over the role and shape of nation-state, as well 
as the political economic principles at the base of international trade and conflict resolution, I propose that we are able to see the emergence of a liberal internationalism that-in adapting and subsuming the criticisms of American socialists in the 1870 s and 1880 s-imagined an international system built around a more active role for the state where social scientists guarded against unacceptable imbalances in power or wealth by directing the resources and energy of the state towards more egalitarian ends.

Next, carrying forward the shift towards historical and geographical knowledge made visible by the story of White's intervention in the Venezuela boundary dispute, I show how social science and internationalism were again adapted to make sense of the challenges presented by America's foray into formal state-centered imperialism in the late 1890s.

The civic internationalism that dominated the immediate post-Civil War period particularly after the hysteria of the Paris Commune, fragmented as a reaction, into two competing but interconnected liberal variants. The first was an altered civic internationalism, and the second was a more encompassing social internationalism. The social internationalism that splintered from its civic counterpart also placed non-state institutions at the vanguard of its brand of internationalism. But unlike civic internationalism, it peopled those institutions with experts on the social world as a varied but still unified whole-positivists who believed it possible to understand the social world with scientific certainty, and that civic institutions (such as juridical, educational and political institutions) were local, situated, and therefore 
biased. In other words, for social scientists, civic institutions could not by definition play the role cut out for science, and became only one part of a larger social sphere. Not only did this subsume the civic under the social; the state also became a structure linked to particular sociological and historical conditions. While they varied over what knowledge best directed the state and society, and what institutions embodied that knowledge, with the overseas expansion of American empire in 1898-1902 both internationalisms emerged with a shared ontology of the nation that imagined the state and society as separate and the emergent social sciences, though with different disciplinary rationalities, as integral to spreading liberalism across the world.

\section{The Washington Circle and the Foundations of Social-Liberal}

\section{Internationalism}

One of the most significant tempering forces on the historico-political tradition that radiated out from Lieber in the early Gilded age came from the work of Francis Amasa Walker, Lester Frank Ward, and a small but influential circle of Washington-based social scientists. Working from the beach-head of the Smithsonian Institute, Ward, Walker, John Eaton, John Wesley Powell, and Carroll D. Wright took a leading role, in Michael Lacey's words, in "establishing important scientific agencies of a larger, more purposeful and 
progressive post-bellum government." ${ }^{13}$ As it had been with the historicopolitical school, the Civil War was formative for these men. They lost much of their distrust of federal state-centered governance, and imagined the new secular authority of social science playing a chief role in reforming society through federal bureaus, reports, and institutes such as the Smithsonian. ${ }^{14}$ Save for Ward, all the major members of the Washington circle would hold high positions in the ASSA, and would walk between Washington and New England with great ease. But what differentiated the Washington circle that developed in the 1860s and 1870s from most of their ASSA counterparts was a desire to professionalize social science around the state rather than civichumanitarian institutions.

Their vision of professionalizing the social sciences within apparatuses of the state nevertheless made the Washington circle strong allies of the ASSA, especially on the matter of civil service reform. Indeed, with the Civil Service Reform Act in 1883, their vision gathered substantial momentum, helping

\footnotetext{
${ }^{13}$ Michael J. Lacey, "The World of Bureaus: Government and the Positivist Project in the Late Nineteenth Century," in The State and Social Investigation in Britain and the United States, ed. Mary O. Furner and Michael J. Lacey (New York: Cambridge University Press, 2004), 129.

${ }^{14}$ Adapting Richard Hofstadter's concepts of social and reform Darwinism to observations that the post Civil War period saw new institutions and secular forms of knowledge emerge, many have assumed that Darwinism was integral to a revolution in the sites of social authority, moving away from religion and towards a more scientific order. But, as a substantial body of literature has well documented, protestant and particularly egalitarian reformers were often among the staunchest advocates of Darwinism and on the front line of adapting it to broader social theory and governance. It is beyond the scope of this thesis, but while the language used to articulate social order may have shifted towards a more secular vernacular, just as Max Weber noted of the protestant work ethic, the dilution of religious language did not mean that the values and hierarchies of religion were removed altogether. Rather, religion continued to play a prominent role informing articulations of egalitarianism and hierarchy even with Darwinism. Ronald L. Numbers, Darwinism Comes to America (Cambridge: Harvard University Press, 1998), 23-26. Also see James R. Moore, The Post-Darwinian Controversies: A Study of the Protestant Struggle to Come to Terms with Darwin in Great Britain and America, 1870-1900 (New York: Cambridge University Press, 1979); David N. Livingstone, Darwin's Forgotten Defenders: The Encounter between Evangelical Theology and Evolutionary Thought (Edinburgh: Scottish Academic Press, 1987).
} 
them create, according to Lacey, a vast and "complex structure of institutions, public and private." 15 The United States National Museum, U.S. Geological Survey, Bureau of Ethnology, U.S. Weather Bureau, Bureau of Forests, Biological Survey of the Department of Agriculture, the foundation elements of the U.S. Fish and Wildlife Service, Department of Education, the Bureau of Labor Statistics, and by the turn of the century a permanent Bureau of Statistics, were all legacies of this small circle of Washington reformers, loaning substantial scientific weight to the work of the ASSA, even as many in the ASSA sought to minimize the reach and capacity of the state. ${ }^{16}$

While some remained doggedly wed to laissez-faire liberalism, the new liberalisms that were articulated by those thinkers in Washington were markedly different and helped pave the way for new concepts of social scientific specialization and internationalism. As others have noted, the Washington circle did not seem to "harbor the same fear of democratic participation that many of the genteel reformers did, and they harbored no pessimism about the nation's future."17 For the Washington men, their work measuring the data that would manage and represent the nation created a unique "understanding of the relationship between government and the state and between the individual and society," which rested more "squarely on the republican tradition, which required a virtuous and knowledgeable citizenry

\footnotetext{
${ }^{15}$ Lacey, "The World of Bureaus," 130-131. Furner, Advocacy and Objectivity, 42-44.

${ }^{16}$ Lacey, "The World of Bureaus," 129.

${ }^{17}$ Edward C. Rafferty, Apostle of Human Progress: Lester Frank Ward and American Political Thought, 1841-1913 (New York: Rowman \& Littlefield, 2003), 10.
} 
for the continued progress of American institutions." 18

Figures like Walker, who headed the 1870 and 1880 censuses, and who "picked up on the strain of moderate criticism already at work in English economists seeking to accommodate their discipline to industrial protest," worked to establish governmental practices inside the state and in political economy that would gradually furnish "society with the knowledge of social and economic conditions that could provide for the progress and health of the state."19 As Matthew G. Hannah has argued, Walker was a particularly poignant model of how the Washington reformers distinguished "between restrictive and coercive regulation and supportive or fostering regulation," imagining a more subtle but still nascent politics of regulation that created disciplined, self-governing citizens. Indeed, Walker noted in an 1887 essay on socialism that the state could certainly play a "leadership" role that complemented the private sphere to "stimulate individual action," but he imagined workers and capital as bound in a relationship of consent and mutual interest. ${ }^{20}$ The distinction between government and the state for the Washington men was roughly similar to their distinction between individual and society. "Government was a component part of the state just as the individual was embedded in the larger society," so that the state was defined as the whole social order, or, as Lacey puts it in summarizing the arguments of

\footnotetext{
${ }^{18}$ Ibid.

${ }^{19}$ Ross, Origins, 82; For more on this also see, Rafferty, Apostle of Human Progress, 10.

${ }^{20}$ Matthew G. Hannah, Governmentality and the Mastery of Territory in Nineteenth-Century America (New York: Cambridge University Press, 2000), 188-190; Francis Amasa Walker, "Socialism," Scribner's Magazine 1 (1887): 107-119.
} 
John Wesley Powell, "the combination of public and private agencies that made up the organizational structure of society."21

The ability of the Washington men made them ideally suited to move seamlessly between work in the "hard" or physical sciences (such as geology or biology) and social reform, public bureaus and private associations. This attracted Lester Ward, who did not have the patrician upbringing of Walker and Carroll Wright but shared their fusion of "liberal faiths in freedom and self-rule and the republican faith in virtue and responsible citizenship."22 As Ross has noted, his background was a "product of the improving Whig culture in its most egalitarian form," and his early attempts at articulating an intellectual space for sociology in his influential Dynamic Sociology (18831897) reflected this in its "artisanal strategy of self-help," which treated education as the ultimate means to individual liberty and social cohesion. ${ }^{23}$ Ward entered the Geological Survey under the watch and influence of Powell in 1875, and refined his work on the virtues of education and the place of the state reconciling access to free markets with the societal goal of a more egalitarian society. Ward rejected the political ethics of Herbert Spencer, which he would later say imparted "the character of a gospel of inaction." 1 Instead he turned to Comte's stages of sociological development, which distinguished between natural and social development, held that human

\footnotetext{
${ }^{21}$ Lacey, World of Bureaus, 135; Rafferty, Apostle of Human Progress, 10.

${ }^{22}$ Rafferty, Apostle of Human Progress, $10-11$.

${ }^{23}$ Ross, Origins, 89.

${ }^{24}$ Lester F. Ward, "The Political Ethics of Herbert Spencer," Annals of the American Academy of Political and Social Science 4 (1894): 127.
} 
action could direct the forces of progress, and imagined the latter culminating, via a progressively educated population, in a "sociocracy."

"Sociocracy" provided a foundation for a substantial re-articulation not only of liberalism, as it was imagined in the new social science of sociology, but also of liberal internationalism. While the laissez-faire intellectuals of the ASSA had imagined social order held together by civic institutions that circumscribed normative social laws, Ward imagined that educated, scientific minds could lead the cause of reform by innovating techniques of government and inserting them into the state's regulatory apparatuses. His admission that real psychic and institutional structures-not least his contemporaries' faith in laissez-faire economics-constrained social reform, was not an admission that reform was impossible or undesirable (as his intellectual foil, William Graham Sumner argued it was). ${ }^{25}$ Ward's time in Washington circles convinced him that "government power must have a hand in social change or the damages of rampant growth threatened to tear apart the nation." It was not enough for political scientists to continue merely discussing the principles of government and politics as if they were timeless, normative forces. Rather, if one truly believed that a "scientific politics is theoretically possible," then the methods of invention used to arrive at these principles, and their application, would stand the test of experiment. And, because the only laboratory where one could test scientific principles of politics in a popular democracy was the state, it stood to reason that the state had an integral role to play in

\footnotetext{
${ }^{25}$ Ross, Origins, 91.
} 
governing. ${ }^{26}$

Like his Washington colleague, Wesley Powell, Ward saw the state as an essential site for the expression of cultural interconnectivity and identity. What Powell called the "grand unit of social organization," Ward called "the most important step taken by man in the direction of controlling the social forces." As Lacey notes, what was novel in this stance was "the refusal to recognize as the embodiment of special virtue either government or civil society at the expense of the other; instead the emphasis was on the combined effects of governmental and civil society in determining the overall condition of social order." The Washington circle differentiated between government and the state, but the latter was treated as "the more inclusive term roughly synonymous with 'the social order"', "pointing to a complex and compound structure of connections between public and private held together by the legal and regulatory operations of the former." Government was the sum of the means of regulation; "the institutions of civil society were subsidiary to it," but there were no hard and fast lines separating public and private. ${ }^{27}$ Sociological dynamics were too fluid and complex to be captured effectively in timeless political, legal, and economic doctrines, meaning that the state would constantly have to re-calibrate its governmental boundaries.

Ward's scientifically-guided state was anything but a radical or illiberal expression. Rather, he was careful to remain anchored to a Whig-liberal faith

\footnotetext{
${ }^{26}$ Lester F. Ward, "The Claims of Political Science," Science 72 (1884): 748.

${ }^{27}$ Lacey, "The World of Bureaus," 148, 160.
} 
that education could direct progress and move towards the harmonization of conflicting interests. As Ross notes, for Ward "there were no irreconcilable conflicts of interest or value that could not be harmonized by scientific rationality." 28 With the Commune in 1871, Ward's brother, Cyrenus Osborne Ward, had been arrested as a spy during the Franco-Prussian Wars and then joined Marx and Engels in the International Workingmen's Association. In response, Ward attempted to soften the radicalism of the Commune for his American audience. "The 'commune' movement appears to be a general rather than a national one, and is intimately connected to the International Workingmen's Association," he told his liberal colleagues and readers of The Iconoclast. With little patience for denunciations of the "terror" of the communards for their destruction of some significant landmarks in Paris, he argued, "few great and sudden changes in the organization of human society or government are achieved without sacrifice of life and property." $29 \mathrm{He}$ sympathized with the Commune, interpreting it as a localized effort to establish self-governance in the face of autocracy. For him, the insurgency was the manifestation of a global problem (not a uniquely French one as others had alleged) and could only truly be addressed by a more liberal and thorough education of citizens:

The word education embraces all those varied events, influences, fluctuations, and vicissitudes which surround and attend the life of every individual from cradle to grave...This

\footnotetext{
${ }^{28}$ Ross, Origins, 43.

${ }^{29}$ Timothy Messer-Kruse, The Yankee International: Marxism and the American reform tradition, 1848 1876 (Durham: Univ of North Carolina Press, 1998), 142-145.
} 
is the great truth of the century, the great balm of the wounds of the world, and the entering wedge which is to cleave asunder the mountain of wrath which society has been so long heaping over itself, and lay the foundations for that broad and exalted charity and that liberal ennobling education which are to go hand in hand and consummate edenization of the world. $^{30}$

Ward recognized the strife of the Commune as a symptom of large, modern forces, as part of a general desire to remake the very way that people constituted and thought about government, that was as apparent in 1870s and 80s America as it was in Paris. But conflict was not inevitable for Ward. Rather it proved the need to create a more flexible state that heeded calls for a more equal social order by incorporating methods and principles that could ameliorate social disorder and inequality. Implicit in his vision of the state, however, was an acceptance that the nation was the basic unit of governmental order, and the nation-state therefore a proper target of governmentalization.

This socio-political order reached far beyond its local or national context, however, interpreting international events as proof that scientific management of the state and society was a global solution that demanded coordinated international action. "Competing labor is everywhere compelled to contract on unequal terms with combining capital," Ward noted. But to bring these conflicting interests into harmony, people everywhere would have to admit that the state and government existed for the good of society

\footnotetext{
${ }^{30}$ Lester Frank Ward, Dynamic Sociology, or Applied Social Science: As Based Upon Statical Sociology and the Less Complex Sciences, V.1 [1883] (Ithaca: Cornell University Press, 2009), 196.
} 
and that "no power short of that of society itself, i.e., the State, can prevent this condition of things."31 Ward's positivism seems naively utopian about science's ability to solve the world's problems, but it was an expression of the larger scientific optimism of his time. Ward blended positivism with a republican belief in the virtues of a knowledgeable citizenry, and imagined development as a Whiggish progression towards an egalitarian utopia. Wards world was one guided by a scientific elite, and upheld through the broad education of the citizenry. The result of this complex of discourses was a unique articulation of liberal-internationalism that differed from the historicopolitical school that emerged from Lieber. Ward's vision of the international was an extension of his belief that liberal subjects, though anchored to forces of nature and bound by virtue, could act and think in ways that changed their social environment and, by extension, their states..$\left.^{32}\right\urcorner 7$

Unlike later generations that would tackle the question more directly,

${ }^{31}$ Ward, "The Political Ethics of Herbert Spencer," 121.

${ }^{32}$ For more on Ward's assertion that "society should imagine itself an individual see," Wilfred M. McClay, The Masterless: Self \& Society in Modern America (Chapel Hill: University of North Carolina Press, 1994), 120-136. Ward never explicitly discussed internationalism but he did offer thoughts on diplomacy.

Diplomacy, he argued, was a natural human capacity that was as apparent in person-to-person exchanges as it was in state-to-state relations. But, as a human behavior, diplomacy was pregnant with ethical choice. One could choose to work towards harmony by emphasizing the social interdependence of races and nations, or one could allow "ambitions" to triumph and give in to the illiberal "desire of the ruling class" to manipulate a people for selfish gain. Rulers and shrewd strategic politicians, Ward argued, are the ones who are treated as the fittest to survive from a "strictly biological standpoint ... Those, therefore, who teach sociology from the laws of biology should not only treat them as the highest types but should welcome them as the most perfect examples of social development." ${ }^{, 32}$ But Ward believed that the capacity for intuitive reason that made it possible to manipulate people like animals proved that diplomacy and human behaviour were not naturalistic but adaptive, at a social level related to nature but still distinct from it. Therefore there was as much a capacity for cooperative, diplomatic relations between nations as there was for acrimonious and manipulative ones - as with individuals - if built around shared social foundationsSee Lester F. Ward, The psychic factors of civilization (New York: Ginn \& Company, 1892), 154-161. Also see Lester F. Ward, "Contemporary Sociology. II," American Journal of Sociology 7 (1902): 637. 
Ward's internationalism was never explicitly elucidated in his work. Rather it developed as a corollary to his own attempts to create a local disciplinary space for sociology which he believed was, and did much to ensure became, an "international" movement that could facilitate progress towards sociocratic conditions where individuals understood their nation-states as a means to building their "distinct moral obligation towards the members of other races and nations." 35

\section{The Washington Circle and the Specter of Socialist Internationalism}

The liberals of the Washington circle, while skeptical of the metaphysics of laissez-faire individualism, were equally suspect of the collectivist abstractions that grew throughout the 1880s and 1890s. Walker was an especially vicious critic of American socialisms, tackling both the writer Edward Bellamy and the economist Henry George. Like Ward, Bellamy resented the chauvinism that certain belief systems engendered, and was especially scornful of the use of nationalism to breed the patriotism that suppressed humanity's larger social solidarity. "The sentiment of national solidarity," Bellamy argued, "was arrayed against the sentiment of human solidarity" so that "a lesser social enthusiasm was set in opposition to a greater and the result was necessarily full of moral contradictions. Too often what was called love of country might better have been described as hate and

\footnotetext{
${ }^{35}$ Ibid.
} 
jealousy of other countries." ${ }^{36}$ Bellamy's most famous work (and the third bestselling book in $19^{\text {th }}$-century America), Looking Backward, described a future utopia world composed of "New Nations":

The great nations of Europe as well as Australia, Mexico, and parts of South America, are now organized industrially like the United States, which was the pioneer of the evolution. The peaceful relations of these nations are assured by a loose form of federal union of world-wide extent. An international council regulates the mutual intercourse and commerce of the members of the union and their joint policy toward the more backward races, which are gradually being educated up to civilized institutions. Complete autonomy within its own limits is enjoyed by every nation ... Each nation has a bureau of foreign exchange, which manages its trading. For example, the American bureau, estimating such and such quantities of French goods necessary to America for a given year, sends the order to the French bureau, which in turn sends its order to our bureau. The same is done mutually by all the nations. ${ }^{37}$

Freed from industrial competition, exploitation, poverty, and unemployment, Bellamy imagined the New Nation as the core social solidarity and administrative unit in a larger socially-based internationalism, stripped of the imperialism and inequality that seemed to accompany international trade and globalizing capital. Bellamy's novels were remarkable because, though they advocated a socialized state as the sole controller of industrial and financial affairs, their utopianism expressed liberal and middle-class values, rather than working class or proletariat social consciousness associated with more radical socialisms. The "New Nation" would be, for the deeply Christian and

\footnotetext{
${ }^{36}$ Edward Bellamy, Equality [1898] (New York: Cosimo, Inc., 2008), 187.

${ }^{37}$ Edward Bellamy, Looking Backward (New York: Applewood Books, 2000), 145.
} 
egalitarian Bellamy, the product of a non-violent revolution that transformed America and the entire civilized world into a cooperative, liberal commonwealth where all individuals shared in the wealth of nations.

Perhaps because of the popularity of Bellamy's vision, reaction from the Washington circle was swift. Walker publicly castigated Bellamy for aiming at a utopian end that was neither achievable nor desirable. Although he understood the desire to grasp the growing challenges of industrial modernity, Walker cautioned a general readership, and fellow economists, of Bellamy's plan for a hyper-nationalized international:

[U]nexercised and unbreathed, we would reduce our descendants...to the moral state of the Polynesian. We know that it is of the very essence of social progress that as fast as we are released by arts, inventions and improved organization from cares and labors which have worn and wearied us, we should create for, ourselves new wants which shall take up all the time and strengths thus set free; and that it is not rest man needs, but work. ${ }^{38}$

More than most political economists of his time, Walker sympathized with the plight of labour unions and their distrust of crass laissez-faire economics. ${ }^{39}$ But for him the very conditions that created modern problems made simplistic, utopian visions all the more dangerous. He understood why a collective that "surrendered individuality with its anxieties and burdens" might seem appealing to those exhausted by or suffering from the malaise of the daily grind of modern life. But sacrificing those responsibilities risked sacrificing

\footnotetext{
${ }^{38}$ Francis A. Walker, "The Tide of Economic Thought," Publications of the American Economic Association 6 (1891): 175-178.

${ }^{39}$ Ross, Origins, 98-102.
} 
the individual's "glory and power, for an all-absorbing Nationalism." While burdensome, Walker proposed that it was global trade and free markets that had created, or were creating, the material and commercial conditions that made possible the international social intercourse that Bellamy believed to be the core of internationalism. ${ }^{40}$

Walker's distrust of "simplistic," standardized solutions that used the state to solve international problems also took aim at the hugely popular economist Henry George. George drew international attention for his 1879 work Progress and Poverty and was a world-renowned figure by 1885 . If polemical in his diagnosis and prescriptions for the social ills endemic to capitalist economies, George was hardly a radical. On the contrary, he maintained a faith in competitive private enterprise and saw no inherent injustice or conflict between labor and non-monopolized capital. ${ }^{41}$ What made Walker uncomfortable with George's work, however, was its "attack on landed property" and the strong interest his ideas generated in the US, Britain, and across Western Europe.$^{42}$ What is perhaps most remarkable about the economic theory behind George's Single Tax and the political movements that took it on, for our purposes, is that in dismissing George's calls for land reforms and taxation, Walker followed the lead of other professionalizing economists, blaming George's amateurism for his failure to recognize

\footnotetext{
${ }^{40}$ Francis A. Walker, "The Tide of Economic Thought," 178; Edward Bellamy, "Looking Backward" Again," The North American Review 400 (1890): 351-363.

41 John K. Whitaker, "Enemies or Allies? Henry George and Francis Amasa Walker One Century Later," Journal of Economic Literature 35 (1997): 1897.

${ }^{42}$ Francis A. Walker, "Henry George's Social Fallacies," The North American Review 321 (1883), 149.
} 
problems as the product of global forces which thus require a global solution.

George had already faced the collective wrath of professional and conservative economists at the 1890 Saratoga meeting of the ASSA. There, E.R.A. Seligman said in a debate with him that, "there is not a single man with a thorough training in the history of economics, or an acquaintance with the science of finance, who is an advocate of [George's] single tax on land values." Seligman flippantly noted that "in biology, in astronomy, in metaphysics, we bow down before the specialist [...] but every man whose knowledge of economics or of the science of finance is derived from the daily papers, or one or two books with lopsided ideas, thinks that he is a fulledged scientist, able to instruct the closest student of the markets or of the political and social organisms." George fired back that Seligman's authority was not derived from specialized expertise but was the product of a professionalism developed in a university system dominated by vested interests. "You must choose between the single tax," George warned the ASSA, "with its recognition of the rights of the individual, with its recognition of the province of government, with its recognition of the rights of property, on the one hand, and socialism on the other." 43

Walker claimed that he was happy to witness the popular surge in what he called the "Tide of Economic Thought," a tide that expanded the boundaries of political economy in the 1880 s to include a more regulatory

\footnotetext{
${ }^{43}$ Robert V. Andelson and Mason Gaffney, "Seligman and His Critique from Social Utility," American Journal of Economics and Sociology 62 (2003): 407-432.
} 
state. But, by the same token, he worried that the popularity of works like Bellamy's and George's, alongside the swell of William Jennings Bryan, Silver standard crusaders, Christian socialism, agrarian populism, and national protectionism, revealed that "crude thinking" was taking hold in the "cultivated classes" of America, and especially among the new "immigrant stocks," and risked sweeping away real reformers. ${ }^{44}$ As Thomas Bender noted of the rise of social liberalism as an international movement, the "sharp dividing line between socialists and liberals" once imagined in historical work has given way in our time to a more nuanced sense of the "border crossing or even collaboration" between these camps.7 Walker and the rest of his colleagues were very much aware of the radical variants of socialism that threatened autocratic and liberal nations across Europe, and were no doubt relieved that these various movements "emphasized ethical reform rather than revolutionary political action." ${ }^{36}$

The point is that Walker's rejection of Bellamy's "nationalist" collectivism and his dismissal of George as an amateur, held alongside his simultaneous emphasis on expanding the capacities of the state through reason rather than ethical impulses, revealed a new conception that would become more prominent in the 1880s and 1890s of from whence and from whom reforms should emanate.

\footnotetext{
${ }^{44}$ Francis A. Walker, "The Tide of Economic Thought," 355.

${ }^{45}$ Bender, A Nation Among Nations, 269.

${ }^{46}$ Kloppenberg, Uncertain Victory, 207.
} 
The Changing Domain of Political Economy: New Disciplines, New Institutions, and New Internationalism

By 1879 , the domain of political economy that had provided the guiding intellectual principles for the American social science and the ASSA, as Nancy Cohen has shown, had become vastly more complicated, "as the depression of the seventies had triggered doubts about accepted axioms and spawned new forays in economic history." 47 As explored in the last chapter, Lieber's intellectual descendants had begun to develop a distinct political scientific tradition, breaking with international social science organs and advocates of legal codification, more tightly connecting their work to the ASSA and focusing on reforming the nation. With questions of "government" and the "state" as their central epistemological problematic, the historico-political reformers that helped develop the ASSA proposed a legalistic form of internationalism that complemented their faith in Manchester political economy because it treated liberal civic institutions as the proper, historically developed, foundations of America's exceptionally minimal state.

In the history of the American social sciences, the most widely discussed path away from this laissez-faire doctrine in America has focused on the development of a new form of political economy via the professionalization of university academics who received their formal graduate training in Germany in the 1880s and 1890s. Returning from Europe and immediately setting to work on a professional association along the lines

\footnotetext{
${ }^{47}$ Cohen, Reconstruction of American Liberalism, 143.
} 
of the German Verein für Sozialpolitik, these younger economists launched an immediate assault on laissez-faire. ${ }^{48}$ The platform of the AEA, founded in 1885, declared that the "conflict of labour and capital" had brought on a "vast number of social problems." As Richard T. Ely, among the most prominent of the young German-trained insurgents, would recall years later, they were part of a revolt against "the sterility and barrenness of the old economics," a "protest ... against the current political and social ideas." ${ }^{49}$ Ely's 1884 work, Past and Present Political Economy, was perhaps the loudest and most direct shot across the bow of the aissez-faire school in American social scientific circles. $^{50}$ The "old" political economy, he proposed, was deductive, hypothetical and abstract, and it elevated base emotions such as selfishness in order to sanctify unfettered competition. The "new" political economy, on the other hand, possessed an historical sensibility about the state as a social force, which could be used to advance the people's interests through positive liberty. Not insignificantly, Ely's attack earned a response from a bulwark of the ASSA community, Simon Newcomb, author of Principles of Political Economy (1885), and a professional mathematician and astronomer at the newly minted Johns Hopkins University. Newcombe ably defended British political economy, but did it, perhaps unsurprisingly, without any

\footnotetext{
${ }^{48}$ Furner, Advocacy and Objectivity, 35-58; Bender, A Nation Among Nations; 263-264; Daniel T. Rodgers, Atlantic Crossings, 85-97; Ross, Origins, 100-103.

${ }^{49}$ John G. Gunnell, "The Real Revolution in Political Science," PS: Political Science \& Politics 37 (2004): 47-50; Ely, 1910, 69-80, Cited in Cristobal Young, "The Emergence of Sociology From Political Economy in the United States: 1890 to 1940," Journal of the History of the Behavioral Sciences 45 (2009): 91-116.

${ }^{50}$ Furner, Advocacy and Objectivity, 60; Joseph Dorfman, The Economic Mind in America, Vol. 3 (New York: A. Kelley, 1969), 205.
} 
qualifications or restrictions such as those Mill's Unsettled Questions had made clear in the British context more than a decade earlier. ${ }^{51}$

Much has been made of this conflict between the German-trained "ethical economists" and the old guard of genteel laissez-faire reformers, many still working closely with the ASSA, who exerted a disproportionate institutional influence throughout the 1880 s and into the 1890s. Cohen has noted that the younger generation of social scientists, which included Ely, Simon Patten, Henry Carter Adams, E.R.A. Seligman, John R. Commons, and John Bates Clark, would eventually "redirect the main current of social theory, especially in political economy." But "the older generation of liberal reformers wielded sufficient power to steer their challengers back onto terrain more favorable to the survival of their core liberal values. ${ }^{52}$ As other historians have shown, the ethical economists' pro-labour and quasisocialistic stances were especially easy to soften because the older generation was shifting the center of professional prestige in the social sciences into modern university chairs. This did not bode well for those who sympathized openly with labour. As the fortunes of the Carnegies, Rockefellers, Cornells, Hopkins, Clarks, Vanderbilts, Stanfords, and other industrial and new corporate barons funded the construction of new and cutting-edge research institutions, public institutions recently started under the Land-Grant system "mimicked them, and the older traditional colleges,

\footnotetext{
51 Peter T. Manicas, "The Social Science Disciplines," Discourses on Society 15 (1990): 59-60.

${ }^{52}$ Cohen, The Reconstruction of American Liberalism, 1865-1914, 148.
} 
Yale, Harvard and Columbia." In so far as they competed for students and status, and were beholden to state legislators and voters, higher-education funding was increasingly structured around the values and priorities set by an emergent corporate liberal class even if now administered by a group of new university reformers..$^{53}$

Against this backdrop, the ethical economists who returned from Germany and identified with working class causes were forced either to soften their positions publicly on socialism and communism or to be pushed out of academia altogether. John Bates Clark was among the first to retreat from socialism after the Haymarket riot in May of 1886 sent shockwaves through America's upper and middling classes. ${ }^{54}$ But among the most famous defections, and perhaps the one most plainly spurred by industrialist interests, was Henry Carter Adams. Adams strongly supported labour and saw the dogmatic defense of private property as problematic for American social order, proposing that "private property which affects the lives of others and exerts a public influence must be subject to public regulation." Split between lectureships at Cornell and Michigan, Adams posed his reading of private property in a public lecture where one of Cornell's influential benefactors heard his interpretation and sent letters objecting to the young economists radicalism. Adams, in turn, received letters from both university presidents asking him to clarify his "leanings." The young and still

\footnotetext{
${ }^{53}$ Manicas, "The Social Science Disciplines," 60.

${ }^{54}$ Dorothy Ross, "Socialism and American Liberalism: Academic Social Thought in the $1880 \mathrm{~s}$," Perspectives in American History 11 (1978): 35-42.
} 
professionally insecure economists retreated on his interpretation of property rights, and away from his claim that the "State should control labor relations" and enter "into the realm of experts and individualism." After reassuring the President of Michigan, he received his tenure. At the University of Chicago, under the presidency of William Rainey Harper, who had built the school from Rockefeller money, Edward Bemis, a former Ely student, attracted unwelcome attention in 1894 when he lectured against corporate monopolies of gas and the railroads. "Universities cannot be considered to represent the results of the latest scientific thought in many cases," Bemis wrote to his old teacher Herbert Baxter Adams five years after he was forced to resign, "but rather the views of donors, or the thought of trustees as to what hoped-for donors might desire." As Mary Furner has shown, it was clear that "professional economists were not going to be permitted to make ethical judgments that challenged basic values or threatened entrenched interests." 57

\section{The Historico-Political School and the New University}

The power of the industrialist-funded university in these debates over government regulation, ownership of industry and the rights of labour affected the professional make-up of emerging associations like the AEA. If the AEA was meant to be the American equivalent of the German Verein für

\footnotetext{
${ }^{55}$ Harold E. Bergquist, "The Edward W. Bemis Controversy at the University of Chicago," AAUP Bulletin 58 (1972): 384-393.

${ }^{56}$ Edward Bemis to Adams, 3 December 1900 (box 2), H.B. Adams Papers (MS.4), Special Collections, Milton S. Eisenhower Library, The Johns Hopkins University. (Hereafter H.B. Adams Papers)

${ }^{57}$ Furner, Advocacy and Objectivity, 101; Manicas, "The Social Science Disciplines," 61; Cohen, The Reconstruction of American Liberalism, 165-172.
} 
Sozialpolitik, which they admired while in Germany for the attention it gave the new social questions induced by modern industrial capitalism, it would not be so simple. ${ }^{58}$ With the help of White, C.K. Adams, and Walker, who had become a more vocal supporter of controlled expansion of state functions, along with a number of Christian social reformers, the new AEA created a platform in 1884. It proclaimed, "We regard the state as an education and ethical agency whose positive aid is an indispensable condition of human progress...the doctrine of laissez faire is unsafe in politics and unsound in morals; and it suggests an inadequate explanation of the relations between the state and citizens." 59 Despite the initial zeal of the platform, within three years the original constitution was effectively disemboweled, gutted of any reference to "the conflict between labor and capital" or its original calls for "solutions requir[ing] the united efforts, each in its own sphere, of the church, of the state, and of science." Any allusion to advocacy or activism was removed and "only the first objective, on encouraging economic research, was left standing." Seligman would later insist that the changes were not made "in deference to a coterie," but it was clear that the implicit and explicit endorsement of socialism or any advocacy from an economics chair would not stand. ${ }^{60}$

Professionalizing thus had substantial ideological and discursive effects

\footnotetext{
${ }^{58}$ Bender, A Nation Among Nations, 264-266.

${ }^{59}$ Ibid.; Ross, Origins, 110. Interpretations of what caused this revision have varied. The most influential, however, remains that presented in Furner's Advocacy and Objectivity, 101-105.

${ }^{60}$ Manicas, "The Social Science Disciplines," 60-61.
} 
on the social sciences. It created, paradoxically, a physical and intellectual space where radicalism and conflict among colleagues could be discouraged because the appearance of contending parties with separate biases undermined the apparent neutrality and objectivity of economics. As Ross has argued, "in the heated political context of the Gilded Age, where deviations from conventional exceptionalist norms were painfully visible, the historical economists' overt ethical stance, sympathy with labor, and tendencies towards socialism made their objectivity suspect and endangered the professional project," which was increasingly anchored to the modern, industrial university. ${ }^{61}$

While Newcombe, Godkin, William Graham Sumner and their more devout laissez faire colleagues would continue to provide some of the most colourful attacks on the ethical economists, it should be noted that the same professional project that attacked the ethical economists also drew power away from the older generation of social scientists attacking them. In 1878 the ASSA attempted to merge with the newly minted Johns Hopkins University. But it was White's former colleague, classmate, fellow mugwump Republican, and close friend, Gilman, who scuttled the idea. The then-president of both the ASSA and Hopkins declined the offer from Sanborn, the major mover and secretary of the now waning ASSA, for fear that aligning with the type of social science the ASSA cultivated would interfere with his own efforts at professionalizing, because it placed the historico-political school too close to

\footnotetext{
${ }^{61}$ Ross, Origins, 117.
} 
advocacy on causes in which they had little interest. ${ }^{62}$ In his 1880 presidential address to the ASSA, Gilman affirmed the goals of the association, arguing for more professionalization and specialization in the social sciences by binding their fortunes more firmly to the traditional authority, and to the industrial reform of, the university. He reminded members that "the association is not a society for the promotion of reform, or an assembly whose object is charity; but its object is the promotion of science, the ascertainments of principles and laws" by the same methods as the natural sciences. ${ }^{63}$

Both Gilman and White imagined a social science built on the German model. ${ }^{64}$ For them and the generation of German-trained scholars that came back to America before the ethical economists, the solution did not rest in institutionalized professional associations like Verein für Sozialpolitik, which blurred the line between reform and science and treated the state as an instrument of social policy; rather, for the historico-political school, social science would be most effective, and more likely to proliferate, via the cultivation of the industrial university as an institution for modern specialization. Indeed, Gilman seems to have imagined specialization as the foundation for a professionalization rooted to the new university which would work "hand in glove with both business and government." Gilman knew the

\footnotetext{
${ }^{62}$ Haskell, The Emergence of Professional Social Science, 144-167; Furner, Advocacy and Objectivity, 313-320. Not insignificantly, while F.B. Sanborn was the major advocate of the idea to align the ASSA with the emerging industria university, even after he was rebuffed he was quickly asked by A.D. White to lecture in the first social science courses at Cornell University.

${ }^{63}$ John G. Gunnell, The Descent of Political Theory: The Genealogy of an American Vocation (Chicago: University of Chicago Press, 1993), 45-46.

${ }^{64}$ Gunnell, "The Real Revolution in Political Science," 49.
} 
University of Berlin had an organizational model for the industrializing of natural science, and the new university presidents of the Gilded Age were all aware of the waning influence of the ASSA on legislation. As relatively new presidents, White and Gilman fantasized about the power of a university that would create experts and filter them into the public. "Nothing is so much needed in our country," White wrote to Gilman in 1879, "as departments of this sort to train men for journalism, and for public life. Think not only of the national legislature, but of all the state legislatures, of all the county boards and supervisors and municipalities-bodies in which college-bred men ought to exercise a controlling influence for good, but don't." ${ }^{65}$ Walker, once a Washington circle bulwark, optimistic about the scientific management of the state by an educated meritocracy, understood that the center of professional gravity in the social sciences (as with the natural sciences) was moving towards the university. He accepted the presidency of MIT in 1881, leaving Washington behind. ${ }^{66}$ The new university in America was so successful at assembling the resources, money, and people to industrialize social science that it stripped power away from older social science reformers at the same time that it tempered the new reformers. ${ }^{67}$

The reconstruction of liberalism in Gilded Age political economy is not adequately captured by histories that treat the change as a dialectical clash

\footnotetext{
${ }^{65}$ A.D. White to D.C. Gilman, 12 April 1878 (Box 2.9), Daniel Coit Gilman Papers, Special Collections, Milton S. Eisenhower Library, Johns Hopkins University. (Hereafter refered to as Gilman Papers)

${ }^{66}$ For a very early work that clearly connects these three major university reformers to shared university reforms and professional association formation see, Earle D. Ross, "The Great Triumvirate of Land-Grant Educators: Gilman, White, and Walker," The Journal of Higher Education 32 (1961): 480-488.

${ }^{67}$ Manicas, "The Social Science Disciplines,"53-54.
} 
between generations. Rather, looking at the developing concept of liberal internationalism against the backdrop of the simultaneous professionalization and disciplinary fragmentation of the social sciences in this period it is clear that one of the most impressive achievements of new industrial-university builders like Gilman, White and Walker was their ability to construct professional consensus around a belief in American exceptionalism, continuing the Whig ideal of change tempered by continuity. However, for these early historico-political figures, the insulation of American civic institutions such as the university and legal institutions from European tendencies, meant clinging to an idea of sovereignty and internationalism that placed the sovereign and territorialized nation-state as the key ingredient to spreading liberal values more globally. Put another way, unlike many in the future generation of social internationalists, who would adapt the European idea of social politics filtered through the state to make a case for an active state, the historico-political school imagined social ideals filtered through civil society and directing the formation of the state to prevent its unnecessary expansion.

\section{The Historico-Political School: Disciplines \& Professionalization}

It was not a coincidence that these university reformers were also the lynchpins of the historico-political school that defined the new contours of internationalism in the United States. The list of these social science professonalizers is impressive. Gilman (Yale, California, Hopkins; History), 
White (Cornell; History, Economics, Political Science), Charles K. Adams (Cornell and Wisconsin; Political Science, Economics, History), G. Stanley Hall (Clark; Psychology) and James B. Angell (Vermont, Political Science, International Law), to name only the most prominent university presidents, had each studied in Germany, were all involved in the creation of particular social science disciplines, and all institutionalized the study of the theory and practice of international law and relations in their careers. ${ }^{68}$

Throughout the 1870 s and early 1880 s, this group played dutiful roles in the ASSA. ${ }^{69}$ But as it became increasingly apparent that the ASSA was intent on maintaining a broad, generalist organization, the German-trained university reformers worked with the new generation of university academics to break away. The first break with the ASSA was not the AEA, but the American Historical Association (AHA). Joining with Herbert Baxter Adams, of the younger cohort of German graduates, Gilman suggested that his colleagues form a professional association, "truly national" rather than sectional or statebased as part of a general attempt to shore up the nation-state and heal the wounds of sectionalism that lingered after the Civil War. ${ }^{70}$

The first business meeting of the $A H A$, held a year before its first

\footnotetext{
${ }^{68}$ Robert Vitalis, "Birth of a Discipline," in Imperialism and Internationalism in the Discipline of International Relations, ed. David Long and Brian C. Schmidt (Albany, N.Y.: SUNY Press, 2005), 159182.

${ }^{69}$ For more on the Grover Cleveland-mugwump adherence to the Cobden-Bright school of free trade see Frank Ninkovich, The United States and Imperialism (Malden M.A.: Blackwell, 2001), 12.

${ }^{70}$ For more on the intentions behind the formation of the AHA and the purpose of its nationalistic focus see Peter Novick, That Nobel Dream: The 'Objectivity Question' and the American Historical Profession, (New York: Cambridge University Press, 1988), 21-28. H.B. Adams, "Secretary's Report of the Organization and Proceedings," American Historical Association Conference Papers Saratoga, 9-10 September 1884, HB Adams Papers.
} 
conference in 1884, brought to the surface extant tensions between Germantrained specialists and the generalists of the ASSA. When C.K. Adams joined other members from local and state historical societies calling for a distinct association, the serving ASSA president and Washington Circle man, John Eaton, warned AHA members of a "tendency in this country toward excessive specialization," and argued that the ASSA's structure facilitated the much needed dialogue among constituent interests that would break down with specialized disciplinary communities. One student retorted that his professor in New York had told him he did not intend to join the AHA precisely because he assumed it would be attached to the ASSA, and the debate grew more personal. To calm the situation, White proposed a compromise. The AHA and ASSA should organize annual conferences together but remain distinct bodies, if only because the number of historians would soon exceed that of ASSA members. ${ }^{71}$

In fact, in under a year the AHA exploded to over 220 members, and then to over 400 with White's high-profile presidency in the first year. Even more significant was who had signed on and what the association managed to do with that new membership. With Justin Winsor and C. K. Adams as vice presidents and H.B. Adams as Secretary, the "notable" members read like a roll-call of influential intellectuals, reformers, and future politicians who would dominate turn of the century national politics: C.F. Adams, Henry Adams, John Bigelow, George Bancroft, Charles J. Bonaparte, George W. Cable, George

\footnotetext{
${ }^{71}$ Ibid.
} 
William Curtis, Gilman, Senator G.F. Hoar, Henry Cabot Lodge, Charles Eliot, Francis Parkman, White, and a young Woodrow Wilson, were but a few notable early members. The move to specialize did not necessarily make the AHA more academic. It still contained a substantial number of amateurs, jurists, and political figures, and some have argued that it was not a professional body in the true sense of the word. ${ }^{72}$ But breaking off from the ASSA did allow the AHA's membership to assert professional authority in two areas where its mother-association was failing. First, the AHA drew members from the North and South of the nation. Members made much of the organization's role as a nation-building institution precisely because it aimed to end the era of the "waving of the bloody shirt."73 But, perhaps more importantly, in driving away from the ASSA, the historians carried forward organizational and promotional methods (journals, conferences, seminars, graduate studies, dissertations) they had learned as graduates of Wissenschaftliche objektivität studying in the country of Leopold von Ranke. Ranke, not surprisingly, was nominated an honorary AHA member at the first meeting.

There are roughly three interconnected criteria that scholars consistently identify as integral to creating professional identities. The first is enclosure: the creation of a distinct body of knowledge that commands assent,

\footnotetext{
72 J. Franklin Jameson, "Early Days of the American Historical Association, 1884-1895," The American Historical Review 40 (1934):), 1-9; Novick, That Noble Dream, 54.

${ }^{73}$ Jameson, "Early Days of the American Historical Association," 7.
} 
which one must refer to and build on to be considered an authority. ${ }^{74}$ The second is methodological standardization: the establishment and enforcement of norms and standards of technique that serve as shibboleths, communicating belonging in a particular professional world. Third is the promotion of works, to a targeted audience, that communicate an exclusive control of diagnostic and prescriptive tools that follow the methodological standards of a discipline. This usually means balancing the act of promotion to a general readership with dissemination of esoteric works to colleagues. ${ }^{75}$

As Peter Novick has amply shown, American historians who returned from Germany and interpreted Wissenschaft in the American milieu created their professional discipline by binding on to the already powerful discourses of scientism and realism, creating what H.B. Adams and others would interpret as the science of history. ${ }^{76}$ For those who went to Germany as part of the 1870 s cohort, Ranke was the embodiment of this scientific tradition. They believed (despite largely inventing the tradition themselves) he, along with Barthold Georg Niebuhr (Lieber's mentor), had "perhaps more than all others influenced historical study in the nineteenth century." The AHA helped create an enclosed disciplinary space where this science of history could be asserted, subsuming other bodies of knowledge and locking out any

\footnotetext{
${ }^{74}$ For discussion of enclosure see Andrew Abbott, The System of Professions: An Essay on the Division of Expert Labor, (Chicago: University of Chicago Press, 1988).

${ }^{75}$ Novick identifies these, in slightly different language, as key to professionalizing the social sciences perhaps the most interesting work on this has been done by historians of medicine and science on the monopolization of tools and enclosure. See for example, Roy Porter, The Popularization of Medicine, 1650-1850 (New York: Routledge, 1992).

${ }^{76}$ For a deeper discussion of Ranke and the particular meanings and interpretations of Geistwissenschaften, Novick, That Noble Dream, 26-29.
} 
advocates for reformatory causes that ostensibly undermined the objectivity and scientific disinterest of historians. The $A H A$ also helped streamline methods, creating commissions on education in public schools and serving, as J. Franklin Jameson wrote, not "to evoke originality, to kindle the fires of genius...but to regularize, to criticize, to restrain vagaries, to set a standard of workmanship and compel men to conform to it." ${ }^{\text {"I7 }}$ Lastly, the AHA helped redefine the audience for works. While Novick has cited the AHA as proof that disciplining history was a "becoming somewhat less of an intellectual and somewhat more of an academic enterprise," it brought together a national membership, focusing on standards and methodological norms. ${ }^{78}$

If the AHA was an expression of an emergent national professional project, its vocabulary and methods were furnished by newly established historico-political departments in modernized universities, chaired by the younger generation of German-trained scholars. In 1880, four years before the AHA was established, Gilman backed H. B. Adams's Graduate Program in Historical Studies at Hopkins, and Seth Low, a close colleague of White and Gilman, backed John Burgess-Lieber's replacement-in creating Columbia's School of Political Science. ${ }^{79}$ Adams's work with graduate students at Hopkins was particularly influential for the proliferation of a historico-political school in

\footnotetext{
${ }^{77}$ Herbert Baxter Adams, "History in American Colleges," Education: A Monthly Magazine 6 (1886), 92100 .

${ }^{78}$ Peter Novick, That Noble Dream, 53.

${ }^{79}$ John G. Gunnell, "In Search of the State: Political Science as an Emerging Discipline in the U.S.," in Discourses on Society: the Shaping of the Social Science Disciplines, ed. Peter Wagner, Björn Wittrock, and Richard Whitley (Norwell, MA: Kluwer Publishers, 1991), 153; Manicas, "The Social Science Disciplines," 46.
} 
the US, supplying many of the students that would attend that first business meeting of the AHA. It also cultivated some of the most influential future social science professionalizers: Albion Small (sociology, Chicago); E.A. Ross (sociology, Stanford and Wisconsin); John R. Commons (economics, Syracuse and Wisconsin); Edward Bemis (economics and sociology, Chicago and Kansas); Henry Carter Adams (economics, Cornell and Michigan); Dewey (philosophy and education; Michigan, Chicago, and Columbia); Frederick J. Turner (history, Wisconsin, Harvard); and Wilson himself (history, political economy, jurisprudence; Wesleyan, Bryn Mawr, and Princeton). Burgess established a School of Political Thought at Columbia, which provided the ideological foundation for The Academy of Political Sciences (1880) and the Political Science Quarterly (1886), signaling the start of a disciplinary split between the study of politics and history.

Differences in disciplinary emphasis became more defined in the 1890 s, but for most of the 1880s the departments led by H.B. Adams and Burgess, the $A H A$, and their tight professional connection to the industrial university, made possible the ascendance of a new "scientific history," convinced of its ability to reflect the past realistically and to understand thereby the present political and social world. Adams would often write or tell his students, "History is past Politics and Politics present History," a phrase that appeared frequently in his work and which he proudly posted on his 
seminar room door. ${ }^{80}$

\section{The Historico-Political School and the Internationalism of Teutonism}

With the development of new institutional networks-universities, graduate classes, university chairs and national professional associations-dependent on popular acceptance, it became increasingly important that methodological norms be seen as uncontroversial. Against the backdrop of the labour and social unrest of the Gilded Age, the "scientific history" that Adams and Burgess believed possible was particularly useful in adapting American exceptionalism to conservative ends. Like its Whig forbearer, the historicopolitical school was very much concerned with preserving republican institutions and political principles from the demos and did so, as Ross notes, by "subordinating individual rights to history and the community" in their work. ${ }^{81}$ But, unlike their predecessors, the shifting foundations of authority away from religious rationales towards more secular-scientistic ones meant the historico-political school was careful to avoid explicit "reference to Providential power or America's millennial destiny," such as George Bancroft's standard setting History of the United States of America (1834) had made years earlier. ${ }^{82}$ Put simply, to shift towards a more "realistic" historical account in the Gilded Age, the historico-political school had to strip away any reading of history or politics that would have appeared romantic by their

\footnotetext{
${ }^{80}$ John G. Gunnell, "In Search of the State: Political Science as an Emerging Discipline in the U.S."

${ }^{81}$ Ross, Origins, 73-74.

${ }^{82}$ Ross, "Anglo-American Political Science," 269-273.
} 
contemporary standards.

This is not to say that all the romanticism was stripped from their work. Their teaching and writing still embraced a world-historic lens, or what Ross has called the "prehistoricist cast of mind," which positioned the US at the apex of a larger, Hegelian march of history through the westward movement of Teutonic cultures and institutions. As an ontological imperative in their work, this westward movement of liberty both connected them firmly to Ranke and/or Lieber, and defended the racial and meritocratic elitism of civic institutions that many felt were threatened by a new wave of European immigrants and the broader demos of Gilded Age society and politics. For Adams, whose specialty was local history and government, studying how German-Teutonic institutions had traveled through space and time to land in the local governmental practices of New England municipalities was more than just a research interest. He adapted the Teutonic germ theory as a pedagogical tool to connect his students to a particular ontology of the nation, situating the US and its Teutonic civic institutions at the vanguard of liberty for the world. ${ }^{83}$ It was important, he argued in Methods of Historical Study, to teach students how to connect their community "not only with the origin and growth of the State and Nation, but with the mothercountry [sic], with the German Fatherland, with villages and communities throughout the Aryan world." 84 For Adams, history revealed the significance of Teutonic institutions by

\footnotetext{
${ }^{83}$ Farr, "The Historical Science(s) of Politics".

${ }^{84}$ Herbert B. Adams, Methods of Historical Study, The Johns Hopkins University Studies in History and Political Science (Baltimore: Freeman Press, 1884), 21-23.
} 
uncovering how they had kept the act of governing rooted to civic institutions rather than to interests of the sovereign state.

Burgess also saw his work as scientific and world-historic in scope, drawing from "the method, which has been found so productive in the domain of natural sciences," and applying it to "political science and jurisprudence." 85 But exactly how natural science methods could translate into the world-historical teleology that seemed the a priori foundation of the new history was not clear. Like Adams, Burgess "blurred historical change by overlaying past and present," arriving at the foregone conclusion of political and state supremacy of Teutonic cultures like the British, Germans, and Americans. But where Adams emphasized history, Burgess emphasized how the present proved that Teutonic institutions were indebted to the past (although they further refined liberal democracy through constitutionalism) ${ }^{86}$ The "three great peoples" of Germany, England, and the US, he proposed, "have planted all of their institutions upon the basis of the national state and are developing them through the realization of the national principle." As John Gunnel put it, "No one propagated the Teutonic theory of state and the Hegelian image of history as long and as assiduously as Burgess, and no one did more to make the state the object of political science." 87

But in developing a historico-political method that treated the march of

\footnotetext{
${ }^{85}$ John William Burgess, Political Science and Comparative Constitutional Law, Volume One (Boston: Ginn \& Company, 1890), 1.

${ }^{86}$ Ross, "Anglo-American Political Science," 24.

${ }^{87}$ John G. Gunnell, "In Search of the State," 143.
} 
Teutonism across Europe, into Britain and culminating in the US as a fundemental objective law, Burgess actually propagated a particular ontology of the nation-state to the level of universal liberal state form. The implications of this ontological universalism were significant for the production and reproduction of a particular kind of internationalism built around American exceptionalism. With it, Teutonists of the historico-political school were able to feed the American exceptionalist idea that their nation had achieved a uniquely stateless state form, while simultaneously turning the American state into a normative social scientific standard against which all other societies' development was to be measured. A portion of Burgess' introduction to his Political Science and Constitutional Law exemplifies this double move especially well:

I would say that the book represents the Teutonic nationsthe English, French, Lombards, Scandinavians, Germans and North Americans - as the great modem nation builders, that it represents the national State, that is, the self-conscious democracy, as the ultimate unit of political history; that it justifies the temporary imposition of Teutonic order on unorganized, disorganized, or savage people for the sake of their own civilization and their incorporation in the world society; that it, therefore justifies the colonial system of the British Empire especially; that it favors federal government, and finally, that it extols above everything the system of individual immunity against governmental power formulated in the Constitution of the United States and upheld and protected by the independent judiciary. ${ }^{88}$

American democracy, in Burgess's formulation, had developed out of the germ of liberty carried by Teutonic nations, but was perfected in the

\footnotetext{
${ }^{88}$ Burgess, Political Science and Comparative Constitutional Law, 1: 2.
} 
American separation of government and the peculiarly diffused power of the state. "With us, government is not the sovereign organization of the state," Burgess argued. "We have the distinction [between state and government] already in objective reality...This is the point in which the public law of the United States has reached a far higher development than that of any state in Europe." ${ }^{89}$ Burgess reinforced this exceptionalism by holding up the federalnation-state, which separated government from the sovereign organization of the state, as the apex of a progressive evolution of the state per se. But by placing this form on a world-historic scale, and proposing that it was arrived at with scientific precision, Burgess effectively rationalized the child of the Teutonic nation-state as the core of a liberal international order.

For Burgess, the core of this international order was an "ethnical affinity" for liberty, carried at a biological level by the Teutonic character and embodied at the institutional level by shared civil practices such as constitutionalism, legalism, republicanism and the liberal subject. The "blood [that] courses through the veins of the majority of Germans, Englishmen, Scotchmen and North Americans," Burgess argued, "produced and maintains a substantial consensus of opinion concerning rights and wrongs, liberty and government, policy and interests." ${ }^{\prime 90}$ The connection between nations was, then, an "ethical as well as an ethnical bond," where smaller Teutonic nations like the Swiss and Scandinavians worked unconsciously with their larger

\footnotetext{
${ }^{89}$ Ibid., $57,63$.

${ }^{90}$ John W. Burgess, "Germany, Great Britain and the United States," Political Science Quarterly 19 (1904), $2-3$.
} 
national counterparts to "spread Teutonic culture," and liberalInternationalism was, on the one hand, international law,

requir[ing] each state to know the constitution of the state with which it treats; and this rule frees each state at its option from any international obligation which its government seeks to saddle upon it through the exercise of a power not granted to its government by its constitution. ${ }^{91}$

Echoing Lieber and those who opposed codification in the 1870s, Burgess proposed that the law of nations depended on a deeper ethical impulse that emanated not from the state per se, but from a nation of people who had the right to create their own laws under their own constitution. But Burgess further specified that such constitutional nation-states already shared an international ethos because they drew upon the same Teutonic cultural institutions that could govern without recourse to the autocratic state. Far from seeing the world as culminating in a codified or socially connected single state, the selfconscious, territorially bound nation-state was the only legitimate unit in internationalism. "I do not ignore the fact that some great publicists think they see in the body of general agreements, positive and customary, between states, called international law, the postulates of a consciousness wider than that of a single state," Burgess noted. But, he objected, "at the present stage of the world's civilization, a nearer approximation of truth seems to be attainable from the standpoint of a national state consciousness than the standpoint of

\footnotetext{
${ }^{91}$ John W. Burgess, "Federal Government and International Responsibility," Political Science Quarterly 6 (1891), 343.
} 
what is termed the consciousness of mankind."92 This reading of internationalism undermined arguments for a world state, positing that the existing law between Teutonic nations was the highest international consciousness possible under the conditions of "common consciousness".

While the romanticism of previous generations of historians and international legalists had been buried under more scientific language, the historico-political school's belief in the reality of Teutonism was still very much a romantic narrative of history. Northrop Frye has argued that romantic narrative always carries a revolutionary potential in its presentation of an ideal world. But, when presented "under a guise of realism" that invites the reader to identify with the society being portrayed, romance results in conservatism. $^{93}$ The very formation of the modern research university, national professional association, and historical methods that emphasized the centrality of the nation, were all embodiments of a romantic desire for knowledge that better aligned the socio-political with an underpinning human nature. This romanticism was justified and legitimated by sweeping scientific works of historical and political narrative, but all treated the American nationstate as the touchstone of socio-political and economic development and objectivized liberal nation-states as the most realistic units of social and political solidarity. The internationalism of the historico-political school was therefore no less ethically motivated than that of Ward. But in treating the

\footnotetext{
${ }^{92}$ Burgess, Political Science and Comparative Constitutional Law, 54.

${ }^{93}$ Cited in Ross, "Grand Narrative," 655.
} 
moral impulse behind American nation building as both realistic and universal in order to feed American exceptionalism, the ethos of historicopolitical internationalism was fundamentally conservative. Growing out of the Whig emphasis on change tempered by institutional continuity, internationalism was no longer compelled by the Kantian ethics of what ought to be. Instead, internationalism was seen as an expression of the ethical order as it was, determined by historical and economic laws that proved all change was necessarily tempered by the existing institutional and social mores and had to be preserved against unsettling revolutionary forces.

\section{New Economics: From Historico-Political to Social Liberal Internationalism and Back Again}

The economists that founded the AFA also built on this gradualist reading of the development of nation-states and internationalism. Like the AHA, the AEA must be understood as part of a local power struggle over professionalism and expertise, affixing itself to new disciplinary discourses, the institutional authority of the university and, again, to the romantic project of nationbuilding. While much has been made of the tempering effect that institutions like the university had on the socialism and labour unionism of these new economists, the internationalism of Seligman, Clark, Ely, and H.C. Adams reveals a conservative realism substantially shaped by their own search for professional authority. On the one hand, their romanticism about the possibility of a more ethical society guided by a leveling state led these thinkers to try to expand the base of governmental authority to include 
institutions such as unions and the church (institutions the older guard had denied recognition as articulators of liberty). This exposed the economists to persecution from those who saw labour, egalitarian religious movements, and a social state as illiberal because they threatened to bypass the authority of pre-established civic institutions manned by the Gilded Age gentry class. But, despite differences over the precise fountainheads of the ethical impulse and the institutions that would aide in social control, the historicism of these young economists meshed well with the historico-political school, which quickly recognized their similarities and worked with the economists to develop new positions in the increasingly industrially influenced university.

Unlike the first generation of German-trained scholars influenced by Ranke and Lieber, the young radical economists were in Germany at a time when socialism seemed to threaten established social orders in all industrial societies, demanding state action, in concert with other institutions. But as Ross has noted, except for Seligman, the young economists were from evangelical New England families that valued moral conscience in social, political and personal life and, unlike their gentry class predecessors, "felt no real conflict between science and religion." ${ }^{\prime 94}$ With this moral impulse, the new economists imagined a more ethical state working to achieve equality and a common good, supporting the working class and fighting against the concentration of wealth in the hands of increasingly few. This led Ely, Adams, and Clark to find inspiration in the social problems that plagued liberalism

\footnotetext{
${ }^{94}$ Ross, Origins, 102-103.
} 
and to imagine new institutional collections influencing policy and society.

Yet nor were they radical statists and, as historicists, they understood socialism to be defined by the particular nation in which it developed. As Ely proposed in an 1887 piece on American socialism, "the practical character of the American" defined its interaction with socialist ideas so that "ten years ago English-speaking laborers were considered too practical to listen to dreamers and heralds of coming Utopias," their common sense an "allsufficient shield against the speculations of continental philosophers and the allurements of French and German agitators." ${ }^{95}$ But with the publication of Henry George's Poverty and Progress and the economic collapse of 1873, Ely argued that a modern socialism took hold of the American practical mind, finding expression in the discontent of labourers. Still, Ely was emphatic, it was important not to confuse American socialism with groups such as The Internationalists, which he considered "a party of violence." He preferred the Socialistic Labor Party, which held out "hope of a peaceable revolution of society" and was composed of more "highly educated and refined men."96 "The fairest-minded person," Ely argued of The Internationalists' attack on the church and family,

cannot blame a writer for holding up to condemnation any concrete, actually existing party which wages war against all that we consider most sacred, and which seems to abolish those institutions which we hold to be of inestimable value,

\footnotetext{
${ }^{95}$ Richard T. Ely, Recent American Socialism, ed. Herbert Baxter Adams, Studies in Historical and Political Science (Baltimore: Johns Hopkins University, 1888), 1, 18.

${ }^{96}$ Ibid., 21.
} 
both to the individual and to society. ${ }^{97}$

Ely had little patience, therefore, for radicals who attacked the very institutions of cooperative organization that he thought could work towards "economic as well as political" democracy and universal cooperation. Through this lens, he interpreted the Commune as an "insurrection" of communalists that were chasing an unmodern solution to modern problems. An anarchic organization of communes as a "confederation" was "not communist," but rather "communalist" because of its parochial antimodernism. Ely believed that "modern forms of communism or socialism" should be "cosmopolitan and practical in character." modern - so practical in its political development, but cosmopolitan in its hope for a better world -it had the unique capacity to provide an "escape for present and future social dangers." 99

To escape fully, Ely felt that "Science the State and the Church" had to be accepted as "the chief agencies through which we must work for the amelioration of the laboring class, as well as of all classes of society." Rather than stigmatizing these agencies, or naively hoping to progress beyond them, he imagined them working toward social order and coordinating its "harmonious action." Of course, the realization of this harmony to "remedy against the evils of socialism, nihilism, and anarchism" required "a better education in political, social and economic science." The AEA and Ely were,

\footnotetext{
${ }^{97}$ Ibid., 32.

${ }^{98}$ Richard T. Ely, French and German socialism in modern times (New York: Harper, 1883), 16, 3.

${ }^{99}$ Ely, Recent American Socialism, 73.
} 
by this formula, guards against both the radicalism of violent and atavistic socialism, and the parochialism of outdated laissez-faire thinking, both of which tended toward extremes instead of moderate reform. The nature of American socialism for Ely was reform-minded, moderate, and gradualist, guided by a new scientific aristocracy holding "the light of true science."100

For the ethical economists, a more equal society created the conditions for a truly social international. As E.R.A. Seligman would argue at the turn of the century, "Economic equality among individuals creates...democratic virtues," while "economic equality among nations can alone prepare the way for international peace and justice." ${ }^{101}$ Ely understood this when, over two decades earlier, he argued that international postal unions, congresses, courts of arbitration, and efforts at industrial legislation were signs of a "continued growth of international relations" leading ever closer to the formation of "a world-organization, guaranteeing to the nations of the earth perpetual peace." His hope that free trade would "knit nation to nation so firmly" subsequently evaporated, as he realized it had only united "a few great merchants and manufacturers, and led to cosmopolitan feeling among the wealthier classes." ${ }^{102}$ But his hope of an international order linked through ethical social bonds, rather than coldly capitalistic ones, was taking hold among American social scientists.

\footnotetext{
${ }^{100}$ Ibid., 72, 74. For his later statements calling for a scientific aristocracy see Richard T. Ely, An American Aristocracy (box 8, folder 5), Richard Theodore Ely Papers, State Historical Society of Wisconsin. (herafter referred to as Ely Papers)

${ }^{101}$ Edwin R. A. Seligman, "The Economic Interpretation of History. III," Political Science Quarterly 17 (1902), 286.

${ }^{102}$ Ely, French and German Socialism, 187-188.
} 
While Ely attacked free trade, his idea of a modern socialism and hope for a system beyond the nation-state prevented him from accepting the protectionism and statism Bellamy proposed in Looking Backward. ${ }^{103}$ Ely shared his economist colleagues' view that old style protectionism and tariffs were steps back in the direction from which society had already progressed. As Walker argued in his assessment of socialism in 1887,

The peculiarity of the new movement is that it is to owe its initiative and its main impulse to the laboring class. What strikes me as most important, with regard to the future, is the consideration that, while protectionism is to become dogma and a fighting demand of the out-and-out socialists everywhere, it would be in a consummated system of protection that the rampant, aggressive, and destructive socialism, which is such an object of terror to many minds, would find an insurmountable barrier. Socialism can never be all we dread unless it becomes international; but the consummation of protectionism is the destruction of internationalism. ${ }^{104}$

Ely tried intermittently to rescue the concept of socialism in America from being equated with such inflexible protectionism and tariffs, and he and his colleagues used a Whiggish history of economic thought to explain why modern socialism was actually an extension of the national liberalism that had been handed on from the English. The church, Seligman offered, was the first international in history, and it had communicated awareness of solidarity beyond the nation through history, first into the mercantile system and English authors of free trade. They created a sense of contained "national economy"

\footnotetext{
${ }^{103}$ Richard T. Ely, Problems of Today: A Discussion of Protective Tariffs, Taxation, and Monopolies (New York: T. Y. Crowell, 1888).

${ }^{104}$ Walker, "Socialism," 107-108.
} 
along with notions such as the balance of power and the desire for increased population, although these were challenged by the physiocrats of France, who "represented the universal, the cosmopolitan, the international view." Seligman insisted that the physiocrats' treatment of the laissez faire individual operating without sovereign government was the spirit but not the structure handed down to Smith, Ricardo and Malthus. They would effectively meld the physiocratic and mercantile into liberal Free Trade. ${ }^{105}$ H.C. Adams echoed this reading of free trade as the first significant internationalism in his own teachings, arguing that "the early [mercantile] society did not admit industrial competition; the early years of modern society admitted only international competition; in modern society we realize both international competition and competition between persons." 106

Adams proposed that the real question revolved around "the wisdom of making the political and the industrial boundaries of a people coincide." The "free traders deny the wisdom of such legislation" because they claim it "deprives the people of one country from the enjoyment of the advantages of production ... possessed by another country," and because "it obstructs the benefits of hereditary skill or national peculiarities which give one people an advantage over another." But, Adams concluded, when faced with the fact that "legitimately fair trade does not tend to unite peoples of various countries," it

\footnotetext{
105 E.R.A. Seligman, et al., "Continuity of Economic Thought," Science Economic Discussion, (New York: The Science Company, 1886), 8-9.

${ }^{106}$ Henry Carter Adams, Outline of Lectures Upon Political Economy: Prepared for the Use of Students at the University of Michigan and Cornell University (Ann Arbor: Register Publishing House, 1886).
} 
became apparent that the best hope for international cooperation rested in "the advocacy of reciprocity on the basis of international treaty rather than either Free Trade or Protection." 107 Seligman called this "polishing the edge of diamonds handed on from these Anglo theorists," to fit the industrial reality of his time. ${ }^{108}$ In trying to salvage their collectivist goals and establish a progressive, more socially inclusive and ethical internationalism, the ethical economists quickly retreated to the shibboleth of solidarity provided by Anglo-Saxonism, with its accompanying ideals of liberty and juridical sovereignty.

It is difficult to overstate the impact debates over the historical versus deductive teaching of economics had on the conceptual formation of internationalism among the ethical economists. Throughout the 1880s, Seligman, Ely, Patten, and Adams increasingly fell back on the exceptionalist narrative of America as the historical inheritor of liberty in order to support their case for economics as a historical method, and to emphasize the connection between particular economies and political regimes. Invariably, criticisms emerged, such as from Harvard's Charles Dunbar, that the historical approach was not the revolution that Ely and others had proclaimed.

These critiques played to the ASSA-Brahmin distrust of German historicism that defined political economy a decade earlier, and the historical

\footnotetext{
${ }^{107}$ Ibid.

${ }^{108}$ Seligman, Science Economic Discussion, 12.
} 
emphasis of the ethical-economists' work changed. ${ }^{109}$ Aiming to de-emphasize their German training and methodological connection to German historicism, they afixed their concept of the rise of internationalism less on the ideal that Teutonic culture vis-à-vis particular civic institutions had communicated liberal and republican traits, and increasingly on a progressive narrative that positioned economic thought as itself the vessel that had passed the mantle of liberty from the British to America. This shift in emphasis in the historical narrative was fundamentally a move away from the Teutonism that had structured much of the conception of internationalism in the Reconstruction and early Gilded ages, and a move towards a newly abstracted idea of AngloSaxonism. This shift could easily have driven a wedge between the old guard of historico-political scientists and the new guard of ethical-economists over the question of what nations were best positioned to lead a still emergent international order. But many of the old guard actually adapted, if only to protect, alongside the now reformed ethical-economists, the functional relationship between social science and jurisprudence that Dunbar and others seemed intent on denying by questioning history's ability to teach lessons and aid in understanding contemporary society with scientific certainty. ${ }^{110}$

Throughout the 1890s, historical narratives explaining the spread of Anglo-Saxon liberty became increasingly popular among social scientists and

\footnotetext{
${ }^{109}$ Charles F. Dunbar, "The Academic Study of Political Economy," The Quarterly Journal of Economics 5 (1891): $397-416$.

${ }^{110}$ For more on this in the economists realm see, Adams in Ely et al., Science Economic Discussion. For an example of the Historico-Political school's defense of this relationship see John W. Burgess, "Political Science and History," The American Historical Review 2 (1897), 407-408.
} 
the wider public . Popularized by the historical works of immensely popular writers such as John Fiske, James Hosmer and Theodore Roosevelt, AngloSaxonism must be understood as an ethno-political framework that was both a response to and attempt to explain away the anxiety brought on by increased immigration from southern and Eastern Europe, which became first noticeable in the late 1880 s and would constitute a majority of immigration by 1896. ${ }^{111}$

Early in that decade, scholars such as Charles McLean Andrews, Edward Channing, Herbert Levi Osgood, and Frederick Jackson Turner had raised serious objections to the Teutonic-origins theory. Andrews questioned whether the self-governing village community of medieval Germany had been reproduced in seventeenth-century New England, and Channing doubted that the self-governing Teutonic village community had ever even existed or that it was possible to draw an evolutionary chain from simple similarities in institutional structures. Though Teutonism dominated the historico-political school in the 1880s, it was not difficult for the likes of Albert Bushnell Hart, John W. Burgess, and H.B. Adams to accept as central an emphasis they had largely already made, by treating the English and Americans as the highest social and political expression of liberty. ${ }^{112}$

\footnotetext{
${ }^{111}$ Anderson, Race and rapprochement, 55.

${ }^{112}$ Novick, That Noble Dream, 87-88; Bluford Adams, "World Conquerors or a Dying People? Racial Theory, Regional Anxiety, and the Brahmin Anglo-Saxonists," The Journal of the Gilded Age and Progressive Era 8 (2009), 200-203.
} 


\section{Venezuela: The Historical Expert in Arbitration and Internationalism}

By the time the Venezuela dispute precipitated the creation of the boundary commission, these currents of Anglo-Saxonism, racial anxiety, and disciplinary fragmentation, along with debates over the capacity of the social sciences to direct government, came to a head. The expert group called together to settle the Venezuela dispute may outwardly have appeared to be little more than an informal gathering of advisors to help the State Department during a diplomatic crisis. It is my contention, however, that the commission provides evidence of the rupture between the old internationalism and the emerging rationalization of the American state and internationalism by social scientific knowledge, the latter taken as more fundamental and universally scientific than legalistic or diplomatic modes of understanding the world. Calling together a commission of experts to report to an international arbitration committee might have seemed to prove the efficacy of the civicinternationalists' world of jurisdictionally sovereign nation-states with shared civil-legal practices. But this old logic was by then subverted by the more scientific facts provided by increasingly powerful disciplinary historians and geographers.

For White and Gilman, Venezuela was a victory on multiple fronts. First, it proved their vision of college men at all levels of government. As Gilman would argue years later, "this story show[ed] how useful the libraries and professorships of this country have been in a crisis that came very near 
involving three countries in war."113 More generally, it also showed the valuable role of the social sciences in guiding and building civic institutions that would foment a liberal international order. ${ }^{114}$ Gilman was not alone in explicitly connecting geopolitical gains with the rise of a powerful new regime of nationalist knowledge that could actually steer internationalism. White was similarly optimistic at the time of the commission, telling one colleague that he believed the work of the commission's experts and the decision to use arbitration would "restore better feeling between this country and Great Britain, as well as between Great Britain and Venezuela. In fact...I feel absolutely sure that this will be its result." Falling back onto the same Anglo-Saxon conception of liberty as the core of international order that H.C. Adams had rehearsed in the economics debates, White proclaimed:

I believe that we are to see arbitration as a great principle, evolved out of these recent differences of opinion between the two greatest countries in the world, and that other reforms and improvements are steadily going on. ${ }^{115}$

Burr shared the sense of accomplishment, and felt it would be highly unlikely that "any civilized state will so soon again be willing to risk derision and posterity by refusing all peaceful arbitration until it has at least set its own scholars at one earnest effort to test the justice of its cause."116 Like Gilman, Burr attributed the success of Venezuela to the rising principle of arbitration,

\footnotetext{
113 Richard Heyman, "Libraries as armouries: Daniel Coit Gilman, geography, and the uses of a university," Environment and Planning D: Society and Space 19 (2001): 295-316.

114 Ibid.

115 A.D. White to Henry Sage, 21 February 1896 (box 74), White Papers.

116 Burr, "The Search for the Venezuela-Guiana Boundary," 407.
} 
and saw the commission as proof that successful arbitration, Anglo-Saxon unity and international peace, depended on the disinterested work of disciplined scholars.

The disciplinary moorings of those scholars that White, Gilman and America's foreign policy apparatus saw as best equipped to gather "the facts" that would guide the commission and arbitration tribunal is revealing. The historian Richard Heyman has argued the commission "relied largely on Dr. Gilman's familiarity with cartography, his knowledge of the reliability of the different map makers, as well as of the physical geography of the territory in dispute." 117 But, in fact, the commission would almost immediately report after looking these maps over that if their "examination has established anything, it is that the maps of the past are not to be relied upon as giving true boundaries. They have been drawn, for the most part, with an imperfect knowledge of the country, and with the still more imperfect knowledge of those historical facts and legal principles which must decide the question."118 White had been clear: history, working out of the legal precedents of prior international treaties, would guide the establishment of a geographical boundary, because these were "historical questions."

The 1890s in America marked the apogee of what I have so far outlined as civic-internationalism. This was a period when it seemed possible that the Lieberesque ontology of the nation-state could provide the basis for an

\footnotetext{
${ }^{117}$ Cited in Richard Heyman, "Libraries as Armouries," 25.

${ }^{118}$ Daniel Coit Gilman and Andrew Dickson White, "Report on the Cartographical Evidence of the Geographers" (box 74), White Papers.
} 
expansive and civilizing world peace, confirming that the exceptionalism and supremacy of the essentially stateless American state form. The nation-state was an expression of a national consciousness, and the latter could ostensibly be discovered through historical examination, using methods that had helped to define German nationalism over the first third of the nineteenth century. But the articulation of that national consciousness in late nineteenth century America depended on a host of civic institutions directed with the precision only social science could promise. "Political Science," Burgess told a meeting of the AHA in 1896, is "the science of the national country state, and is tending to become the science of the human world state."119 Refracted through the Whig desire for strong civic institutions that allowed an elite to mediate between the state and society, the developing historico-political disciplines, especially as they were affixed to already-powerful civic institutions like the university, became themselves proof that a society could progress towards an international without abandoning the shared cultural characteristics many felt essentially and exceptionally American.

Despite the distant promise of a liberal international, in placing civic legal institutions at the core of the ontological formation of the nation and the international, the historico-political school found a way to rationalize the reproduction of local state structures on a world scale. In attributing such a central role to what were already widely characterized as Teutonic or AngloSaxon institutions, they bound onto and helped feed Anglo-Saxon sentiment.

119 Burgess, "Political Science and History," 404. 
Scholars clamored to weigh in on the Venezuela dispute, to proclaim their support for arbitration over conflict. Sidney Sheerwood, a professor of economics at Johns Hopkins, endorsed the idea of racial solidarity vis-à-vis an Anglo-Saxon alliance recently proposed by Arthur Balfour and Joseph Chamberlain, who surmised that such a union cemented through arbitration would guarantee world peace by overshadowing rival alliance systems in Europe. G.B. Adams added his voice to those urging a prompt settlement of the Venezuelan question on racial grounds. He was ready to see the British occupy all the land in dispute if that were necessary to avoid an inter-racial civil war between the two English-speaking nations. Such a war would almost certainly result in the collapse of Anglo-Saxon civilization, he said, and the "ruin of the empire of the world which now belongs to our race" by rival races like the Germans and Russians. ${ }^{120}$

This new goodwill towards an internationalism built on racial solidarity and shored up by the civilized mechanism of arbitration was so intoxicating that when White and other academics attended the Hague Peace Conference in 1899, they boasted of their importance as disinterested arbiters in the emerging international system. Working alongside fellow delegates such as Seth Low and Alfred Thayer Mahan White, the Americans found themselves in a position to define the rational foundations for international relations. White would later recall and transcribe his impatience with the reservations of a German delegate, who was deeply distrustful of arguments for compulsory

\footnotetext{
${ }^{120}$ Anderson, Race and Rapprochement, 114.
} 
arbitration. According to White, the diplomat said that "Modern nations are taking an entirely false route in preventing the settlement of their difficulties by trained diplomatists, and intrusting [sic] them to arbitration by men inexperienced in international matters, who really can not be unprejudiced or uninfluenced." White bemoaned the delegate's "contempt for the plan for creating a bureau," composed of what they derided as little more than "university professors and the like entrusted to carry the machine of the tribunal." ${ }^{121}$ He retorted:

...by opposing arbitration, you not only put a club into the hands of socialists, anarchists, and all the other anti-social forces, but you also alienate the substantial middle-class and the great body of religious people in all nations. You have no conception of the depth of feeling on this subject which exists in my country, to say nothing of others; and if Germany stands in the way, the distrust of her which the Americans have felt, and which as minister and Ambassador at Berlin I have labored so hard to dispel, will be infinitely increased.

Arbitration did not "derogate the role of the sovereign," he assured the German representative. By submitting menial questions such as tariffs, colonial holdings and trade measures to arbitration, White proposed that these reviled "university professors" would relieve "the sovereign and his government... of the parliamentary chicanery based, not upon knowledge, but upon party tactics or personal grudges or inherited prejudices." 122 Arbitration was the core of a liberal internationalism wherein a network of civilized,

\footnotetext{
${ }^{121}$ White, Autobiography of Andrew Dickson White V. 2, 302.

${ }^{122}$ Ibid., 302-305.
} 
sovereign nation-states ameliorated the tensions of trade, colonialism and potentially even national rivalry through universal, objective knowledge. Such knowledge, White argued in a speech at the inauguration of a memorial to Hugo Grotius during the conference, would guard the "treasures of civilization" from the "international hatred which takes shape in monstrous fallacies and morbid fictions regarding alleged antagonistic interests." The delegates for an international arbitration system, he went on to proclaim, held "a mandate from Humanity." 123

But the historico-political school's faith in non-state civic institutions remained anchored to the old civic-internationalist vision of the nation state, which spoke for a very narrow constituency. Placing this new conception of the social sciences at the core of American internationalism may have removed much of its overt romanticism, but the realist insistence on the centrality of the nation-state and a dogged faith in America's exceptional civic-democratic structures meant that a fundamental shift was underway in thinking about the sanctity of sovereignty and the right to participate in international law.

\section{From Civic Internationalism to Social Internationalism in the Age of Imperialism}

By the time of the Venezuela dispute it was apparent that the historicism that

\footnotetext{
${ }^{123}$ Andrew D. White, "Address on the Occasion of the Grotius Commemoration, July 4, 1899," in ed. Arthur Eyffinger, The 1899 Hague Peace Conference: "The Parliament of Man, the Federation of the World" (Martinus Nijhoff Publishers, 1999), 329.
} 
had bound the historico-political and the ethical economists together was fracturing. While a historicist view of economics and politics paved the way for a new view of social science directing government, it also nurtured a certain hubris on the part of the social sciences about their capacity to find deep social principles that cut across locales, explain international society, and direct its management. During the Venezuela crisis, Burgess questioned the validity of intervention between two disputing nations on diplomatic principles alone. Speaking to what he called the "pseudo-Monroism" of the day, he said that "interference must be based on a much wider principle." There was "undoubtedly a duty resting upon civilized states to carry civilization into the abodes of barbarism, and this duty gives a right," but that right "must be limited by the purpose; and must not be made a means for any other end than the spread of civilization." Facing the potential of war with Britain, Burgess argued that the general principle of civilization was much like the rights of property ownership: one could not "justify the expulsion of one civilized power by another from a field properly occupied and fairly well worked. And it cannot justify a civilized power, which itself does nothing for the civilization of a barbaric region, in attempting to hold that region indefinitely against the entrance of other civilized powers." ${ }^{124}$ Territorial sovereignty, it was clear, was a privilege of "Christian nations" with a developed Teutonic or Anglo-Saxon sense of liberty.

\footnotetext{
${ }^{124}$ John W. Burgess, "The Recent Pseudo-Monroeism," Political Science Quarterly 11, no. 1 (March 1, 1896), 51, 53.
} 
But as the agitation for arbitration grew, the ambiguities of a concept of sovereignty applied to a sliding historical scale of development started to create cracks in the historico-political prescription for world peace. Writing for the Baltimore News, H.B. Adams argued:

There has been considerable discussion of the expediency of an international tribunal or permanent court of arbitration. The proposal was made in this country in 1866 that such a tribunal should be instituted, and that it should be composed of distinguished publicists and jurists, whose professional honor and scientific reputation would keep them above all mercenary or partisan considerations, but it is doubtful whether the world is ripe for a permanent tribunal of international arbitration. The power conferred would be so imperial in character that the various governments of the world would hesitate to acknowledge such supremacy...the example set by England and the United States in the Geneva court is the best the world has seen." 125

Whatever vessel carried the capacity for liberal self-government, be it Christianity, Teutonism or Anglo-Saxonism, sovereignty was a product of these deep social forces that a court could not simply bestow. There was, therefore, no purpose in trying to establish a permanent court as part of a world state that would compromise the jurisdiction and sovereignty of the US, simply to achieve the sort of international cooperation already reached by the civilized nations.

If there was any question about the fracturing of civic internationalism. as it had been contained by the historico-political school and embodied by the arbitration movement, the Spanish-Cuban-American and Philippine-

\footnotetext{
${ }^{125}$ H.B. Adams, "Untitled," Baltimore News, 2 March 1896 (series 5, box 48) H.B. Adams Papers.
} 
American Wars put those to rest. Against the backdrop of Frederick Jackson Turner's diagnosis of a closed American frontier and a growing sense among many key policy and commercial interests that expansion into overseas markets was needed to relieve "industrial overproduction and a structural surplus," the historico-political consensus that had made civic internationalism synonymous with liberal internationalism fragmented under the pressure generated by its own rationalism. ${ }^{126}$

The effects of this fragmentation on social science and internationalism were twofold. First, it ended the old historico-political school's effective monopoly in rationalizing liberal internationalism for most middle-class, white Americans. As Bender and Rodgers have noted in their studies of international progressive reform movements, by the turn of the century, easier transcontinental travel and communications facilitated an international consciousness among "social liberals" who shared "social science findings and identified model policies of the emerging social liberalism." ${ }^{\prime 27}$ Where 30 years prior, the extent of self-identified international organs was almost entirely limited to the church, scientific societies and labour unions, by the 1890s a powerful new cadre of reformers was explicitly connecting social reform to the cultivation of an international social consciousness and the establishment of institutions that bypassed traditional channels of state-

\footnotetext{
${ }^{126}$ Thomas McCormick, "From Old Empire to New," 125; Matthew Frye Jacobson, Barbarian Virtues:The United States Encounters Foreign Peoples at Home and Abroad, 1876-1917, (New York: Hill and Wang, 2001), ; Lafeber, The New Empire, 23-30.

${ }^{127}$ Bender, A Nation Among Nations, 281.
} 
political power. This shift challenged the legitimacy of the still fledgling arbitration movement, calling into question its ability to speak for the broad interests of humanity. In so doing, it forced the historico-political school to ontologically retreat deeper into what Ross has called "realistic historicism." 128 This ontological move in turn affected the rationalization of internationalism among American social scientists and policy elites, necessitating its reconstruction according to social, historical and economic forces beneath those formal political institutions that had once served as the measures of civilized society and the rites of passage into the international community.

\section{The Anti-Imperialists}

If the Venezuela crisis was the apogee of civic internationalism, the imperial wars from 1898 to 1902 represented its near total collapse. Venezuela and the arbitration movement brought the various conservative internationalists together by highlighting the importance and promise of nurturing an internationalism that relied on civic institutions rather than the state to build international goodwill. Though the newly-elected President McKinley assured Americans that "no imperial designs lurk in the American mind" because "they are alien to American sentiment, thought, and purpose," the invasion of the Spanish colonies at Cuba, Puerto Rico, the Philippines, and the later annexation of Hawaii, signaled the opposite to the old guard of political

\footnotetext{
${ }^{128}$ Dorothy Ross, Origins, 277-279.
} 
economists. ${ }^{129}$ Those as seemingly diametrically opposed as William Graham Sumner and Charles Francis Adams were drawn together while pro-war annexationist Henry Cabot Lodge derided "the theory of the Manchester school, which maintains that territorial expansion must be stopped because they were likely to interfere with complete freedom of trade." While their actual adherence to Manchester political economy varied, most had carried forward the Whig faith in an aristocracy of the educated, and shared the Gilded Age historico-political belief in a territorially defined and racially homogenous nation-state as the proper expression of popular sovereignty. Though Gilman was not a member of the Anti-Imperialist League, his 1898 biography of James Monroe romanticized the former State Secretary's consistent belief that "America is for Americans," resisting the pull of British sovereignty. ${ }^{130}$

Burgess shared the hope that avoiding colonialism would help preserve the exceptional nature of liberty he believed was ensconced in the Constitution. Heeding the criticism of those who argued there were social principles deeper than those of particular institutions and constitutions, Franklin Giddings, the second chair of sociology in America at Columbia in 1894, countered that while "man is more than constitutions ... man is not much without constitutions and institutions." As a constitutionalist, Burgess too felt

\footnotetext{
${ }^{129}$ Cited in Howard Zinn, A People's History of the United States: 1492-Present (New York: Harper Perennial, 2003), 314.

${ }^{130}$ Daniel Coit. Gilman, James Monroe: With a Bibliography of Writings Pertinent to the Monroe Doctrine by John F. Jameson. (Boston: Houghton, 1898), 246-247,
} 
"that this nation has reached, or is at least approaching, a great crisis, in its history" with the question of how to govern the newly acquired territories. Yet he assured his readers: "I have made it reasonably clear to my own mind that the danger lies not so much in the mere possession of extra-continental territory as in the manner of its government." Burgess did not reject the idea of America ever having "colonies or dependencies," but insisted that Americans would

more nearly follow the natural order of things, if we should remain at home and attend to our own domestic affairs, set our national house in more perfect and proper order for our sovereign journey into foreign parts, and give ourselves the national discipline and development which must necessarily precede the successful performance of an international or world part. ${ }^{131}$

The Anti-imperialist movement was a minority reaction to the prospect of war, but it was supported in the nation's colleges and universities-enough so that Theodore Roosevelt, future hero of the Cuban invasion, lamented the "belated survivors of the Little England movement" who came mostly from "our educated men." 132

While some of these educated elite and mugwump reformers based their reservations on questions of state intervention in trade, and a small minority stood against intervention as a way of spreading democracy, a majority harbored racialist, social Darwinist hierarchies, and worried what

\footnotetext{
${ }^{131}$ John W. Burgess, "How May the United States Govern Its Extra-Continental Territory?," Political Science Quarterly 14 (1899), 18.

${ }^{132}$ E. Berkeley Tompkins, "The Old Guard: A Study of the Anti-Imperialist Leadership," Historian 30 (1968): $366-388$.
} 
effect a sudden influx of non-whites would have on the republic. While he considered himself "in common with the great majority" in believing that "the Spanish West Indies must break loose from Spain some day," White "had hoped that the question might be adjourned" because he "dreaded the addition to our country of a million and a half citizens whose ability to govern themselves was exceedingly doubtful." He feared the radicalization of blacks in the South once exposed to the illiterate, ungovernable "negroes and mullatos accustomed to equality with the whites." 133 Many Anti-imperialists, who understood war and annexation in largely social Darwinian terms, worried about both an influx of ignorant backwards people and the "reckless and unrestrained" populists that seemed to lack the "the manly self-control needed to govern." 134 Thus, by this time, the mugwump and historic-political school already showing an inability to adapt to changing socio-political conditions.

\section{Imperialists}

Paul Kramer has shown that "Anglo-Saxonism" reached "the height of its explanatory power in foreign policy arenas in the years immediately after 1898, when it helped cement an Anglo-American accord and provide an historical and political rationale for a US overseas colonial empire in the

\footnotetext{
${ }^{133}$ White, Autobiography of Andrew Dickson White, 162.

${ }^{134}$ Christopher Lasch, "The Anti-Imperialists, the Philippines, and the Inequality of Man," The Journal of Southern History 24, no. 3 (1958), 319-331; Kristin L. Hoganson, Fighting for American Manhood: How Gender Politics Provoked the Spanish-American and Philippine-American Wars (New Haven: Yale University Press, 2000), 170-171.
} 
Philippines and the Caribbean Sea." ${ }^{135}$ While few social scientists waded directly into the rising tide of war to support it, the opportunity it presented to build relations between America and the British was too good to resist.

Giddings was a case in point. He was a disciple of positivism and Spencerian sociology, and as such understood the development of the world as ordered by racial hierarchies of groups that developed social patterns through a mixture of natural, social and sexual selection. He imagined a more socially interdependent world, an ethical society, "peopled by diligent, respectable workmen, and philanthropic elites," and considered it his moralscientific duty to articulate the best means for moving towards such a society. ${ }^{136}$ With the Spanish defeat behind him, Giddings sloughed off American reservations about imperialism, pointing to the benefits of victory: nurturing "a consciousness of kind," by destroying American isolationism and cultivating a "good understanding and friendly alliance with Great Britain...our kinsmen over sea...our brethren and...our co-workers in the tasks of civilization." ${ }^{137}$ Never one to shy from hyperbole, Giddings defended a connection between Anglo-Saxonism and liberty but removed the emphasis on institutional transmission, choosing instead to attribute the "Anglo-Saxon love of liberty" to "the blood of the old untamable pirates that courses

\footnotetext{
${ }^{135}$ Paul A Kramer, "Empires, Exceptions and Anglo-Saxons,"1321.

${ }^{136}$ Ross, Origins, 127-129.

${ }^{137}$ Franklin H. Giddings, "Imperialism?" Political Science Quarterly 13 (1898): 595-597.
} 
through his veins." 138

Albert Bushnell Hart, a Harvard historian and H.B. Adams student, along with Simeon E. Baldwin of Yale, H.P. Judson of the University of Chicago, Henry E. Bourne of Western Reserve, and John Bach McMaster of the University of Pennsylvania, spoke in favor of an imperial policy at the 1899 meeting of the AHA. Both Baldwin and McMaster delivered papers supporting as a natural step of American historical development that was, contrary to what Burgess and other constitutionalists had argued, not excluded by the Constitution. According to Baldwin, the "inevitability" of American economic growth was behind empire, with idealism and Christian mission playing important but secondary roles. Judson advocated the full embrace of Empire, arguing that it was the surest way to guarantee economic benefit in the Philippines. For Hart, America had been "a great colonial power without suspecting it." He argued that America had established an imperial model of territorial administration, and that the Spanish-American War was "not [a sign] of a new policy, but the enlargement of a policy long pursued". He encouraged members to support rule in the colonies by an "iron hand."139

By 1899, pro-imperialists were a significant, if not controlling segment of the AEA, AHA and the American Academy of Political and Social Sciences, the vast majority building their arguments for territorial and economic

\footnotetext{
${ }^{138}$ Franklin H. Giddings, Democracy and Empire: With Studies of Their Psychological, Economic, and Moral Foundations (New York: The Macmillan company, 1900), 305.

${ }^{139}$ Gary Marotta, "The Academic Mind and the Rise of U.S. Imperialism: Historians and Economists as Publicists for Ideas of Colonial Expansion," American Journal of Economics and Sociology 42 (1983): 217-234.
} 
expansion around the idea that social science justified the enforcement of universal economic and governmental practices. At the AHA's 1899 meeting, J.B. Moore, professor of international law at Columbia and Assistant Secretary of State, criticized one anti-imperialist presenter for lacking a "historical" and "realistic" foundation for his thinking. ${ }^{140}$ At the meeting of the APSSA that same year, the serving President Edmund J. James proclaimed that, "our attitude toward all questions, no matter how practical they become, is that of the scientific mind, pure and simple." ${ }^{141}$ Roland P. Falkner, a University of Pennsylvania statistician and director of the panel discussions, went further still, positing that, "social scientists could best judge the national interest." Both James and Falkner carried forward the same impulse to direct the state in a scientific capacity that Gilman and White had advocated decades earlier. "The political authority" of the country, James noted of the war with Spain, "was compelled at more than one time to call upon the patient and thorough knowledge of the scholar."

While many of the key figures opposing colonial expansion through the Anti-Imperial League remained intractable well into the new century, a reluctantly opportunistic assessment was more common among social scientists-particularly those radiating from the Lieber circle. By 1906, Gilman proclaimed to an audience at Hopkins that, "the question of the twentieth century, is the attitude of the United States towards the islands of the sea...this

\footnotetext{
${ }^{140}$ Ibid.

${ }^{141}$ Ibid.
} 
is a question for universities and university men to illuminate." Gilman imagined that just as "England's success in India...was due to the influence of her universities," the American scholar of "geography and history" had an imperative role to play. Although still stung over the pretentions of "nations claiming to be civilized...engaged in the subjugation of those that are not," Gilman accepted that the world was becoming increasingly international and concluded that "universities", with their "historical and geographical archives," "trained investigators", and knowledge of "the principles of human progress...constitutional law and historic jurisprudence," were ideal managers for "the new problems of civil government upon which [the nation] is entering." A truly scientific mind, Gilman argued, prepared for service to the nation by knowing "not only the geographical, ethnographical, and historical facts, but [also] the principles of economics, of administration, and especially of public and constitutional law."142 Through the lens of his civicinternationalism, Gilman could make out the idea that America's new colonial possessions were fundamentally incapable of self-government, yet he imagined the social scientist playing a central role in forming new nationstates.

With his "germ" theory of democracy already under intellectual attack by former students (not least Turner), H.B. Adams watched his belief that Teutonic institutions were the carriers of democratic liberty wither under a new realist historicism across the disciplines. But he was ambivalent about

${ }^{142}$ Cited in Heyman, "Daniel Coit Gilman, Geography, and the Uses of a University," 295-316. 
overseas imperialism, and seized on the question of how to best govern new colonies as an opportunity to continue to glue college men onto the apparatuses of government inside and outside the state. ${ }^{143}$ Unlike Britain and Germany, the administration of America's Caribbean and Philippine expansion was not immediately deferred to a state-centered imperial civil service. ${ }^{144}$ Seeing this, Adams spotted an opportunity further to insert a structural place for academic expertise in spreading liberty through civilized institutions. He lobbied for former students like Emory Johnson and Jacob Hollander to join the new financial missionaries striking out to the colonies. "The eyes of the nation and, perhaps, the world are turned upon Puerto Rico" because "it is our first venture into colonial expansion," Hollander wrote to his former adviser. ${ }^{145}$ As financial advisers, these former Adams students would help develop an economic internationalism, aggressively integrating local economies into a universal (American) standard through currency and financial reform. Hollander had taken the lessons of the industrial university with him, imagining, as did historians in the $A H A$, universities taking "the leading place in shaping the financial methods of the Greater United States."

This was not a radical idea to most economists who, by 1899 , had all but purged earlier notions that socialism was the natural outgrowth of a regulatory liberalism. Instead they had come to accept that modern liberal

\footnotetext{
${ }^{143}$ Lasch, "The Anti-Imperialists," 328.

${ }^{144}$ Manicas, "The Social Science Disciplines," 71.

${ }^{145}$ Hollander to H.B. Adams, 25 April 1900 (box 8); Hollander to H.B. Adams, 16 February 1901 (box8); Also see Letter forwarded to Dr. Sherwood from H.B. Adams, originally Ely to H.B. Adams, 12 April 1900 (box 5), Adams papers.
} 
internationalism was best achieved through carefully regulated capitalism. Like Adams, Ely welcomed the "responsibilities" of America's new position, and vociferously supported both the holding of the Philippines and the active role of economists in managing of the territories. ${ }^{146}$ By 1900 , he had entirely backed down from much of his previous radicalism, writing to an audience in the Chautauqua movement that "economic internationalism is social internationalism on its business side," imagining global unification built around the extension of a cooperative but fundamentally liberal-capitalist economy. ${ }^{147}$ While Ely still believed a deeper social internationalism was at play, he now imagined "science" at the vanguard of a comprehensive liberal internationalism, spread not by particular institutions, but by the correlative forces of economic and social internationalism, each best directed by students of science, the most basic "cosmopolitan" force in the world. ${ }^{148}$

Among the ethical-economists who rejected socialism, regulatory capitalism was the new bedrock of liberal internationalism. Those who had once buttressed historicists in support of arbitration increasingly rejected Teutonism and Anglo-Saxonism as romantic historical fictions. Simon Patten argued that the notion that "civilization must be Teuton or Anglo-American in racial quality" to develop liberal practices was absurd, proclaiming that "the barriers to the expansion of civilization on which these traditions rest have

\footnotetext{
${ }^{146}$ Marotta, "The Academic Mind and the Rise of U.S. Imperialism," 223.

${ }^{147}$ Emily S. Rosenberg, Financial Missionaries to the World: The Politics and Culture of Dollar Diplomacy, 1900-1930 (Duke University Press Books, 2004), 26.

${ }^{148}$ Richard T. Ely, "Economic Internationalism," Chautauquan, February 1900 (box 2, folder 3), Ely Papers.
} 
been swept aside" by the war. For Patten, civilization was "perpetuated through traditions" rather than "through its heredity," which meant that development could not alone be measured by the history of a nation's institutions. This was not to say that Patten abandoned a hierarchical and historical view of international development. In contrast, he measured progress by holding them against the standard of modern political economicefficiency-the American state-form. "Cuba and Porto Rico [sic]" Patten proposed, "have to-day better conditions than Virginia had two centuries ago."149 History was, for Patten and many others, still a linear and singular trajectory through time towards the modern civic-state.

Patten was not alone in rejecting the Anglo-Saxonist racialistic fears of extending American sovereignty to the Caribbean and Philippines. At its 1898 annual meeting, the AEA, according to Furner, "ratified the expansion of American capitalism by appointing a blue ribbon committee under the chairmanship of J.W. Jenks, with the assistance of E.R.A. Seligman ... to work out the best means of administering colonies." 150 As did Patten, Seligman understood the world in terms of economic historical development, culminating in cooperative liberal nations. Of course, he noted that while "nations are still in unequally developed stages of industrial growth and while there remains extended markets not yet on the highroad to industrial predominance, there will still be some room for the nationalism of the old

\footnotetext{
${ }^{149}$ Simon N. Patten, "The Present Problems in the Economic Interpretation of History," Annals of the American Academy of Political and Social Science 24 (1904): 110-125.

${ }^{150}$ Furner, Advocacy and Objectivity, 276.
} 
type." Ultimately, however, the spread of basic economic principles meant that someday the "internationalism of mighty enterprises" would be realized, and they would work together towards the civilization that "can be made to exist." The internationalism of the economists represented a realist concept of liberal internationalism that was substantially more expansive and potentially intrusive than the historico-political school's civic internationalism. By positing that there were economic and social forces beneath civic institutions, the economists not only assured a bigger role for their work in the direction of government and foreign states, they also secured a more prominent space in a new social scientific internationalism.

\section{Conclusion}

The circle of historico-political scientists who followed Lieber in the 1870s continued to dominate the representation of internationalism into the $1880 \mathrm{~s}$, structuring and presenting internationalism as a juridical system of relations between civilized nations, guided by liberal principles still integral to the authority of American social science in that nation. However, in this period a second concept of internationalism grew more powerful, carried forward in the work of social scientists like Ward and Walker. As part of the Washington circle of bureau builders and national natural science associations, these social scientists began to unchain the conception of internationalism from romantic historical narratives of the progression of liberty vis-a-vis Teutonist institutions. Against rising protectionist and socialist-nationalist movements, 
and anchored less to the influence of capital than to the bureaus of the nationstate, this group modified the ontological and epistemological terrain of the social sciences in America, making a case for the tempered expansion of state capacities to manage society and the economy to curb the most obvious inequalities of the modern industrial system.

Guided by an egalitarian-Whig concept of historical progress, that still imagined progress pushed forward but still tempered by educated elites, they still placed social scientific knowledge at the core of governing nation. And, by extension, though their internationalism was rarely articulated as such, the Washington circle developed the intellectual underpinnings of an internationalism that could not abide relying on juridical institutions alone but which imagined the state actively guiding social affairs. Throughout the 1880s the pull of the new, industrially-funded university grew, fueled by the success of the historico-political school as institution builders, increasingly pulling the professional identity of the social sciences into universities and away from bureaus and legal institutions. As social scientific professionalism moved in line with academe, internationalism was increasingly guided by the first wave of German-trained historicists, who championed the ideal of America as an exceptionally stateless society that governed through Anglo-Saxon institutions. By the 1880 s and 1890s, however, the foundations of social science continued to shift, placing new pressures on the dominant political economic consensus, moving intellectuals to rationalize the rapid globalindustrial expansion and de-localized consciousness of modern America. 
The concept of liberal internationalism followed this shift, creating competing concepts of the state-society divide built around social science's attempt to maintain its own mediating role while social knowledge fragmented and developed new disciplinary boundaries. The civic internationalism that had dominated the early Gilded Age clung to a much less specialized idea of expertise bridging the state-society divide, continuing to see law and social science as two equally important prongs in creating internationalism. Much as they had in the Gilded Age, civic internationalists continued to treat internationalism as an organic system achieved through the spread of civic institutions and the practices and morality they circumscribed. The state, by this logic, was a territorialized and bounded effect that followed from civic articulations of society.

For social internationalists, the capacity to mediate between society and the state lay less in existing state-protected institutions and more in new institutions formed around social scientists, emboldened by increasing confidence in their ability to articulate more fundamental, non-localized social and economic forces. This new scientistic realism cultivated a more expansive concept of internationalism, as well as the rules that governed it. Not coincidentally, both social and civic internationalism reflected the emerging disciplinary partitions and institutions of the social sciences (divided into economics, emerging distinct political science, history and sociology by 1906). Against the backdrop of a more racially and culturally diverse populace, and hearing calls to push American power beyond the continent, 
the nation-state became, for social-internationalists, one more liberal institutional form that emerged from particular social, political and economic forces rather than from a providential march of liberty. They portrayed internationalism as a social condition in waiting, already in existence, holding the American nation-state up as the pinnacle of state-form development, the only one that could challenge both the absolute-state and the anarchy of "backwards nations."

Of course, these two internationalisms were as similar in some important ways. While they varied over which knowledges and technologies best mediated between the state and society, both variants of internationalism emerged from the overseas expansion of American empire in 1898-1902 with a firm belief in their own instrumentality and centrality in preserving a liberal order that balanced the tension between liberals global aspirations and American exceptionalism. Additionally, both emphasized gradual rather than revolutionary change, saw arbitration and legalism as imperative, and shared a faith in the significance of trade to internationalization-though, because they had different readings of the role the state ought to play as facilitator or guarantor, they often had different ideas about how it mattered in regulating trade. But unlike its civic counterpart, social internationalism deterritorializing American exceptionalism, effectively making American social values the universalistic core of a larger liberal system waiting to be realized in internationalism. Internationalism for the social internationalists was then, an extant social reality, a web of dynamic social forces that had already lifted 
Americans to a new international consciousness and which would inevitably lift the consciousness of the world to the same plane that America had already achieved by breaking with the European model. 


\section{Chapter Four:}

\section{Leaving the "Age of Nations": Social Science in an age of Global War}

...In the sense in which we have been wont to think of armies, there are no armies in this struggle, there are entire nations armed...It is not an army that we must shape and train for war; it is a nation. To this end our people must draw close in one compact front against a common foe... The nation needs all men; but it needs each man not in the field that will most pleasure him, but in the endeavor that will best serve the common good...The whole nation must be a team, in which each man shall play the part for which he is best fitted... The significance of this cannot be overstated. It is a new thing in our history and a landmark in our progress. It is a new manner of accepting and vitalizing our duty to give ourselves with thoughtful devotion to the common purpose of us all.-Woodrow Wilson, Proclamation on Conscription (1370), 18 May 1917

The only safety for democracy, faced as it is with sudden crises, is to arm itself with facts as definitely as with armies and navies. Yet this has never been done in any adequate way... James T. Shotwell, Intelligence and Politics, $1921^{1}$

Like most Americans, social scientists rushed to support Woodrow Wilson's call-to-arms in May 1917 offering their particular skills to the nation's war effort. Among the most vocal of them was a young Columbia university professor of history, James T. Shotwell. Shotwell moved to New York City in 1898, from the small town of Strathroy, Ontario, after studying at the University of Toronto, and adapted quickly to life in the big city. The Canadian attended Columbia University that year and sped through his graduate studies, becoming fast friends with his mentor and adviser, James Harvey Robinson, who encouraged him to take his Ph.D. exams. ${ }^{2}$ By 1908 , Shotwell advanced to the position of full professor at Columbia and garnered a formidable reputation for his teaching, publishing and professionalism.

\footnotetext{
' James T. Shotwell, Intelligence and Politics (New York: Century Co., 1921), 21.

${ }^{2}$ Harold Josephson, James T. Shotwell and the Rise of Internationalism in America (Cranbury, N.J.: Associated University Presses, 1975), 36.
} 
Shotwell took great pride in the prestige of his professorship. Students and colleagues remarked on his confident posture and were consistently impressed by his innovative lectures on European social history-widely acclaimed as some of the most promising work in "New History," a school earlier developed by his advisor. ${ }^{3}$ Shotwell was comfortable at Columbia, even turning down a prestigious offer to work as director of the Carnegie Endowment for International Peace in early 1917. But the rising toll of war in Europe shook him. He reacted, like so many others in his day, by arguing that the war was an opportunity to push the lessons and work he had done inside academia outward onto the world. Even before Wilson's call for mobilization, he had publicly advocated intervention on behalf of the Allies and against the autocratic regime in Germany. ${ }^{4}$ Shotwell was, however, cautious about how he involved himself, and mindful to insulate from scrutiny the professional and expert institutions he had helped and was helping to build. Like most of his colleagues, he had already looked at Germany with dismay as academics and professionals-particularly historians-became apologists for war, tools of the Kaiser Willhelm's state. German intellectuals defended German militarism and threw counter-accusations of imperialism at the Allies in a 1914 manifesto entitled "To the Civilized World". ${ }^{5}$ Robinson's ardent criticism of this

\footnotetext{
${ }^{3}$ Ibid., 44-45

${ }^{4}$ Ibid., 50.

${ }^{5}$ The manifesto was widely published in American periodicals. See, for example, Professors of Germany,

"To the Civilized World," The North American Review 210 (1919): 284-287.
} 
"prostitution" of academia to the state, which he called "pitifully feeble," left a mark on his pupil. ${ }^{6}$

For the generation of German-trained scholars before Shotwell, including those with German-trained advisers, the collapse of the German professoriate felt like a betrayal that threatened to discredit progressive networks around the world, opening them to criticism from conservatives, hyper-nationalists, populists and radicals. As Arthur Lovejoy argued, "it seems ... that the professional class, in the country where it has played the greatest part, has signally failed, at the most critical moment in German history, to perform its proper function-the function of detached criticism, of cool consideration, of insisting that facts, and all the relevant facts be known and faced." Among the American academics, the buckling of Germany's professoriate under their nation's war machine did not prove that just any state could make, break or mould a professional class. Rather, binding onto anti-German patriotism, Shotwell argued that German militarism, autocracy and imperial ambition were specifically illiberal forces that corrupted a disinterested class of professional, liberal-minded men and women by pulling them out of their civic roles and into service for the state.

And yet, despite this fear, by early 1916 Shotwell had found a group of like-minded historians and formed a semi-secret organization to promote American cooperation with the Allies, placing pro-allied propaganda in

\footnotetext{
${ }^{6}$ Cited in Carol S. Gruber, Mars and Minerva: World War I and the Uses of the Higher Learning in America, (Baton Rouge: Louisiana State University Press, 1975), 18.

${ }^{7}$ Arthur O Lovejoy, “Letter to The Editor,” The Nation 99 (1914): 376.
} 
periodicals and papers across the less Anglo-sympathetic and interventionist Western portions of continental America. ${ }^{8}$ This project, he believed, was part of the academic social scientist's responsibility: to "inform" the population by communicating the nation's sentiment loud enough to drown the din of fractious regional opinion. Shotwell was, like so many of his colleagues during the war, trying to fulfill the desire to influence the actions of his state by shaping the nation, while maintaining the professional identity of social scientists disinterested in such political and social forces. ${ }^{9}$

This chapter uses the tension between these two pulls on social scientists, leading up to and during the early days of America's entry into the war, to trace the movement of internationalism away from the civic internationalism that had dominated the Gilded Age and early Progressive Era, and towards the social internationalism that became most pronounced in Wilsonianism. The first part briefly explores the internationalism of Theodore Roosevelt (1901-1909), whose presidency took place in the middle of the shift between internationalisms. Roosevelt's conception of the international was one of power politics, but he understood the US's role through an ideology of "civilization" that had a certain uneasy affinity with the outlook of the emerging expert class. Indeed, I argue that this view was key in the transition towards new social scientific rationalizations of internationalism.

\footnotetext{
${ }^{8}$ Gruber, Mars and Minerva, 123-135

${ }^{9}$ This tension has been explored by other authors in other national contexts. For example see Poovey, $A$ History of the Modern Fact, 181.
} 
To that end, the second part of this chapter juxtaposes Roosevelt's 1912 presidential platform for a "New Nationalism" with Woodrow Wilson's "New Freedom." I propose that Wilson attracted liberal and left social scientists with his concept of intellectual leadership directing the state through social scientific expertise "outside" the state and nation. Against the backdrop of the global conflict in Europe, supporting Wilson's 1916 re-election campaign was seen as a chance to seize the mantle of internationalism from the stateentrenched, genteel intellectuals who had been integral to Roosevelt's view of the world, which was uncomfortably similar to the European style of imperialism that had led to the war. But, as the final section makes clear, these experts newly inducted into the halls of political power recognized early that their authority hinged on appearing to be separate from the state. Correspondence between key social scientists in the lead up to American entry into the war reveals how one organization-the National Board for Historical Services-managed this delicate balancing act, and served as a harbinger for the shape of international governance to come.

\section{Theodore Roosevelt, E.A. Ross and the Virtues of Civilization}

The imperial projection of American power into the Caribbean and Pacific from 1895 to the early 1900 s moved many social scientists to break away from a civic international tradition rooted as it was to the fixed structures of legalism and biological racialist ideas around Teutonism or, more commonly by then, Anglo-Saxonism. As the last chapter showed, at first this move 
towards a conception of social internationalism and away from civic internationalism was as much meant to make the case for imperial intervention overseas. But, once the United States started to speak openly of possessing an empire, talk of the right of the American state to spread civilization, the nation's maturity, and endless commercial expansion into Asia and Latin America became both more widespread and more controversial. ${ }^{10}$ The social internationalism that had helped underwrite American imperialism at the turn of the century gave way to a modified concept of internationalism that specifically emphasized American social science-with its ability to direct state policy towards a form of regulated, socially minded capitalism-as exceptionally positioned to direct international governance.

To illustrate this shift, we need look no further than the difference of thinking about internationalism between Theodore Roosevelt and Woodrow Wilson. A product of the neo-federalism that directed the development of American social science and internationalism before the turn of the century, Roosevelt had one ideological foot firmly planted in a past that was concerned with making the nation-state stronger by consolidating power through cultural reform and institution building. But as Ninkovich argues, his other foot was planted in a period of shaky transition toward a more modern, globalist world comprehensible through universal social forces. ${ }^{11}$ When in 1881 , at 23 , Roosevelt left law school to run for a seat in the New York Assembly, he

\footnotetext{
${ }^{10}$ Wiebe, The Search for Order, 241.

${ }^{11}$ Frank Ninkovich, "Theodore Roosevelt: Civilization as Ideology," Diplomatic History 10 (1986): 221222.
} 
entered into politics carrying with him a formidable education from Columbia and Harvard. There, he came of intellectual age at the heart of the old historico-political schools with their Anglo-Saxonist, Teutonist, and republican nationalist foundations. But from 1889 to his elevation to the presidency in 1901, Roosevelt's orientation, like many other social scientific thinkers during that critical period, "shifted away from romantic Anglo-Saxonism and Teutonism," and towards the realism provided by a more modern, globally conscious social science. ${ }^{12}$ For the rest of his political life, Roosevelt corresponded with some of America's most influential progressive social scientists, who shared his belief that civilization, history and the natural world could be profitably understood as a racial struggle.

Perhaps the most influential of these thinkers was the sociologist E.A. Ross. Like his adviser, Ely, Ross migrated from economics to sociology and socialism to liberalism by the turn of the century. It was then that he published an influential article on what he called "social control" in The American Journal of Sociology, a study that was followed in 1901 by a book by that title. Social control was, for Ross, the idea that there was a fundamental conflict between social interests and the interests of the individual. In order for societies to prosper or simply survive this antinomy Ross proposed that individual feelings and behaviour had to be modified to conform to the larger social organism of which they were part. As Ross argues, social control relied on a

\footnotetext{
${ }^{12}$ Thomas G. Dyer, Theodore Roosevelt and the Idea of Race (Baton Rouge: Louisiana State University Press, 1992), 9.
} 
racial analysis that must be understood as a "specific response to the Gilded Age crisis of American exceptionalism." Rather than taking on the romantic ideal of a Anglo-Saxon heritage communicating a shared ethos of liberty. This, Ross suggests, was what many social scientists imagined assured the renewal of the American republic, a constantly directed progress directed by social laws th preventing the solidification of social inequality in the state, so that while the interests of the individual remained integral to the success of society, it was understood that these had to be tempered if there was to be any hope of avoiding anarchy. ${ }^{13}$

The movement of American society into increasingly complex social, political and economic systems, stretched the bond of shared civility that kept it together, and strained the ideal that American's were bound by some virtues, inherent in the Aryan "western-European breed," handed down through a westward march of history. Rather, now, the bond of civility that would underpin an international community-like that of the nation itselfwas cultivated through a careful management of social forces, a regime of social control, that aligned the interests of the individual with those identified as essential to their larger society. ${ }^{14}$ And if social control balanced by the industrious individual was the marker of advanced civility, then America's construction of collective capitalism, rather than a state-controlled or purely laissez faire model, would assure its place at the apex of global civilization.

\footnotetext{
${ }^{13}$ Ross, Origins, 232.

${ }^{14}$ Ibid., 234-238
} 
And to get there, he said, "we shall have to develop the state, especially on its administrative side." 15

Ross's work left an indelible mark on the reform-minded President Roosevelt. "With almost all that you write I am in full and hearty sympathy," he wrote to the sociologist. ${ }^{16}$ The turn of the century was a period of American history preoccupied with the unfettered growth of corporate trusts and wave upon wave of immigration, fueled by the unprecedented scale of imperialism and global economic interpenetration. Local problems seemed increasingly tangled in a larger global web of people, capital and goods. Against this new, expanded global awareness, Roosevelt discovered in Ross a social scientific framework that understood America and the world through the lens of "civilization." The struggle to build and spread civilization made American progressives call for local regulation of capital commensurate with a kind of neo-federalism (that of nationalists, mugwumps and reform-republicans).

At the same time, they called for the global expansion of liberal values and institutions and America's own imperial expansion. Rather than the competitive individualism that typified a liberal society based on the free play of interests, the Roosevelt-Ross school imagined altruism as the distinguishing attribute of civility. "In the evolution of humanity" Roosevelt argued, "the unselfish side has on the whole, tended steadily to increase at the expense of

\footnotetext{
${ }^{15}$ Dusky Lee Smith, "Sociology and the Rise of Corporate Capitalism," Science \& Society 29 (1965): 401418.

${ }^{16}$ E.A. Ross, Sin and Society, (New York: Houghton Mifflin,1907), xi.
} 
the selfish, notably in the progressive communities."17 Ross echoed this sentiment in his own assessment, noting the importance of making altruism a core characteristic of national leadership:

Many businessmen who had been drifting with the tide came under the conviction of sin, mended their ways, and helped others to do the same. The corporations in the public eye hastily rid themselves of their discredited agents and put into charge of their affairs upright men who command public confidence. As commercial practices improved, men who had been handicapped by their scruples came to the front. $A$ new type- clean, public-spirited, and social minded- gained leadership in the business group. ${ }^{18}$

Such character was crucial to the equilibrium needed for American civilization to survive and prosper. Portraying the success of American civilization as contingent on the cultivation of a collective, nationalistic and patriotic selflessness essentially redefined the meaning of civilization. Gone were its deterministic, laissez-faire connotations, and in their place was a purposeful and forceful meaning that justified both domestic regulation and foreign intervention by the state. ${ }^{19}$

This attempt to justify social control and regulated, ethical capitalism as imperative to American civilization also made Roosevelt a major figure in the conceptual expansion of American internationalism into a global system, rather than a system limited to juridical relations between "civilized" nationstates. A modified rationale for imperialism fit with and indeed facilitated this worldview. It harmonized the new liberal yearning for modern order,

\footnotetext{
${ }^{17}$ Cited in Ninkovich, "Theodore Roosevelt," 230.

${ }^{18}$ E.A. Ross, What is America? (New York: Century Co., 1919), 100-104.

${ }^{19}$ Ninkovich, "Theodore Roosevelt," 231.
} 
cooperation, and rationality with the republican emphasis on the exercise of pre-modern, manly virtues. Like Ross, Roosevelt was not a biological racist and did not justify imperialism with the clunky, determinist categories many would recognize as social Darwinism. He accepted Darwinism as a biological theory but not its determinist socio-biological corollary. Race was not an insurmountable biological barrier to civilization and modernity. Instead, so long as it was possible to understand the potential in all traditional societies, it was possible to aid in the evolution of barbarian and backwards nations towards a civility that would ameliorate petty tribalism. ${ }^{20}$

This view of civilization had immense consequences for American concepts of internationalism. By arguing that civilization was an imminently modern system common to the progress of all mankind, Roosevelt shifted internationalism to a social (i.e., about the people, customs and norms) rather than purely civic (i.e., existing institutions and laws) rationalization. Measuring "each international question against the backdrop of those tendencies through which civilization develops and along which particular civilizations advance or decline," internationalism had to include those as-yet uncivilized zones of the world, which America had an obligation to uplift. ${ }^{21}$ As Gerstle argues, Roosevelt's combative and unapologetic racial ideology was such that when he "undermined the foundations for [other] countries' independence,

\footnotetext{
${ }^{20}$ Ibid., 232.

${ }^{21}$ Elihu Root, "Roosevelt's Conduct of Foreign Affairs," ed., Hermann Hagedorn, The Works of Theodore Roosevelt (New York, 1925), 16: xii, xx.
} 
he merely acted upon a belief that barbarians were barbarians." 22 But, by extension, if international questions used civilization as a socio-political standard that encompassed the world, then the unity of space and time it created to justify imperialism also "obliterated the geographical, cultural, and temporal distinctions between old and new worlds." Roosevelt did not accept the imperialism that pitted civilized powers against one another, because force, if justified purely in terms of power, was barbaric and opposed to the interests of civilization. Thus he maintained that much European imperialism was "merely political, and such a conquest is always in the long run to vanish." ${ }^{23}$ But conquest, as he had written about years before in his story of America Winning of the West, still ensured cultural and psychological renewal of a civilization so long as it continued elsewhere. ${ }^{24}$ As he put it in a work on "Biological Analogies in History," so long as it understood that all political conquest was secondary to larger "ethnic conquests," the US would have a role among the community of civilized nations. ${ }^{25}$

Of course, Roosevelt was not so naïve as to think possible an international system without conflict among civilized nations. He was skeptical of the broad applicability of arbitration, arguing that "Nations may, and often

22 Gary Gerstle, "Theodore Roosevelt and the Divided Character of American Nationalism," The Journal of American History 86 (1999): 1280.

${ }^{23}$ Ninkovich, "Theodore Roosevelt," 235.

${ }^{24}$ Theodore Roosevelt, The Winning of the West (New York: Putnam, 1889). For a strong analysis of the shift in Roosevelt's own thinking between this work and his later attempts to synthesize American participation in state centred imperial expansion see Roger L. Nichols, "Thodore Roosevelt and the Indians," ed. Serge Ricard, A Campanion to Theodore Roosevelt, (New York: Wiley Blackwell, 2011), Chapter 11.

${ }^{25}$ Theodore Roosevlet, History As Literature and Other Essays, (New York: Charles Scribner's Sons, 1913), 76-77. 
must, have conflicting interests. ${ }^{26}$ But his optimistic imperialism nevertheless depended upon the absence of total conflict between the great powers, and it used this peace to justify America's importance in globalizing the base of the European balance of power, in order to ensure the collective security of civilization. In this way, Roosevelt's innovation was transitional, but limited. It moved closer to a social scientific rationalization of the world as universally connected and knowable by basic social principles, but it remained tethered to past social science preoccupations with the "civilized nation" as part of a larger march of ethnic conquest. Roosevelt bucked much of the language and romanticism of earlier Anglo-Saxonists, but he still believed America's role in the larger global balance of power was to maintain the forward momentum of Anglo-Saxon culture, which Roosevelt placed at the cutting edge of history across the world. ${ }^{27}$

For a growing number of social scientists and progressives, however, the president's formula of internationalism as civilization too clearly blurred the lines between state and society, justifying the social control of individuals by the administrative social solidarity (be it a nation or an empire) provided by the state. Just as the historico-political school had earlier done in limiting its understanding of the international to the territorial, juridical nation-state,

\footnotetext{
${ }^{26}$ Cited in Frank Ninkovich, Modernity and Power: A History of the Domino Theory in the Twentieth Century (Chicago: University of Chicago Press, 1994), 14. Ninkovich points out, using this and other examples where Roosevelt voiced scepticism about the ability to mediate international conflicts, that Roosevelt was not a true believer in the benefits of arbitration.

${ }^{27}$ As Dyer notes, Roosevelt remained oblivious to the even more liberal globalism of a younger generation of anthropologists like Roland B. Dixon and Franz Boas--both of whom would have a more direct intellectual relationship with Woodrow Wilson and his internationalism. Dyer, Theodore Roosevelt and the Idea of Race, 18.
} 
Roosevelt now fixed internationalism to the community of civilized nations able to conquer other states in the name of spreading civilization.

\section{The 1912 Presidential Election: New Freedom versus New Nationalism and Cracks in Social Internationalism}

The discomfort with the formula of social internationalism championed by the likes of Roosevelt becomes most apparent in looking closely at the presidential election of 1912. It was then that the Republican Party divided along its progressive-reformist and conservative wings. After losing the party's presidential nomination to William Howard Taft, Roosevelt divided the GOP by forming a Progressive Party bolt (known as the Bull-Moose Party), opening the way for Wilson's Democratic ticket to walk up the middle in the election. As Roosevelt moved more deeply into progressive ideology so as to differentiate himself from Taft, the distance between his Bull-Moose platform and Woodrow Wilson's Democrats became more nuanced, and the distinctions more revealing. Both leaders put forward ambitious philosophical and federalist platforms that year, with Roosevelt advocating a "New Nationalism," and Wilson the equally ambitious "New Freedom." Their visions differed with respect to the key question of what was to be done with America's increasingly powerful business trusts and the role of the state in regulating them. Roosevelt's New Nationalism proposed regulation by a strong central government. Wilson, by contrast, argued that trusts be weakened through legislation that both limited the influence of the state while 
building greater competition in the economy. As Wilson summarized the difference in one 1912 speech, "Ours is a program of liberty, and theirs is a program of regulation."28 That year, most progressives and reformrepublicans were drawn to Roosevelt's vision of New Nationalism, which many argued could better harness the benefits of industrial concentration while building the power of a strong, reform-driven federal government. ${ }^{29}$

Differences in rhetoric aside, the two visions for national order were more alike than dissimilar. Most salient for this dissertation, both were ultimately supportive of the idea of an inner circle of disciplined managers determining affairs. ${ }^{30}$ As John Milton Cooper has noted of the RooseveltWilson conflict, the disagreement was largely over "the proper method of leadership and, thereby, the true purpose of government."31 For Roosevelt, the purpose of leadership was a paternalistic one (resembling what we now recognize as Toryism): to inspire and work through government to unify a people that might otherwise be divided by parochial identities, cultural habits, and worldviews. ${ }^{32}$

Roosevelt's New Nationalism proudly embraced the Hamiltonian political model advocated in Herbert Croly's acclaimed progressive work,

\footnotetext{
${ }^{28}$ James Chace, 1912: Wilson, Roosevelt, Taft and Debs -The Election That Changed the Country (Toronto: Simon \& Schuster, 2004), 56-62.

${ }^{29}$ See, for example, Walter Lippmann's biting criticism of the New Freedom as nostalgic and populist in, Drift and Mastery, 81-83.

${ }^{30}$ Wiebe, The Search for Order, 286.

${ }^{31}$ John Milton Cooper Jr., The Warrior and the Priest: Woodrow Wilson and Theodore Roosevelt (Cambridge: Belknap Press, 1985), 212-214 emphasis added.

${ }^{32}$ Gary Gerstle, "Theodore Roosevelt and the Divided Character of American Nationalism," The Journal of American History 86 (1999): 1307.
} 
The Promise of American Life (1909). Common sense and common laws were promoted in efforts to build a robust nation-state in the image of its most virtuous individuals. As Roosevelt wrote as a crusading public reformer in New York City in 1895: "We need intellect, and there is no reason why we should not have it together with character." On the other hand, he qualified, "if we must choose between the two we choose character without a moment's hesitation." ${ }^{33}$ And character, for Roosevelt, was proven in struggle for a more democratic and just society.

Within an understanding of international relations, this link between strong individual character and the cultivation of a strong juridical nation-state was seen as the embodiment of "civilization", and as fundamental to international peace. "Every expansion of a great civilized power," Roosevelt claimed, was "a victory for law, order, and righteousness." 34 By balancing the world-encompassing potential of civilization with the insistence on sovereignty residing in the liberal nation-state (rather than at the local or supranational level), Roosevelt appears a modern internationalist, adapting American foreign policy to a community of nations where bald state force defined balance-of-power politics. But Roosevelt juggled this idea alongside a persistent American exceptionalism, which held up the US as the nation state

\footnotetext{
${ }^{33}$ Theodore Roosevelt, "Responding to the social theories of Benjamin Kidd in 'Kidd's 'Social Evolution"' The North American Review 464 (1895): 109.

${ }^{34}$ Theodore Roosevelt, "Paper delivered during the American Sociological Congress, Washington, DC, 2831 December, 1914," The Writings of Theodore Roosevelt, 357; Frank Ninkovich, "Theodore Roosevelt," 232-34.
} 
where the liberal subject had already and most successfully become the core of sovereignty and community. ${ }^{35}$

Substantively, seizing on cultural anxieties about immigration and masculinity at the turn of the century, Roosevelt hinged the success and identity of the American nation-state on breaking with European culture, and therefore cultivating a concept of civilization that was synonymous with Americanism. "It is because certain classes of our people still retain their spirit of colonial dependence on, and exaggerated deference to, European opinion, that they fail to accomplish what they ought to," he argued in his 1894 "True Americanism." "The man who becomes Europeanized, who loses his power of doing good work on this side of the water, and who loses his love for his native land, is not a traitor," he continued, "but he is a silly and undesirable citizen. He is as emphatically a noxious element in our body politic as is the man who comes here from abroad and remains a foreigner." 36

For Roosevelt, the civilizing of far off lands was an obligation that was best fitted to the capacities of Americans - especially the "soldiers and statesmen and orators," explorers, "wilderness winners," and "commonwealth-builders" who made American law, who had "done better work than has been done in any other country during the short period of our national life. ${ }^{37}$ Thus, the renewal of American democracy was not realized by simply spreading American civilization into the continental West or the Pacific

\footnotetext{
${ }^{35}$ Ninkovich, "Theodore Roosevelt," 233-235.

${ }^{36}$ Theodore Roosevelt, "True Americanism," The Forum Magazine, April, 1894, 1-4.

37 Ibid.
} 
or Caribbean. Rather it was renewed through the individual's manly struggle to bring such civility to the world - a process that checked the possibility of a "flaccid" over-civilization of the nation's leaders. The ramifications this line of thinking had for the professionalizing social sciences are important. Roosevelt took great pleasure in ostracizing and emasculating any in the American intellectual class who appeared to him as sycophants to European culture:

...it is in those professions where our people have striven hardest to mold themselves in conventional European forms that they have succeeded least; and this holds true to the present day, the failure being of course most conspicuous where the man takes up his abode in Europe; where he becomes a second-rate European, because he is over-civilized, over-sensitive, over-refined, and has lost the hardihood and manly courage by which alone he can conquer in the keen struggle of our national life. Be it remembered, too, that this same being does not really become a European; he only ceases being an American, and becomes nothing. He throws away a great prize for the sake of a lesser one, and does not even get the lesser one. ${ }^{38}$

The advance of civilization by any great power was, by this thinking, beneficial. But only Americans possessed the virtues that cultivated muscular individual character and, by extension, protected the nation state from the decline that happened with over-civilization. Although he was much more receptive than previous presidents to the wave of new immigrants coming to America, the ethnocentrism and provincialism of Roosevelt's vision became apparent in its hostility to those progressives who imagined a more cosmopolitan-liberal world. Roosevelt's stand against those self-identified

\footnotetext{
${ }^{38}$ Ibid., 3.
} 
internationalists and cosmopolitans was clear: "Nothing will more quickly or more surely disqualify a man from doing good work in the world than the acquirement of that flaccid habit of mind which its possessors style cosmopolitanism."

Roosevelt's foreign policy remained focused on enforcing hemispheric or regional supremacy (for America and around the world), taking on a systematic view of international relations as "spheres of influence." ${ }^{39}$ This view may have been partly inspired by Croly's Promise of American Life, particularly the latter's focus on destroying American isolationism as a means to further the modernizing of America. But Croly placed global selfdetermination at the core of a world system; Roosevelt, in contrast, interpreted Croly's call for global pan-Americanism as a recommendation that the more civilized US should dominate the Western Hemisphere. ${ }^{40}$

Wilson's vision stands noticeably apart from these other two. Granted, he too was impressed by Croly's Promise of American Life-particularly its insistence that greater democracy, the promise of America, was best achieved using "Hamiltonian means towards Jeffersonian ends." But Wilson's interpretation of this maxim placed a different emphasis on leadership and the methods it employed so that he spoke to a very different, emergent concept of governance. Most notably, he emphasized intellect over character in

\footnotetext{
${ }^{39}$ The League to Enforce Peace was perhaps the most powerful embodiment of the common-law and nationalistic view of internationalism in the World War One era. See Hamilton Holt, "The League to Enforce Peace" Proceedings of the Academy of Political Science in the City of New York 7, The Foreign Relations of the United States: Part I (1917), 65-69;

${ }^{40}$ Herbert David Croly, "A Stable American International System," The Promise of American Life (New York: Macmillan, 1911), 300-307.
} 
leadership of the state. For Roosevelt, Croly's call for elite national leadership was about instilling a more virtuous character into the nation's political and commercial leaders. Wilson, however, imagined an entirely different cadre of intellectuals serving as Hamiltonian leaders working towards Jeffersonian ends. He seized on Croly's ideal of the presidency and federal executive as conduits and managers of the nation's "component parts."41 Unlike Roosevelt, who wanted to breathe new character into an existing political class, Wilson wanted to make room for the educated, transnational, and cosmopolitan liberal scientist as the pillar of a new, non-partisan international. When he ran against Roosevelt in 1912, Wilson insisted that political leadership be guided by a disciplined intellect able to balance the multiplicity of voices in a nationa president able to gauge, weigh, and channel public opinion. While campaigning in Buffalo, Wilson told a crowd he had never known any "small body of men" who could claim fully, on their own, to understand the United States. "The only way the United States is ever going to be taken care of," he remarked, "is by having the voices of all the men in it constantly clamorous for recognition" of justice as they it. ${ }^{42}$ Wilson jettisoned Roosevelt's emphasis on virtuous, charismatic guardians of character replaced it with the ideal of

\footnotetext{
${ }^{41}$ Wilson, cited in Trygve Throntveit, "“Common Counsel': Woodrow Wilson's Pragmatic Progressivism, 1885-1913," ed., John Milton Cooper, Reconsidering Woodrow Wilson: Progressivism, Internationalism, War, and Peace (Washington D.C.: Woodrow Wilson Center Press, 2008), 44.

${ }^{42}$ Woodrow Wilson, "Speech at Buffalo," 2 September 1912, in Arthur Link et al., eds., The Papers of Woodrow Wilson (hereafter PWW), 69 vols. (Princeton: Princeton University Press, 1966-1994), 25: 75.
} 
expert administrators, channeling popular opinion-without shaping it for partisan political purposes-into the state. ${ }^{43}$

This vision of a more scientific, post-partisan political manager attracted progressives on the eve of war. Croly, Lippmann, Walter Weyl and other influential progressive publicists who had once thought Wilson to be of an entirely different mind than their progressive movement, were supporters by 1916. Facing the growing din for intervention in Europe, they recognized in Wilson's vision an opportunity-what Croly had named, almost a decade earlier, "the political condition which would enable the European nations to release the springs of democracy." 44 American progressives gradually came to see Wilson's presidential agenda as congruent with their own. Specifically, as one historian has noted, Wilson's emphasis on the need for the state to grow and change with society meshed his world view with other progressives' observations that "the political economic and social spheres were as interdependent as the individuals inhabiting them." 45 Those who recognized this interdependence could not legitimately support a vision of politicians leading on principle of character. Nor could they support a crusading and paternal state in an age of war that many felt had been brought on by such a system. It was easier, more rational, to buy into Wilson's vision of politics and the state as "nothing but a systematic attempt to keep the law

\footnotetext{
${ }^{43}$ For more on Wilson's emphasis on public opinion and liberal administrative functions for the state see Ross, Origins, 277-288; James Farr, "Political Science and the State," in Discipline and History: Political Science in the United States (Ann Arbour: University of Michigan Press, 1993), 68-70; Cooper, The Warrior and the Priest, 214-216.

${ }^{44}$ Croly, Promise of American Life, 313.

${ }^{45}$ Throntveit, "“Common Counsel,"” 25-28.
} 
adjusted to the real facts [and] behind the ... forces of society." And, as Wilson made clear, "you cannot do that unless you understand society."46

The Great War: The Social Science of American Exceptionalism in a time of war

Wilson won the presidency in 1912, and for the first two years he focused on domestic progressive reforms, building a successful legislative agenda around economic regulation. But with the outbreak of war in 1914, peace and preparedness came to dominate the concerns of America's fractious elite, who butted heads across pro-peace and pro-preparedness lines. In the first year of the war, Wilson sought to steer a neutral course between the Allies and Central Powers and, domestically, strong pacifist and martial factions. He wanted to be less aggressive in his international policy than Roosevelt, but nevertheless confronted the challenge of repeated confiscations of materials headed for Germany by the U.K, and, in the aftermath of the torpedoing of the Lusitania, the tragic killing of hundreds of American citizens in May 1915 by a German submarine. ${ }^{47}$

As one historian notes, while the war was unlike any of the previous economic and social problems faced by the nation's divided elite, it turned to the tried and tested role of civic-organizations to guide American state policy

\footnotetext{
${ }^{46}$ Woodrow Wilson, quoted in "Wilson Exhorts the Foreign Born: Address to in Chicago to Nonpartisan Women," New York Times, 20 October 1916, 1.

${ }^{47}$ Justus D. Doenecke, Nothing Less Than War (Lexington: University of Kentucky Press, 2011), 11-22.
} 
and internationalism to circumvent the state and inform popular opinion. ${ }^{48}$ The first private group to try to form such a civic organ in the US was the Woman's Peace Party (WPP). Made up of suffragists, Women's Trade Union League members, and Socialists, it was led by the influential Chicagoan feminist and immigration reformer, Jane Addams. The group attempted to bypass the traditional international relations infrastructure, which had been established by the aforementioned Mugwump reformers of the 1890 s and early 1900 s, by calling members of The Hague International Woman Suffrage Alliance to join them in visiting European heads of state in the neutral nations. After the conference, two delegations of women traveled across Europe advocating an international conference of neutrals forcing warring states to peace. One traveled to neutral nations, the other to belligerents. As the best-known woman in America, Addams and her fellow activists had cultivated an impressively wide network of sympathetic reformers across the globe. And her work in visiting the belligerents left her hopeful that mediation was possible. ${ }^{49}$ Wilson and his administration, however, balked at the proposal brought by Addams and her colleague, Emily Greene Balch, for a conference of all parties. Wilson worried about the timing, and that, should the conference fail, it would cost America influence among the belligerents when

\footnotetext{
${ }^{48}$ Nell Irvin Painter, Standing at Armageddon: The United States, 1877-1919 (New York: Norton \& Company, 2008), 306.

${ }^{49}$ David S. Patterson, The Search for Negotiated Peace: Women's Activism and Citizen Diplomacy in World War I (New York: Routledge, 2008), 46-52.
} 
it counted most..$^{50}$ And for a president who increasingly relied on the social knowledge created in circles of predominantly male social scientists whose legitimacy and authority was anchored to the highly gendered space of the university and professional associations, peace efforts-particularly those led by women-that did not bind on to existing social values around the gendered nature of intelligence were a threat to Wilson's credibility. ${ }^{51}$

Not long after the WPP began their efforts to secure peace through mediation, several prominent male politicians and intellectuals worked to move America towards a more formal international system of arbitration through the League to Enforce Peace (LEP). Composed of members of the staid pre-1914 peace movement, the LEP called for a League of Nations backed by arbitration and, if necessary, economic and military force. Their proposal gained significantly more influence than the WPP's calls for a perpetual conference of nations. But the LEP was not shy about its allegiances in the war. Heavily favoring the Allies and arguments for American preparedness, its members were more concerned with using American

\footnotetext{
${ }^{50}$ Lansing to Wilson, 1 September 1915, PWW, 34:397-99; Wilson to Lansing, 31 August 1915 PWW, 34 : 399; for more see Doenecke, Nothing Less Than War, 99-100; Patterson, The Search for Negotiated Peace, 133.

${ }^{51}$ For the gendering of history practices and the pressing out of women see Bonnie Smith, The Gender of History: Men, Women and Historical Practice (Cambridge: Harvard University Press, 1998). For a wider look at the importance of gender in the formation of the social sciences see Helene Silverberg, Gender and Social Science: The Formative Years (Princeton: Princeton University Press, 1998). See especially, Dorothy Ross's chapter on "Gendered Social Knowledge: Domestic Discourse, Jane Addams, and the Possibilities of Social Science," 235-264.
} 
power to shape a peace in favour of America so that liberal nations could more assuredly enforce peace. ${ }^{52}$

While much of his cabinet was receptive to the LEP, Wilson treated it much like he did other civilian organs-as one voice among many others in a larger social sphere that composed the nation. This made Wilson, John Milton Cooper argues, a most dexterous manager of institutionalized world views, "surprisingly sensitive to organized pressures from all sources" and able to manage populations as interest groups with sometimes intersecting and sometimes divergent interests. ${ }^{53}$ The anti-paternalism Wilson had directed at Roosevelt during the 1912 election was, therefore, more than just a tool to differentiate himself from Roosevelt in the eyes of the electorate. Unlike the Bull-Moose Progressives, Wilson's campaign and his administration maintained an impressive if uneasy alliance of progressives, liberals and conservative-nationalists of the Roosevelt wing of the Republican Party alongside devoted pacifists. ${ }^{54}$ Relegated to just one part in a chorus of voices in the political sphere, influential figures in the LEP soon began to voice feelings of marginalization, and to turn slowly but surely on Wilson.

For his part, the president did gradually come around to the LEP's message of preparedness for war before the US entered the fray in 1917, and

\footnotetext{
${ }^{52}$ Painter, Standing at Armageddon, 306-319.

${ }^{53}$ Cooper, The Warrior and the Priest, 216.

${ }^{54}$ Ibid., 183-195.
} 
from 1914 until 1919 he openly courted its support for a League. ${ }^{55}$ He was distrustful of the pro-allied organization, which he believed would push the state into war, and towards a very particular League system that risked reifying the power politics that had caused the war in the first place. But the president came around to the idea of preparedness before much of the general population had in 1915, and to nurture the broad political allegiance between pacifists, labour, democratic populists, breakaway Socialists, progressives and liberals who would carry him to his 1916 victory against Charles Evan Hughes, the president played up his role in protecting American neutrality. Still, far from courting the conservative Republican base of the LEP, Wilson's campaign used Roosevelt's and Hughes's support for its message of preparedness as foil for his own slogan, "he kept us out of war." After the 1916 election, as Wilson carried the US towards war in 1917 and his political alliance with much of the nation's left began to melt away, he maintained the partisan rancor left over from that election, continuing to distrust key LEP officials including, not least, Harvard President A. Lawrence Lowell and former President Howard Taft.

Beyond these partisan and strategic concerns, on an ideological level Wilson was also deeply suspicious of the close interpersonal connections between the LEP and British representatives he used in own communications with the British government. The President and Colonel House had had very

\footnotetext{
${ }^{55}$ Painter, Standing at Armageddon, 318; "Wilson Praises Support: Cables His Appreciation to the League to Enforce Peace," New York Times, 15 February 1919.
} 
amicable relations with Lowell and the LEP. They spoke highly of the group's work building support for the League and sought Lowell's opinion on staffing the Inquiry in $1917 .^{56}$ But by 1918 , Wilson became more distrustful of Lowell and the LEP enclave after he received the Phillimore Committee report from British Prime Minister David Lloyd George. That report, which had been coolly received by Lloyd George but handed on to the Americans, called for a post-war League built on a formal "alliance" that would guarantee peace as a principle among its members while selectively enforcing it elsewhere through embargos, mediation and arbitration. House secretly leaked news of the British Commission to the LEP in the hopes that Lowell and other influential voices might sway Wilson out of his lingering ambivalence towards Britain and formal plans for a League. ${ }^{57}$ Wilson, however, interpreted the LEP's knowledge of the report as proof that the group was working too closely with key British contacts near his administration. He demanded these liaisons cut all contact with the LEP. He also called on House to request advice on how to outline the principles for a League of Nations from the small working group known by then as the Inquiry, rather than the legal experts of the LEP. Wilson's move not only hobbled the LEP's influence and marginalized much of the civilian peace and preparedness movements, but, more fundamentally,

\footnotetext{
${ }^{56}$ Gelfand, The Inquiry, 28.

${ }^{57}$ John Milton Cooper Jr., Breaking the Heart of the World: Woodrow WIlson and the Fight for the League of Nations (New York: Cambridge University Press, 2001), 27-29.
} 
his deferral to the Inquiry signaled a shift in the epistemological foundations of internationalism. ${ }^{58}$

Wilson rejected the terms for a league set out by the LEP and British elites in the Phillimore report. Instead his drafts leading up to the peace conference proposed that a League "covenant" be built on the pillar of selfdetermination, a concept dearer to progressives, liberals and socialists around the world than conservative nationalists in the US. Lippmann and a small number of progressives working in the Inquiry had consistently inserted the language of self-determination into early drafts of the Fourteen Points Speech and the League Covenant. While Wilson personally revised much of the language, the basic shape of his proposed Covenant eschewed the ideas of a world court and judicial settlements through arbitration as mechanisms for settling international disputes. In their place, as early as September of 1918, Wilson proposed a League with self-determination at its core, bound by a Covenant that guaranteed equal representation for nations great and small, strengthened requirements for disarmament and arbitration, and guaranteed all nations the right to territorial and political independence. ${ }^{59}$

Wilson's faith in the potential to separate administration from politics and existing social interests must be understood as part of a larger shift in thinking about government in the lead up to the war. As Robert Wiebe has noted, the result was a bureaucratic vision of society as "ceaselessly

\footnotetext{
${ }^{58}$ Lloyd E. Ambrosius, Woodrow Wilson and the American Diplomatic Tradition: The Treaty Fight in Perspective (New York: Cambridge University Press, 1990), 39-50.

${ }^{59}$ Cooper, Breaking the Heart of the World, 29.
} 
interacting voluntary groups assisted in their course by a powerful, responsive government. The people still existed, it was assumed, giving the nation its mystic coherence, but day-by-day administrators would deal with them in rational subdivisions." ${ }^{160}$ Wilson imagined politicians, and especially the president, "registering, interpreting, and acting upon public opinion to facilitate informed and efficient collective action." 61 The belief in the disciplined politician-as-conduit-of-public-opinion made national political machines and even legal systems seem provincial when held against the cosmopolitan consciousness of the disciplined administrator. By this thinking, institutions like the League to Enforce Peace were important civic voices, but still singular if not narrow interests masquerading as universalistic embodiments of the nation.

Building internationalism around this administrative governance demanded a simultaneous mastery of the state and the appearance of distance from its entrenched power structures, which seemed wed to particular interests. "No group of directors, economic or political, can speak for a people," Wilson told an audience in 1916, who had neither the "point of view" or "the knowledge to presume to speak for the nation." To offer his own prescription on how to harmonize the constituent and provincial interests in the state, as early as 1917 Wilson turned to a group that seemed capable of unearthing the deeper synthesis of society through what he termed a

\footnotetext{
${ }^{60}$ Wiebe, Search for Order, 222.

${ }^{61}$ Trygve Throntveit, "Common Counsel,'"35.
} 
"humane empiricism." ${ }^{2}$ Turning to the generation of social scientists that came of academic age with him in the 1890s and 1900s, Wilson found experts that appeared non-partisan, more concerned with the scientific administration of the state than with political influence over it.

This difference in the art of governance, largely revolving around the question of what sources best articulated the interests of the nation without serving interests that could easily ossify into an autocratic state, festered within the splintering progressive movement from 1912 and into 1918. But it became increasingly clear in this period that international institutions built around the ideal of Anglo-Saxon values (be it civic-culture or juridical tradition) were not the spring of international democracy many had once hoped they were. In place of those institutions a new guard of more positivist and realist internationalists emerged. Capitalizing on Wilson's own desire to distance American internationalism from entrenched political and societal forces, they made their disciplines and the American understanding of internationalism both more expansive and more grounded to the study of social forces as it was practiced and ontologically organized by professional social scientists in the US.

As previous chapters noted, where once American exceptionalism had been built around the glorification of a civic culture that was seen as historically inherited through a Teutonic or Anglo-Saxon march of history, by 1902 these justifications were in decline, and by the outbreak of the Great

\footnotetext{
${ }^{62}$ Ibid., 36.
} 
War any lingering romantic appeal became a liability for any who wished to influence the governance of the state and nation. ${ }^{63}$ Among the general population in the US, Wilson's decision to enter into war was met more by feelings of resignation than enthusiasm. But a small group of intellectualsprofessors, physicians, clergymen, and lawyers-took a much more enthusiastic stance-almost ghoulish-doing what one author in the New Republic called "the effective and decisive work on behalf of war." many of America's economic, political and intellectual elites, the cataclysmic scale of the war was unfortunate.

But the war was, for many liberals and progressives, also an opportunity for American democracy to prove its potential as a model for the world; a chance to challenge the European balance of power system and fundamentally to rethink, in favour of a more "liberal" order, the rationality of governance that underpinned internationalism. Walter Hines Page, the proEntente ambassador to London, told Wilson in 1916:

The great tide of the world will, by reason of the war, now flow towards democracy-at present alas! $A$ tide of blood. For a century democracies and Liberal governments have kept themselves too much isolated, trusting prematurely and too simply to international law and treaties and Hague conventions....our championship of democracy must lead us to re-declare our faith and to show that we believe in our historic creed. Then we may escape falling away from the

\footnotetext{
${ }^{63}$ For more on the apex and nadir of Anglo-Saxonism in American internationalism see Anna Maria Martellone, "In the Name of Anglo-Saxondom, For Empire and For Democracy: The Anglo-American Discourse, 1880-1920," in Reflections on American Exceptionalism, ed. David K. Adams and Cornelis A. van Minnen (Stafforshire, England: Keele University Publishing, 1994). Kramer, "Empires, Exceptions and Anglo-Saxons," 1321.

${ }^{64}$ Cited in Doenecke, Nothing Less Than War, 297.
} 
Liberal forces of the Old World and escape the suspicion of indifference to the great scheme of government, which was set up by our fathers' giving their blood for it. I see no other way for us to take the best and biggest opportunity that has ever come to prove true to our faith as well as to secure our safety and the safety of the world. ${ }^{65}$

Like Page, prominent social scientists also framed the war as an opportunity for liberal democracy as a virtuous alternative to a new international that redressed the failures of the old hyper-nationalist and imperialist system. The world was never more consciously interconnected than it had become by the war, argued Franklin Giddings, and citizens of the world had come to realize that this was a battle between "democratic and dynastic nations." ${ }^{16}$ Giddings's Manichean divide complimented the hyper-nationalism of conservatives and some Bull-Moose progressives who, led by strong advocates such as former presidents Roosevelt and Taft, pushed for intervention and preparedness as a way of cementing American identity around a shared national purpose. ${ }^{67}$ It also worked well for liberal internationalists such as John Dewey, the philosopher, sociologist and pedagogical reformer, who rejected the notion that the ultimate benefit of the war was a more cohesive nationalism, and instead imagined it as an opportunity to cement an international consciousness and accompanying state structures. "Whatever the immediate decisions of the

\footnotetext{
${ }^{65}$ Walter Hines Page to Woodrow Wilson, 24 November 1916 (folder 1482), Walter Hines Page Papers, Houghton Library, Harvard University, MS Am 1090.1. (Hereafter referred to as Walter Hines Page Papers)

${ }^{66}$ Franklin H. Giddings, "The Bases of a Just and Enduring Peace," The Annals of the American Academy of Political and Social Science 72 (1917): 83-88.

${ }^{67}$ David M. Kennedy, Over Here: The First World War and American Society (New York: Oxford University Press, 2004), 17-19.
} 
statesmen who sit in the peace conference," he wrote in 1918, "at the end of the war...an international state is on its way." 68 There were important ideological differences over what governmental and political system ought to emerge from American intervention in the war. But there was little doubt among most liberals and many progressives that the war presented America with an opportunity.

But, for many, this sense of opportunity hinged on their ability to steer the American state towards the magnanimous position that proved it exceptional, and to (re)-present the US as a truly altruistic player in the war and eventual peace. Both of these goals, many social scientists understood, hinged on convincing both Americans and the world that a system of states could achieve international peace without resorting to the old imperial, statist system that many felt had been the very cause of the Great War, and by presenting American social scientific management as integral to the composition and success of an alternate system. ${ }^{69}$ Dewey, for example, proposed that a full break with the past international system would have to realize, "a better organized world internally as well as externally, a more integrated, less anarchic, system."70 The old fixed ways of knowing the world "have been shocked into disintegration," he said, "and certain factors in society, especially labor on one side and scientific competency or

\footnotetext{
${ }^{68}$ John Dewey, "What are we Fighting For," Independent 94 (1918): 480-483.

${ }^{69}$ James A. Nuechterlein, "The Dream of Scientific Liberalism: The New Republic and American Progressive Thought, 1914-1920," The Review of Politics 42 (1980): 167-190; David A. Hollinger, "Science and Anarchy: Walter Lippmann's Drift and Mastery," American Quarterly 29 (1977): 463-475.

${ }^{70}$ Dewey, "What are we Fighting For," 483.
} 
intellectualized skill on the other, have been quickened by the strains of great social emergency to a sense of their pivotal place." Labor and the new scientific order, Dewey imagined, would replace the old parochial "rationalization of history and institutions, especially of the state," which had been used to justify imperialism and conflict would be put to rest. In its place would emerge a world order built on a "science of ideas in action."11

Dewey was far from alone in his optimism about the transformative capacity of a science of society. In a global atmosphere that pleaded for change, the hope that America, acting as mediator, could achieve what one diplomat called a "scientific peace" seemed very real, and very necessary. Across the Western world, intellectuals and the general public called for a more scientific approach to governance that could "make the world safe for democracy", undermining the power of autocratic states by attacking their epistemological foundations. ${ }^{72}$ As I show next, American social scientists working toward this end amplified America's image as a disinterested, objective arbiter by increasingly distancing their work, and the data it produced, from mediating cultural, political and racial categories left over from the Anglo-Saxon civilization framework Roosevelt had employed.

This revised American exceptionalism naturalized US history, and by extension a fascination with its state formation (rather than as part of some

\footnotetext{
${ }^{71}$ John Dewey, "Political Science as a Recluse," The Middle Works, Volume 11: 1918-1919, Ed. Jo Ann Boydston (Carbondale: Southern Illinois University Press, 1982), 94; “A New Social Science," The Middle Works, Volume 11: 87-92.

${ }^{72}$ Woodrow Wilson, "An Address to a Joint Session of Congress, January 8, 1918," PWW, 45: 538-539.
} 
Teutonic or Anglo-Saxon inheritance) as simultaneously the core America's exceptional identity, but also the core of a liberal internationalism that balanced the search for universalistic pricniples that would bind together the world. This argument is developed in three strands. First, I show how Shotwell, examined as part of the "New History" school, points to the emergence of a new rationality that balanced the universalism of liberal exceptionalism with the narrow and nationalistic concerns of American exceptionalism. I suggest that for the new historians the authority of modern knowledge about governance hinged on the assumption that social scientific knowledge had to be developed independently of the state and be insulated from the interests of society. From here, I next show how Shotwell's vision of exceptionalism was itself built on the idea that the proper liberal foundations of the state were best understood by social scientists in the US precisely because their work was not rooted to interests found in the economy, culture, race or religion as ossified in the structures of the state. Finally, I outline how this particular refashioning of American exceptionalism so that the preservation of its conditions stood at the core of liberal exceptionalism, and therefore any notion of a liberal international system, extended beyond Shotwell, fundamentally shaping who gained access to the social scientific institutions that emerged around the war and the subsequent peace process.

The New History In a Time of War: A Case Study of the Changing Character of American Exceptionalism 
Jim Shotwell's practice of history embodied a radically new social scientific foundation that treated American exceptionalism as synonymous with liberal internationalism. Nowhere is this more evident than in Shotwell's attempts to distance his work and institution-building from those American's who imagined the spread of liberalism as a joint Anglo-Saxonists civilizing project shared with England, a state now embroiled in what many in the US and across the world derided as an imperial war. A liberal segment of the American political and cultural elite certainly tried to influence America's entry into war on the side of Britain, emphasizing at every opportunity the connection between the defeat of Germany and the spread of shared liberal ideals. The influential historian and former AHA president George Burton Adams warned that "When England falls the doom of the United States is sounded. All our interests, those of language, commerce, civilization, and government, are common with her. History will declare that England holds no interest in this war that we have not held with her."73 Shotwell was not immune to the Anglophilia that characterized most academic social scientists in the US. His work with Adams in a secretive group of historians and educators demonstrates beyond a doubt that he believed historians had a role to play in convincing Americans that they "should enter the war to cast the balance

\footnotetext{
73 "Yale Men Assert American Rights: Call on President to Put Forth Full Power of Nation in Crisis," New York Times, March 10, 1917, 2.
} 
against Germany."74 And yet, even in that small committee, it was clear to Shotwell and the other members that there could appear no influence in favour of the English, lest the group be dismissed as "Anglo-maniacs." 75

A student of the Progressive or New Historians, Shotwell intellectually built on Frederick Jackson Tumer's earlier rejection of the Anglo-Saxon germ theory and its racialistic notions about the communication of liberalism through civic institutions and practices. Rather than seeing the US as locked into the same historical forces that seemed to throw European republics into cyclical decay and conflict, Turner had set out in the late 1890s to explain the "peculiarity of American institutions," driving at what made them seem uniquely stable. Turner concluded that "the distinguishing feature of American life" was its "continuous touch with the simplicity of primitive society" so that, unlike any other nation, the US was continually "breaking the bonds of custom, offering new experiences, and calling out new institutions and activities." 76 The constant renewal of America's national identity in the crucible of nature provided by the western frontier meant that America's nation identity-and the state form that followed from it-were exceptionally modern. Unlike the racial, class based, and sectarian identities that defined modern Europe's states and empires, America was vaunted as national

\footnotetext{
${ }^{74}$ James T. Shotwell, The Reminiscences of James T. Shotwell (1964): 65-67, in The Oral History Collection of Columbia University, cited in J. Michael Sproule, Propaganda and Democracy: The American Experience of Media and Mass Persuasion (New York: Cambridge University Press, 1997), 7.

${ }^{75}$ Mars and Minerva, 84. The members of this early group included, George Louis Beer, Shotwell, Dana C. Muro (all future Inquiry Members), Adams, Charles P. Howland and officers of the Rockefeller Foundation General Education Board.

${ }^{76}$ Frederick J. Turner, The Frontier in American History (New York: F. Ungar Pub. Co, 1966), 186-187; Ross, The Origins of American Social Science, 271.
} 
identity that, in so far as it formed around the shared goal of conquering the west, had developed governing institutions and practices that were effectively purged of any of those constituent identities that fought for control of the state and society in Europe.

The New Historians who emerged from Columbia between 1900 and 1914 took on this exceptionalist reading of America as a uniquely modern national. For James Harvey Robinson and Charles Beard, who found themselves on the van guard of what Novick has called a "genteel revolt" against Rankean methods in history, their methodological debates over the proper foundations of history as a social science had consequences that reached far beyond their discipline. ${ }^{77}$ For the New Historians who revolted against the Rankeanism, efforts to move beyond its narrowly hagiographic and political scope, and its preoccupation with oration and exhorting elites into heroic national leaders was about democratizing the focus of history by shifting its methods, forcing it away from the literary of canonical works. As early as 1896, Turner had told his student Becker that "the old union between history and literature is now broken in all the growing colleges." Literary historical methods were unfit for a modern, scientific age in which empirical findings could point to social realities a better reflected the general population rather than the visions and ambitions of individual great men. ${ }^{78}$

\footnotetext{
${ }^{77}$ Novick, That Noble Dream; Clyde W. Barrow, More than a Historian: The Political and Economic Thought of Charles A. Beard (New York: Transaction Publishers, 2000), 4-5.

${ }^{78}$ Ernst Breisach, American Progressive History: An Experiment in Modernization (Chicago: University of Chicago Press, 1993), 66-67.
} 
Importantly, however, the break with literary history that the New Historians pushed for was not a full break with Rankeanism. Beard and Robinson moved to anchor the authority of historical knowledge to the study of structures such as the economy, technology, science, religion, ideas and institutions. But, while this reimagined the sites of power that moved history along, they carried forward much of Ranke's understanding-which had also been influential on the thinking of the likes of Lieber, Burgess and Rooseveltof the world as progressing towards a unified international system. Of course, the emphasis on Teutonic or Anglo-Saxon institutions carrying forward the mantle of liberty were gone in much of the work of the New Historians. But this cohort still clung to the ideal that a totalizing or unified history was possible, emphasizing now the universal social, technological, political and economic forces that affected all societies. ${ }^{79}$ "All the remains that have come down to us," Turner argued, were to be examined, not just those documents of great men. ${ }^{80}$ History, Shotwell's adviser Robinson further argued in 1912, "includes every trace and vestige of everything man has done or thought since he first appeared on the earth." ${ }^{81}$

Shotwell's work and teaching points to this lingering interest in establishing a totalistic history. He attempted to explain how new history's interest in the social, technological, religious and economic spheres could all

\footnotetext{
${ }^{79}$ Novick, That Noble Dream, 6; G.B. Adams, English Constitution, 44-47. Also see Breisach, American Progressive History, 69-75.

${ }^{80}$ Frederick Jackson Turner, "The Significance of History," [1890] in Early Writings of Frederick Jackson Turner (Madison: University of Wisconsin Press, 1938), 8.

${ }^{81}$ J. H. Robinson, The New History, (New York, 1912), 2.
} 
drive towards a history of the "common man-his customs, thought, environment, and basic interests" that better explained, with greater scientific certainty, how civilizations developed around social forces that modern society needed to observe and manage, if one hoped to steer the course of progress. ${ }^{82}$ For Shotwell, like his New Historian mentors, history had a transformative capacity that brought "about progress in the field of knowledge." 83 The search for a more comprehensive and total knowledge, in an age when the very rationalities that underpinned the imperial state system of Europe seemed increasingly troubled, therefore demanded a history that rationalized the world not through the romantic lens of great actors and states, but through the scientific search for unifying social forces.

This shift in methodology, however, spurred a related change in the epistemology of social science itself, which carried far broader implications for the conception of liberal internationalism in the US. Faced with the move of economic and political scientific methods into history, the old professional guard in the AHA warned that there were consequences to allowing positivism to effectively colonize what had once been a discipline built around the ideal of the civic-minded citizen communicating the stories that mattered to a nation. In his 1909 speech to the $A H A$, then president George Adams

\footnotetext{
82 Josephson, Shotwell and Internationalism, 37.

${ }^{83}$ James Harvey Robinson, The New History, (New York: Macmillan Press, 1912); The Mind in the Making: The Relation of Intelligence to Social Reform (London: Jonathan Cape, 1921); The Humanizing of Knowledge, (New York: Arno Press, 1923).
} 
famously warned his fellow historian against using "ideals and methods not quite his own." 84

Robinson, one of the major targets of the speech, replied with a warning of his own, accusing the old guard of "boundless insolence and arrogance" in the face of the "far more reasonable pretensions of the modern social sciences." 85 With his usual zeal, Shotwell was markedly less kind, telling William Dodd in 1913: "it will not be long before we shall be able to ignore to some extent the pious old gentlemen who attempt to hold down orthodoxy in history. All we have to do is to turn our material and [the] world is ours." ${ }^{86}$ For the New Historians and Shotwell, aligning history with the social sciences and its use of statistical, ethnographic, geographical and observational methods elevated their history to the level of a science. While this allowed them to argue for the methodological merits of their New History, it also lent itself to the more political task of routing an old guard in both American history and society by undermining historical knowledge that situated American exceptionalism as the adherence to particular values and behaviours that were, increasingly recognizable as prejudicial and exclusionary .

To press back on this older school of history, Robinson, Beard, and Shotwell-to name only a few of the more notable converts social scientific

\footnotetext{
${ }^{84}$ Genrge Burton Adams, "History and the Philosophy of History," American Historical Review 14 (1909): 221-236.

${ }_{85}^{85}$ Novick, That Noble Dream, 91

${ }^{86}$ Ibid.
} 
history-portrayed America as exceptional for its relationship to nature; a relationship that assured the constant renewal of the nation and, by extension, checked against the ossification of specific interests in the state.$^{87}$ Turner had earlier hinted that "North America" uniquely possessed such an exceptional relationship, suggesting that the American nation-state and its social science inhabited "the most favorable field on the globe" from which to construct a "universal science of history." ${ }^{88}$ The New Historians built on this reading by arguing that the rigor of sociological, anthropological, geographical, statistical and economical methods problematized the connection between America's identity and Anglo-Saxonism, teutonism or liberal political economy as axiomatic elements of that identity. "It seems to me inevitable that just as the various sciences of nature were, before the opening of the seventeenth century, largely masses of rationalizations to suit the religious sentiments of the period, so the social sciences have continued even to our own day to be rationalizations of uncritically accepted beliefs and customs," Robinson argued in his The Mind in the Making. To avoid speaking for power, Robinson proposed that for historians to challenge "the whole problem of labour and capital," "national arrogance, race animosity, political corruption and inefficiency," they would have to develop an idea of "nature and workings of nations" that did not rely on the "rhetoric and appeals to vague fears, hopes of partisan animosity or mere partisan animosity," which marked

\footnotetext{
${ }^{87}$ Ross, Origins, 272

${ }^{88}$ Ibid., 273.
} 
the chavenistic histories of the past. "The scientists have been busy for a century in revolutionizing the practical relations of nations," and the enactment of these principles apart from the blind drive to "defend and perpetuate the conditions which produced the last disaster." 90

\section{Using Debates Over Internationalism to Modify American Exceptionalism}

The move to a "new history" that aimed to displace older historical rationalities may seem like a small change, but it hints at a larger shift in American's thinking about their nation-state and, by extension, the international sphere. By imagining that the proper governance of society and the state as best directed by experts outside of the prejudices and hierarchies of those sphere, the new historians bound on to a thread of positivism, evident-we have already seen-in the work of earlier American sociologists such as Ward. At the same time it also bound on to the ideal, also present in Ward and carried forward by works such as Throstein Veblen's Thoery of the Leisure Class, of a "sociocratic" or expert class that could pull social authority away from an opulent upper class through a more scientific management and understanding of the social world. ${ }^{91}$ Within a period that produced a rapid expansion of middle-class professional positions in the US, appeals to such

\footnotetext{
${ }^{89}$ Robinson, The Mind in the Making, 6-9.

${ }^{90}$ Ibid., 13. For a sweeping work on the role of the social sciences in history, and history's narrative mode see J. T. Shotwell, "The Interpretation of History," The American Historical Review 18 (1913): 692-709.

${ }^{91}$ Thorstein Veblen, The Theory of the Leisure Class (Toronto: Dover Publications, 1992), For an important discussion of Veblen see C. Wright Mills, The Power Elite (Toronto: Oxford University Press, 2000), 50-58.
} 
expertise resonated widely feeding on a growing desire to ameliorate some of the excesses and suffering of modern industrial capitalism. This helped prepare the way for a surge in the notion that professional expertise was best positioned to steer such reform, and to direct the governance of the state and society because, by offering a more scientific understanding of what social forces were at play, those that divided, and those that bound together, the nation. This larger shift in the thinking had dramatic effects on the foundations of knowledge used to rationalize America exceptionalism.

The worldview, which I have called civic internationalism, that dominated much of American's late nineteenth century thinking about the contours and practices that defined the international sphere, imagined America as exceptional for its historical inheritance of a civic virtue and political traditions (liberalism and republicanism) handed down from England. But such a view of exceptionalism proved increasingly difficult to sustain in the face of America's ever growing global role and a heterogeneous population that could not claim the mantle of Anglo-Saxonism but whom identified as American. Where internationalism was once a restrictive system limited to nations that could demonstrate civility by adopting these traits, the scientistic language of the new historians and their argument that American exceptionalism was defined by the ability to adapt as a nation to natural obstacles made internationalism a potentially, radically more inclusive system. 
But, in feeding on the deep republican distrust of knowledge and systems of social control centralized in the state or influenced by elite interests, and building on the liberal professional classes ideal of its own disinterested relationship the application of disinterested social science to the problem of how to govern without becoming too closely identified with the state presented its own tensions. This became especially apparent when social scientists ,like Shotwell, heeded the call to war. As he and other historians worked at the van guard of efforts to mobilize social scientists in late 1916 and early 1917, they reached out through still developing professional networks, such as the AEA, AHA and the American Political Science Association (APSA) to bring the new and productive statistical, mapmaking, economic and, in the case of historians, historical methods into service for the nation-state. Importantly these efforts met mixed reactions. The AEA upheld a constitutional provisions that prevented it from "going on the record in controverted matters," and never formally loaned support to the war effort. ${ }^{92}$ The APSA never formally endorsed mobilization but held a number of conferences and events meant to bring attention to and rationalize America's participation in the war. And the AHA, as we will see in more detail, was careful to remain unofficially involved in the war effort. And yet, though few professional associations would loan formal support to the state, one can easily find examples where economists, political scientists, historians and

\footnotetext{
${ }^{92}$ Gruber, Mars and Minerva, 8, 121.
} 
anthropolgists laboured away inside wartime agencies and departments and loaned professional resources to those apparatuses.

This contradiction is perhaps most apparent if we look at the American Economics Association. By 1917, that organization still bore the scars of its Gilded Age conflict between socialist and classical economists when changes to the Association's constitution made nearly impossible any official partisan stance. But that did not stop many economists from trying to work for the state or trying to steer policy from. For example, Richard T. Ely, once a giant of the AEA, the first of the generation of German-trained ethical economists who had challenged the orthodoxy of laissez-faire liberal economics, and a teacher to an impressive roster of students (including J. Franklin Jameson, Turner, and even Woodrow Wilson) attempted to join in the war effort. Throughout the closing decades of the $19^{\text {th }}$ century, Ely had done more than perhaps any other academic in the US to spread the notion of the state was acting as "the greatest redemptive force in society," and argued that government was a God-given "instrument through which we had to work." 93 Ely had been a strong progressive follower of Roosevelt before the war, and with America's entry into the War, became a vociferou advocate for the mobilization of professional social scientific resources. Like so many of his elder cohort of social scientists, Ely framed the call to war as a stark battle between

\footnotetext{
${ }^{93}$ Cited in Murray N. Rothbard, "Richard T. Ely: Paladin of the Welfare-Warfare State," The Independent Review 5 (2002): 585-589.
} 
"autocracy and civilization,.." ${ }^{94}$ But in criticizing the influence of the state over the German professoriate Ely reiterated the ideal of Anglo-Saxon nations as uniquely equipped to avoid the pitfalls of autocracy. Ely's calls for America and Britain to "get closer together" so as to create "an intellectual and spiritual empire," were anchored firmly to racialistic language $o^{95} \mathrm{D}$

Feeling "left out of the war work which has been going on in Washington," Ely set about attacking disloyalty at home, in Wisconsin. There he attacked a former progressive stalwart and ally, Senator Robert M. La Follette and took the extremely controversial step of calling for the total suspension of academic freedom during the war. While he received a remarkable amount of support from colleagues, he considered opposition treasonous and proclaimed that professors "who hinder us in this awful struggle," should be "shot." In his efforts to build a case against La Follette, Ely turned to a former colleague, Dana C. Munro, in a fledgling group called the National Board for Historical Service (NBHS), asking him to gather whatever that group came across in their work translating Austrian and German papers that might show the "encouragement (La Follette) has given Germany." "Munro, also member of the controversial Committee for Public Information (CPI), received Ely's request and with great caution quickly handed it over to the CPI where Ely received tempered cooperation but was

\footnotetext{
${ }^{94}$ Benjamin G. Radar, The Academic Mind and Reform: The Influence of Richard T. Ely in American Life (Lexington, Kentucky: University of Kentucky Press, 1966). Cited in David L. Herzberg, "Thinking Through War: The Social Thought of Richard T. Ely, John R. Commons and Edward A. Ross During the First World War," Journal of the History of the Behavioral Sciences 37 (2001): 129.

${ }_{95}^{95}$ Gruber, Mars and Minerva, 128.

${ }^{96}$ Cited in Rothbard, "Richard T. Ely: Paladin of the Welfare-Warfare State," 588.
} 
never made aware of much of the social scientific work being done by the Wilson Administration. Ely's attempts at smearing La Follette, in which he was joined by a substantial portion of the Wisconsin faculty, proved ultimately unsuccessful. But when considered as symptomatic of a shifting rationality of American exceptionalism its illustrates how social scientists were developing new ways of articulating nationalism and internationalism very much like those expressed by the New Historians.

In this light, it is interesting to note that even those given access to the various bureaus or departmental projects around moilzation and peace panning often complained of the control exerted by a particular group of social scientists, which included some of the New Historians. Like many of his colleagues at Wisconsin, Munro voiced concerns that his professional circles in the mid-west were being marginalized and given limited access to the various social scientific bodies that were cropping up around the war effort. His colleague, a classical historian (and future Inquiry member) William Westermann focused his displeasure squarely on what he saw as the prominent role played by the New Historians in the fledgling NBHS. The Historian Carl Russell Fish reported that many of his colleagues were "afraid that the 'Robinson-Columbia' school of history has run us off our feet," A sentiment Westermann echoed when he acerbically accused the Board of playing into the "the hands of the pseudo-historians of the ultra modern 
tendency." While their differences took the form of methodological and epistemological divisions, Westermann and the Wisconsin schools' feelings of marginalization were gradually placated by Shotwell, who endorsed Westermann and Munro. ${ }^{98}$

The formative effect of this new exceptionalism is particularly pronounced in the story of Shotwell's recruitment of another former Wisconsin faculty member, Allyn A. Young. Although Young had trained under Ely, his work seemed much more sympathetic to a modified exceptionalism that thrust American liberalism to the center of understanding modernity across the world. After the war, Young quoted Turner's belief that "Statesmanship in this nation consists not only in representing the special interests of the leader's own section, but in finding a formula that will bring the different regions together in common policy." Young, who saw the nation as "itself a section," had little regard for what he considered the sectionalist interests and motivations of political statesman. He thought they merely played the roles "assigned to [them] in popular dramatization of the facts of international economic intercourse." 99

Young's sharp distrust of political and elite interests as parochial would only sharpen once he became involved in the Inquiry and further refined when he traveled to the Paris Peace Talks. There he was among the key

\footnotetext{
${ }^{97}$ Novick, That Noble Dream, 121.

${ }^{98}$ Westermann and Munro would become integral to the Inquiry's Middle East Division and would actually travel with Wilson to Paris in 1919.

${ }^{99}$ Allan A. Young, "Economics and War: A Presidential Address," The American Economic Review 16, (1926), 1-13.
} 
signees of the letter of dissent during the crisis over Fiume, which argued Italy was being dangerously and narrowly nationalistic in demanding control of the territory. ${ }^{100}$ However, Young's faith in social scientific knowledge to guide governace was evident well before he joined the Inquiry. As early as 1905, the statistician questioned Roosevelt's empirical basis for his controversial notions of race-suicide, and by 1917 had been chosen to sit as the president of the American Statistical Association. ${ }^{101}$ In his 1918 presidential speech, Young argued for a larger use of statistical tools arriving at a "degree of self-knowledge far beyond anything that we might have imagined necessary or possible in the past." 102 Thus, Young endorsed the notion that social science was integral to the management of disinterested policies that were as applicable in the international sphere as they were in the national. Gone was any overt articulation of the US as part of a historical and racially defined march of liberty, replaced with a rigorous if at times overwhelming attention to statistical data as more accurately representative of societies.. ${ }^{103}$

But to say that social scientists endorsed a scientific study of societies and avoided controversy by steering clear of older articulations of excpetionalism is not to propose that these circles had somehow removed

\footnotetext{
${ }^{100}$ Charles P. Blitch, "Allyn A. Young: A Curious Case of Professional Neglect," History of Political Economy 15 (1983): 10.

101 Allan A. Young, "The Birth Rate in New Hamshire," Publications of the American Statistical Association 71 (1905): 263.

${ }^{102}$ Allan A. Young, "National Statistics in War and Peace," Publications of the American Statistical Association 121 (1918): 873-885.

${ }^{103}$ Not insignificantly, by 1925 Young would draw extensively on the work of Dewey, James and the American Prgamatists. See notably Allan A. Young, “Economics and War: A Presidential Address," 4-6.
} 
racism, sexism and classism from their world view. George Beer is perhaps the best example of this. An unabashed member of the Republican Party, Beer was both a trained historian and an independently wealthy broker from New York who had taught at Columbia until 1897. When he was brought into the Inquiry, its executive members were warned of his Anglophilia. ${ }^{104}$

But by 1917, with his publication of The English Speaking People, Beer's tune changed. Rather than focusing on the Anglo-Saxons as a culturally "kindred peoples" whose "similarity was obscured by superficial ... economic and social conditions," Beer also focused on how new institutions could facilitate an international order that would "permanently unite in a common co-operative purpose different nations and at the same time allow free play to distinct, but not discordant, loyalties of great intensity." ${ }^{105}$ Beer proposed that American liberty and its institutions had avoided the pitfalls of those nationalisms and states that had "Hide-bound" populations to "traditions of the sovereign state demanding from its citizens' supreme and undivided dedication." "American political thought," Beer argued, was distinct because "unlike that of Germany, [it] does not make the organization an end in itself, to which the individual must be completely subordinated, and

\footnotetext{
${ }^{104}$ There was no secret in this. Beer had published in The Political Quarterly, The New Republic, The Forum, and elsewhere on the close allegiance between England and the US. Furthermore, as one of the major figures in the "imperial" history school, Beer had tried to argue that the American Revolution had happened despite a fair place within the British Colonial, mercantile system of the dayNovick, That Noble Dream, 82. Anthony Brundage and Richard Cosgrove, The Great Tradition: Constitutional History and National Identity in Britain and the United States, 1870-1960 (Stanford: Stanford University Press, 2007), $139-148,164$.

${ }^{105}$ George Louis Beer, The English Speaking People: Their Future Relations and Joint International Obligations (New York: Macmillan Press, 1917), xi. 69.
} 
whose aim must inevitably be the quest of power." 106 The formulation of a new form of internationalism, and the move away from a attempts to drive the two great Anglo-Saxon nations to the fore of international order, while "advisable," could not be done in a way that built the power of the sovereign state so that attempts at a "new type of permanent political association" were crushed by the interests of the state. Gone was the idea of an imperial state pressing outward the virtues of Anglo-Saxonism. Instead, Beer imagined American and British cooperation beyond the state as both a defense of their "own civilization" while also forming the bedrock of support of the ideal of "liberty of all threatened by the sword of those who worship at the shrine of organized power."107

Beer's ideas on the foundations of international order were ambiguous. ${ }^{108}$ On the one hand they were very much rooted in a belief in the cultural and institutional superiority of the Allied democracies, especially that shared by the British and Americans. And yet, on the other hand, Beer

\footnotetext{
${ }^{106}$ Ibid., 71.

${ }^{107}$ Ibid., 271.
}

${ }^{108}$ Beer, like Shotwell, was closely involved in secretive pro-British propaganda in the lead up to American intervention and as the head of the Inquiry's research on the world's "Colonial Problems," a position he continued to hold in Paris, his Anglophilia and belief in the benevolence of the British, rather than the German colonial model, was rarely questioned and tacitly accepted by the other Inquiry members. But consent about British colonial interests was also the product of a lack of interest in the German Colonies, which in 1919 Wilson called "not vital to the life of the world in any respect," an endemic fear among white Americans of black Africans, and a belief that Northern and Sub-Saharan Africans were backwards nations incapable of self-government."These small nations with intense national feelings," Beer wrote to himself of Belgian colonial aspirations, "bore me." He felt alienated by the "academic nature" of Wilson's ideas on self-determination, noting to himself the not uncommon view that, "Wilson is strong on principles a sophomore might enunciate, but is absurdly weak on their application." For more on Beer in the Inquiry see Smith, American Empire, 172-176. For his thoughts on the Fiume controversy see G.L. Beer, Diary, 17 May 1919, PWW, 59: 244-245; For his influence on the methods used in the Inquiry and their concepts of colonialism see Jeremy Crampton, "The Cartographic Calculation of Space: Race Mapping and the Balkans at the Paris Peace Conference of 1919," Social and Cultural Geography 7 (2006): 747. 
balanced this with the idea that he was a "representative of the New World at grips with the legacy of the Old World's Problems." ${ }^{109}$ Beer situated the US within a larger teleological march towards a cosmopolitan world built on a particularly American model. He had little patience for the institutions of internationalism that had thus far formed, particularly those juridical ones such as the Hague, which had been allowed to grow out of a narrow conception of sovereignty and jurisdiction, and which conflated the interests of malleable, and shifting national identities with the container provided by the state. "The stern obstacle to the political organization of the world," Beer proposed, "is the sovereignty of the state," which assumed "the absolute independence of the state" and "its isolation in an anarchic world of equally independent politico-legal units." 110 While Beer acknowledged the force of these existing institutions and the juridical regime around them, he was no statist nor a nationalist. Rather, Beer proposed that international institutions that upheld the sovereignty of distinct nation-states were merely institutional "intervals" on the way "between a world state and the existing system of sovereign nations." 111

Beer's is a model of how the belief in the moral and cultural authority of the English-speaking people as a nation was fitted to an emergent exceptionalism that had been stripped of any dependence on state

${ }^{109}$ Cited in Roger Louis, "The United States and the African Peace Settlement of 1919: The Pilgrimage of George Louis Beer," The Journal of African History 2, no. 3 (1963), 417.

${ }^{110}$ Beer, The English Speaking People, 79.

${ }^{111}$ Ibid., 16-18. 
imperialism, but which was still deeply rooted to racialist ideas of the virtues of America as a model for the world. This new exceptionalism treated America as a model of nationalism wherein the state was defined and redefined by constantly progressing social solidarities and political institutions that reflected these social realities. There was little in the way of a substantial shift in American intellectuals' sympathy and affinity towards Britain. Rather, the concept of America's historic connection to Britain had shifted, so that the social practices that had allowed the American nation-state to develop as a supposed alternative to the European model now represented a new universal model where the nation-state was taken as an organizational unit needed to facilitate rather than restrict the spread of liberty. Haskins was not alone in "English history," Charles Haskins wrote immediately following the war, "is in a sense, early American history." But, as he would later emphasize, "with the passing of the war Europe and America are now in the same boat, along with the still older Orient, all common material for history. The historian's world is one; let him interpret it as one, in relation to both scholarship and to the molding of public opinion!" "112 For the cohort of social and historical scientists that emerged in the war generation, drawing attention to the discontinuity between American liberal institutions and those of England and Europe was an effective way to simultaneously feed American exceptionalism and elevate

\footnotetext{
${ }^{112}$ Charles Haskins, "European History and American Scholarship," The American Historical Review 28
} (1923): 215. 
American social science to the core of the coming cosmopolitan polity that was a "moral, not a legal obligation."113

This was an important innovation. Epistemologically, it brought the story and study of America more firmly to the center of a grander, modern search for universal foundations for knowledge, carrying the world past what Franklin Jameson called, in 1912, "the Age of Nations", and into "a new world which will be marked by cosmopolitan thought and sentiment." The war was critical to this epistemological repositioning. ${ }^{114}$ Thus, the strength of this new American exceptionalism was not that it provided Americans with a vision of their present system of constitutionalism as a political utopia to be passed into the world. ${ }^{115}$

Even Wilson had earlier proposed that a "constitutional" stage was merely a step in a larger development. While the Constitution united the nation, its interpretation was "no longer regarded as of pressing urgency," leaving the US to the "unexciting but none the less capitally important business of everyday peaceful development" through "judicious administration." "Surely," Wilson opined in 1885, "there must be a cause to be advanced that is greater than the trammels of governmental forms." The

\footnotetext{
113 John Milton Cooper, Woodrow Wilson: A Biography (Random House Digital, Inc., 2011), 515; For one of the first and defining works to seize on Wilson's distinction between moralistic and legalistic obligations see, Denna Frank Fleming, The United States and the League of Nations, 1918-1920 (New York: G.P. Putnam, 1932), 312-314.

114 Ian Tyrell, "American Exceptionalism in an Age of International History," The American Historical Review 96 (1991): 1035.

115 Hardt and Negri, Empire, 176.

${ }^{116}$ Stephen Wertheim, "The Wilsonian Chimera: Why Debating Wilson's Vision Hasn't saved American Foreign Relations," White House Studies 10 (2011): 345.
} 
First World War presented an opportunity to break free of these trammels by developing an American exceptionalism that was no longer rooted in immediate concerns and governmental forms, but rather to a more advanced cause of establishing a truly modern knowledge, built on the perpetual renewal of individuals and institutions until then unique to America.

Of course, this meant that the institutions and associations that American social scientists participated in could not be seen as beholden to the same historical-political forces that had ossified liberalism in many European states. Though the French and British were comfortable with the state visibly guiding social scientists in state offices or agencies on peace preparations, American social scientists during and after the war developed different institutional relations to influence state formation around their conception of its nature. For many European social scientists, there was an understanding that they, as experts, had the capacity to measure, delimit and define self-determination. But for them, work on self-determination needed to be weighed against the interests of the state as articulated in what Wilson and many Americans considered the outmoded language of raison d'état or the balance-of-power. The commitment of many European social scientists to a scientifically-guided world of self-determined nations seemed to many Americans to be either half-hearted or insincere for this very reason. ${ }^{117}$

\footnotetext{
${ }^{117}$ Frank Ninkovich, The Wilsonian Century: U.S. Foreign Policy Since 1900 (Chicago: University of Chicago Press, 2001), 24-25.
} 


\section{Keeping Up Appearances: The National Board for Historical Services and Institutional Distance}

Upholding this particular liberal state effect demanded that the new social scientists maintain the appearance of a distance between themselves and their work, on the one hand, and the interests they represented as essential to the form of states and societies. This meant, in turn, marginalizing those other social scientists whose objectivity was undermined by their failure to adapt to the new models of society. But, it also meant strategically and deliberately obscuring perceived connections between their work and the state as they set out to acquire power through the pretensions of an objectivity that was the sine qua non of the new social legitimacy.

Among the corps of social scientists that rushed to meet the call of war, professional historians could most assuredly be considered its vanguard. Of all the academic guilds in the US, the American Historical Association (AHA) was the oldest, strongest and, not coincidentally, most closely connected to the state through its institutions and leadership. But, as Marcus Gräser has noted, and as I have already touched on, "a new generation of progressive historians who claimed to write a 'new history' succeeded in modernizing historical writing in America," ${ }^{118}$ and in doing so, interrupted the often seamless flow between America's genteel professional culture and the government. Turner, the Beards, Jameson, Shotwell and Robinson built an alliance with the social sciences, expanded the topics and objects of

\footnotetext{
${ }^{118}$ Marcus Gräser, "World History in a Nation-State: The Transnational Disposition in Historical Writing in the United States," The Journal of American History 95 (2009): 1048.
} 
investigation beyond classic political history, and reoriented the focus of history toward the present in such a way that they were convinced the synchronic and diachronic forces of the social world could no longer be explained by reference to the nation-state alone. As Jameson argued in 1912, the "nation is ceasing to be the leading form of the world's structure; organizations transcending national boundaries are becoming more and more numerous and effective .... We are advancing into a new world which will be marked by cosmopolitan thought and sentiment."119

Yet despite the confidence in some quarters that the world was entering into a more cosmopolitan age, America's foray into world war presented many of these social scientific historians with a palpable opportunity to rethink the rationalization of the state in an academic capacity. Moreover, it invited them to become directly involved in the conduct of this new governmentality. Having already crossed the ideological divide in worldviews between the Rooseveltian character and Wilsonian intellect, key figures in the AHA once again rallied to legitimate the American state. But this time, they did not rely on their professional association directly. Instead, they cultivated a social science-state nexus that consolidated their role as experts analyzing the social world and gathering data apart from or outside the official mechanisms of the state. As the association's then serving Secretary, Waldo J. Leland, would later argue, before "the First World War, the function of the

\footnotetext{
119 J. Franklin Jameson, "The Future Uses of History," (1912) in Ed., Morey Rothberg, Selected Essays
} (Athens: University of Georgia Press, 1993). 
archivist and historian was to record and interpret after the event." But after war broke out, he continued, "The importance of the historian as an agent of causation came slowly to be recognized," and historians came to see themselves as "having obligations to the common cause."120 But they had to be sensitive to who was seen steering this common cause.

The mobilization of historians and archivists was at first quite public, and the purpose of their work openly debated and scrutinized by those inside and outside the Association. On April 29, 1917, Franklin J. Jameson, among the most significant figures in the professionalization of history in the US, called together seventeen historians to "consider the problem of what they and their fellows can do for the country in time of war." He was then the head of the Department of Historical Research of the Carnegie Institute of Washington, and the managing editor for the AHA's main publication, American Historical Review, which enabled him to work with some of the most influential historians of the time to, in his view, provide historians "with a better chance to make history serve the nation, by making historical scholarship available for educational and patriotic ends." ${ }^{121}$ Along with Frederick Jackson Turner, Frederic Paxson, Andrew McLaughlin, Leland, Guy Stanton Ford and future Inquiry members including William Dodd and Shotwell, Jameson oversaw the establishment of the National Board for Historical Service (NBHS), to "bring

\footnotetext{
${ }^{120}$ Waldo G. Leland, "Historians and Archivists in the First World War," The American Archivist 5 (1942): 2.

${ }^{121}$ For this and more on the correspondence of the NBHS see, William T. Hutchinson, "The American Historian in Wartime," The Mississippi Valley Historical Review 29, (1942): 167-169.
} 
into useful operation, in the present emergency, the intelligence and skill of the historical workers of the country."122

Though keen to serve their nation and state, the historians of the NBHS were careful to clarify that the board did not speak for the AHA, which took no official position on the war. Cornell professor Charles H. Hull argued to the meeting of the Board that, "as patriotic citizens, and also as history men," they had a duty to offer their services to the state and its goals, and yet as scholars "must not make democracy secure from autocratic and militaristic aggression abroad by methods which may deprive us of all that made democracy desirable at home."123 To pre-empt any argument that the movement of American historians towards explicit service to the state was tantamount to the academic-state nexus of Prussia, Hull and the other NBHS founding members assured the larger professional community that the altruism of America's stated foreign policy goals made working for their state less compromising; the US and its experts were, after all, not interested in territorial conquest, but in sharing the seas and making the world safe for democracy. And if any doubt lingered that the resources of the AHA were being brought under the control of the state, the NBHS's initial statement of purpose to 150 historians across the country-who were almost all members of the AHA - was clear that the Board was "a voluntary and unofficial organization of individuals

\footnotetext{
${ }^{122}$ Josephson, Shotwell and the Rise of Internationalism, 51; Gruber, Mars and Minerva, 120. Not insignificantly, Archibald Carry Coolidge, a core member of the Inquiry and member of the delegation to negotiate peace in Paris also later joined the NBHS as a core member.

${ }^{123}$ Charles H. Hull, "Remarks on the War and the Historians Role in it," 27 April 1917 (box 25), National Board for Historical Services Records, Library of Congress Manuscripts Division. (Hereafter NBHS Papers)
} 
spontaneously formed in the hope that through it the store of competence and patriotic good will possessed by the history men of this country ... may eventually be drawn upon to meet the needs of the public or government."124 While key members of the AHA, especially those who overlapped with the NBHS, encouraged professional publications and conferences to focus on the war, the division between the professional association and the newly formed NBHS was emphasized in professional circles, which understood the importance of a distance between the profession and its voluntary liaison with the state.

The NBHS was meant to create a network that would serve as a buffer between the state and the professional historical and social scientific groups that wished to appear entirely apart from political wrangling. But the actual distance between agents working for the state and key members of the AHA was far more ambiguous than many were comfortable with. Haunted by the specter of the letter from the German intellectuals, the fear was that the Board exposed the profession to the broader accusations of the same. By 1917, news of the arrest of dissenting historians in Belgium and the German manifesto of October 1914 seemed to reveal, for American academics, that it was necessary to differentiate their cooperation with the state and championing of nationalism from the "subordination of German scholarship to the dictates of

\footnotetext{
124 "The American Historical Association, Annual Report: 1919" The American Historical Review 24 (1919): 349-357; also see Leland, "Historians and Archivists in the First World War," 4.
} 
policy" that were widely attacked as a characteristic of Prussian militarism. ${ }^{125}$ Before America entered the war, its historians were clearly disappointed by the collapsing boundary between the professional class and the state, not only in Germany, but across Europe. As one Dartmouth professor of history noted in 1916,

On both sides and in neutral countries, there has been such a conspicuous failure on the part of historians to show any considerable exemption from the passions of the hour that one may conclude...that historians have been claiming for history, pursued according to a scientific method, much more finality than is warranted. In this matter the historian seems to have sinned along with the other social scientists, the economists, political scientists, and sociologists. ${ }^{126}$

With America's entry into war, however, suddenly most of these reservations seemed to melt away, replaced by, at best, a certain ambivalence between wanting to aid the war effort and wishing to maintain a professional distance from the interests and policy of the state. The NBHS was given office space by the AHR in the Carnegie Institution Building in D.C., and Waldo Leland, secretary of the AHA, also served as secretary of the NBHS. The principal outlet for NBHS materials was The History Teacher Magazine, whose financing came from the AHA, and whose masthead after June 1918 carried the words "Edited in Cooperation with the National Board for Historical Services and under the Supervision of a Committee of the American Historical Association." Still, it was repeatedly emphasized that the AHA had nothing to do with the

\footnotetext{
${ }^{125}$ Stuart Wallace, War and the Image of Germany: British Academics, 1914-1918 (Edinburgh: John Donald publishers Ltd., 1988), 33.

${ }^{126}$ F.M. Anderson, "The World War and the Historians," History Teacher Magazine, 7(1916): 329.
} 
Board and its propagandist work. As Shotwell argued when he announced the formation of the board in June of 1917, in History Teacher Magazine, the board was a way for historians to "serve the country ... as historians."

Building on his reputation for the work he had done mobilizing historians to seed opinion columns throughout the state, Shotwell was chosen as the first chairman of the NBHS. The Columbia historian set immediately to work tightening connections with the CPI, with which he worked in honing the program for the board. George Creel, the CPI's head, quickly appointed Shotwell an adviser on historical matters and helped create a new Division of Civic and Educational Cooperation that would aid the NBHS in reaching out to networks of teachers, educational institutions and government offices throughout the US. The actual purpose of the NBHS reaching extensive civic and governmental ties was unclear. Initially the group planned to focus on teaching and public education, to offer prizes to high school and elementary teachers, to give lectures at YMCA and training camps that were springing up across the country, and to direct the work of young scholars already in the universities towards the "problems which will be the pivot of politics and legislation during their lives." ${ }^{28}$ But the board also understood that it could "aid, encourage and organize state, and regional, and local committees, as

\footnotetext{
${ }^{127}$ James T. Shotwell, "The National Board for Historical Services," History Teacher Magazine 8 (1917): 199-200.

${ }^{128}$ Hutchinson, "The American Historian in Wartime," 168; Leland, "Historians and Archivists," 6.
} 
well as special committees ... to cooperate with other agencies and organizations, especially in the general field of social studies." 129

Few historians voiced concern over the prospects of their craft being mustered so directly for the purposes of the nation, and in the cause of war. Shotwell seemed especially comfortable with a tight intertwining of historical work and the state, and was disappointed that the NBHS was not more structurally connected to the state where it could offer a new "constructive statesmanship." ${ }^{130}$ So the chairman moved his organization closer to the CPI by offering the German language skills of historians associated with the board, who could then be used as part of an extensive newspaper and literature monitoring program tracking the content and problematic works in American-German and international publications. And yet, despite bringing the NBHS closer to government where it was by any interpretation directly serving the administration, Shotwell and other historians believed that they were playing safe, heeding the warning against making "the sacrifice that no historian must make. He must not distort or pervert the facts of history to suit the present struggle."131

A few historians remained skeptical of the NBHS's ability to work with the American state and not feed American hyper-nationalism or statism in the process. For example, when asked to develop a curriculum for history

\footnotetext{
129 "Resolution adopted at Washington for the establishment of a National Board for Historical Services," 29 April, 1917 (doc 034), NBHS Documents.

${ }^{130}$ Josephson, Shotwell the Rise of Internationalism, 124.

${ }^{131}$ Novick, That Noble Dream, 123.
} 
teachers in primary and high schools across the nation, the Columbia Teacher's College professor J. Montgomery Gambrill argued that "the legitimate demands of nationality must be everywhere satisfied," but, he insisted, "there would remain the larger problem of reconciling nationalism with internationalism; of providing military and economic security, equality of opportunity in the world's markets and in the development of backward and undeveloped countries." For Gambrill, any historical treatment of nationalism quickly revealed just how tightly those forces were pressed into the service of imperialism, and in this the US was no exception. Gambrill argued in the overview of his syllabi for the NBHS that it was incumbent on historians to teach students to question the positive values of nationalism, which depended on enmity alone to motivate citizens to action. The NBHS was uncomfortable with Gambrill's final product, and argued that "the comparatively untrained teacher" would likely fail to see the war as an elemental clash between autocracy and liberal democracy without that tension clearly articulated as the purpose of teaching. ${ }^{132}$ Rather than allowing teachers to focus on the negative attributes of nationalism regardless of the political culture of particular nations, the NBHS commissioned a new syllabus that indicted the Central Powers alone, and emphasized pan-Germanism as the root of the war. As one historian complained of the revised syllabus: by drawing up an indictment

\footnotetext{
${ }^{132}$ Lewis Paul Todd, "Wartime Relations of the Federal Government and the Public Schools, 1917-1918," American Education: Its Men, Ideas and Institutions, (New York: Arno Press, 1971), 55-56.
} 
rather than a balanced historical interpretation, "we are dealing with the historian turned propagandist." 133

Concerns about working closely with the CPI, an independent agency of the government, also attracted scrutiny from liberal-internationalists outside the professoriate. On June 8, 1918, The Nation published an article attacking the censorship and embargo on German newspapers coming into the US, noting that the work of the Historical Research division of the NBHS was aiding in censorship goals laid out by the CPI. Though the article did not explicitly connect the NBHS to J. Franklin Jameson, who worked as both the head of the Carnegie Institute's Historical Research Department and as Editor of the American Historical Review, Jameson quickly wrote The Nation to defend the NBHS and his own institutions' role in censuring German publications. Jameson demanded that The Nation retract allegations that the "historians and economists" of the NBHS were facilitating the concentration of periodical content in the hands of the government, and noted that the NBHS, funded by the Carnegie Institute, collected materials that were readily available to "writers and students doing serious work."134 The Nation did not print a retraction but no further controversy came from this article.

The Nation's dogged interest in the NBHS did, however, stick with Shotwell and the increasingly formal state-social scientific nexus in the US. In July 1917, Shotwell resigned from the NBHS because of illness and distanced

${ }^{133}$ Gruber, Mars and Minerva, 132.

134 J. F. Jameson, "Letter to Editor," The Nation, 10 June, 1918. 
himself from it in title, handing the reins over to Everts B. Greene. Shotwell was quickly recruited by House for the Inquiry, where he made it clear in official and private correspondence that the resources of the NBHS and, by extension, the network of institutions and organizations he helped develop were at the disposal of the Inquiry. By 1918, Shotwell was plumbing these networks for cooperation and resources, playing up the importance of this latest organization to the professional reputations of historians in the US. For example, in a letter to Jameson in January he argued that if "American historical scholarship is to make good in one of the severest and most important tests to which it has been submitted, the Research Committee of the History Board," explicitly organized to "cooperate and assist with the Inquiry," must "be supplied with the services of at least two research associates who could work in close touch with the Inquiry at all times." ${ }^{135}$ His appeals resonated with Jameson, who used his considerable access to financing, professional resources and graduate students to focus historical attention on the war, which he believed proved the professional historian more valuable than ever.

Despite building tight institutional relations with state agencies like the CPI and State Department, and with the knowledge that placing professional institutional resources at the service of the state would mean unprecedented

\footnotetext{
${ }^{135}$ Shotwell to Jameson, 7 January 1918 (box 12) John Franklin Jameson Papers, Library of Congress Manuscripts Division. (Hereafter refered to as Jameson Papers) For discussions of efforts to use graduates student thesis to gather information for the NBHS and Inquiry see "Inquiry minutes of Aug. 2, 1918 meeting," Shotwell Papers (Box 13), For published information on formation of NBHS and its connection with Shotwell see Josephson, Shotwell and the Rise of Internationalism, 55.
} 
influence over state policy, these same players understood that the appearance of distance between the state and social scientific institutions was what made the historians and other social scientists so relevant to the state. Against the backdrop of this delicate balancing act, then, we can make begin to make sense of Shotwell, Greene, and Mezes's very worried reaction to news in July 1918 that a connection between the NBHS and the Inquiry had been leaked to The Nation.

There had been little doubt among those in both organizations about the desirability of their connection, and a relationship was formalized at an earlier meeting of the NBHS in November 1917. As Gelfand has uncovered elsewhere, discussions led to the formation of "an advisory committee" consisting of Frederick J. Turner, William Dodd, and William Dunning, among others. Shotwell was adamant that "publicity be avoided" and, as my own archival work has uncovered, he was careful to both obscure his work for the Inquiry and to hide coordination between it, the NBHS, the Carnegie Group and AHA, even using letterhead from the NBHS to conduct Inquiry business. ${ }^{136}$ While Shotwell joked that it was "a harmless bit of camouflage," he still demanded secrecy around the connection between the NBHS and the Inquiry be taken very seriously. So much so that when Everts Greene received word that The Nation planned to write of the connection between the two bodies in July 1918, he quickly wrote to Shotwell and Mezes to apologize for being the

\footnotetext{
${ }^{136}$ Gelfand, The Inquiry, 45; Also see Shotwell to Dodd, "Meeting Minutes of NBHS," 3 December, 1917 , Dodd Papers.
} 
source of the leak. The connection was never formally outed by The Nation, and Mezes assured Greene that any reports "won't do much harm," though "it would have been better to have no published statement." ${ }^{137}$ The connection between the AHA, Carnegie Institute, NBHS, State Department, and Committee on Public Information reveals a relationship between state and non-state organizations that was left intentionally ambiguous, and wherein traditional non-state players seemed to understand that access to the state could play a powerful role in legitimating particular methods, over and above others, by vaunting them as the foundations of disinterested state policy. Yet they vehemently denied any such connection.

\section{State Effects}

The story of Shotwell and the development of the NBHS is an instructive one. Historical examinations of the Society have mostly focused on the propagandistic nature of the work, treating it as a lapse in professional judgment. ${ }^{138}$ Perhaps the most scathing indictment along these lines was Novick's argument that the NBHS experience provided "lessons about what a weak reed professionalism was in checking excess. In fulfilling their propaganda tasks the wartime historians were almost always scrupulous about maintaining the formal norms of scholarship," such as the rules of source criticism, careful annotation, extensive sourcing and accurate translations. Methodological standards and conceptual norms that many saw

\footnotetext{
${ }^{137}$ Greene to Mezes, 21 July 1918, Mezes Papers .

${ }^{138}$ See for example Gruber, "The Historians Cut Loose," Mars and Minerva.
} 
as bulwarks against politicization proved surprisingly malleable and did little to protect professional historians from the intoxicating allure of the power that came with cooperating with the state..$^{139}$

Building on these points, the construction of institutional relations between para-governmental groups, professional associations, and state institutions, while at the same time trying to conceal these networks, highlights a lesson about how American social scientists balanced the tension between their identities as citizens in an exceptionalist state. The social scientists who pushed social scientific work into state policy clearly understood that by naturalizing American exceptionalism as the core of a new rationalization of internationalism, they could fuel the notion that the US was a politically disinterested and morally magnanimous power, while also garnering a special place for their work in directing its course. All they had to do was provide knowledge that was apparently divorced, in theory and institutional practice, from the bald interests of the state. As the next chapter shows more deeply, some in the Inquiry continued to play up their own exceptional non-state authority on internationalism in the US and around the world, even while they acted as agents of a nation deeply animated by the patriotic emotions of war.

\footnotetext{
${ }^{139}$ Novick, That Noble Dream, 127.
} 


\section{Chaptex Five:}

The Inquiry and The Non-State International Expert

I wish I were a Science, or an Ethics, or

a plan

Or anything instead of 'just an ordinary man

If I were but a doctrine, mine would be a gayer lot

Or I should be delighted were I just a Higher Thought-

For then the men of millions would be handing out the checks

To aid in saving me from all the hinderances that vex.

--Wilbur D. Nesbit, Chicago Tribune, $1917 .^{1}$

On a cold December day in 1918, three US Army trucks arrived at pier number four, Hoboken port, New Jersey. The trucks carried thousands of boxes of raw data, reports, maps, books and atlases gathered from libraries across the US. The impressive cargo had been accumulated, over nearly two years, by the members of a secretive group, known only as the Inquiry, formed to prepare the scientific bases for American peace terms at the talks to end the Great War. A day after loading all of this aboard the USS George Washington, President Woodrow Wilson and an entourage of dozens of State Department officials, Inquiry members, sundry advisers and representatives for the American Commission to Negotiate Peace, joined hundreds of sailors on the German-built transport for the nine-day trip to the Breton coast of France. Once at sea, the passengers quickly settled into a routine that

\footnotetext{
1 "Newspaper Clipping," N.D.1917 (Series 2, Box 41), Charles Seymour Papers, Manuscripts and Archives, Yale University Library. (Hereafter referred to as Seymour Papers).
} 
included the president's regular two-mile walks around the deck of the ship, arm-in-arm with his wife. ${ }^{2}$

Despite the mundane rhythm of life on the ship, those aboard grasped that the people and ideas being ferried to Europe were extraordinary. This was the first time that an American president was officially visiting Europe, and he had taken the unusual step of placing himself at the head of the Commission to Negotiate Peace. But perhaps most significant was the power and appeal of Wilson's ideals: of a world built on self-determined nations, governments built on liberty, and an international league to cement the world together, debuting in a Europe torn apart by imperial rivalry and hungry for a viable alternative internationalism.

Buoyed by these ideals, the highlight of the brief trans-Atlantic voyage was, for some of the experts aboard, the president's unveiling of the secretive Inquiry to a select few others. After hearing from a young man named William Bullitt that some specialists were concerned and confused about their roles in the coming negotiations, Wilson called several key figures to his quarters. ${ }^{3}$ There, he joyfully revealed his secretive cabal of social scientists and told of

\footnotetext{
2 "Big Fleet to Meet Wilson; Ten Battleships and 28 Destroyers Will Be in Escort," New York Times, 4 December 1918, 3; Merrill D. Peterson, The President and His Biographer: Woodrow Wilson and Ray Stannard Baker (Charlottesville: University of Virginia Press, 2007), 143-144. Margaret MacMillan's account of Wilson aboard the George Washington uses the less than sympathetic account of William Bullitt to portray him as a recluse drawn in to a private existence with his wife and reluctant to speak on any preparations. Given the number of conversations between he and his immediate colleague in the Peace Commission, Tasker Bliss and Colonel House, it is more likely that Wilson was observing a distinction in rank reinforced by the arrangement of the converted and classed cruiser, that demanded messages move through channels of command rather than horizontally. See Margaret MacMillan, Paris 1919: Six Months that Changed the World (New York: Random House,2003) 1-9.

${ }^{3}$ Sigmund Freud and William Christian Bullitt, Woodrow Wilson: A Psychological Study (New York: Houghton Mifflin Co., 1967), 205-206.
} 
the impressive preparations the George Washington now carried. ${ }^{4}$ The Inquiry members present were elated, both that the president was aware of their existence, and that he seemed to see think they were highly important. "It is really an historic occasion," said one historian from the Inquiry, "because it is absolutely the first time the President has let anyone know what his ideas are and what his policy is." Wilson, he continued, "explained that he could not know the details of all the questions" and because of this, "would be forced to rely on the information we gave him." The president, the historian later recalled, told the experts in his quarters that night that he "wanted us to come to him freely and that we must expect him to call on us."

This was a relief for the 21 Inquiry men who had been chosen for Paris. Unlike their social scientific colleagues working in similar scholarly groups for France, Britain and Belgium, the arms' length "study group" had enjoyed a significant degree of institutional autonomy from its formation to its short-lived dissolution the week before the George Washington left port. Initially, the Inquiry executive was worried that the select few asked to attend the talks would be put to work for Secretary Lansing's State Department-like the division of Military Intelligence and other organs had during the warbreaking apart the already fragmented group of scholars and intellectuals. ${ }^{6}$ With Wilson's casual speech in his chambers that night, such fears began to

\footnotetext{
${ }^{4}$ Peterson, The President and His Biographer, 206.

${ }^{5}$ Charles Seymour to his family, 10 December 1918, $P W W$ 53: 18.

${ }^{6}$ Smith, American Empire, 143-145.
} 
retreat. Still, the group knew that the task for which they had been tapped was enormous.

Poland, Yugoslavia, Czechoslovakia, Belgium, France, Italy, the Balkan region, and Germany had all emerged from the horrendous violence of the war in territorial, political and, perhaps more fundamentally, social flux that made them ripe for new conflict and revolt. Rivaling claims to nationhood, territorial boundaries, resources, and strategic interests would noisily compete for American sympathy. One attendee recalled Wilson telling his new confidants to block out all these dissonant interests: "Criterion not who are intellectual and social or economic leaders but who form the mass of people," he told them, so that those with a case for nationhood established their government on "liberty-that is the kind of government they want."? Even as European governments were sending repeated cables through American diplomatic channels demanding clarification of what such a criterion meant, Wilson lectured his audience that European diplomacy and nations were bankrupt. The world yearned for a system of self-determined nations.

Wilson's speech on the George Washington, at least for the Inquiry men who later recalled it, was a clear re-emphasis of his widely disseminated and immeasurably influential "Peace without Victory" address to Congress on January 22, 1917. There he had argued most clearly that a lasting peace depended on building an international order around the "principle that

\footnotetext{
${ }^{7}$ MacMillan, Paris 1919, 9-11.
} 
governments derive all their just powers from the consent of the governed, and that no right anywhere exists to hand peoples about from sovereignty to sovereignty as if they were property."8 As Thomas Knock has noted, Wilson understood that by offering a penetrating critique of European imperialism, the US was entering the Paris talks with a universal criterion that (though it mostly applied to Europe in Wilson's mind) offered the self-governed nationstate as the ontological core of an international system. ${ }^{9}$

The George Washington arrived in the French port of Brest on December 13,1918 , to a vibrant military and citizen tribute. Bretons thronged to the pier in their best clothes, climbing to the top of lampposts and rooftops in the hope of stealing a glance at the man one observer called "le grand homme," waving signs and banners welcoming Wilson as the "Champion of the Rights of Man" and the "Founder of the Society of Nations." ${ }^{10}$ The next day, Wilson was greeted in Paris with similar excitement, travelling by open motorcar down the Champs Elysees surrounded by more banners and chants of "Vive Wilson! Vive l'Amérique! Vive la liberte!" Commission settled into its accommodations, Wilson traveled across Western Europe to meet with other governments, and was received with enthusiasm and reverence wherever he went. The near millennial hysteria one scholar

\footnotetext{
${ }^{8}$ An Address to the Senate, 22 January 1917, $P W W, 40: 537-539$.

${ }^{9}$ Thomas J. Knock, To End All Wars: Woodrow Wilson and the Quest for a New World Order (Princeton University Press, 1995).

${ }^{10}$ Peterson, The President and His Biographer, 144.

${ }^{11}$ Manela, The Wilsonian Moment, 19; MacMillan, Paris 1919, $15-17$.
} 
has called "the Wilsonian moment" was a sign that Americans had struck a chord of hope on the heels of a catastrophic, desperate war. ${ }^{12}$

Yet, veiled behind the excitement for the great man brewed a subtle but important power struggle among the experts sects within the American delegation. Within three days of arriving in Paris, by the time Wilson sat at the table with other allied powers to draft terms of peace with Germany, the small cadre of former Inquiry social scientists who so recently worried about serving the State Department had managed to almost entirely invert the chain of command they had feared, placing the State Department and Military Intelligence at their service-all with Wilson and House's consent. ${ }^{13}$

The Paris Peace talks are rightly treated as momentous. The six months of negotiations (18 January -28 June 1919) in Paris eventually culminated in a series of treaties that would end the First World War. The heads of states from the major allied powers-Britain, France, Italy, the US and to a much lesser extent Japan-assessed the claims of sovereignty put forward by different populations, judging them against their own state data and strategic interests. These negotiations, and the treaties they produced-including the Treaties of Versailles, St. Germaine and Neuilly-ushered in an age of internationalism where the self-determined nation-state became the central unit of a global, collective security system. ${ }^{14}$ Wilson's certainty of America's role as conduit

\footnotetext{
${ }^{12}$ Manela, The Wilsonian Moment.

${ }^{13}$ Gelfand, The Inquiry.

${ }^{14}$ Eric Hobsbawm, Nations and Nationalism since 1780: Programme, Myth, Reality (Cambridge:

Cambridge University Press, 1992), 131-134.
} 
for the opinions and aspirations of "the people" and not the social, political and economic elite of a country, entrenched in his emphasis on "selfdetermination", continues to focus historical debate on the merits, realism, idealism, problems and benefits of Wilsonian internationalism-commonly referred to as "Wilsonianism." 15 Rather than taking on this debate, this chapter proposes that Wilsonianism might be better understood as a convergence of discourses, as a moment that reveals both the dissimilarities and commonalities between the liberal internationalism that dominated American policy during World War One and those various social and civic variants that we have already examined.

Wilsonianism was more than just liberal idealism, a "new diplomacy", collective security, or an international system meant to stand up to rival communist internationalism (although it was still all of those). By focusing on the social scientists and the peculiar ontology of the nation they brought from the Inquiry to the Paris talks, this chapter sees Wilsonianism as part of the longer development of liberal governmentality that positioned the American state and its liberal, non-statist, social scientific expert at the core of both internationalism's representation and conduct. Wilsonianism is already understood as a profound moment in self-consciousness about the nation-state

\footnotetext{
${ }^{15}$ For an overview of the works on Wilson see, Elizabeth Mckillen, "The Unending Debate over Woodrow Wilson and the League of Nations Fight," Diplomatic History 27 (2003): 711-715. Some of the works that have addressed the dichotomy of Wilson versus Roosevelt as idealism vs. realism are, Cooper, The Warrior and the Priest; Frank Ninkovich, Modernity and Power: A History of the Domino Theory in the Twentieth Century, (Chicago: University of Chicago Press, 1994); Ninkovich, The Wilsonian Century; Strobe Talbott, "Self-Determination in an Interdependent World," Foreign Policy 118 (2000),152-163.
} 
as a unit of political and social organization. ${ }^{16}$ The Inquiry, as a historical case study, sheds light on the underpinnings of this new rationalization of internationalism: changes in the sites of authority, types of experts, institutions and knowledge considered best able to define states in the international.

To that end, the first part covers the emergence of the Inquiry, and the attempt to play up its arms-length distance from the American state. All key players were, we will see, careful to separate the investigative group from much of the scrutiny that accompanies state apparatuses, while keeping it close enough to substantially influence policy. Their objectification of a particular ontology of the nation state both stemmed from and justified this distance. It affirmed their assumption that movement towards a more global society depended on management by experts who understood the functions of nation-states but were not beholden to them. In the second part, I argue that the Inquiry further broadened the legitimacy of the social scientific expert by working with other international organizations to develop the empirical foundations for a peace. At the same time as they used these linkages to

\footnotetext{
${ }^{16}$ For examples of studies touching on the importance of religion in Wilsonian statecraft see: Lloyd E. Ambrosius, Wilsonianism: Woodrow Wilson and His Legacy in American Foreign Relations (New York: Palgrave Macmillan, 2002); Trygve Throntveit, "Leading Them to the Promised Land: Woodrow Wilson, Covenant Theology, and the Mexican Revolution, 1913-1915," Journal of American History 98 (2011): 234-235. Interesting though they are, I am not concerned here with the debates around Wilson's character, or the attributes of Wilsonianism that made it both so powerfully appealing and so hugely disappointing to a world convinced of its possibility. Certainly, elements of Wilson's religious upbringing and dogmatic manner saturated his rhetoric and made him an awkward foil to Lloyd George and Clemenceau at the Paris Peace talks. It is also impossible to ignore the volumes of writing that have pointed out, rightly, Wilson's difficult and convoluted conception of self-determination. What I am concerned with, however, is mapping out how this ambiguity and vagueness in Wilsonianism's tortured relationship with self-determination opened the way for social scientific knowledge, experts, and institutions to change the American understanding of internationalism.
} 
highlight and demonstrate the transnational character of their knowledge, they pointed to the relationships of those other organizations to their respective states as proof that only the Americans had achieved a truly liberal organization. In other words, only the Inquiry, they said, had achieved the status of being "with, not of" the state, and therefore only they could lay claim to truly liberal knowledge. Building on the story of how American social scientists used the revision of American exceptionalism to feed a sense of their own exceptionalism as scientific arbiters of internationalism, the third section of this chapter quickly explores, in the context of the Versailles Treaty and the related concept of self-determination, how the Inquiry men who traveled to Paris pushed out legalists and diplomatists during the negotiations.

\section{The State, Social Science and the Crucial Space Between}

The Great War seemed to bring into stark relief that the US was vastly underprepared for a prominent role on the global stage. With the exception of the American Journal of International Law, established in 1907, and a smattering of courses offered at major universities like Yale, Chicago, Cornell and Michigan, as well as university-based clubs such as the Cosmopolitan Club of Chicago and an International Polity club at Harvard, there was little in the US to provide a forum for the cultivation of a deep understanding of the 
international system. ${ }^{17}$ While the country teemed with experts on Western Europe (particularly England and Germany), it soon became apparent that much of the rest of the world was a figurative "dark zone" in American knowledge. It left the American state with apparently little to muster. This is not to say that there was no available knowledge of areas beyond the US and Western Europe. Immigrants from across Eastern Europe and around the world populated America's great cities by 1917. But, when the US entered the war in 1917, Woodrow Wilson and other high-ranking politicians in the US realized that the American state had done little to learn of new Americans' former homelands or to organize American thought around an internationalism congruent with this diverse world. On the one hand, the lack of state-harnessed information and homegrown expertise was potentially embarrassing for the US: it not only seemed to affirm the European view of Americans as unworldly and naïve, but it demonstrated the lack of any administrative system to collect and act on social data.

On the other hand, it presented an opportunity. European nation states like France, England, and Belgium had years of state-centred imperial experience that had made their capacity to map, survey and think about much of the world integral to the interests of their empires and imperial states. Because the US did not have such institutions, Wilson did not need to build directly onto any State or War Department, nor did he have to build bureaus

\footnotetext{
${ }^{17}$ Gelfand, The Inquiry, 35.
} 
or departments that might continue after the war. ${ }^{18}$ Instead, he followed the executive model of presidents before him and personally managed questions of foreign policy, creating and funding ad hoc committees linked to temporary war-time funding at the President's discretion. ${ }^{19}$

When compared to Europe, the US appears a relative latecomer in professionalizing a bureaucracy to deal with foreign policy outside of the continental US. They had established a Foreign Affairs/State department in 1789, and ministers of cabinet were often sent as ambassadors to major countries. Moreover, the Department of War, also created in 1789, had long dealt with continental conflicts throughout the nineteenth-century focused on shoring up a still growing continental US. But, even with America's foray into overseas imperialism in the late 1890 s, these departments were largely staffed through patronage appointments that, while meritocratic by their own standard, did not reflect the standardized, transparent appointment and staffing procedures we associate with modern bureaucracies. Robert Wiebe has argued that the United States' foreign policy machinery seemed to languish under an old regime of provincial patronage even as it entered the First World War. The pre-1914 State Department, George Kennan has said,

\footnotetext{
${ }^{18}$ This is not to say that the US had no colonial experience, but rather that it continued a tradition of relying on private and civic organizations to direct national attention and state policy in the international arena. Histories of the State and War departments underline the degree to which the American Foreign Service before World War One was small and unspecialized. See Robert Schulzinger's The Making of the Diplomatic Mind: the training, outlook, and style of United States foreign service officers, 1908-1931 (Middletown, Conn.: Wesleyan University Press, 1975).

${ }^{19}$ Gelfand, The Inquiry, 40.
} 
was really a "quaint old place, with its law-office atmosphere." ${ }^{20}$ As one British diplomat noted in explaining the formation of the Inquiry, the American State Department had been so isolated from European international affairs that its records "did not contain much first hand information about European Peace Conferences of the past."21 In comparison with the much more centralized administrative systems of imperial states like France, Britain, Belgium and Germany, the US developed policy through a much more dispersed system of extra-state interests that appeared, at first glance, to work through democratic or civic pressure exerted onto the state (as with Venezuela) meant to prevent the concentration of power in state hands. ${ }^{22}$ In this way, the committees, inquiries and commissions that came out of World War One continued a longheld American tradition of distrusting administrative power within the state.

However, as previous chapters have shown, the equation of state power with genteel intellectual elites began to dissipate with the professionalization of new social scientists and their move into the modern industrial research university. It granted increasing authority to civic institutions at arms length from the state. Their path to that authority was through the production of specialized knowledge rather than attempting to hold the reins of state apparatuses directly. The impact of this academicization of social science was immense. By the time the US entered the war in 1917, more academics and self-identified social scientists were working in Washington than ever before,

\footnotetext{
${ }^{20}$ George Frost Kennan, American Diplomacy, 1900-1950 (New York: New American Library, 1951 ), 80.

${ }^{21}$ Sir William Wiseman, Copy of report on "The Inquiry," June 1917, House Papers.

${ }^{22}$ Wiebe, The Search for Order, 254-255.
} 
their numbers swelling with the successes of Wilson's "New Freedom" and the outbreak of war. As the historian Richard Hofstadter noted, "Military Intelligence, Chemical Warfare, [and] the War industries Board swarmed with academics, and Washington's Cosmos Club was reported to be 'little better than a faculty meeting of all the universities." 23 While the inclusion of academics into national bureaucracies has received the most attention, it is only a minor part of the larger story of how of social science came to redefine, and be defined by, the search for international governance. ${ }^{24}$ The events, trends, enablements and constraints that made room for Wilson to call the Inquiry together are an ideal window onto this larger story.

Both Woodrow Wilson, and Theodore Roosevelt before him, had the respect of scholars and academic reformers-Wilson for his role in the reorganization of university curriculum and co-operative institution building as President of Princeton University, and Roosevelt for his prolific historical writing and for aiding the $A H A$ in its ventures to establish a national archives. ${ }^{25}$ But progressive politicians, especially Wilson, strategically played down their academic pasts to avoid being branded part of an elite. ${ }^{26}$ Wilson realized that there was a lingering populism in American culture and he was quick to appeal to popular sentiments about the virtues of labor, manliness

\footnotetext{
${ }^{23}$ Richard Hofstadter, Anti-Intellectualism in American Life (New York: Alfred A. Knopf, 1967), 211.

${ }^{24}$ Ibid., Gruber, Mars and Minerva; Mark R. Nemec, Ivory Towers and Nationalist Minds: Universities, Leadership, and the Development of the American State (Ann Arbour: University of Michigan Press, 2006).

${ }^{25}$ Hofstadter, Anti-Intellectualism, 207; Morey Rothberg, "Introduction: A Home for History," John Franklin Jameson and the Development of Humanistic Scholarship in America: Volume 3, The Carnegie Institution of Washington and the Library of Congress, 1905-1937 (Athens: University of Georgia Press, 2004), $10,44$.

${ }^{26}$ Michael Kazin, The Populist Persuasion (Ithaca: Cornell University Press, 1998), 32.
} 
and, most importantly, nationalism when reaching for political power. Moreover, progressivism was itself devoted to "democratization" of American political institutions to take them out of the hands of economic oligarchs who had controlled state apparatuses through patronage within tight bourgeois kinship circles. ${ }^{27}$

Seen as an enlightened intellectual by many academics, colleagues and former teachers at Princeton and Johns Hopkins universities, Wilson was cautious about wearing the mantle of academic expert as part of his political identity. But he was less hesitant in embracing the idea that social scientists could understand society in a more objective way than politicians. The rationale for such an idea was twofold. First, in Wilson's vision, the social subsumed politics as one of many threads that composed a larger assemblage identifiable as a society. Social knowledge, in other words, came above politics. Second, and resultantly, this meant that a full and fair understanding of "the social" was beyond the comprehension or understanding of those politically rooted individuals who operated in, and therefore only served, their state. As Wilson argued in The State (1898), "broad and careful wisdom whose conclusions are based upon the widest possible inductions from the facts of political experience in all its phases ... is quite beyond the capacity of most thinkers and actors in the field of politics." States, Wilson argued, had the capacity to be "beneficent and indispensible organ[s] of society," but

\footnotetext{
${ }^{27}$ For more on these kinship ties at the turn of the century see T. J. Jackson Lear, No Place of Grace: Antimodernism and the Transformation of American Culture, 1880-1920 (Chicago: University of Chicago Press, 1981), xii-xvi.
} 
society itself "is vastly bigger and more important than its instrument, Government." 28

This treatment of government as a tool of society that the state simply expressed, rather than actively directed, had two noteworthy effects. On the one hand, it gave special legitimacy to social scientific management of political concerns by constructing a vacuum of leadership power where government had traditionally been. But in doing so it also articulated a vision of society as a sort of body in which distinct spheres could be isolated, observed, and steered. There could even be a science that treated politics as a distinct field of knowledge and human experience. This vision supported the hegemonic philosophical compartmentalization of the lived-world into knowable spheres, built on historically and sociologically emergent distinctions such as private and public, government and corporate, and collective and individual. For Wilson, as in today's liberal political culture, such distinctions needed to be maintained.

For example, the political class in the US had to understand that the state needed to create the conditions for what Wilson called "necessary cooperation" between social groups and individuals. But it could not and would not meddle in the "private morals" that "belong to the sphere of separate individual responsibility." 29 The introduction of experts, coming from social science professions that had cut their teeth on questions of trade,

\footnotetext{
${ }^{28}$ Woodrow Wilson, The State: Elements of Historical and Practical Politics (Boston: D.C. Heath, 1898), $629-31$.

${ }^{29}$ Ibid., 632-639.
} 
sanitation, and moral regulation, and which had built reputations as reformist bodies, could have easily been interpreted as a threat to this liberal balance of equality and individuality, private rights and public responsibility, state and society. Yet if the social scientist was not explicitly connected to the state, nor concerned with overt political control over the individual, his or her role was less problematic. If they worked with professional and non-governmental groups in the civil-scientific (yet still patriotic) study of society, and so long as they lacked access to the power of the state to mandate morality, much of the lingering republican and populist concern about elites using the political to control social change could be alleviated. Rather than governing through the state, social scientists provided a way to manage society that both criticized and used the state as one tool among many to elucidate what it presented as the natural laws and norms that governed society. Social science offered a fuller explanation of the nature of social conditions and human behavior by treating politics and the state as only constituent parts of a larger social picture that only social scientific rationality could comprehend. It was with this distinction between expert and state in mind that Wilson called together a group of social science experts to information-gather in advance of eventual peace talks.

\section{The Formation of the Inquiry}

Wilson along with his close advisers understood the domestic and foreign relations implications of appearing to turn to experts in war and peace 
planning. The president needed, however, to avoid the appearance of planning for a peace before the war was won, let alone working toward aims that were inconsistent with those of his international associates. At the same time, however, as the war progressed, it became clear that some statement of associate war aims was needed, if only for propaganda purposes. But any such statement, aside from its international implications, was bound to attract hostile attention from the diverse constituency of Americans who had come together in the spring of 1917 to support the war. How, then, to begin the process of articulating a progressive peace plan that both avoided these pitfalls and his earlier public rejection of "a government of experts." To navigate this treacherous political terrain Wilson proposed a quiet compromise that played to a broad constituency of progressive-liberals, liberals and conservatives, dodging any apparent pandering to academics or experts that would scare off a significant electoral segment or the appearance of partisan patronage. ${ }^{30}$

With this in mind, Wilson bypassed the State Department and the recently appointed Secretary Lansing, in whom he proclaimed early on to have little confidence anyway. Instead, he used his authority to call upon Colonel Edward House, his close personal aide with no political title, to

\footnotetext{
${ }^{30}$ Cited in John W. Davidson, "Wilson in the Campaign of 1912,", ed. Earl Latham, The Philosophy and Policies of Woodrow Wilson (Chicago: University of Chicago Press, 1958), 94; Hofstadter, AntiIntellectualism, 210; Harold Orlans, "Academic Social Scientists and the Presidency: From Wilson to Nixon," Minerva 24 (1986): 172-204.
} 
"quietly gather a group of men." ${ }^{31}$ House quickly set to contacting some of the most prominent and respected progressive Democrats and League to Enforce Peace supporters in the US, despite having tense relationships with many of them. Among those House tagged were New Republic editor Herbert Croly and A. Lawrence Lowell, the sitting President of Harvard and an influential member of the League to Enforce Peace. ${ }^{32}$ These two confidants recommended dozens of other names for the skeleton of the still secret organization. House chose only three. Two came from Croly's list: the economic and technological historian James T. Shotwell, and Croly's wellknown and respected colleague at the New Republic, journalist Walter Lippmann. The third was House's brother-in-law, Sidney Mezes. Soon after accepting the position as director of research, Shotwell recommended Archibald Cary Coolidge (who was on Lowell's initial list but had then declined), and proposed Isaiah Bowman serve as the group's territorial expert. Bowman was a respected and shrewd geographer who made his reputation working as an editor with the American Geographical Society, and through his writing on South America. ${ }^{33}$ These four formed the first executive of the Inquiry, each carefully picked to play to particular political interests (even as they were meant to appear apolitical) or to consolidate professional

\footnotetext{
${ }^{31}$ Cited in Godfrey Hodgson, Woodrow Wilson's Right Hand: The Life of Colonel Edward M. House (New Haven: Yale University Press, 2006), 157.

${ }^{32}$ Importantly, Wilson had initially asked that House consider Felix Frankfurter as a primary figure in the formation of such a group. House, however, passed Frankfurter over at the early stage of contacting potential chief administrators and advisors. Wilson to House, 2 September 1917, House Papers; for broader context see Smith, American Empire, 118-119.

${ }^{33}$ Smith, American Empire, 134; Helen Delpar, Looking South: The Evolution of Latin Americanist Scholarship in the United States, 1850-1975 (Tuscaloosa: University of Alabama Press, 2007), 77, 95.
} 
and logistical resources inside the nascent commission. Sometime in the first meeting of this executive group, Shotwell suggested "the Inquiry" as a deliberately imprecise moniker for the group, proposing that the name would "blind the general public, but would serve to identify it among the initiated." 34 The name stuck.

There can be no doubt that the initial assignment of Mezes, Lippmann, and Shotwell to the Inquiry was proof, at a minimum, of political maneuvering by House and Wilson to hide the peace group from the public by dealing solely through their personal networks. But it was strategic in an additional way. House knew that inviting the influential writer, Progressive insider, and possible dissident, Walter Lippmann into the Wilsonian tent would limit Lippmann's formidable capacity for devastating public critique. ${ }^{35}$ In a letter to the Inquiry Executive after Lippmann left for other work, Bowman claimed that House has only admitted Lippmann because he felt "the Administration had to cooperate with the extreme liberals of the country," and that Lippmann was more cooperative than most. ${ }^{36}$ The decision to take on Mezes, above other locally esteemed experts on Europe, also ensured that the group was made up of only the most devout and trusted men. Placing an unquestionably loyal administrator at the head of the Inquiry where he could keep House abreast of

\footnotetext{
${ }^{34}$ James T. Shotwell, At the Paris Peace Conference (New York: Scribner and Sons, 1937), 6-8.

${ }^{35}$ Smith, American Empire, 119-120.

${ }^{36}$ Bowman to Shotwell, "Notes on the Inquiry," 30 November 1918 (box 12), Shotwell Papers.
} 
every development might prove an important counter-balance to the fiercely independent-minded Lippmann. ${ }^{37}$

But when it came to staffing the group with personnel-the drawing in of "rank-and-file" experts-the Inquiry faced the challenge of casting a wide enough net in secret. The group would eventually number over 126 members, only including those directly employed and on staffing records, and not the dozens of other proxy contributors who were commissioned for reports but mostly left in the dark on the actual administrative running of the group. Gelfand, who authored the most definitive institutional history of the Inquiry, emphasized (like subsequent histories that deal with the organization) that it was late to the staffing game. It began well after the US entered the war, which meant that "the persons most eminently qualified to work on an Inquiry assignment could [often] not obtain a leave of absence" from prior wartime obligations on committees or soldiering. ${ }^{38}$ This, along with the apparent desire for secrecy, Gelfand argued, is why "the Inquiry's correspondence is

\footnotetext{
${ }^{37}$ Gelfand, The Inquiry, 3. It is worth noting that Coolidge was not entirely warmed up to the Wilsonian notion of international collective security and expounded a more traditional real-politick concern with Great Powers diplomacy between nations, especially in his examination of the history of the US and France as World Powers. Archibald Cary Coolidge, The United States as a World Power (New York: The Macmillan Company, 1908). Also see Archibald Cary Coolidge, "France as a World Power," 1910 (Series: Writing, 1895-1922, box 11-12), Papers of Archibald Carry Coolidge, Harvard University Archives (HUD1299). Coolidge's views were more conservatively nationalist than those Wilsonians who hoped to deemphasize the importance of the great powers in Europe. The influence of conservatives nationalists like Coolidge on the Inquiry remains under-examined, but when one compares what Wilson asked the group to do with how it ended up drawing up borders it seems, as Chapter 6 explores more closely, that they had a much larger effect than many have credited them with. For one of the few pieces that touch on Coolidge's influence see Arno J. Mayer, Politics and Diplomacy of Peacemaking: Containment and Counterrevolution at Versailles, 1918-1919 (New York, 1967), 369. For more on the conservative use of ethnicity to guide American cartography at Paris See Jeremy Crampton's "The Cartographic Calculation of Space," 731-752; Smith, American Empire, 177-178.

${ }^{38}$ Ibid., 71.
} 
replete with instances of members who brought in colleagues and friends rather than attempt to comb American academic institutions in search of the best qualified candidate." ${ }^{39}$ While partisan political affiliation (Democrat or Republican) was rarely a primary concern, the screening of candidates was explicitly designed to ensure that only the most "trusted individuals" were allowed in. The criteria of what constituted "trusted" was not explicit but records reveal an instable mixture of personal connection to House's inner circle and possession of some professional qualification and assets.

Historians since Gelfand have argued that the Inquiry was mainly concerned with balancing personal loyalties, which maintained some secrecy, against the need to reach beyond these inner circles in an effort to attract genuinely qualified experts on internationalism, economics, regional anthropology, history, and sociology. But from another angle, the secretiveness of the Inquiry proves an invaluable toehold into how national political interests and the social sciences worked cooperatively, though with different intentions, to legitimate each other without appearing incestuous. Social science professionals played an integral, if at first unwitting, role in legitimating an American vision of global order that depended increasingly on non-governmental and social scientific expertise. As the Wilson administration navigated the tensions created by clashing anti-war, peacewithout-victory, and total victory groups in American society, they were careful to situate the Inquiry as a non-state committee, generating a crucial

\footnotetext{
${ }^{39}$ Ibid., 49.
} 
sense of space between state-government and social scientific policy construction-a space that the members of the Inquiry and those in government were careful to maintain. As we will see, maintaining this image was particularly difficult in so far as House and Wilson seemed at pains to keep the group's existence a secret so that when, invariably, its formation leaked out, it was even more important to stress publicly that the Inquiry was somehow a non-partisan, if not entirely apolitical, body.

\section{The Leak: Stateless Scientism in US State-formation}

Just days after House set about collecting names for the Inquiry in September 1917 , news of the organization leaked into newspapers across the nation. The Philadelphia Public Ledger's Washington Correspondent, Lincoln Colcord, first broke the story on 26 September. "As is well known, both France and Great Britain have for some time been making active preparations in their own behalf for the Peace Conference," Colcord wrote, "Thus, there has lately been felt to be a growing need in America for a series of similar activities unless we are able to be greatly handicapped at the Peace Conference when it comes." ${ }^{40}$ At the time, Colonel House attributed the Ledger leak to Felix Frankfurter, a well-known and respected jurist in progressive circles who had access to the US government. According to Gelfand, Frankfurter was among

\footnotetext{
${ }^{40}$ Philadelphia Public Ledger, 26 September 1917. Cited in Gelfand, 39. I was unable to trace the actual article from the Ledger, in the volume referenced, finding only a dispatch from Washington communicating that Secretary of State Lansing "denied reports that Colonel E.M. House is to be sent to Europe on a peace mission by President Wilson, or that a so called "Peace-Bureau" is to be established by the United States in Entente nations, Administration officials take the ground that it is premature to discuss peace or to lay the basis for peace negotiations in the near future," 1 (emphasis added).
} 
the first to tell Wilson of the existence of European study groups, urging the president to form an American counterpart. He was even short-listed to lead the organization, but was instead passed over and left to serve as the special assistant to Secretary of War, Newton D. Baker. It is unclear if Frankfurter learned directly of the Inquiry through this position, or if it was leaked to him through his personal connections to its executive members, including Lippmann, David Hunter Miller, Croly, and Mezes. ${ }^{41}$ Regardless of how he found out, historians have accepted the allegation that he was the source of the leak, focusing almost entirely on the document trail available in Inquiry documents-the key set of clues in the blame game-while ignoring both the tone of the message and the strategic importance of finger-pointing at the time of the leak. ${ }^{42}$ The messaging of the leak, and House's own reaction to the news, points to a different scenario: that this was a controlled leak by House himself meant to placate growing dissent within progressive-liberal circles who were beginning to fear, on the basis of Wilson's wartime policies, that the administration was no longer interested in maintaining the broad base of support that had helped secure his 1916 election.

The Inquiry's own correspondence shows that media reports of the group were contradictory and more than a little confused about what they

\footnotetext{
${ }^{41}$ For Frankfurter's correspondence with Inquiry men after the leak see Steel, Walter Lippmann and the American Century, 129-131.

${ }^{42}$ House alleged that Frankfurter shared news of the Inquiry with William Bullitt, then working for the Ledger, who spilled it from there to Colcord, who also happened to be a friend of House and Washington bureau chief for the Ledger.

For more on Frankfurter and his relationship with Baker see Gerald Gunther, Learned Hand: The Man and the Judge (New York: Knopf, 1994), 221-222.
} 
were actually reporting. Some news focused on the group as a strictly "academic" endeavor, while others proclaimed it was concerned with "economic reconstruction." Still others emphasized that it was the mustering of a peace plan to offset Europe's inevitable ambition to try to scuttle plans for a new diplomacy. All reports were remarkably tempered and cautious, especially those in newspapers with close ties to the White House and the Wilson Administration. ${ }^{43}$ Little ink was spilled describing the group's makeup, and only cursory attention was given to either its possible purpose, or why the State Department, when asked about the group, denied knowing anything of its existence. Articles in papers in the American northeast US did little to interrogate the group or its meaning and, significantly, never referred to its membership as experts, instead treating them as arm's-length "advisors," "friends" or "confidants" who were "information gathering," but who had no direct connection to any official peace-policy initiative. ${ }^{44}$

The White House was not shocked by the leak. Rather, House was resigned to its inevitability, assuring the president and Inquiry executive that his personal ties with the reporters of progressive papers would allow him to manage or at least steer journalists' readings of the information. As Christopher Lasch has remarked, the network of interpersonal relations that

\footnotetext{
${ }^{43}$ See for example: "Col. House to Get Peace Council Data," The Washington Post, 28 September 1917, 1; "US Preparing for Peace Parley, But Taking No Step to End War," The Washington Post, 27 September 1917, 1; "America to Speak in Her Own Voice at Peace Table," New York Times, 29 September 1917, 1.

44 "America to Speak in Her Own Voice at Peace Table," New York Times, 29 September 1917, 1. Importantly, the mantle of "expert" would not appear for these Inquiry men until the smaller group travelled to Paris.
} 
became imperative to American mobilization during World War One-which also became important to the day-to-day secrecy of the Inquiry-predated the war, and often blurred the lines of access to what may have been otherwise considered state secrets. This matters because while much has been made of the leak supposedly emanating from Frankfurter, it seems just as likely that the information was given directly to Colcord. According to Lasch, "few people outside the Wilson administration, in the critical year of 1917, were in such constant contact with House as Lincoln Colcord." 45 House's own writings maintain that Colcord was open in personal and public writing that he felt the war offered a formative opportunity for "a new more liberal order of internationalism," in which "matters may be settled without resort to arms."46 While the relationship between House and key progressive newspapermen was at least partially strategic, exchanges between House and Colcord were especially candid, with House often "confid[ing] opinions which were not only not intended for publication but which, as he told Colcord, he had not confided to anyone else." ${ }^{47}$ Indeed House claimed that he used his connections with the Ledger to suppress the story for three weeks. And the

\footnotetext{
${ }^{45}$ Christopher Lasch, The New Radicalism in America, 230. House helped Colcord receive the prestigious Washington bureau post from which news of the Inquiry would leak. Colcord had earned the position through his ability coupled with an unflinching admiration for House and their shared sense that the boundary between professional duty and public good was blurred by a deeply spiritual concept of a "majority spirit of service," as Colcord called it.

${ }^{46}$ Lincoln Colcord, "The United States as a Sea Power," New Republic, 30 December 1916, 241; Lasch, The New Radicalism, 237

${ }^{47}$ Lasch, The New Radicalism, 235-237.
} 
eventual release of the news had a significantly measured tone and message. ${ }^{48}$

That journalists were careful to self-censor is borne out in two ways. First, initial stories on the Inquiry emphasized that any experts (professors or independent economists in name) were working with House to "assemble data," in a manner that simply followed the lead of other nations that had already convened similar groups. Accepting House's rationale, one journalist wrote that its purpose was simply to equip the US so it could counter Europe's "balance of power" thinking with a plan for a "community of power" that would ensure "an organized common peace." 49 Second, as with Colcord's original story, the vast majority of newspapermen were extremely careful not to insinuate that the group was preparing for peace, lest they open Wilson to criticisms he was being "soft" on Germany. Following on the heels of the Papal request for peace talks (which had only been formally revealed in late August), total-victory proponents, mostly within the League to Enforce Peace, but others like Roosevelt, stated: "What we're interested in is war, not peace." ${ }^{50}$ At a Unitarian conference in Montreal in late September, former US and LEP president William Howard Taft announced his support for Roosevelt, echoing the sentiments of much of the nation that "America and her allies

\footnotetext{
${ }^{48}$ House to Wilson, 3 October 1917, House Papers.

49 "State Department Confirms Appointment to Gather Data for Peace Parley," New York Tribune, 29 September 1917, 4.

${ }^{50}$ Philadelphia Public Ledger, 22 September 1917, 3. Also see, "Roosevelt's Great Kansas City Speech," Leavenworth Echo, 28 September 1917, 1, 4.
} 
cannot concede peace until they conquer it." ${ }^{\text {51 }}$ Even progressive papers on close terms with the White House, such as the Ledger and the New York Evening Post, were at the forefront of calls for full national commitment to the war effort; they were often guilty of some of the most hyperbolic expressions of nationalism.

The Wilson administration also faced a significant and perhaps welldeserved collapsing of faith among anti-war radicals and key leftprogressives. Many liberals and socialists in the US held out hope that House could defend the cause of universal liberalism within the Wilson camp throughout 1916-1918, and stand against the reactionary forces that inevitably emerge during a war. But hope and trust were visibly crumbling as early as the summer of 1917. As American society became increasingly paranoid about the specters of pro-German and anti-war sentiment, accusations of disloyalty or enemy sympathy became more common and carried evermoredevastating legal and social consequences for those it was (most often unjustifiably) leveled against. In June 1917, Wilson and Congress approved the Espionage Act, which made it a crime to cause or attempt to cause insubordination, disloyalty, mutiny, or refuse duty in the military. Whether it was because Wilson believed a measured crackdown by the state on dissidents better than leaving it to the masses, or because more reactionary forces in the Wilson administration interpreted the Espionage Act as an

\footnotetext{
51 “Unitarians, Led by Taft, Vote Down Pacifists," New York Tribune, 27 September 1917, 2.
} 
opportunity, the result was the same. ${ }^{52}$ Liberal, progressive and leftist influence was smothered throughout America. Wilson's Post Master General, Albert Sidney Burleson, quickly and infamously employed the Espionage Act to strip the postal privileges of publications critical of American allies or that suggested "the government is controlled by Wall Street or munitions manufacturers or special interests." 53 The New Republic, headed by Inquiry insiders Croly and Lippmann, was one of the first to be held back. Croly, and other prominent journalists such as Upton Sinclair, and war socialists like William English Walling or John Spargo (all recent converts to the war effort) wrote to Wilson appealing for cooler heads, and calling the behaviour "pitiful and childish ignorance." Wilson showed no signs of remorse, however, and insisted that Burleson was "misunderstood" and was simply being "most conservative in the exercise of these great and dangerous powers." 54 With sympathy for dissent waning, publications were forced to self-police their content to ensure distribution and avoid disloyalty charges, all but quelling public opposition to the war in liberal publications. It left progressives like Walter Weyl, also a New Republic editor, to arrive at the anxious conclusion

\footnotetext{
${ }^{52}$ For an interpretation that emphasizes Wilson as the primary mover in the clampdown on dissidents because of concerns over domestic security see Ronald Schaffer, America in the Great War: The Rise of the War Welfare State (New York: Oxford University Press, 1991), 3-108. For an interpretation that emphasizes the conservative elements of Wilson's administration see Kennedy, Over Here, 78-81.

${ }^{53}$ The Espionage Act of 1917 (Pub.L. 65-24, 40 Stat. 217, enacted June 15, 1917); Kennedy, Over Here, 78-81; Donald Johnson, "Wilson, Burleson, and Censorship in the First World War," The Journal of Southern History 28 (1962): 46-58.

${ }^{54}$ Upton Sinclair to Wilson, 27 October $1917, P W W, 44 ; 467-472$; Wilson to Croly, 22 October 1917 , $P W W, 44 ; 472-78$,
} 
that "liberalism is crumbling at out our ears, and we are doing little or nothing." 55

In this climate, academics and intellectuals, accustomed to possessing at least a certain measure of insulation from public emotion, were under particular scrutiny. As other social institutions such as the church, labour unions and the press turned to support the war and the state, many of them publicly abandoning support for radicals and anti-war pacifists, the university came to be seen as a last harbour for anti-war dissidents. Under the gaze of fellow pro-war liberals, academics faced a significant problem: the academy had to avoid being collectively painted with the brush of disloyalty when individual professors publicly dissented. It was relatively more protected from immediate economic pressures such as the fiscal viability connected to selling and distributing papers or magazines that had made journalistic publications reluctant to court controversy. But academic and professional associations-for example those connected to the social science disciplineswere less and less ideologically protected from an apparent need to prove one's nationalist grit.

While the division between public-intellectualism and academic research was much less defined at the turn of the century than it is perhaps today, most social scientists still lacked access to broadly consumed publications or outlets that would reach far beyond their professional circles.

\footnotetext{
${ }^{55}$ Charles Forcey, The Crossroads of Liberalism: Croly, Weyl, Lippmann and the Progressive Era, 19001925 (New York: Oxford university Press, 1961), 288.
} 
Instead, most of them were dependent on their host institution's ability to publicize its patriotic nationalism. There can be little doubt that the professoriate became a soft target for the hyper-nationalist civic organizations that sprung up across the country. ${ }^{56}$ Even though universities forcefully promoted their patriotism, vigilante groups, often led by well-established political elites, became amateur sleuths and loyalty enforcers, providing newspapers across the US with a constant stream of letters-to-the-editors and "tips" on lectures or any public dissent uttered by the professoriate. The hysteria swept universities, which had been generally supportive in the beginning, into increasingly public displays of support for preparedness and, later, war. Columbia, Yale, and Harvard Universities, to name three of the best studied, allowed their campuses to serve as training camps and barracks, and even to house military training facilities. Universities in larger industrial centres, for example Pittsburgh, as well as those in more agrarian areas, actually advertised and promoted their role in staffing factories with the industrial and managerial expertise needed to produce wartime supplies and weapons. ${ }^{57}$ The academic-intellectual class was doing everything it could to aid in the mobilization and war-effort. This was fertile ground for the Inquiry.

Granted, not all academics accepted America's role as a belligerent. But fears that the taint of "disloyalty" would spread from individual dissenters to the whole institution meant that public war-opposition was actively

\footnotetext{
${ }^{56}$ Clifford Wilcox "World War I and the Attack on Professors of German at the University of Michigan," History of Education Quarterly 33 (1993): 59-84.

${ }^{57}$ Nemec, Ivory Towers and Nationalist Minds, 185-92.
} 
discouraged or even on occasion punished by university administrations. In perhaps the most infamous case of the time, Nicholas Murray Butler, thenPresident of Columbia University and also a prominent member of the League to Enforce Peace, dismissed Henry Wadsworth Longfellow Dana, an English professor, and the well-respected social scientist and psychologist James McKeen Cattell, on the grounds that they were "encouraging disloyalty" by publicly opposing America's entry into the war. ${ }^{58}$

Their dismissal also illustrates an important ideological divide within the progressive camp, one that shaped the boundaries of professional discourse in the social sciences generally, and thus in the Inquiry as well. Newspapers across the US joined the chorus of hyper-nationalism, citing Dana's pacifism and Cattell's letter to Congress opposing sending troops to Europe, which Cattell readily admitted was justifiable grounds for dismissal. ${ }^{59}$ Some prominent colleagues, including James H. Robinson (Shotwell's adviser and mentor), Charles A. Beard, and John Dewey, went on record in the New York Tribune to express regret that "President Butler chose to silence free expression of opinion when we are trying to teach the German people to speak out freely against an autocratic Government." But these measured voices were mostly drowned out by a chorus of conservative and progressive publications alike-even those with direct editorial connections to House and

\footnotetext{
${ }^{58}$ Historians have explored how the dismissal of these two professors provided the formative event from which the Academic Freedom movement sprung in the US, and cemented support for the fledgling American Association of University Professors. See Richard Hofstadter and Walter P. Metzger, The Development of Academic Freedom in the United States (New York: Columbia University Press, 1955), 383-487.

59 “Columbia Ousts Two Professors, Foes of War Plans," New York Times, 2 October 1917, 1.
} 
the Wilson White House, including the New York Evening Standard and, most importantly, the Ledger. The same publication that would leak news of the Inquiry, and which largely padded that story, took a rather compromised position on the dismissal of the two Columbia professors. The Ledger argued that their dismissal was not "on all fours with the dismissal of Bemis and Nearing from other universities," for speaking out against industrial monopoly or for personal indiscretions. Stacking the dismissals up to the greater good, the Ledger proposed that "with the country at war and with President Wilson asking of all colleges and universities a most thorough rallying to the cause of democracy, this is not the time when the much-abused term, 'academic freedom,' can be invoked to cover offenses which, if they were widespread, would mean the downfall of all Governmental activity and the defeat of the great cause of the people." The message, a "clarion call to the patriotic," was loud and clear: "it behooves all to remember that their sacred duties are of more value in promoting freedom and democracy than are their rights."60 Within the atmosphere of the war, intellectuals and social scientists, like the rest of the liberal class in the US, were increasingly expected, to borrow from Franz Boas' contemporary observations, to accept that the "social ethical standards [of one's nation] are ... more fundamental than those that are general and human" and that these "ideals are or should be the true ideals of mankind." 61

\footnotetext{
${ }^{60}$ All cited in, "Columbia's Dismissed Professors," The Literary Digest, 20 October 1917.

${ }^{61}$ Franz Boas, "The Mental Attitude of the Educated Classes," The Dial, 5 September 1918, 146.
} 
Wilson and House understood that news of the Inquiry would have to walk a fine line between the forces of pro/anti-war interests as well as, more importantly, devoutly nationalist and humanist internationalist segments of the political class. While Wilson wished to see all references to the group kept out of the papers entirely, House proposed that since the story would inevitably get out, it would be better to manage it in a way that could work for the administration. When word of the Inquiry finally broke, Wilson's displeasure confused journalists on good terms with the administration: why would the President be "greatly annoyed...over the interpretation placed on the work of Colonel House that it is in line with a peace move by the United States"? The New York Evening Post's David Lawrence wrote the President and made the case that his coverage of the Inquiry "had nothing to do with peace negotiations" but rather emphasized that it he had made clear it was "an academic study ... vitally related to the future foreign policy of the United States." 62 This distinction between concrete plans for peace and academic study related to future foreign and economic policy was an intentional depoliticization of the charges against the Inquiry. When the New York Times followed up on the allegations that the organization might be part of early preparation for peace talks, it fed back to readers the government line that it "was denied explicitly and emphatically...[as] in line with a peace move by the United States," and that the group's primary purpose was actually the

\footnotetext{
${ }^{62}$ David Lawrence to Woodrow Wilson, 3 October 1917, $P W W$, 44; also see The New York Evening Post, 12 October 1917.
} 
exploration of "conditions that would confront the trade of the world after the war." ${ }^{\text {"63 }}$ The Inquiry's scope, even at this point, was not nearly so simple. But, the president did not want talk of peace circulating. "You newspaper men can have no conception of what fire you are playing with when you discuss peace now at all," he wrote to Lawrence; "the whole matter ought to be let alone." 64

When one considers the immense roster of progressives, liberal intellectuals, journalists and major public figures to which House turned for Executive staffing recommendations, it is little surprise that the story did not stay secret for long. News of the Inquiry, released as it was, offered concessions to most major interests. It gave anti-war and more "centrist" peace-without-victory circles a sign that House was working towards liberal ends, placing intellectuals at the heart of the coming peace project. But, as his comments to the New York Times show, House also played to conservativenationalist circles by binding news of the group to American beliefs in that nation's exceptional role in brokering a peace, and by emphasizing that the group would assure America's economic power at the war's end.

\footnotetext{
63 "Colonel House Studying After War Trade Plan," New York Times, 3 October 1917. Lawrence suggested that Louis D. Brandeis would be an ideal member of any organization with his experience as a jurist and on the question of a Zionist Palestine. It is the specific mention of Brandeis in this article, the Ledger article, and the New York Times article that has shaped much of the opinion that it was likely proZionists or Brandeis friends in government (Frankfurter being chief among them) that leaked news of the story; a notion that House did little to dispel in his correspondence with Wilson when House's (capitalizing on Wilson's own racialism) blamed "The Jews from every tribe" for their apparent determination "to break in with a jimmy if they are not let in." See Steel, Walter Lippmann and the American Century, 129-132. But this was more likely a scapegoat, and there is no empirical proof that Frankfurter leaked the news to Bullitt other than House's letters to Wilson insinuating as much. Importantly, this debate has distracted from the fact that progressives everywhere were aware of such an organization and wanted to become involved in it, as chapter 6 explores more closely. The story was already out, as the date on applications to the group in the Mezes Papers at Columbia University group attest to.

${ }^{64}$ Wilson to Lawrence, 5 October 1917, $P W W, 44: 309$.
} 
The day after the Ledger story, House suggested to Wilson that "it is better to have it out than to make a mystery of it and to have it discovered after the organization was underway." ${ }^{35}$ Perhaps House leaked the Inquiry to Colcord in a moment of openness, which Lasch notes was uncharacteristically common in their relationship. Perhaps it was a calculated release of information to multiple journalists friendly to Wilson and his already outlined ideas. Regardless of how news of the Inquiry was spread, for those who entered it in 1917 and 1918 the leak made the political cultural terrain clear: social scientists had to offer innovative ways to order the world in the coming peace talks, but they could not afford to question the shibboleths of patriotic nationalism, American sovereignty, and would challenge America's moral magnanimity and exceptionalism at their own peril. Their access and influence, as well as the appearance of objectivity, hinged on it.

\section{Social Science and Nationalism: Le Comité d'études and the British Commission}

In 1918 , the Inquiry was not the only social scientific body formed to study plans for peace. Rather, such groups were a shared phenomenon across the western world. Social scientific organizations flourished, thanks to a global convergence of principled thinking, first around the already present but growing assumption that the nation-state was the basic governmental unit, and second around the growing reliance on social scientists to bear out that

\footnotetext{
${ }^{65}$ House to Wilson, 3 October 1917, House Papers.
} 
vision. ${ }^{66}$ As this section shows, the social scientists in the Inquiry deftly managed the two "inextricably linked" emphases on the nation-state and social scientific knowledge to further legitimate their craft and, in turn, make American exceptionalism more central to the concept of a new internationalism that protected their authority by going beyond the traditional arbitrationist and legalist philosophies of an earlier generation. Their relationship with "sister"-organizations in Europe broadened the legitimacy of the social scientific expert, highlighting its transnational aspect, while also, paradoxically, using these other organizations as a foil to demonstrate their own group's exceptional disconnection from the state.

This shift in rationality was not a sudden development with the war, but it did enter into vogue with the conflict, as a once marginal transnational community suddenly became a powerful agent that could articulate an alternative international order to the balance-of-power system-the very system that had seemingly driven Europe and the world to war. As they did in most of the warring European states, academic social scientists-particularly historians and geographers-set to work in 1917 to provide data to support government positions both in advance of and at the peace talks.

The most significant of these academic-manned organizations in France was Le Comité d'études. Formed at the bequest of the Poincaré Government in

\footnotetext{
${ }^{66}$ For a theoretical discussion of the relationship between ontology and epistemology see Colin Hay, "Political Ontology," in The Oxford Handbook of Contextual Political Analysis, ed. Robert E. Goodin and Charles Tilly (New York: Oxford University Press, 2006), 76-96; For the defining work on epistemic community see Emmanuel Adler and Peter M. Haas, "Conclusion: Epistemic Communities and International Policy Coordination," International Organization 46 (1992): 373.
} 
1917, Le Comité was tasked to "Prepare the case for future negotiations, to bring together some of the most qualified for their work."67 Members were primarily drawn from the French university system, and the group was initially composed of twelve historians, three geographers and the chief of the Service géographique de l'armée. In early 1917, Le Comité worked quietly on the study of France's eastern and northeast borders, as well as on the question of regulating traffic on the Rhine River. But the group's work quickly expanded to include gathering geographical and political portfolios on much of Central Europe, and specifically the claims of nationhood that the French anticipated would be key disputed territories with the breakup of the Central Power empires. By 1919, the organization had grown to 26 experts and, like the American Inquiry, had expanded to include linguists and economists. ${ }^{68}$

Unlike the Inquiry, however, the work of Le Comité d'études was directed entirely by a minister of the state, under the charge of then-President Poincaré, which made the organization comparatively efficient in that it was focused on mostly clear political goals, such as the occupation of the Rhineland or the restoration of France to its 1814 boundaries. Perhaps because of the clear modus operandi of Le Comité, the group was remarkably effective at compiling mass amounts of data and distilling those into concisely condensed findings. Under the direction of Ernest Lavisse and Charles

\footnotetext{
${ }^{67}$ Emmanuelle de Martonne, Proceedings of the Study Committee, Alsace-Lorraine and the Border of North-East (Paris: Imprimerie Nationale, 1919), 450, 1.

${ }^{68}$ Emmannuelle Boulineau, « Un geographe traceur de frontières: Emmanuel de Martonne et la Roumanie, » L'Espace Geographique 4 (2001): 358-359.
} 
Benoist, both historians and moderate republicans, the group compiled two large but concise books for the French Foreign Office, covering a variety of historical and geographical examinations of French boundary claims, analyses of the minerals, languages and expected sovereign claims that were likely to emerge with the breakup of the empires in Central Europe. ${ }^{69}$

The American diplomatic corps and future Inquiry members knew of the French group well before the Inquiry had even been formed. And many European and American diplomats initially hoped that an equivalent technocratic body would emerge to direct opinion in the US. American intellectuals at first shared this hope, but many of the would-be-experts in the Inquiry soon became critical of Le Comité and of the sorts of people chosen to staff it. One early report to a still-nascent Inquiry executive (which then included Shotwell, Lippmann, Mezes and Bowman) cast doubt on the intellectual strength of key Comité members, and warned that political considerations unique to France-not least the ongoing need to balance national unity between that country's left and right-had been allowed to shape its personnel, focus and scope ${ }^{70}$ Publications released by Le Comité in 1918, which the Inquiry received through the Columbia Geographer and military officer Douglas Johnson, and later through Archibald Cary Coolidge (who served as a liaison until mid-1918), revealed the group's preoccupation with the long-disputed Alsace-Lorraine region and the left bank of the Rhine.

\footnotetext{
${ }^{69}$ Tbid.

${ }^{70}$ Major Douglas Johnson, "Report on Origin, Personnel, and Organization of the French Comite d'études, appointed to assemble data for the Peace Conference," Inquiry Files NARA (doc 270).
} 
As Johnson noted in one 1917 report, these topics had long captivated French strategic thinkers, and geographers with strong connections to the Service Géographie de l'Armée, the military geographical group that saw a spatially defendable border as the primary means of protecting France from further German invasions. With an executive manned by mostly conservative republicans, Le Comité d'études seemed, to Americans at least, to be a parochial and partisan group wasting many of the respectable social scientific minds at France's disposal, directed by an old guard of political ministers and military personnel who were too close to French President Raymond Poincaré for American comfort. ${ }^{71}$

While Johnson was impressed at the use of experts in France, the Americans (and many French) were unmoved by Le Comité's work. Despite a broad range of partisan representation on the group, it seemed too focused on Poincaré's vision of an expanded France after the war. American social scientists were ultimately right to doubt the purchase of an organization so conspicuously anchored to the military, and to the strategic goals of the Poincaré partisan factions, which proposed the annexation of territoryregardless of the local population's history and nationality-to fit strategic military boundaries designed with an eye to occupying of much of the Rhineland. With the election of Georges Clemenceau, the group, then led by Benoist, proposed a French territorial border that extended well past the Rhine. Their work was subsequently essentially ignored, its impressive

\footnotetext{
${ }^{71}$ Bowman to House, "Report on the Progress of the Inquiry," 1918 (series 3, box 3), House Papers.
} 
volumes of the historical and geographical foundations for an expanded France all but entirely dismissed. ${ }^{72}$

And yet, despite the fact that the Comite d'études was ignored as the peace talks grew closer, as Lowczyk notes, the very fact that the group was called together at all, bringing the work of French historical and geographical scientists to a new prominence in French policy, indicates a broader discursive shift whereby historical and cultural rationalization for territorial claims assumed a central spot in the state's imagination of itself and its relationship with other states. This was not lost on Isaiah Bowman, who remarked,

It is extremely interesting to find from Professor de Martonne's letters that the French Inquiry is plotting its statistical material by small administrative districts which is precisely the method that was adopted independently by this Inquiry after a thorough study of methods and of the questions which it has planned to be able to answer at the Peace Conference. It is a method requiring enormous volume of research and criticism as well as handling a very large body of administrative details-details which can only be handled by dividing the work among those of us located here. By following this method we are put in possession of details and facts of a high order of accuracy which enables us to face new questions with confidence. ${ }^{73}$

And it was not only French social scientists who shared this methodology for understanding the territorial and cultural divisions of nations. As other historians of Le Comite have noted, regardless of their political position on divisive territorial questions, French politicians almost universally used geographical, racial and linguistic histories to sanction their reading of the

\footnotetext{
${ }^{72}$ MacMillan, Paris 1919, 31-33; Olivier Lowczyk “" L'Historien et Le Diplomate en 1919,» 27-44.

${ }^{73}$ Bowman to House, "Report on the Progress of the Inquiry," House Papers; Olivier Lowczyk, "

L'Historien et Le Diplomate en 1919, » 33-44.
} 
French nation-state and its territorial holdings. ${ }^{74}$ In 1917 and into 1918, important differences of opinion lingered among experts over France's rightful boundaries following the war. Le Comité was a microcosm of these larger, conflicting political desires.

French conservative-republicans in the group generally favoured an expanded French state even beyond the boundaries of 1790 , not only allowing France to take on provinces it lost in the Franco-Prussian war, but also leaving the door open to additional acquisitions on the left bank of the Rhine and former German colonies, which could be used to secure indemnities for the massive losses suffered in the Great War. For the more leftist historians and geographers inside Le Comité, the contested AlsaceLorraine region, where the German state had systematically worked to eradicate French language and identity since 1870, the task of peace preparations was mostly focused on shoring up a strategic boundary in that region; questions of the Saar and left bank of the Rhine were left to negotiation. ${ }^{75}$

There was no question among those employed in Le Comité d'études of the importance that nationalism be reflected in territorial settlements. But the leftists, which included the historians Christian Pfister and Maurice Fallex, as well as Paul Vidal de la Blache-widely considered the founder of modern

\footnotetext{
${ }^{74}$ Boulineau, «Un Géographe Traceur De Frontières,» 358-369; For more on this also see Olivier Lowczyk, «Définir La Carte De l'Europe Après La Première Guerre Mondiale, Le Rôle Du Comité D'études) (Ph.D. diss., l'École pratique des hautes études, 2006).

${ }^{75}$ Boulineau, «Un Géographe Traceur De Frontières,» 358-360.
} 
French geography, and who died just before Johnson arrived in Paris-used an historical approach that seemed, at least to the visiting Johnson, to be able to balance the strategic concerns of the state with the cultural, linguistic, political and historical indicators of a population's chosen national allegiance in highly-contested regions like the Saar. ${ }^{76}$ Pfister, for example, told Johnson and subsequent American liaisons that he and his colleagues opposed annexationist conservative policies, noting that while France had a legitimate cultural and historical claim to Alsace-Lorraine as part of the nation, areas like Saar (where the majority of the population identified as German, but where coal deposits were strategically imperative to the industrial prosperity of France), would have to achieve a balance between cultural-national identity and territorial and economic security. ${ }^{77}$ It is not a coincidence that Johnson, as a geographer and liberal, gravitated to this marginalized group in Le Comité. He admired Pfister as a moderate, and passed along his belief that calls for annexation of the left bank of the Rhine were "full of insanity."78 Pfister's analysis measured the cultural, historical and linguistic make-up of a population against assuring sovereignty through territorial and economic

\footnotetext{
${ }^{76}$ Geoffrey J. Martin, All Possible Worlds: A History of Geographical Ideas, (New York: Oxford University Press, 2005), 194.

${ }_{77}$ Olivier Lowczyk « L'historien et le diplomate en 1919. » Using the brief and little known 1814 Paris Treaty as their touchstone, they imagined a France that would have access to key mineral deposits in part of the Saar region, but would exchange control over the northern part of Saar to the Rhine for a more linear border in Alsace Lorraine.

${ }_{78}$ Johnson, "Report on the Origin..."
} 
security, and in this moderation it seemed the most reasonable way to set the boundaries of any nation-state in Europe. ${ }^{79}$

Le Comité highlights a broad and noticeable shift in the articulationand articulators -of the proper confines of the nation-state. By the time preliminary peace talks had opened in Paris, the French had laid aside much of the work of Le Comité, but were nevertheless careful to strategically emphasize the empirical, social scientific bases for nationality in their proposals for peace. For example, in making the case for France's right to the Saar and left bank of the Rhine, Clemenceau's representatives in Paris deemphasized the recent history of that region and argued that the French had an ancient connection to Saar. It is not a question of whether such a claim could be substantiated; it was that it was implicitly advanced as the basis upon which any claim had to forge its legitimacy. As Clemenceau would discover in talks with Wilson, however, the American delegates had little appetite for histories of events that would "readjust Europe on the basis of conditions that existed in such a remote period." And so, the French appealed to the security of their own nation, arguing that the defensible natural geographical border of the Rhine was the only way to assure that war would not again threaten their sovereignty. When still no compromise could be found, the matter was deferred to experts. ${ }^{80}$

\footnotetext{
${ }^{79}$ Lowczyk, « L'Historien Et Le Diplomate en 1919 » 29.

${ }^{80}$ MacMillan, Paris 1919, 199.
} 
The British assemblage of experts, meanwhile, was similar to France and other European nations in some important respects. First, as one British historian as argued, "depressingly few scientists resisted the call to arms in 1914," and even those who did, such as Bertrand Russell, were subjected to merciless campaigns of vilification and abuse. Expert social scientists rarely needed to be forced into service for the state; most jumped at the opportunity to become more central to state policy capacities. ${ }^{81}$ In a nation where the political class had long been consciously at the vanguard of social scientific institutions, Britain's professional social science associations, such as the Royal Geographical Society, loaned resources to the state while other professionals worked directly under its apparatus. ${ }^{82}$ Much of this work took place within the Foreign Office itself, as experts in history, geography and anthropology composed handbooks on the economic, territorial, and strategic questions anticipated in peace talks when hostilities finally ended. ${ }^{83}$

The British commission was a mix of social scientists from universities across the country-though most substantially drawn from Oxbridge institutions-who mustered the map-making capacities of the military and information from other government agencies as needed. While Britain did not have the same immediate concern with protecting its own territorial

\footnotetext{
${ }^{81}$ For work on the use of professional geographical and cartographic resources by the British state see, M. Heffernan, "Geography, Cartography and Military Intelligence: The Royal Geographical Society and the First World War," Transactions of the Institute of British Geographers 21 (1996): 504-533.

${ }^{82}$ For more on the long interconnection between Britain's political elite and social scientific work there see Abrams, The Origins of British Sociology; Poovey, A History of the Modern Fact; Gabay, "The Political Origins of Social Science."

${ }^{83}$ Heffernan, "Geography, Cartography and Military Intelligence," 504-515.
} 
boundaries from a rival power, it did share France's interest in the fate of German colonial lands in a post-war international system. The British also did not know the extent of the work going on in France, but Sir William Wiseman (the British liaison sent to Washington in 1917, who had close ties to Lowell and the LEP) was aware that Inquiry members and the broader professional middle class was overwhelmingly pro-British. Wiseman played to this bias while also capitalizing on American concerns with self-determination. He assured them that Britain's interest in colonial holdings could not be interpreted as on par with German imperialism. To this end, Wiseman gave George Louis Beer, a close associate of Shotwell and the Inquiry's anthropological expert on German colonies, access to British expert reports that made a case for the importance of continued British rule in many of the colonies, and floated the case for transferring German colonies to British rule on the basis that the latter's form of governing these far-off lands was much less violent and effective. ${ }^{84}$ In courting anglophiles like Beer, Wiseman knew that protecting British colonies and influencing the shape of international organization after the war would not only mean close relations with Colonel House, but also nurturing a shared purpose with "this organization of his" by making sure the Inquiry stayed interpersonally and ideologically connected to the experts in Britain. ${ }^{85}$

\footnotetext{
${ }^{84}$ Gelfand, The Inquiry, 120.

${ }^{85}$ Ibid. 19. For examples of British attempts to make this distinction in the British press see, Thoughts on German Colonies. A J Balfour, July 1918; "Future Of German Colonies. Wishes Of The Natives, Preference For British Rule" The Times, 12 December 1918, 7; "Why German Colonies Must Be Kept:
} 
Though both the French committee and the British experts visibly served under agencies or departments of their states, the British experts and the Foreign Office there were much less concerned with treating expert opinion as policy recommendations. Instead, the former were used to collect data, much as the Inquiry did, and were instructed to compile it into recommendations that would be vetted and revised by political officials. They were, perhaps more than the French and definitely more than the Americans, so intertwined with the workings of the Foreign Office and other government bureaus that it is difficult and misleading to separate out which of the eventual recommendations came from "experts" and which came from inside formal government channels. What is clear, however, is that as early as 1917 , British data, which the Americans had access to, reflected Wilson's emphasis on selfdetermination. The British were careful always to make it the foundational "principle of a readjustment of national boundaries." ${ }^{86}$ As with the French and Americans, the British application of self-determination was restricted, assumed to include only a select community of what many considered matured nationalities-countries already assumed capable of selfgovernment. As E.H. Carr, the historian and then Clerk in the Foreign Office, later noted of the British position on self-determination,

Native Appeals For British rule" The Times, 11 December 1918, 12; Mr. Walter Long, "Mr. Long on German Colonies. No Restoration," The Times, 27 September 1918, page 8.

${ }^{86}$ David Lloyd George, The Truth About the Peace Treaties, Vol. 1 (London: Victor Gollanca Ltd, 1938),1, 31. For more on Lloyd Georges use of self-determination before Wilsonianism turned more sharply towards it as a precept see, Erez Manela, The Wilsonian Moment: Self-Determination and the International Origins of Anticolonial Nationalism, 42. 
The whole thing was infinitely complicated, first, by the fact that neither the British and the Americans had any notion of applying it [self-determination] to countries outside Europe where their own interests lay... and they [the British] did not really believe in self-determination as such, but simply the right of small nations; and this was really a hangover from the old balance of power theory supporting the weak against the strong, taking the form of the liberal doctrine that God is on the side of the small battalions. $^{87}$

Many historians have since echoed Carr's observations about the problems that came with making self-determination the core of a new international order at the Paris talks. These are important critiques because they present the tensions between the ideal of self-determination and its problematic application in a particularly racist and prejudiced environment, where countries could be discriminated against but nonetheless forced to participate. Yet, unless the concept is assumed to have sprung up out of Wilson's thought alone, there is still the untold story of how it became a plausible and reasonable concept. That story hinges on a larger, transnational network of social scientists who spoke in an increasingly common, bourgeois language of internationalism that made it possible to imagine a global order built around territorialized nation-states that reflected the will of their people rather than their governing elite.

The Inquiry, Le Comité d'études, and the British Commission, not to mention a multitude of social scientists from Eastern Europe, Belgium, the

\footnotetext{
${ }^{87}$ Jonathan Haslam, The Vices of Integrity: E.H. Carr 1892-1982, 1st ed. (New York: Verso Pres, 1999),
} 26. 
Netherlands, Switzerland, Scandinavia and even Luxembourg who fed partisan reports and position papers to their colleagues working in commissions around the world, offer a starting point for the overlooked story of a burgeoning international social scientific community built around a very particular rationality, in the closing days of the Great War. Leaving aside debates about differences in strategic focus, and momentarily bracketing the important differences in the relationship between social scientists and the mechanisms of individual state formations in arriving at peace proposals, the three commissions of experts reveal an important epistemic consensus around how to define the nation-state, and who was best suited to define it. It was no coincidence that, as with the already established liberal democracies, university-employed history or geography experts represented a substantial number of those "new" nations at the peace talks lobbying for territorial statehood: Jovan Cvijic from the University of Belgrade was a prominent member of the "Yugoslav" delegation, and Eugeniusz Romer of the University of Lwòw, was central to the Polish delegation. ${ }^{88}$ There were so many distinguished scholars at the Peace Conference that "Senior British geographers were understandably fearful" they "would overwhelm the efforts made by British geographical agencies." 89 But the case for statehood went beyond simply employing social scientists. As the relationship between the Allied committees revealed, politicians and experts believed social scientific

\footnotetext{
${ }^{88}$ M. Heffeman, "Geography, Cartography and Military Intelligence," 521.

${ }^{89}$ Ibid.
} 
study could make some definitive sense out of the mushy concept of selfdetermination by balancing a people's claims for statehood or territorial sovereignty against data and analysis that only discerning scientific minds could interpret.

In this way, the expert commissions constituted what John Ruggie and Peter Haas have called an epistemic community:

a network of professionals with recognized expertise and competence in a particular domain and an authoritative claim to policy-relevant knowledge within that domain or issue area. Although an epistemic community may consist of professionals from a variety of disciplines and backgrounds, they have (1) a shared set of normative and principled beliefs...; (2) shared casual beliefs, derived from their analysis of practices leading or contributing to a central set of problems in their domain...; (3) shared notions of validity-that is, intersubjective, internally defined criteria for weighing and validating knowledge in the domain of their expertise; and (4) a common policy enterprise-a set of common practices associated with a set of problems to which their professional competence is directed. ${ }^{90}$

The significance of this transnational epistemic community was not lost on Inquiry members. On one level, participation quelled objections that the use of experts in history, economics, anthropology and geography constituted an attempt to rival or challenge the power of the State Department. It put the organization beyond reproach by elevating its knowledge above the sphere of local-national politics and interests that the State Department, by its nature, worked within. "The case for the Inquiry," Shotwell argued after the war, "passes beyond argument when we find that the same kind of organization

\footnotetext{
${ }^{90}$ Peter M. Haas, "Introduction: Epistemic Communities and International Policy Coordination," International Organization 46 (1992), 1-6.
} 
was established by the governments of Great Britain and France and that when Germany began to face a peace that would not be dictated by it...it similarly drew on specialists," first from inside government, but later, with more frequency, from outside. ${ }^{91}$

While the British and French committees remained deeply suspicious of each other (despite, as Lawrence Gelfand has shown, each being mostly oblivious to the other's political focus and work), the American social scientists had high hopes for American-led cooperation, particularly if it could capitalize on the community of experts preparing for peace across the western world. ${ }^{92}$ Johnson almost immediately recognized the benefits of transnational reach. After his visit to the Inquiry's sister organizations across the Atlantic, he became the most vocal advocate for institutionalizing the loose network of experts into a formal center or "bureau." Early in 1918, he proposed such a centre where British, French and other nations' expertsAllied and Central powers alike-could jointly consider data gathered by various states. Johnson's proposal was not built on some abstract notion of academics facilitating diplomatic dialogue. Rather, he imagined a research hub that would, through intense empirical scrutiny, formalize and institutionalize "the distribution of nationalities," such that "where divergence of opinion as to the facts existed," experts would come together in "critically studying the value of the authorities used and the methods of interpreting

\footnotetext{
${ }^{91}$ Shotwell, At the Paris Peace Conference, 14.

${ }^{92}$ Gelfand, The Inquiry, 125-130.
} 
statistics employed by each investigator and endeavour to reach substantial agreement as to which authorities and interpretations seemed most worthy of confidence." Johnson believed that, despite their national differences, experts in belligerent nations shared an epistemological commitment to the scientific study of societies, which could rationally and objectively deliver nations to agreed-upon norms arrived at through a scientific standardization of data, statistics, maps and figures. Such objectivity would be the means by which the rancor of war and national jealousies could be overcome. As Gelfand notes, Johnson's proposal for a committee of experts received a sympathetic ear from leading French officials in le Comité, but they were quick to note that they "were unsure that support would be forthcoming from their superiors." 94

The idea that political interest would not allow for such a committee to form only injected Johnson's mission with a deeper sense of scientific righteousness and urgency. He understood that his European colleagues faced unique political and moral forces in their work, not least a virulent nationalism that allowed that state to significantly affect the focus and direction of social scientific analysis, effectively, for Johnson, distorting their work to reflect political concerns. But, rather than seeing the state as an equally influential and inseparable force in the Inquiry's work, Johnson

\footnotetext{
93 Johnson to Inquiry, n.d. (file 33, no. 9) "Suggestions for a Plan for the Closer Cooperation of the Several Commissions engaged in Assembling Data for the Use of the Peace Conference," House Papers.

${ }^{94}$ Gelfand, The Inquiry, 130.
} 
believed that "the Inquiry possessed a unique position." The same faith that made so many Americans believe a new order was possible made Johnson and many of his colleagues believe that the American peace principles were rooted to America's exceptional access to the criteria for defining states criteria that were apart from political and moral influence. The early historian of Le Comité, Dimitri Kitsikis, argued that while actions "recommended by the experts often tended to support the national interests and principles of the govermments employing their services," ${ }^{96}$ there were some intellectuals at the Peace Conference that seemed able to imagine a larger picture in international relations. Perhaps Johnson, with his faith in the possibility of a scientific peace, would be recognized today as one such expert. More than any other member of the Inquiry, Johnson was remarkable for his principled, almost positivistic faith in the possibility of a truly scientific peace, not least his controversial and antagonistic stance against Wilson on Yugoslavia's right to the Fiume region. ${ }^{97}$ For Johnson, the network of experts he had visited around the world revealed that while there were differences in just how

\footnotetext{
${ }^{95}$ Johnson to Inquiry, "Suggestions for a Plan for the Closer Cooperation..."

${ }^{96}$ Lawrence Gelfand, "Review of Le Role Des Experts a La Conference De La Paix De 1919: Gestation D'une Technocratie En Politique Internationale by Dimitri Kitsikis," Journal of Modern History 45 (1973): 697-699.

${ }^{97}$ Smith, American Empire, 165. Johnson took this stance with mostly geographical colleagues (other than Day and Seymour), arguing that if the Fiume were given to Italy to meet one of that nation's demands the US would undo its own war aims and the legitimacy of the League by compromising to achieve both. "The belligerent nations including Italy, agreed to make peace on the president's principles," a letter that Johnson, Bowman and four other colleagues sent to Wilson argued. If "Italy gets nominal sovereignty over Fiume as the price of supporting the League of Nations," the letter continued, "she has brought the League down to her level." For more see, Letter from Bowman, Lunt, Day, Johnson, Seymour, to Wilson, April 17, 1919, Wilson MSS, Series VIII-A, Library of Congress, Manuscripts Division; and see Gelfand, Inquiry, 329.
} 
independent the various allied experts were from their states, states were bound through a nongovernmental class of experts.

And yet Johnson's attempts failed. This failure by no means indicates a weakening of the authority of social science or the community of practitioners around peace talk preparations. Rather, I argue it shows that American social scientists were subject, despite their feelings of disinterested objectivity, to the same intensity of nationalism and of national interests that they worried were poisoning the objectivism their global counterparts. For the US social scientists, state-government influence on European social scientists was evident in their institutional alignments, and served as a particularly powerful way to juxtapose America's own state form and governmental foundations. They understood that the institutional formalization of their epistemic community would expose America's supposedly altruistic liberal war aims to reactionary forces in Europe, in turn exposing their social sciences to criticism for being connected to conservative interests. ${ }^{98}$ As Gelfand put it, the ambivalence about an international social scientific committee was likely rooted to two fears: first, that cooperation might be read as "a virtual peace conference before the constituted peace conference"; and second, that "government officials might find it impossible to divest themselves of their official status" in the name of cooperation. ${ }^{99}$ These possibilities threatened the Inquiry's claims to authority and legitimacy, even as the latter was in some

\footnotetext{
${ }^{98}$ Ninkovich, The Wilsonian Century, 24-25.

${ }^{99}$ Gelfand, The Inquiry, 45.
} 
ways enhanced by participation in a larger, transnational epistemic community. Thus, American exceptionalism needed to be properly calibrated in order to impress upon those involved that American social scientists had a special claim to be the leading force in peace preparations.

\section{Self-Determination and Scientistic foundations of American}

\section{Magnanimity}

As I have already shown, House and Wilson were deliberate about placing the Inquiry and later the Commission to Negotiate Peace structurally beyond the reach of government divisions charged with foreign policy, particularly and most notably the State Department. Wilson's immediate circle of advisors did complain that the State Department, as well as some of the figures that had been proposed as candidates for the Inquiry's Executive, lacked the right kind of analytical mind or were too politically reactionary. Wilson voiced these same concerns when he suggested that the State Department could not handle a new peace organization because, in his words, men like Lansing were "not conducive to a broad outlook as they are mostly society folk and reactionaries." ${ }^{100}$ The only way an organization could work with the diplomatic channels, yet visibly buck European-style diplomacy and buttress the exceptionalism of America's new internationalism would be to recruit experts

\footnotetext{
${ }^{100}$ Wilson to House, 9 September 1917 (Series 3), House Papers. Also cited in Gelfand, The Inquiry, 29. Gelfand treats this statement as little more than an indication of Wilson's personal dislike of Lansing.
} 
"outside" the functions of the state and its society folk, but still ideologically onside with the operating ideal of "states interests."

House and the Inquiry executive found such authority in the emerging "students of international affairs drawn from the faculties of the universities, whose duty it would be to study the political, economic, legal, and historical elements of the problems which would have to be faced in the treaty of peace." Shotwell's recollection continued: "Technically [this group] was connected with the State Department but really it was to be the President's personal staff under Colonel House's direction."101 These students were experts without political posts, and had an authority that was distinctly not experienced, something that Mezes and the other Inquiry men knew House and Wilson valued against the social and political conservatism they associated with Lansing. "[Lansing's] feeling seemed to be that our Inquiry force was inexperienced in practical dealing with foreign questions, which is true, and that he had better men on his force, which I doubt," Mezes wrote to House. ${ }^{102}$ This sense of battling authorities, of creating a body beyond the political establishment, echoed Charles Seymour's earlier assessment of the Inquiry as an important passing point for data that remained distinctly detached from other government bureaus:

Only the best experts we can get and the best data will enable us successfully to fight the forces of disunity among the Allies. This is the great weapon of the Central Powers and it will

\footnotetext{
101 Shotwell, At The Paris Peace Conference, 2.

${ }^{102}$ Mezes to House, 26 October 1918 (series 1, box 2, folder 127), Inquiry Papers Yale.
} 
remain powerful even if we should carry the defeat of Germany to the point of annihilation as a military power...The government bureaus, and other agencies, are doing their part of the work with complete cordiality. They recognize the Inquiry as the authorized peace organization and are wholly in our hands, doing a vast amount of work according to plans framed by Prof. Young and myself. It is only necessary to do our part to keep their respect and good-will [sic]. Our organization chart will show that we have pulled in all of these bureaus. ${ }^{103}$

This inversion of authority, which Seymour shared with others, was not a delusion of grandeur. It was a result of a growing belief within Wilsonian circles that a scientific spirit was simply better able to grasp the social complexity of the war and the peace.

Integral to positioning America and its social scientists in this leadership role was the ideal that American's concern with instituting popular sovereignty, increasingly dependent on language of "self-determination", made the US a magnanimous power among otherwise imperial states. While self-determination had not been a big part of the initial justification of America's entry into the war, nor was it central to Wilson's first statements of America's goals for peace, it became increasingly important as the peace conference approached. Importantly, Wilson's only explicit statement of war aims and the most influential one as such by any of the belligerents of the war, was the Fourteen Points address-read to a joint session of Congress on 8 January 1918-ten months before the armistice with Germany. The sweeping

\footnotetext{
${ }^{103}$ Seymour to House, 30 August 1918 (series 1, box 2, folder 116), Inquiry Papers Yale.
} 
document proposed to the American people and its allies that the US was fighting for, and could only work to broker a peace that acknowledged, "a free, open-minded, and absolutely impartial adjustment of all colonial claims, based upon a strict observance of the principle that in determining all such questions of sovereignty the interests of the populations concerned must have equal weight with the equitable claims of the government whose title is to be determined." 104 This call to balance the will of a population with governmental claims of sovereignty echoed Wilson's "peace without victory" speech of 1917, where he had earlier outlined in greater detail a vision for a world of self-governed states composed of consenting subjects:

Mankind is looking now for freedom of life, not for equipoises of power ... And there is a deeper thing involved than even equality of right among organized nations. No peace can last, or ought to last, which does not recognize and accept the principle that governments derive all their just powers from the consent of the governed, and that no right anywhere exists to hand peoples about from sovereignty to sovereignty as if they were property ... I speak of this, not because of any desire to exalt an abstract political principle which has always been held very dear by those who have sought to build up liberty in America but for the same reason that I have spoken of the other conditions of peace which seem to me clearly indispensable-because I wish frankly to uncover realities. Any peace which does not recognize and accept this principle will inevitably be upset. It will not rest upon the affections or the convictions of mankind. The ferment of spirit of whole populations will fight subtly and constantly against it, and all the world will sympathize. The world can be at peace only if its life is stable, and there can be no stability where the

\footnotetext{
${ }^{104}$ Wilson, "An Address to a Joint Session of Congress" (hereafter Fourteen Points), 8 January 1918, $P W W$ 45: 535. Emphasis added.
} 
will is in rebellion, where there is not tranquility of spirit and a sense of justice, of freedom, and of right. ${ }^{105}$

The idea that collective security could be built on a plurality of popularly governed nations excited nationalists from various political-ideological positions around the world. Of course, other politician including Lloyd George and V.I. Lenin, had proposed variable peace settlements around the ideal of self-determination before Wilson made it a pillar of the American peace plan. ${ }^{106}$ As Arno J. Mayer famously argued of Wilson's adoption of selfdetermination in late 1918, Wilson's adoption must be understood, at least in part, as a response to the threat posed by similar rhetoric coming from Bolshevik-controlled Russia, as part of a battle for the European left." ${ }^{107}$ It was through the "Bolshevik insistence at Brest-Litovsk," Mayer argued, "that selfdetermination became a 'dominant interest' for the diplomacy of the war," making Wilson's task in the lead-up to and during Versailles the neutralization of Bolshevism by appealing to the nationalist and anti-imperialist sentiment already capitalized on by Russia's communists. ${ }^{108}$ Despite his slow and relatively late adoption of the principle, Wilson's statements on popular democracy and self-government were taken as an endorsement of "selfdetermination." And, when coupled with America's growing power and appeal, many nationalists outside of the US hoped this new ideal would

\footnotetext{
105 "An Address to the Senate," 22 January 1917, PPW, vol. 47: 536-539.

${ }^{106}$ Erez Manela, The Wilsonian Moment, 42.

${ }^{107}$ Borislav Chernev, "The Brest-Litovsk Moment: Self-Determination Discourse in Eastern Europe Before Wilsonianism," Diplomacy \& Statecraft 22 (2011): 369-387.

${ }^{108}$ Arno J. Mayer, Wilson Vs. Lenin: Political Origins of the New Diplomacy, 1918-1919 (New York:

World Publishing, 1969), 293-312.
} 
translate into a fundamental rethinking of who and how one was recognized as a sovereign nation-state by the international community. ${ }^{109}$

Ironically, given America's foundational commitment to government by the consent of the governed, the ideal of a world composed of selfdetermined nation-states was much less well received at home. Granted, it appealed to many in America's elite because it fed into its broad belief in American exceptionalism. Still, self-determination-particularly the assumption that its culmination rested in liberal nation-states-was criticized within liberal and conservative circles as excessively idealistic because of its failure to grasp the realities of power in a well-entrenched European system. ${ }^{110}$ Within his own administration, even, Wilson faced doubts over whether or not self-determination was a viable criterion on which to arbitrate sovereignty. Lansing privately stewed: "When the president talks of 'selfdetermination' what unity has he in mind? Does he mean a race, a territorial area, or a community? ... It will raise hopes which can never be realized. It will, I fear, cost thousands of lives. In the end it is bound to be discredited, to be called the dream of an idealist who failed to realize the danger until it was too late to check those who attempt to put the principle into force."111

\footnotetext{
${ }^{109}$ MacMillan, Paris 1919, 13-16.

${ }^{110}$ Knock, To End All Wars, 145-150.

${ }^{111}$ Robert Lansing, The Peace Negotiations: A Personal Narrative (Boston: Houghton Mifflin, 1921), 97 98. Much has been made of Lansing's take on self-determination and many have used it as a sign that there was internal dissent over Wilson's "idealistic" approach to foreign policy. For other exploration of the American political debate over self-determination see MacMillan, Paris 1919, 11; Manela, The Wilsonian Moment, 24-25.
} 
To Lansing's credit, there is still little evidence to suggest that the president grasped or even contemplated the ambiguities of accepting the right of self-determination for nations like Poland while rejecting it for nations like Ireland. ${ }^{112}$ This is to say nothing of those aspirant national movements outside Europe, in colonial regions like Africa and Asia where sovereignty was not seen as a strategic and political benefit to the Entente powers. As Lansing noted, the messiness of a concept like self-determination generated as many questions as it answered: what constituted a nation? What criteria defined the nation-ethnicity, language, civic institutions, race, religion? Could nations be multi-ethnic? Should they be? Was ethnicity the only marker of nationalism, or could values (shared in a constitution or a church) offer the necessary glue to hold a group together?

A beleaguered Wilson would eventually concede the complexity of the term, telling Congress by the end of 1919, "When I gave utterance to those words [that all nations had a right to self-determination], I said them without knowledge that [certain] nationalities existed, which are coming to us day after day." 113 The use of self-determination as a foundation for international order may have aroused faith in American exceptionalism, feeding a belief that popular democracy could be arrived at through the same process of organic national self-realization that Americans had wrestled with, and which

\footnotetext{
112 MacMillan, Paris 1919, 11-12.

${ }^{113}$ Ibid., 12-13. Wilson was far from the only politician flirting with the term. Both Lloyd George and V.I. Lenin, had proposed a peace settlement around the principle of self-determination before Wilson made it a pillar of his peace plan. See Manela, The Wilsonian Moment, 42.
} 
many imagined as the bedrock of America's pluralist society and political

culture. But the unintended consequence of exciting and legitimating nationalistic sentiments in regions under colonial rule-such as Ireland, Vietnam, China or Egypt-threatened America's own strategic and hegemonic ambitions at the peace talks. ${ }^{114}$ In this respect, histories of Wilsonianism are right to point to obvious flaws in his logic of nation building, his ambiguous application of self-determination to nations across the world, and his focus on European claims over and above all others. ${ }^{115}$

For it to work as an organizing principle for redrawing the European map, national identities had to already exist, but their geopolitical form had to be translated into real territorial boundaries in order to be politically recognized by the international community. Such a system of definition and recognition, it was hoped, would change the way geopolitical units related to one another, relying not on the state as defined by a ruling sovereign, but on liberal self-governing subjects who possessed a cosmopolitan consciousness

\footnotetext{
${ }^{114}$ For more on the spread of nationalism, see Manella, The Wilsonian Moment, 55-136.

${ }^{115}$ For example, as Manella notes, the questions of why colonial holdings such as Egypt, where nationalism was already excited, did not receive statehood, while Poland assumed formal statehood from the outset has haunted historical assessments of Wilsonianism and international self-determination. Sovereign nationstatehood for those on the European continent and those claiming nation status in colonies or imperial holdings of the world meant two very different things for the conferees and commissioners at Versailles. The established great national powers on the continent felt the clash most acutely around questions of continental territory and resources. Here, "national interests" seemed both complimented and contradicted by the American international vision of a peace based on national self-determination and "peace without victory." Basing a peace on nationality and the interests of nations assured France the recovery of territory it had lost to Prussia decades earlier in the Franco-Prussian War. And yet, by the same token, it contradicted the French hope to see the Rhineland of Germany parceled off to the victors or created as a distinct Saxony state to buffer between the two Great Powers; effectively crushing the regionalist selfidentity of many in the Alsace-Lorraine region. The same tension emerged for the British, though on a less immediate scale, with the assurances that self-determination gave for the reinstatement of Belgium. While Belgium provided and important ally and buffer between Britain and the continental national powers, selfdetermination presented a possible problem-and certainly an irritant for many American-Irish and liberals - with "the Irish Problem" of colonial and imperial control over Ireland.
} 
that allowed them to check the particular and often provincial power of nationstates.

Self-determination, however, produced a double bind for Americans. On the one hand, Wilson's usage of self-determination was meant to communicate that liberal internationalism had the capacity to break with the past imperial system that had, in Wilson's account at least, culminated in the Great War. But, on the other hand, Wilson's and most others' ideal of the liberal, self-governing subject was still seeply moored to pre-existing racialist and hierarchical thinking that still placed white, western, liberalized peoples at the apex of historical development. Wilson may not have deeply contemplated the consequences of this logic for those colonial regions, and sub-national identities within nations-states that were left in limbo by an uncertain peace. But the team of researchers that accompanied him to Versailles certainly gave thought to how to negotiate this bind. And they were quick to point out their own centrality, as social scientists rather than statesmen and lawyers, in rendering visible the criteria for self-determination, and in judging the merits of those who claimed nationhood status.

Among those was Charles Homer Haskins, a medieival historian at Harvard and an adviser to Wilson at Paris. The two had met at Johns Hopkins, and remained friends. At Paris, Haskins actually contended that "the principle of nationality" was given more weight at the peace talks within "its broader 
historic sense, than to economic or strategic considerations."116 Haskin's choice to emphasize the historical dimension of nationality was not simply professional conceit. Rather it speaks to a growing consensus among social scientists across the Western world, reinforced by the applications of fledgling nations using the same methods employed by the Great Powers, that nationhood was central to international order. The archives of the American Commission to Negotiate Peace and the personal documents of those close to the Commission reveal dozens of aspirant nations across Europe, Africa and Asia, motivated by their belief that the US held the fate and contours of their sovereign futures in its hands. They peppered contacts close to the commission and the Inquiry with studies, reports, proposals and data employing by then common historical, ethnographic, economic and geographic methods, and framed using the Wilsonian general principle of self-determination. ${ }^{117}$ All this certainly complicated the peace process for the great powers, but it had wider implications precisely because it was an implicit recognition that the transnational practices of the social sciences provided the mechanisms by which nationhood could be quantified and legitimized. In this sense, the politics of nationalism and the epistemological authority of the social sciences became mutually constitutive. For the American delegation, in particular, it gave the social sciences a way to thrust

\footnotetext{
${ }^{116}$ Charles Haskins, Some Problems of the Peace Conference (Cambridge: Harvard University Press, 1922), 19.

${ }^{117}$ The record groups containing these reports at the NARA in College Park and Yale University have often been cited in specific studies focused on particular nations. For an example of a work that touches on these reports see, J. W. Dafoe, "Canada and the Peace Conference of 1919," Canadian Historical Review 24 (1943): 233-248.
} 
their methods and professional credentials to the core of what people came to understand as modern internationalism.

\section{The Preponderance of the Social International Experts from the Inquiry at Paris}

The lack of emphasis on "economic or strategic considerations" that caught Haskins's attention became especially pronounced, and controversial, with the revelation of The League of Nations Covenant. The Covenant was a piece in the final draft of the Versailles Treaty that bound all signors to a "collective security agreement" guaranteeing the territorial and political independence of all members. By May 1919, the draft of the Treaty containing the Covenant was delivered to German delegates, who had been left out of the initial talks because of domestic political pressures in the allied nations. The Germans, buttressed by their own expert social scientists, returned objections and counterproposals to what many on both sides of the talks judged to be unfair peace terms in the Covenant. Max Weber, the much-respected Germanliberal sociologist, had somewhat gradually come to oppose the war, and he joined like-minded academics in condemning the Allies' failure to acknowledge the shared guilt and imperialism of both sides of the conflict. "We do not deny the responsibility of those in power before and during the war," he argued, "but we believe that all the great powers of Europe who were at war are guilty."118 This sentiment was shared by a number of prominent academics in Britain and the US, though some, like Giddings,

\footnotetext{
${ }^{118}$ MacMillan, Paris 1919, 466.
} 
maintained that a peace had to ensure that the world's liberal democracies avoided becoming entangled with the corrupting force of autocratic states like Germany. ${ }^{119}$

But many others close to the peace-planning groups of the Great Powers understood that the division drawn between autocratic and democratic nation-states did not neatly transpose onto the wartime division between the entente and the central powers. Rather, their 'truly scientific' approach made room for the assumption that all nations had the potential to retreat back to the petty, un-transparent and imperial diplomacy that had caused the Great War in the first place. One of those working with the U.K. government, the economist and then high-ranking British Treasury Board bureaucrat John Maynard Keynes, joined a chorus of influential international experts expressing dismay over the treaty. Like his British colleague Carr, Keynes focused his disappointment with the treaty on what he saw as Wilson's failure to rely on the advice of his experts throughout the talks. ${ }^{120}$ "It was commonly believed," Keynes later argued in his now famous Economic Consequences of the Peace,

that the President had thought out, with the aid of a large body of advisers, a comprehensive scheme not only for the League of Nations, but for the embodiment of the Fourteen Points in an Actual Treaty of Peace. He had no plan, no scheme, no constructive ideas whatever ... He could not frame their concrete application to the actual state of Europe ... He did not remedy these defects by seeking aid

\footnotetext{
${ }^{119}$ Franklin H. Giddings, "The Bases of a Just and Enduring Peace," The Annals of the American Academy of Political and Social Science 72 (1917): 83-88.

${ }^{120}$ Haslam, The Vices of Integrity, 29.
} 
from the collective wisdom of his lieutenants. ${ }^{121}$

For many of the non-American experts at the talks in Paris, the experience revealed that the League, and the compromises that Wilson seemed willing to make to secure it, did not represent the break with secret diplomacy that had been the pox of imperial state diplomacy. Far from a symbol of the success of Wilson's much-vaunted "new diplomacy," the way the proposed League Covenant was presented to Germany, and plans to exclude it from the organization, appeared a betrayal of the liberal principles underpinning a more rational, broad-based sovereign order. American experts, however, were ambivalent about the treaty; one account later recalled Shotwell arguing that, "there was more questioning of the 'imposed treaty' by members of the British delegation than by the Americans." 122

Within the American delegation, disappointment appeared to revolve around the unseemly settlement of territorial boundaries that reflected few or none of the ideas they hoped would organize the entire system. As information of wartime secret treaties continued to leak out in 1919, and Wilson appeared to buckle under French and Italian demands for territorial adjustments that were clearly contraventions of self-determination, some complained that Wilson had abandoned the scientistic principles he lauded to his advisors on the George Washington. Shotwell believed that to work on "the final text in the absence of Germany was to lose the perspective of Europe as

\footnotetext{
${ }^{121}$ John Maynard Keynes, The Economic Consequences of the Peace [1919](New York: Skyhorse Publishing, 2007), 24.

${ }^{122}$ Cited in Dafoe, "Canada and the Peace Conference of 1919," 243.
} 
a whole because in the very nature of things the facts, even if established, were seen only from one side." 123 But, like Shotwell, many of the Inquiry experts seemed to also think it inevitable that some compromise would be made of the principles of open diplomacy. Charles Seymour, a key figure in preparing data for the peace talks, put it this way:

These men were by no means all-powerful. There is a price to be paid for democratic diplomacy. Had they been as wise as Nestor they were still responsible to the people back home. It was the paradox of this war waged in the cause of democracy that the very triumph of democracy gave to chauvinistic public opinion a power to determine policies which were destined to sow the seeds of another war, waged again to save democracy ... The Peace Conference, representing the democracies, reflected the mind of the age; it could not rise measurably above its source. That mind was dominated by reactionary nostalgia and a traditional nationalism. ${ }^{124}$

Thus, while some American experts were much more critical, Shotwell, Seymour, Isaiah Bowman and many of the other Inquiry experts acted, in part, as apologists. Even as some attacked Wilsonianism as a failure for not meeting its own professed principles, these academics, Gelfand argues, clung "tenaciously and inflexibly to Wilsonian principles in the face of the new power structures rising out of the war."125

Their clinging to those new power structures reveals just how invested the men of the Inquiry were, especially those who travelled to Paris, in Wilson's promise of a world of self-determined nations. It suggests that their

\footnotetext{
${ }^{123}$ Ibid.

${ }^{124}$ Charles Seymour, Geography, Justice, and Politics at the Paris Conference of 1919 (New York: The American Geographical Society, 1951), 13.

${ }^{125}$ Gelfand, The Inquiry, 328.
} 
identity, as what Jameson called "scientific citizen of the world", hinged on their role of furnishing this principle with an empirical underpinning. ${ }^{126}$ Faced as they were by the Bolshevik treaties appealing directly to the people vis-àvis the principle of self-determination, the American foreign policy establishment understood that the liberal democracies of the Allied powers would have to not only deal with impending territorial disputes, but also contend with the underlying social unrest and growing discontent with the system that had led to war, and which many felt now threatened to undermine the very social order of Europe. There was, indeed, the very real threat of new social revolutions should a peace too obviously preserve the pre-war social order. In this context, the Inquiry served an important function: it filled the explanatory vacuum, offering up a vision of scientific self-determination.

The vague nature of self-determination, along with its appeals to social scientific explications of social identity formation, and social scientific methods for territorially circumscribing those identities in nation states, provided the conditions of possibility for the Inquiry. Put simply, if the world was to be built around self-determined nation states-a concept the Inquiry helped thrust into the American psyche-the Inquiry proposed that only its own unique, disciplined understanding of how the social world and sociocultural solidarities formed could explain what constituted nations with scientific certainty.

\footnotetext{
${ }^{126}$ Morey Rothberg, "John Franklin Jameson and the International Historical Community," The History Teacher 26 (1993): 453.
} 
This brings us to the difficult empirical task of explaining the Inquiry and its affect on the concept of nationalism-as-self-determination, and what impact their work had on policy formation. The records of the Inquiry show that by the summer of 1918 the group was a key player in American peace preparations, supplying government departments and Wilson, via House, with reports, maps and pamphlets on regions across the world. By June of that summer, six months after the Inquiry helped shape Wilson's influential Fourteen Points Speech, the Military Intelligence Branch (MIB) of the Ward Council requested from the group a map of the nationalities of Europe, which Lippmann grandly envisioned as a map "from Belgium to Petrograd and from the Baltic Sea to Constantinople." ${ }^{127}$ As House told the New York Post in April of 1918, the purpose of the group was to have "all the data mobilized, so that facts and figures could be pulled out from the total and brought to bear on any phase of that particular region or question in order to give an exact picture of it ... this difficulty was met by making the basis of calculation the least unit of government," and approaching this problem with "the spirit of modern research and scholarly efficiency."

Geographer Jeremy Crampton notes that "the Inquiry sought to accumulate and make intelligible data down to the smallest available geographic unit in what could today be called a spatial database." 128 As Crampton shows, maps were imperative to this database. Using the resources

\footnotetext{
${ }^{127}$ Lippmann to House, 20 June 1918 (entry 1, box 7), Inquiry Paper NARA.

${ }^{128}$ Jeremy Crampton, "The Cartographic Calculation of Space: Race Mapping and the Balkans at the Paris Peace Conference of 1919," 737.
} 
of the American Geographical Society provided by Isaiah Bowman, the Inquiry not only visualized territorial boundaries, "but also distributions of peoples, number and local densities of populations, religious, economic activities, distribution of material resources, trade routes, both historic and potential strategic points, etc."129 This information was at the core of cartographic calculations broadly conceived of as race, but not a hereditary or fixed notion of race.

Rather, as a meeting between key members of the Inquiry in August of 1918 reveals, now faced with the task of drawing up a comprehensive map of the world that reflected known and possible boundaries, the men of the Inquiry understood that because of the highly contested nature of racial boundaries in areas such as the Balkans, maps representing racial distribution would have to reflect its socio-cultural aspects, or what Bowman called its "ethnological meaning," rather than hereditary ones. ${ }^{130}$ On the one hand, this meant taking into account historical conditions that created a social identity among a people over time, including variables such as shared language, religion, and race. But, charged as they were with the daunting task to "set up or provide for the setting up of governments," the Inquiry understood that these would have to be balanced against questions of economic and political "self-sufficiency," as well strategic considerations. A.A. Young argued, for

\footnotetext{
${ }^{129}$ Bowman, "Confidential Information Released for Papers," 31 December 1918 (box 13), Bowman Papers.

130 "Record of the General Conference," 2 August 1918, Shotwell Papers; Also see Bowman Papers (box 13.12).
} 
example, that "there must be some kind of unity, too, in the considerations of economic problems, no less than in topographical problems. There are [sic] the greatest variety of conceptions as to what constitutes a 'well balanced economic unity."' 131 For the Inquiry, the question of how to assess and delimit colonial regions that were economically and politically dependent, as well as strategically important to European powers, was never far from mind. This invited controversy. Robert $H$. Lord flippantly noted that "strategic considerations are usually advanced by persons who are stealing something that does not belong to them," and posed the difficult question, "Are they to take precedence over ethnic rights and popular desire?" Bowman answered, and the room agreed, that "the strategic idea has to be paid attention to, even if ethnic or other boundary [sic] is followed. Slight changes in a line may result in great changes in relative strength." Despite their greatest efforts at reproducible, scientific precision, their discussions of racial, economic, political and strategic boundaries reveals a certain fluidity between what was assumed to be historical fact and more contemporary concerns over power. As George Beer said, "historical research should, I think, decide the necessity and the experts in international law the means of following out the policies deemed necessary." 132

The tension generated by taking account of contemporaneous strategic concerns, alongside historical and ethnological data that often contradicted

\footnotetext{
${ }^{131}$ Ibid

${ }^{132}$ lbid., 8-9.
} 
these strategic and political concerns, created a great deal of tension within the group and made the reports on contested regions all the more contentious and inconsistent in their presentation. For example, while the Inquiry emphasized the "raciological" make-up of the population in the disputed Fiume territory between Italy and Yugoslavia, in the Dalmatian region they chose to emphasize "cultural" similitude between its people and Italy. And, while Poland was built from the remnants of three empires around a shared ethno-linguistic identity and culture, the kingdom of Czechoslovakia was maintained as a multi-ethnic state. As Wesley J. Reisser has noted of the understudied Black Book created by the Inquiry for Wilson at the Peace Talks, while the social scientists were concerned with establishing well defined nations, "no definition emerged to determine what was well-defined, leading to endless possibilities on what frontiers should be proposed."133

This ambiguity is apparent in the archives of the Inquiry and the Commission to Negotiate Peace. Incipient nations understood that the language of social science was the mode du jour for pleading the case for sovereignty. On the one hand, this meant gathering and presenting facts on important measurables such as mineral deposits, the geographical distribution of populations, language, religion and economies. But, on the other hand, aspirant nations also understood that in some cases historical grievances over the systemic removal of one group and colonization by

\footnotetext{
${ }^{133}$ Wesley J. Reisser, The Black Book: Woodrow Wilson's Secret Plan for Peace (Plymouth U.K.: Lexington Books, 2012).
} 
another (as in Alsace-Lorraine and in some of the borderlands between Poland and Germany), as well as strategic concerns about marginalizing the power of the dismantled Central empires, would likely receive an ear. The result was that reports submitted to the Inquiry were substantively inconsistent. Yet all used the language of geographic, historical, economic and ethnographic data, and there was a consistent emphasis on statistical and anthropological methods for organizing peoples into groups. ${ }^{134}$

As social scientific experts acting as the arbiters of nationhood, the Inquiry, loosely with its fellow social scientists in other countries, set the parameters of acceptable claims to nationhood, as well as the language and methods in which such claims to self-determination could be couched. In providing a way of knowing the nation through social scientific discourses, and creating a larger community of thought that assented to these disciplinary mechanisms for imagining the nation, it also made Wilsonianism and the American state appear more cosmopolitan.

They used this scientific cosmopolitanism to differentiate themselves, attach themselves to Wilson's search for a different system of international peace, and then insert themselves in the processes at the Paris talks in 1919. Those Inquiry members who accompanied the diplomats, lawyers, journalists

\footnotetext{
${ }^{134}$ When looked at as a whole, the volume of reports and the methods and presentation used to frame the data by both the Inquiry and aspiring nations is remarkable in its convergence and divergence. There is a substantial amount of work to be done on this beyond the institutional histories of the Inquiry done by Gelfand and Smith. Fore more see the USNA, Records of the Inquiry, 1914-1919, RG 256.2; USNA, Records of the American Commission to Negotiate Peace, 1918-1931, RG 256.3; But see, especially, "Series III: Reports and Studies," and "Series V: Misc. Printed Material, 1913-1927, The Inquiry Papers (MS 8), Manuscripts and Archives, Yale University Library.
} 
and world leaders to Paris received unprecedented access to national resources and diplomatic channels, and were often used over and above the diplomats that served as legalistic-civic international experts. "There is practically no one higher up now except the commissioners," Seymour boasted. "This sounds cocky, but it is the truth ... when we started, the assistant secretaries of the Commission and the Military Intelligence assumed that they were going to give all the advice on policy, taking facts from us when and as they wanted them. The conferences we had with the President on the boat [to Paris] changed this attitude a little. ${ }^{136}$ Shotwell, Seymour, and Bowman all fondly recalled their unparalleled accession to influence, they believed, over the plenipotentiaries. In their post war retrospectives, they relished how their recommendations often bypassed the bureaucracy of even the State Department, arriving directly on the desk of President Wilson through House. ${ }^{137}$

How they managed to do this is a matter of some speculation. But if this event is treated as part of a continual co-development of social science and internationalism than the growing prestige of the social scientists in the generation before the war, their ability to build authority as purveyors of

\footnotetext{
${ }^{135}$ Margaret O. MacMillan, "Lessons of History: the Paris Peace Conference of 1919," O.D. Skelton Memorial lecture Series, http://www.international.gc.ca/department/skelton_clf1/macmillan-en.asp (Accessed 12 May, 2010).

136 "Charles Seymour: Letters from the Paris Peace Conference,"16 December 1918 (series 2, box 44, folder 136), in Charles Seymour Papers. Manuscripts and Archives, Yale University Library. (Hereafter referred to as Seymour Papers); For more on Bowman's direct influence on the peace makers and their geographical mentalities see, Charles Seymour, "Geography, Justice, and Politics at the Paris Conference of 1919, Bowman Memorial Lectures, (New York, The American Geographical Society, 1951), 9-10.

${ }^{137}$ Josephson, Shotwell and the Rise of Internationalism, 52.
} 
useful knowledge to address the social and industrial problems facing the American state, can be seen as integral to their displacement of the traditional functionaries of American foreign policy. This was both more and less than an institutional process. Less because there was no permanent home for the social scientists in state centred American foreign policy-indeed there could not be, by definition, given their interest in staying at arms' length from the state. But it was more because it forever changed the intellectual bases for understanding international relations, however much the instruments of policymaking remained officially housed in the State Department or the White House. American social scientists during the war undercut legalistic and diplomatist precepts, those which had been the bedrock of civic internationalism since the late Reconstruction Era, as guiding principles for internationalism at Paris. The social internationalism that replaced it reflected the disciplinary boundaries of the increasingly well-defined disciplines that made up social scientific research. Even the system of commissions, when one looks at the rosters of the American Peace Envoy, were divided into sections that reflected emergent disciplines-history, geography, politics, anthropology, and to a less refined extent sociology and economics-making it difficult for jurists and diplomats who had been pulled from the inside the state machinery to participate in knowledge production and representation before it was fed to the plenipotentiaries. ${ }^{138}$

\footnotetext{
138 "Map of the Secretary of the Commission" (series 3, box 187), House Papers. Also see Jeremy Crampton for more on the consequences of structuring the secretariat this way, "The Cartographic
} 
The new social scientific experts certainly did not handle all issues at Paris. The Inquiry was not, by any account, "the dominant organ in the proceedings of American Commission." And as Gelfand has rightly observed, "the small staff was at all times outnumbered by personnel drawn from the State Department and other civil departments at Washington, not to mention military staff who served as technical advisers." ${ }^{139}$ This agitated many of the Inquiry experts, of course, who had had greater hopes for their presence at the talks. Many also voiced frustration over being, at times, forced to work in silos, and left in the dark about what was happening in negotiations. But most in the Inquiry felt that what the organization lacked in numbers at Paris was more than made up for in access and influence. Moreover, they believed that what they brought to the talks was infinitely more important, for Wilson's social internationalism, than what was offered by diplomats and lawyers. That is, the issues that concerned them, such as the problem of emergent nations, self-determination, social solidarity, the standardization of international labour norms, were the most burning and significant issues under discussion.

Bowman, among the most vociferous positivists in the Inquiry, claimed to have realized, early on, the newness and the far-reaching consequences of their particular social scientific rationality in determining sovereignty and international order. With the war,

[a] profound change ... took place in the spiritual and mental attitudes of the people that compose this new world. There 
came into being a critical spirit of inquiry into causes, of challenge to a world inherited from the past, of profound distrust of many existing institutions. The effects of the war were so far-reaching that it was indeed a new world in which men found themselves." 140

Part of the basis for the optimism these men felt on their way to Europe was a function of their experience in Progressive politics back home. Having grown up intellectually and professionally in Roosevelt's heady era, watching business and labour leaders work to reconcile their seemingly irreconcilable interests, Bowman, Shotwell and their allies had come to believe that the deeply rooted sources of all conflict-economic and social inequities-could be resolved through the application of disinterested human intelligence. The problem, he argued, was that $19^{\text {th }}$-century peace movements lacked "practical politics," and this had expressed itself in the limp Hague Conferences of 1899 and 1907, which had done nothing "to lessen the scope of the horrors of war." The "whole problem of war," Shotwell wrote, dernanded

a thoroughly objective, scientific study of the war, not from the military standpoint of strategy, but as a vast disturbing phenomenon. This idea of dealing with the impact of war on economic and social life seemed to be a more realistic approach to the problem of international peace. ${ }^{141}$

In this sense, what Shotwell meant by "realistic" was the abandonment of legalism per se and the search for a new approach to internationalism grounded in the actual social experiences of citizens. What the new social

\footnotetext{
${ }^{140}$ Isaiah Bowman, The New World: Problems in Political Geography (New York: World Book, 1928 ), 1.

${ }^{141}$ James T. Shotwell, Long Way to Freedom (Indianapolis: Bobbs Merrill, 1960), 426.
} 
sciences offered, if anything at all, was an ability to drive to the root of human behaviour, in individual and social forms, while avoiding the mechanistic determinism that came from seeing humans either, on the one hand, as solely biological beings, or on the other, through the lens of the airy idealism of $19^{\text {th }}$ century progress that left everything to fate or destiny. The social sciences purported to understand human action precisely as a means of giving such action a sense of rational purpose. That is, the future was made by selfconscious decisions, and better decisions could only be made if the true underpinnings of human action were understood. No diplomat or lawyer could do that.

Throughout his memoirs and later writing, Shotwell reflected on John Bates Clark's work on the newly established Carnegie Foundation for International Peace. This work, Shotwell argued, was a pivotal moment in the conduct of international relations and its move towards a more rational, truly scientific foundation. Clark, Shotwell claimed, was "The voice of pure reason," and "never spoke with greater authority in the social and political sciences." ${ }^{142}$ As such, Shotwell proposed that Clark's work created a more rational foundation on which to govern society and the state, by negotiating the gap between labour and capital, methodologically blending economics and history to pave the way for a form of liberalism that, in the most progressive of styles, was "an instrument of liberation" not "an apology for things as they were." Holding up Clark as his model of international academic

\footnotetext{
${ }^{142}$ James T. Shotwell, “John Bates Clark, 1847-1938," Political Science Quarterly 53 (1938), 243, 239-24.
} 
cooperation, Shotwell proposed that his refocusing of the Carnegie Endowment away from the legalism of The Hague and toward the great socioeconomic question of global interdependence, called into question the "validity of international war, not by the pacifist refusal to fight, but by the consequences of the very acceptance of the principle that is an instrument of policy." 143

For those who prided themselves on being part of this new corps of internationalist intellectuals, the legalistic vision (including a central role for The Hague as a body for enforcement while respecting sovereignty) seemed a musty product supported by an old way of thinking about diplomacy that Wilson and his new social scientists could potentially collapse as the central pillar of liberal internationalism. Shotwell, like Wilson and Bowman, viewed legalism through the same lens he used to look at orthodox economics: as a species of a dated, if not reactionary, understanding of human action. On their own, these were parochial forms of knowledge, mere methodologies based on antiquated notions of natural law. But they demanded a rigorous, scientific mind to synthesize and discover the more basic social laws that applied across cultural and geographical boundaries. These social internationalists were not

\footnotetext{
${ }^{143}$ Ibid., 427. In 1911, Clark had recast the research program of the fledgling Carnegie Endowment for International peace (which was established in 1910 making it among the first non-state international organ for peace in the US) pulling together the largest assemblage of economic data ever and an international community of economic experts from eleven countries who met that year in Europe. Focusing on the interstices of economics and history, the meeting of these experts set out on a project so large that it was interrupted by the war in 1914, and taken back up by Shotwell in the interwar period to be released as a massive one 150 volume work titled an Economic and Social History of the War. For a broader history of Darwinist arguments for and against war as a means for progress see David Paul Crook, Darwinism, War, and History: The Debate Over the Biology of War from the "Origin of Species" to the First World War (New York: Cambridge University Press, 1994), 11, 30, 123-144.
} 
defenders of radicalism, be it Bolshevism or pacifism. Nor were they defenders of the conservative nationalism and isolationist exceptionalism that had defined much of civic internationalism and which would again become the status quo in the US after the war. Instead, by the end of the war it was clear that the Inquiry experts who attended Paris saw their style of social internationalism-validated as it was by finding a champion in Wilsonianismas a more realistic, moderate middle way between extremes in the modern industrial world. Their experience in American life before the war and later in Paris had proven it.

As was the case with those from other nations, America's "experts" at the peace talks have generally been treated as a cohesive group. ${ }^{144}$ This comprehensive moniker has included businessmen, lawyers, academics, professional diplomats, bureaucrats and politicians, who are sometimes presented as combining their expertise, and triangulating their varied perspectives, to arrive at a robust vision of a problem, and a multidimensional plan for achieving a shared goal. But the range of suggestions proposed for how to "do" internationalism, and the varied reactions to and interpretations of self-determination within this new internationalism, reveals a less than harmonious relationship between these "experts." There was, indeed, an important battle among them to control the mantle of "expert"

\footnotetext{
144 See especially MacMillian's cursory assessment of the experts in, Paris 1919, 3-16. Gelfand is less guilty of a superficial exploration of different constituencies, but even his account seems more interested in measuring the value of the expertise by contemporary-functional standards, and with their institutional structure within that framework, than with asking what forms of knowledge were at play or with elaborating on key variances as a way to point at a the larger development of internationalism in the US.
} 
itself.

As previously explored, by the turn of the 20th century, social internationalism was emerging in liberal and progressive circles as a divergent alternative to the legalistic and more restrictive vision of civic internationalists. Both civic and social internationalists had been concerned with the restructuring of an international before the war and imagined a variety of institutions, systems and practices that could facilitate internationalism and arrive at an assured collective security. But the institutional and methodological means that each group imagined cementing this collective security and international community varied in important ways.

Canadian journalist John W. Dafoe put his finger on this distinction several years after the talks. He noted that the "divergences between the Fourteen Points and the text of the treaty as fashioned by the various subcommissions were largely the result of recommendations to President Wilson by his own experts." 145 Importantly, Dafoe was not interested in businessmen, diplomats, or jurists in the American delegation, pointing specifically instead to Haskins and Shotwell. Dafoe recognized that the social scientists Wilson brought to the talks provided, knowingly or unknowingly, a sort of firewall between the American President and the decisions made at the negotiating table. On the one hand, they furnished data for decisions about who would become a nation, where boundaries would be settled, and what criteria would be used to define a nation. They also created a sense of abstract determinism

${ }^{145}$ Dafoe, “Canada and the Peace Conference of 1919," 241-242. 
and objectivism to otherwise political inquiries, that few could combat without being accused of being political on matters Americans were trying to settle objectively. Wilson and his social scientists seemed more easily able to justify things like the exclusion of Germany from the talks, Dafoe argued, and this in turn led to the cursory dismissal of many concerns from fledgling dominion nation-states like Canada, to say nothing of a continued general ignorance and hubris among the Americans on colonial matters.

Treating all issues as "the logical and inevitable consequences of an existing situation and of the historical forces which had produced it," thus created a false certainty among armchair investigators. They wanted to explain international relations using social variables such as ethnicity, language, economics, geography, and culture, that they defined and then held up as universal, determining forces. ${ }^{146}$ Dafoe's sense of the rising emphasis on socio-historical forces, and use of social scientists trained to see these conditions, suggests a broad perception that the reigning logic of international relations-the ontology of internationalism-was changing at Versailles. As Haskins' sense that historical accounts of "nationality" had more weight than strategic considerations implies, this new knowledge used to envision the international was a reflection of America's own sense of the nation-state and who was best qualified to govern.

This difference over the sources of legitimate knowledge about governance helps explain why so many diplomats, lawyers, politicians and

\footnotetext{
${ }^{146}$ Ibid., 243.
} 
even, though to a lesser extent, economists left the Paris talks feeling passed over for what many, both in the U.S. and around the world, derided as the amateur statesmanship of academics. ${ }^{147}$ Opposition from anti-League conservatives on the right and radical pacifists on the left has been the focus of most historical attention given to attacks on Wilsonianism. But there was also a remarkable amount of backroom grumbling and disenfranchisement among pro-League conservatives and liberals inside the Wilson government who felt pushed aside by the new social scientific experts. ${ }^{148}$ While Lansing publicly re-stated support for the Treaty of Versailles and Wilson's approach, he privately bemoaned the State Department's marginalization arguing that the president had failed to listen to his real experts, thereby creating a lack of clarity about how to best define contested European boundaries. ${ }^{149}$ What Lansing refused to acknowledge, however, was that Wilson was listening to experts-just not the ones he viewed as part of an established and often partisan-identified political establishment.

Scholars have pointed out that Wilson's relationship to law, both as a profession and as a binding institution within liberalism's social contract tradition, was a deeply ambivalent one. Though he practiced as a lawyer for a

\footnotetext{
${ }^{147}$ There objections are startlingly reminiscent of the reservations of European great powers like Germany at The Hague Conference in 1899. See Chapter Three for this episode according to A.D. White.

148 "Predict Debate on Bullitt Testimony: Anti-League Senators Want to Use it to Show Clash in Cabinet," New York Times, September 14, 1919.

149 "Peace Envoys Scoff at Bullitt's Story; American Delegates In Paris Ridicule Suggestion That Lansing Should Resign." New York Times, September 17, 1919; Lansing, The Peace Negotiations, 202. See John A. Thompson, Reformers and War: American Progressive Publicists and the First World War (Cambridge University Press, 2003), 43-82 and 261-268 for more on the inner-political wrangling of the Wilson administration and their balancing of Progressive opinion with more conservative nationalists.
} 
year and often exhorted the benefits of international law, Wilson's experience, according to historian John Thompson "had not given him a high view of the qualities required." He complained early in his professional life that "a man must become a mere lawyer to succeed at the bar...and must, moreover acquire a most ignoble shrewdness at overcoming the unprofessional tricks and underhand competition of sneaking pettifoggers." 150 From the period of American neutrality to the Peace Conference, this apparent prejudice against lawyers and the profession was consistent. "Wilson displayed," Thompson claims, "little patience with the niceties of international law regarding war at sea that so concerned Lansing...(himself a professional lawyer)." And by "Paris in 1919, Lansing was by his own account 'deeply incensed' when Wilson flatly declared, 'I don't want lawyers drafting this treaty."'151

One cannot, perhaps, pin too much on Wilson's professional aversions, but clearly the absence of a recognizable continuity between the legalistic tradition of what I have called civic internationalism (which anchored the successes of The Hague Convention in 1899) and the international framework suggested by Wilson, has historians struggling to make sense of where Wilson first got the idea for Article X of the League of Nation's Covenant and how he imagined it being balanced in a larger, more globally inclusive framework. Article X embodied what we would now call collective security,

\footnotetext{
${ }^{150}$ Wilson to Robert Bridges, 29 April 1883. PWW, 2: 343.

${ }^{151}$ John A. Thompson, "Woodrow Wilson and a World Governed by Evolving Law," The Journal of Policy History 20 (2008): 114.
} 
calling for "members to respect and preserve as against external aggression the territorial integrity and existing independence of all States members of the League."152 Early in the drafting process, House gave Lansing a draft of the Treaty. Lansing, echoing others close to the President, found the document "to be crude and to lack knowledge of The Hague Conventions."153 Warren Kuehl and historical realists have carried forward the old BullittKeynes criticism that the Covenant's clauses failed to offer substantial provisions that would actually prevent conflict or breaches between members by understanding the importance of legalistic mechanisms that were enforced by nations with the real power to police infractions. Article XI failed to offer "any automatic obligation to act against breaches of the peace," and Articles XII through to XV proposed that member states would agree to arbitration or, conditionally, submit to an international court. While this seemed like a legalistic recourse within the eventual Treaty and Covenant for the League, Kuehl argues that "the Covenant's clauses on these points, however, did not reflect the thinking of most contemporary internationalists" who had "relegated arbitration, for instance, to an insignificant place by 1919." Instead, he continues, where "conservative internationalists [e.g. the League to Enforce Peace] did include arbitration in their plans they suggested the use

\footnotetext{
${ }^{152}$ David Hunter Miller, The Drafting of the Covenant. 2 vols, (New York: Putnam's Sons Co., 1923), 226, 137.

${ }^{153}$ Cited in George Curry, "Woodrow Wilson, Jan Smuts, and the Versailles Settlement," American Historical Review 66 (1961): 978.
} 
of Hague Machinery." 154 But even this was little more than a symbolic nod to the civic-legal internationalists because, as Kuehl argues, the clauses in the Covenant "offer no evidence that the draftsmen at Paris fully comprehended the aims of the legalists," and a clause on just who could refer a dispute to the international court and what constituted a "justiciable question" was actually removed from the treaty in the drafting stage, with little opposition from the Americans or British. ${ }^{155}$

It is clear that while legalistic mechanisms for internationalism were used and discussed at Paris, the multitude of American civic-legalistic groups who hoped to influence the architects of American internationalism were treated by Wilson as tacit support for an organization tout court, and were not consulted on the mechanisms or framework such an organization should take on. Much has been made of how the decision to marginalize legalist concerns with enforcement and guardianship of sovereignty was a foolish oversight by Wilson, forsaking a well-established internationalist movement. ${ }^{156}$

\footnotetext{
${ }^{154}$ Warren F. Kuehl, Seeking World Order: The United States and International Organization to 1920 (Nashville: Vanderbilt University Press, 1969). 277-278.

is5 Kuehl, Seeking World Order, 270-79.; Lowell to Root, 18 August 1916, Lowell Papers, Harvard MSS; Miller, Drafting, II, 700.

${ }^{156}$ Stephen Wertheim, "The League That Wasn't: American Designs for a Legalist-Sanctionist League of Nations and the Intellectual Origins of International Organization, 1914-1920," Diplomatic History 5 (2011): 797-836. Wertheim makes the timely and important observation, though within a limited historical scope, that the League to Enforce Peace and other legalistic organs constituted a "legalist-sanctionism" tradition in the 1914-1920. Not entirely antagonistic to Wilsonianism, these two major frameworks were the core of pro-league American internationalism, and he explains them as strained by different philosophical-intellectual noting that "Legalist-sanctionists, in sum, prioritized the accretion of law, as decided by courts and backed by force; Wilson, the accretion of habit, as divined and proclaimed by politicians." This author doubts the emphasis placed on Wilson's faith in the politician per se. Rather, additional attention must be given to Wilson's belief that certain kinds of knowledge, harnessed by the politician, were capable of a more cosmopolitan view of the world that was simultaneously in the nationstate but of the world. Nonetheless, Wertheim's distinction holds within the grander framework laid out here, and tracing the development of civic versus social internationalism in liberal internationalism. Also
} 
Wilsonianism rejected these things, not because it was an idealistic internationalism, nor did it reject, fundamentally, the approach of Roosevelt and the legalists. The real impetus, I propose, was an epistemological difference and a shift in mentalities over the proper foundations of knowledge about governance, which manifested themselves in debates over what institutions or disciplines could best represent the international and nations in that international world.

By 1919 and 1920, many of these same experts argued that a reversion to conservative, parochial, nationalist thinking in America had scuttled Wilsonianism. Seymour argued that the defeat of the Treaty and, by extension, the League of Nations, by the US Senate represented a resurgence of the old diplomacy and a rejection of an open diplomacy that could prevent wars. Plucking at Americans' sense of exceptionalism, Seymour argued that the US could not "claim as a nation to have been more far-seeing and altruistic. The Senate debates were tinged with pure national self-interest. It was all thought of in terms of nineteenth century security and prosperity." 157 Wilson had not betrayed his principles, Seymour contended: the people of Europe and America had betrayed him by reverting to narrow-minded national sovereignty rather than reaching for an internationalism built on reasoned social scientific principles that knew no state boundaries. Even before the war, Beer warned that Americans did not understand the imminence and 
desirability of such an international consciousness:

This concept of state sovereignty is a predominant characteristic of modern nationalism. It is to a great extent a philosophical and legal fiction inherited from a different past and out of accord with modern facts. It divides the world into sharply segregated-and from the social and economic standpoint, largely artificial-politico-legal units...All states are in varying degrees infected with this self-regarding nationalism which is the fundamental cause of the present war and which will cause further catastrophes in the future unless the state can be effectively controlled by some form of worldorganization. Apparently such a consummation cannot be fully realized for a considerable time, because the sense of international obligation and responsibility...is more or less undeveloped in all states. ${ }^{158}$

Shotwell, Seymour, Bowman, and Beer, like most of the other Inquiry players who travelled to Paris, had a clear message that carried through their time there and over into their post-war commentaries. Social scientists offered a via media between the extremes of atavistic conservative nationalism and radical bolshevism or pacifism. Social science, they believed, provided the rationalization for an international consciousness that would assure peace because it was based on an understanding of the social conditions that caused the war, the true interdependence of modern society, and the evolution of society away from primitive expressions of martial spirit. All these were needed to shape the peace.

In their correspondence, diaries and official communications, social science was harkened as that which could provide politicians and the public with the standards and norms, the very language of culture, history,

\footnotetext{
${ }^{158}$ George Louis Beer, “America's International Responsibility and Foreign Policy," Annals of the American Academy of Political and Social Science 66 (1916): 72.
} 
population and society, that seemed everywhere applicable and therefore able to rise above provincial, national concerns. Diplomatic relations between governments were not enough to ensure peace because even the democratically elected politicians serving the interests of one electorate inevitably worked against those of another population. Nor were the efforts by labour or business any better; American experts pointed to these groups as inevitably interested in their own selfish causes. Reaching across oceans through scientific organizations and influencing governments through empirical and un-ideological data, the hope of many of the Inquiry experts at Paris was of an international where liberal intellectuals-never advocates for one sphere of life, be it business, labour, politics, law-offered the intellectual rigor and authority that could see beyond states while still weighing their interests.

Seen through the lens of the longer historical development of social science and internationalism, the Wilsonian moment must be seen as just that: a single moment in a larger battle for governmental authority between an internationalism built around fixed legalistic or racialist ways of thinking about the world, and an internationalism built on a view of nations and other social categories of analysis as contingent social structures. In and of itself, Wilsonianism and the Inquiry were not the radical break with past American visions of internationalism one might be tempted to see. Instead, Wilsonianism is merely an exclamation point that punctuates an on-going battle to control the governance of internationalism by controlling the very 
knowledge used to define the international. In this light, the dynamics and compromises the preceding pages have mapped out in looking at the Inquiry point towards consistent attempts to balance these two world views by taking on the ideal of contingent social structures but also maintaining the principle of American exceptionalism. The Inquiry, like the New Historians, the ethical economists and the Washington circle before them, helped develop a form of internationalism, one which is often caricatured as Wilsonianism, into an inclusive, assimilative system that imagined all societies as necessarily developing towards the exceptionally liberal state form; a state form that America already embodied. 


\section{Chapter six}

Secrecy and Scientism: Radicalism and Self Discipline in the Inquiry

Sidney Mezes knew that being cautious came with his job. Recently plucked from an unremarkable career as an administer and teacher of philosophy, the serving president of City College of New York was asked in the summer of 1917 to head a secretive organization that would come to be known simply as "the Inquiry." Given the task by his brother-in-law and President Woodrow Wilson's personal aid, Colonel Edward House, Mezes faced a new set of logistical and administrative hurdles that were familiar to a college administrator in some ways: he was managing people; screening applicants; and judging intellectual merit and rigor. But he was now saddled with the responsibility and stress that came from keeping secrets-and the general confidentiality associated with working on state interests. Mezes knew the potential public and electoral scrutiny that his actions might come under should things be poorly managed or go wrong. It was enough to make any administrator cautious ${ }^{2}$ Mezes was especially so when it came to receiving applications like the letter that landed on his desk on October 5, 1917. The note was well written and the credentials impressive. But it contained some important tell-tale indicators that the applicant could not, by any stretch, be welcomed into the organization that Mezes, Jim Shotwell,

\footnotetext{
${ }^{1}$ House to Wilson, 21 June 1917 (series 1, box 121), House Papers.

${ }^{2}$ For Sidney Mezes's overview of the formation of the Inquiry see, "A Brief Account of the Origin and Development of The Inquiry," (series 3, box 3), Inquiry Papers Yale.
} 
Isaiah Bowman, and Walter Lippmann had been told to staff with only the most

"trusted men."

"May I enquire whether you could make use of me in the work that you

are beginning for the Government," the letter's author asked:

The newspaper accounts are contradictory but if there is any sort of preparatory work to be done looking toward the settlement that must come sometime, and I could be serviceable in it, I should be very glad. I think I have some qualifications...Twenty years of teaching economics and sociology at Wellesley College...a years graduate study in Paris and another in Berlin have left me (though rusty now in speaking them) with a good command of French and German for reading and translation. I spent two and a half years in study preparatory to my book on Slavic immigration. This involved considerable firsthand acquaintance with the conditions and problems-especially the problems of nationality ... My special interest has long been in problems of nationalism and now above all in the different phases of the international problem. My months spent in Stockholm in 1916 with the Neutral Conference were a very valuable experience; so too was the mission on which I was sent by the Conference of Women at the Hague...I should be glad to have a chance to answer questions and would try to be absolutely candid. I do not need to point out that in times like these everyone who does not live in a shell is liable to gross misrepresentations and that no one's views or acts can be judged by hearsay ... I am ready to go anywhere or do anything that will best serve the cause of ultimate peace and good will ... --E.G.B. ${ }^{3}$

Mezes was unfamiliar with the initials or credentials and promptly forwarded the application to his colleague, Walter Lippmann. The reply he got was short: "My dear Doctor Mezes 'E.G.B.' is Professor Emily Greene Balch.",

\footnotetext{
${ }^{3}$ Emily Green Balch to Colonel House, 5 October 1917 (box 1), Sidney Mezes Papers, Rare Book \& Manuscript Library, Columbia University (emphasis added). (Hereafter referred to as Mezes Papers).

${ }^{4}$ Walter Lippmann to Sidney Mezes, 16 October 1917 (box 1), Mezes Papers.
} 
Emily Balch had met with Colonel House many times before the war. Through her close friend, Jane Addams, she had developed an extensive correspondence with the Presidential advisor. ${ }^{5}$ Before that, at a young age, she had made a name for herself in important progressive, pragmatist, liberal, and socialist circles through vigorous municipal activism and as a rigorous sociologist-areas she mixed to great effect. Balch's work with the settlement house movement, and on works like Public Assistance of the Poor in France (1893) and A Study of Conditions of City Life (1903), brought her into the innercircle of prominent feminists and reformers like Addams, with whom she served as an American delegate at the Congress of Women at The Hague in 1915, and worked on the subsequent establishment the Women's International League for Peace and Freedom. Balch was also known as a formidable scholar, being the first American woman student to receive a scholarship for doctoral study in Germany and France, briefly studying sociology with Albion Small at the University of Chicago (the first sociology department in the US), and by publishing the still canonical sociological study Our Slavic Fellow Citizens (1910), which explored the lives of Slavic peoples in Europe and America in cultural rather than the more in-vogue scientific-racialist terms. Balch was not one to seek out direct confrontation, but was quick to lend her expertise as a social scientist to debates, especially on questions of

\footnotetext{
${ }^{5}$ For Balch's correspondence with House see House Papers (series 1, box 10, folder 283).
} 
nationalism and internationalism. ${ }^{6}$ Yet-or rather, because of these

associations-she was also an extremely controversial figure, especially for a secretive organization that was supposed to be quietly engaged in scientific work.

And so, Balch's letter, like almost every other of the hundreds of letters and applications sent to the Inquiry by school teachers, political followers, military men, and university professors, received the standard reply: "Colonel E.M. House is so busy at present, especially with the preliminaries of his new assignment, that he is unable to answer correspondence" and has "asked me to acknowledge and thank you for your letter...to say that it will be placed on file for future reference."7 But Balch was not one to accept platitudes. She replied, "I trust that this will not be a merely perfunctory pigen [sic] holing, but that by the New Year at latest, some way to make use of me may be found."8 She also took the unusual step of requesting reference letters from close associates already working within the machinery

\footnotetext{
${ }^{6}$ Geoffrey Stone, Perilous Times: Free Speech in Wartime from the Sedition Act of 1798 to The War on Terrorism. (New York: Norton, 2004), 151-152. Before submitting her application to the Inquiry, the thenWellesley professor had testified before a Congressional committee where she challenged the "Disaffection Provision" proposed within the Seditions Act of 1917. Balch argued that "disaffection" was too abstract a notion to base any law on and that a sense of dissatisfaction with authorities was neither a charge that could be proven, nor a necessarily negative effect in any democracy. Disaffection was so vague it would easily stoke "war hysteria," she warned, and no judge or jury could be expected to rise above that hysteria for fear of also being accused of fomenting disaffection. For Balch, the ability of established or power hungry national interests to exploit vague laws and to sweep up society into emotive whirlwinds was sociologically predictable and too obvious a threat to be considered controversial. See also Mary Jo Deegan, "A Very Different Vision of Jane Addams and Emily Greene Balch: A comment on 'Nobel Peace Laureates, Jane Addams and Emily Greene Balch,"” The Journal of Women's History 7 (1995): 6-26, by Harriet Hyman Alonso.

${ }^{7}$ Mezes to Balch, 19 October 1917 (box1), Mezes Papers. The Mezes papers at Columbia University contain the most extensive records of accepted and rejected applications and inquiries about the Inquiry, not the Inquiry documents at the NARA or Yale, nor the Mezes papers at Yale.

${ }^{8}$ Balch to Mezes, 25 October 1917 (box 1), Mezes Papers.
} 
of war-mobilization. Joseph Lee, the Head of Recreation and Leisure with the Commission on Training Camp Activities, whom Balch met through her work on immigration and municipal reform in Boston, endorsed her organizational and intellectual capacities and addressed the stigma of her pacifism directly: "She is a pacifist," Lee wrote, "but she is also one of our best citizens and one I have tried, sometimes unsuccessfully, to have work with me in various civic enterprises. Now she is turning to this constructive piece of work [to] which she is especially adapted both by intelligence and temperament." Henry Abrahams, an old friend, testified to Balch's patriotism and "breeding," assuring Mezes that she came from "an old Puritan Family ... an American who loves the country and its flag."

Balch's doggedness may well be an indication that she anticipated her public pacifism, proclaimed socialism, and scepticism of the political elite's use of emotion for war would trump her proven record as a social scientist, and her unquestionable expertise in fields that would have been extremely useful to the under-specialized Inquiry. Perhaps sensing Balch's conviction, and knowing her public profile, Mezes departed from his usual standard and addressed Balch personally.

Of course you want a frank answer ... let me say, therefore, that there is no immediate prospect of our being able to avail ourselves of your offer, as the work in which you appear to be

\footnotetext{
${ }^{9}$ Joseph Lee to Mezes, 29 October 1917; Henry Abrahams to Colonel House, 9 November 1917 (box 1), Mezes Papers. For additional letters of reference see Paul H. Hanus to Sidney Mezes, 5 November 1917 (box 2), Mezes Papers. For an examination of Hanus see Gary Moore, "Paul Henry Hanus: A Pioneer in Vocational Education from Academia," Journal of Vocational and Technical Education 10 (1993), 37-43.
} 
especially interested has either been assigned or is not to be undertaken for sometime in the future. We shall be glad to bear in mind your availability.

Balch graciously replied that she was "greatly obliged ... for your definite and kind reply and shall hope that in the future it is felt that I can be of service I may then be in a position to give a reply." ${ }^{10}$ Nothing more came of her application to the Inquiry, and this quiet exchange would pass unnoticed in the historical record for nearly a hundred years.

Historians' oversight of an application from a future Nobel Peace Prize Laureate to the Inquiry is a telling gap in our historical voir. This untold story, along with those of other significant and highly regarded social scientists who would be locked out of the organization reveals an important and underexplored connection between internationalism and the social sciences around the Great War, where both were influenced by attempts to control how and who could most legitimately govern the state and direct its international relations. The Inquiry's authority stemmed initially from the new and central place social scientific experts carved into Wilson's efforts to structure an international alternative to balance of power that had caused war. As the last chapter detailed, the rising power of an epistemic community of social scientists who could objectivize states according to principles that reflected particular social characteristic familiar to Americans, converged around Wilson. Using the Inquiry, and buttressing the idea of America as a stateless

\footnotetext{
${ }^{10}$ Mezes to Balch, 17 November 1917; Balch to Mezes, 18 November 1917 (box 2), Mezes Papers.
} 
society, both in their own organizational structures and in the knowledge they generated-over and above that offered by other nation's experts and civiclegalistic internationalists in their own country-the Inquiry actors manoeuvred themselves to the core of governmental knowledge. What this chapter will show is that the Inquiry's projection of power did not only marginalize those who sought to anchor liberal internationalism to knowledge build around both a civic and statist view of the proper functioning of internationalism. Rather, the power of the Inquiry also benefited from its marginalization of formidable intellectuals who questioned the permanence of the American nation-state, and the characteristics that underpinned America's national identity and, by extension, the ideal that America's exceptionalism was borne out by the construction of knowledge outside of the state and the societal influences that hoped to control it.

Like Balch, we will see that many of the intellectuals marginalized by the Inquiry were of great ability, but of dubious ideological and personal status, at least from the normative perspective the Inquiry shared within the hegemonic framework of America's liberal political culture. The result was that the Inquiry became a more ideologically conservative think-tank, one that smothered discussion of the mutability of ethnicity, the socio-economic conditions governing democracy, and the historical permanence of nation states, if any of these discussions were ever given a chance to develop at all. In this sense, the ontological assumptions of those social scientists who came to dominate the group, remained much more closely aligned with the self- 
legitimizing instincts of the nation-state. It would be hard to imagine it any other way of course. What state would employ intellectuals who sought to undermine the prerogatives of the state? But the problem in Paris was, of course, that such conservatism sanctified an essentialist image of the nation and led the United States to endorse territorial settlements along those lines. Or rather, the more pluralist vision of the nation that some of the progressive intellectual outliers in America imagined for the US was simply outside the mental space of those who did manage to influence US policy in Paris.

This chapter offers a two-part account of how the Inquiry gained and maintained its authority. After briefly addressing where this exploration fits alongside other accounts of the marginalization of radicalism in professional, political and cultural circles, I look at four people, in addition to Balch, who were either rejected or marginalized by the Inquiry on other grounds: Walter Lippmann; Thorstein Veblen; John Dewey; and W.I. Thomas. To set the stage for understanding their paths to and from the Inquiry, I also examine how these cases highlight the mode of internal policing, public and media relations, and organization used by the Inquiry between 1917 and 1918. While very much different in their own right, by exploring the ideological streamlining of these progressives from Inquiry on the pretence of social 
scientism this chapter offers us a look at the nature of liberal internationalism in America as it stood before the entry into the 1920s. ${ }^{11}$

\section{Liberal Social Science and Radicalism around the Great War}

The Inquiry, as I have said, was part of a broader downloading of administrative power and accountability away from government onto civic organizations in the lead up to and during the First World War. Historians dealing with this longer narrative have traced it through to varying consequences. Christopher Lasch, Nancy Cohen and, more recently, Christopher Hedges, have all argued in different ways that liberal intellectuals and America's "pragmatic-liberals" systematically sacrificed radicals heading into the war. According to Lasch-borrowing from Bourne's criticism of Dewey-intellectuals made this regretful compromise in order to save themselves. In key publications like The New Republic, they set radicals and pacifists adrift and took "refuge in the hard-boiled rhetoric of realism."12 Liberals' attempts to protect themselves from the perceived illiberal predations of labour and farm populism, as well as efforts to give themselves a role to play against the acquisitive power of capital, can be traced back to well before the Great War. Cohen argues that in the period of liberal

\footnotetext{
${ }^{11}$ While progressivism is a large and often clumsy catchall, Balch, Lippmann, Thomas, Dewey and Veblen have all been situated as progressives-if of very different stripes. For more on the internationalism of Balch see Patterson, The Search for Negotiated Peace, especially 97-135. For a helpful rubric of the segments of progressivism and for a placement of Lippmann in it, see John A. Thompson, Reformers and War, 29, 84, 33-40.

${ }^{12}$ Lasch, The New Radicalism in America, 184.
} 
reconstruction (1867-1914), from the Gilded Age into the early progressive era, liberal intellectuals came to posit "an active role for the state in society and economy, even as it justified constraints on democracy and the ascendancy of a corporate elite." 13 Cohen proposes that in moving "decisions of regulation from their traditional locus in the legislative and judicial branches...to new expert-staffed administrative agencies," liberals effectively divorced much of America's democratic tradition "from partisan politics, legislative direction and popular politics" and instead instituted an administrative politics that regulated and preserved corporate capitalism. ${ }^{14}$ Thus, rather than courting a democratic order that might overturn, "the liberal class" abetted capital by moving decision-making into a new administrative structure, quietly pulling representative democracy away from the public and into a small managerial class. ${ }^{15}$ Echoing this criticism, Chris Hedges has proposed that, "the [First World] War destroyed values and self perceptions that once characterized American life and replaced them with fear, distrust

\footnotetext{
${ }^{13}$ Cohen, The Reconstruction of Liberalism, 5.

${ }^{14}$ Ibid., 224, 255. For more works that build on the idea that liberalism has gradually shifted American political-culture to the right, see Gabriel Kolko, The Triumph of Conservatism: A Reinterpretation of American History, 1900-1916 (New York: The Free Press, 1963); and James Weinstein, The Corporate Ideal in the Liberal State, 1900-1918 (Boston: Beacon Press, 1968). On "corporate liberalism," see R. Jeffrey Lustig, Corporate Liberalism: The Origins of Modern American Political Theory, 1890-1920 (Berkeley: University of California Press, 1982). For works that treat progressivism as more radical in scope and aims, see Alan Dawley, Changing the World: American Progressives in War and Revolution (Princeton: Princeton University Press, 2003); Robert D. Johnston, The Radical Middle Class: Populist Democracy and the Question of Capitalism in Progressive-Era Portland, Oregon (Princeton: Princeton University Press, 2003); Michael McGerr, A Fierce Discontent: The Rise and Fall of the Progressive Movement in America, $1870-1920$ (New York: Oxford University Press, 2003); Shelton Stromquist, Reinventing "The People": The Progressive Movement, the Class Problem, and the Origins of Modern Liberalism (Champaign, Ill.: University of Illinois Press, 2005).

${ }^{15}$ Kloppenberg, "Review of Nancy Cohen, The Reconstruction of American Liberalism," 62.
} 
and the hedonism of consumer society." The rise of mass-propaganda, the emergence of the very idea of manageable "public opinion," and the realization that reason had emotive foundations that could be manipulated, all emulsified around the cause of a nation at war. The overarching result, Hedges argues, was "liberal institutions" purging the critics of war to protect the establishments and livelihoods wrapped up in them. At the same time, the capacities to control the state, to use its bureaucracies and create political movements for reform and progress, were turned quickly from domestic concerns with poverty, housing and employment and towards a new international activism, where they fell under the increasing influence of the corporate class or capital. ${ }^{16}$

Rather than staying within this rather limiting tragic narrative mode, I want to take stock of the forms resistance around the Inquiry, and the contestations of what constituted rational behaviour. ${ }^{17}$ In doing this, we see how the ideal of "stateless" knowledge, and the movement outward of that knowledge about the state, away from apparatuses recognizable as the state was an effect that exerted its own force. In this way, the idea of a cosmopolitan knowledge led by experts outside the state became its own barrier, its own

\footnotetext{
${ }^{16}$ Chris Hedges, Death of the Liberal Class, (New York: Nation Books, 2010), 65-66; Cohen, Reconstruction of Liberalism, 223.

${ }^{17}$ For a critical overview of, and a similar attempt to move around, such tragic and romantic narrative modes see James Livingston, Pragmatism and the Political Economy of Cultural Revolution, 1850-1940 (Chapel Hill: The University of North Carolina Press, 1997), xvi-xxvii; Also see Livingston's Pragmatism, Feminism, and Democracy: Rethinking the Politics of American History (New York: Rutledge, 2001), 13, 40-43 for a treatment of pragmatism as part of a philosophical attempt to break with the old tragic mode used by historical accounts on the social and political left.
} 
morality. Hemmed in by the realism it hoped to enforce as a new epistemological basis for internationalism, and needing to maintain their scientism, the social scientists of the Inquiry policed the organization and its boundaries by placing limits on what was considered acceptable discourse about the nation-state. Any personal moral transgressions, or political dissidence were understood as intolerable liabilities that would impugn the cosmopolitan disinterestedness of the Inquiry and, by extension, the social sciences generic ability to contribute objectively to political governance.

As we have already seen, the use of the Inquiry as a scientistic, nonstate body under Wilson was indicative of a changing concept of internationalism, moving away from static legalistic and racialist frameworks that had once complimented social science, and towards new social scientific institutions and practices that were better able to appear distant from the state and society. On the one hand, these new institutions and practices were used to create a sense of cosmopolitanism that was meant to distinguish social scientific rationalities from that of diplomats, jurists and other international experts. But, on the other hand, the sense of intellectual distinction that these epistemic communities created also went deep within the fabric of the Inquiry, creating fissures between professional identities within the organization as more devout social scientists played up their realism by branding non-conformists as idealistic. When the Inquiry was still the unnamed amalgam of Lippmann (journalist), Miller (lawyer), Mezes and Shotwell and a smattering of newly recruited academics, the latter were quick 
to point out the difference in methods that separated them from the lawyers and journalists in the group. For example, Seymour, an early addition to the Inquiry, would later say that, "Lippmann furnished the abstract ideas which found their way into a good many of the memoranda of the American Delegation and ultimately into some of President Wilson's public speeches."18 Shotwell concurred: "Seymour's summary of the trend of Mr. Lippmann's contribution is correct,"

if "abstract ideas" is another term for "general principles." They were ideas, moreover, which Mr. Lippmann sought to make concrete by testing them in the laboratory of research. My own tendency was to work the other way on, from the historical background out into the problems of the day. ${ }^{19}$

History was, in Shotwell's mind, a more empirically rooted way of knowing the world because it inductively worked from concrete findings outward to general principles. It did not, as Lippmann was here being accused of doing, build policy bases from theoretically desirable hypotheses. This selfdistinction was critical to the authority and self-identity of the individual social scientists in the Inquiry and, by extension, to the projected image of the organization as free from ideologically motivations or politics biases. Their work could overturn a more imperial approach by examining constituent populations according to their local wishes rather than by fixed political principles that reflected the dominant order of a state and society.

\footnotetext{
${ }^{18}$ Charles Seymour, The Intimate Papers of Colonel House (New York: Houghton Mifflin, 1928), III, 171.

19 James Shotwell, At the Paris Peace Conference, 3. For an overview of Lippmann's efforts around the war see, Heinz Eulau, "Wilsonian Idealist: Walter Lippmann Goes to War," The Antioch Review 14 (1954): $87-108$.
} 
This begins to explain why Lippmann was slowly, but assuredly, pushed out of the Inquiry in early 1918. By January, as the first reports of the organization were being completed, the Inquiry made what is perhaps its most significant mark on the policy direction of American peace plans. With Wilson's calls for a "New Diplomacy" and the growing need to court the European left away from similar rhetoric by Lenin, Wilson asked the Inquiry (through House) for peace aims that could position US interests at the top of a global peace agenda and at the forefront of European popular thought. ${ }^{20}$ The Inquiry's efforts culminated in a draft of what would become the "Fourteen Points" speech. As Neil Smith has noted, "using physical maps, statistics on national, ethnic, and linguistic groups, and information on trade, economics, and political movements, [the members of the Inquiry] began mapping the contentious regions of Europe and matched these to the details of the secret treaties."21 The resulting document, "The War Aims and Peace Terms It Suggests", was sent to House before Christmas in 1917 and contained important territorial data as well and the statements of principle around self-

\footnotetext{
${ }^{20}$ Walter Lippmann, The Political Scene: An Essay on the Victory of 1918 (New York: Holt, 1919), ix-xi. See Mayer, Wilson Vs. Lenin, 369-78, for a more thorough overview of the political and diplomatic backdrop to the ten months between America's entry into the war and Wilson's Fourteen Points. Mayer's work notes that Wilson was certainly not the first to use the term "self-determination." Rather, Wilson was a latecomer to the concept and pressed into co-opting it only when confronted by the broad appeal, and the threat of such appeal, posed by the Bolsheviks.

${ }^{21}$ Smith, American Empire, 123.
} 
government and self-determination that the American experts believed must guide a just and realistic settlement. ${ }^{22}$

The response to the Fourteen Points around the world was immediate and largely positive, vaulting Wilson to a global leadership position. "The inner circle of the Inquiry was elated at the quick sign of their importance, but work only intensified," Smith writes. While they successfully "put words into the mouth of the President," as Lippmann bragged, the difficult work of gathering data about much of the world still lay ahead. ${ }^{23}$ In the days that followed, the initial success of the Fourteen Points was eroded by the friction of personalities and differences in working styles that became more pronounced with the tedious work, magnifying important ideological tensions within the group. The primary division that began to emerge in the Inquiry was between Lippmann, who took credit for inserting the notion of selfdetermination, which guided the principles of Wilson's Address and later speeches (although the precise term self-determination was slow to take hold), and Shotwell, Bowman, and Beer, who saw their empiricism as fundamental to the work of spelling out the territorial claims and substantive principles in the speech. ${ }^{24}$

This division between Lippmann and the social scientists became more distinguished by the spring of 1918 , when Bowman openly complained to

\footnotetext{
${ }^{22}$ E.M. House, House Diary, 4 \& 9 January, 1918, House Papers; Steel, Walter Lippmann and the American Century, 133-34.

${ }^{23}$ Smith, American Empire, 125.

${ }^{24}$ Throntveit, "The Fable of the Fourteen Points," Diplomatic History 35, no. 3 (2011): 459.
} 
Shotwell that Mezes's weak leadership had allowed Lippmann to wield too much influence and to take too much credit for the group's work. By May, after the organization received an expanded budget from the president's discretionary war fund, Bowman's frustration boiled over when he discovered Lippmann planned to use it for more personnel in completely new sections of the Inquiry, neglecting existing groups like Bowman's own division for geographic study. Additionally, Bowman resented that Lippmann blocked attempts to remunerate the American Geographical Society for the thousands of man-hours that his former organizational employer had poured into the secretive group. Bowman attributed both of these decisions to Lippmann's poor organizational capacities.

As the group began to draw more information from government bureaus and other international peace groups, and as demand for maps grew, Bowman wrote to Mezes to demand "a stricter division of functions among the officers of the Inquiry and an exact definition of status and appointments."25 Bowman's dismay about disorganization stemmed from a feeling that he was being intentionally locked out of the Executive, which he had come to believe was being dominated by Lippmann. ${ }^{26}$ "One experiment followed another under the direction of Lippmann," Bowman complained, "until both the map program and the drafting staff became entirely disorganized and demoralized...during the months of May and June the state of disorganization

\footnotetext{
${ }^{25}$ Smith, American Empire, 127-132.

${ }^{26}$ Ibid., 127.
} 
of the Inquiry had become so extreme that about half of the principal men on it had told me they were going to resign." Bowman took a prolonged vacation from the New York AGS headquarters and, while away, worked to undermine his superiors at the Inquiry. First he spoke with Lippmann about Mezes: they agreed, "Mezes was a very stupid director." But when Lippmann asked Bowman to support his request (to House) for a mandate to reform the organization, Bowman backed off, claiming he "would not plot against Mezes." 27 Intentionally or otherwise, Bowman crossed Lippmann, and the schism between the journalist and the social scientists grew.

How much of this was simple bureaucratic territoriality, or a difference of personality, and how much of it stemmed from a deeper discursive hostility toward Lippmann's lack of formal scientific training is difficult to say. But Bowman was openly sceptical of, if not threatened by, Lippmann's "unempirical" style. Nine days after the November armistice, in a letter to Clive Day while both served on commissions at the talks, Bowman "took the occasion to spill his thoughts" on Lippmann:

Your report of Lippmann's impressions of the Inquiry correspond in all respects with my expectations. If public and private opinion in the United State were swayed by the New Republic, I might tremble; but "all men everywhere" are not in agreement with the opinions of this sheet. Lippmann no doubt reports the Inquiry and its personalities in such a way as to give the impression of full ownership. At any rate that would

\footnotetext{
${ }^{27}$ Bowman, "Notes on the Inquiry, " 20 November 1918, Shotwell Papers.
} 
correspond precisely with his attitude in New York. ${ }^{28}$

Despite doubting the magnitude of the New Republic crowd's influence, Bowman and others were certainly worried about what influence they would wield with a social scientific peace organization. For those already brought into the Inquiry because of their like-mindedness, keeping fringe elements out of the group was central to its legitimacy in the eyes of the State and War Departments, the White House, the general public, and the concentric circles of elite intellectuals that overlapped with those aware of the Inquiry.

Even as he experienced what amounted to a coup, led by Bowman, Mezes agreed with Bowman that Lippmann represented a "liberal" element that was a very real problem for the group. Mezes wrote to a still embittered Lansing: "Naturally we have had difficulty from time to time in keeping the theories of our collaborators out of the work, and in some cases it has not been wholly possible to do so."29 While Mezes complained that Bowman was "academic and unpractical," and he was quick to take administrative help from Lippmann in running the Inquiry, both Bowman and Mezes used their correspondence with their political liaisons to emphasize that they alone possessed the disciplined intelligence that did not advocate the views of the "extreme liberals" that Lippmann represented. ${ }^{30}$

\footnotetext{
${ }^{28}$ Ibid.

${ }^{29}$ Mezes to Lansing, 10 June 1918 (box 2), Mezes Papers.

${ }^{30}$ Bowman, "Notes on the Inquiry," Shotwell Papers.
} 
It was not as simple as equating liberalism with empiricism, as Neil Smith has argued of Bowman. Rather, the ideological streamlining that occurred in the Inquiry suggests that this was as much strategy as belief-that there was an understanding that the best way to maintain access and authority in directing state policy was to avoid controversy by creating rigorously empirical, scientistic works that gave what appeared to be concrete criteria for organizing the world. Central to that sense of disinterestedness was being able to provide objective criteria for establishing the boundaries of nationstates. But the ontological makeup of the nation-state was far from agreed upon. For conservative liberals like Bowman and Mezes, any international order, and the maps or other representations of it, would have to reiterate dominant political and cultural discourses about the US in the world, not least that nation's exceptionalist self-identification. Their position was less controversial precisely because it offered "evidence" and "data" that reinforced the connection between internationalism and strong nation-states rather than a strong cosmopolitan liberal class that could check both commercial and state powers on an international scale.

By August 1918, a besieged Lippmann simply gave up on the Inquiry and left for France to serve on a Military Intelligence and Propaganda mission. He realized he was hamstrung in the Inquiry by ineffective leadership on the one hand, and by what he thought were often-duplicitous "social scientists" who seemed to have little regard for him as an intellectual or empirical 
thinker. ${ }^{31}$ With Mezes's leadership still flagging, and with Lippmann out of the picture, Bowman quickly organized himself as the head of a new Research Committee, which he commissioned. The move, with help from Miller and the legal section of the Inquiry, effectively placed most of the social scientists under Bowman's charge and out of the reach of the rest of the Executive. Bowman then began to communicate with House directly, moving intentionally to re-define the mandate of his section and purposefully bypassing Mezes in all decisions. This was a deeply personal power struggle but it points out an important, if somewhat imprecise, distinction that was made within the Inquiry. Lippmann's departure, along with the conflict between Bowman and Mezes, shows that more conservative methodologies, grounded in a faith in social scientific power to realistically reflect rather than shape social forces, were rewarded with continued access to governmental power. The more that one was willing to focus on the "territorial, political and racial questions" that Wilson thought were most important throughout the summer and fall of 1918 , the more power they had within the Inquiry and the more likely they were, eventually, to go to Paris and serve as an adviser there. ${ }^{32}$

\footnotetext{
${ }^{31}$ Trygve Throntveit, "The Fable of the Fourteen Points: Woodrow Wilson and National Self-Determination," Diplomatic History 35, no. 3 (June 1, 2011): 445-481.

32 "Statement Made by Dr. Bowman concerning the reorganization of the Inquiry," Notes taken March 14, 1932, Shotwell Papers Columbia. For more on Bowman's role and account of events, see Smith, American Empire, 122-134.
} 
Accusing Lippmann of being too theoretical or being unable to deliver the sustained and often stifling flow of data deemed necessary by the social scientists in the organization to its goals, in many ways made the Inquiry less a body for analysis and more a simple information aggregator that could muster data that fed dominant discourses in and about the state. But, beyond this, it also gave the more conservative social scientists in the Inquiry a chance to excise a man that most viewed as a liability for his theoretical leanings and his connections to segments of liberal progressives and the left, which his hiring had been meant to placate. As they made their journey aboard the George Washington to France, Seymour wrote to his family that he and his colleagues worried that "Lippmann's connection with the Inquiry had discredited the whole organization." ${ }^{, 33}$

\section{"Scholarly Equipment and Bias"}

We see with the Inquiry that its core members combined a handful of axioms-about economic laws, the historical processes governing national development, the indisputability of American exceptionalism, and the teleological nature of liberal democracy-with the new inductive methods of their respective disciplines. In this way they did two things. First, they cast doubt on the value of theoretical speculation, tying it increasingly to what they thought were tainted ideological forms of political activity, namely

\footnotetext{
${ }^{33}$ Seymour to his family, 12 December $1918, P W W, 53 ; 356-57$.
} 
revolutionary socialism, but also anything that was not affirmed by their sense of what was empirically observable. In this sense, even the philosophically pragmatic assertion that the world is plastic, that reality is constantly constructed by action, was seen as dangerously open-ended. Second, they came to understand that making claims to objectivity reinforced their respectability, as long as they maintained that distance from the emotionalism of politics that afflicted democracy. The objectivity provided by a social scientific method was above politics; and so social scientists who gave the state access to their knowledge, granted that state a powerful claim to legitimacy. It is this respect that the two institutions-the positivist social sciences as practiced by some American academics and the state as envisioned by Woodrow Wilson—came to legitimate each other.

The "realities" of politics, especially the pressures of a growing and palpable distrust of the academy and the liberal class generally, were very real for those caught in those powerful inner-circles, but they were no less ideological for being more powerful. In this respect, the Inquiry provides a case study of how basic ideological assumptions about the background of the experts, their methods, the questions they asked and-perhaps most importantly - their views on internationalism, mattered. In dispersing peace planning into the civil sphere and away from state institutions accountable directly to the elected government, an implicit assumption developed: that they would self-police and avoid generating unwanted political controversy. As such, the same reformism that underpinned Wilsonianism as an international 
outlook (the view that nation-states gradually built up the social and politicalculture needed to earn the right of sovereignty) came to define the selection of individuals for the Inquiry. Access to steering state policy was a luxury for those who possessed particular characteristics, believed certain things, and showed deference to existing political-institutions.

Even before the Inquiry's Executive was formed, the main figures to whom House initially turned were careful to emphasize four categories in their analysis of prospective candidates: professional prestige, open identification or sympathy with Wilson's internationalism, interpersonal and institutional relations, and easily identifiable ideological orientation. Each of these was viewed through the lens of a candidate's political leanings, social networks, and loyalty to the state. In a solicited list sent to Mezes, Stephen Duggan, a professor of politics at CUNY and member of the Carnegie Endowment for International Peace, carefully documented the "qualifications" of scholars like James Shotwell, Carleton Hayes, John Bassett Moore, Archibald Carey Coolidge, George Louis Beer, and William R. Shepherd. Duggan was adamant that all of these men were "authorities", but also that all adhered to "the new view of international relations and of a world order." He was also careful to expose vulnerabilities in candidates' resumes or reputations. For example, he told them that Beer was "exceedingly pro-British" but, as a widely published supporter of Wilson, he "could be of immense service were he associated 
with the commission." 34 William R. Shepherd was "a profound student also in the field of colonial history and colonial problems," who Duggan defended as someone who would not "allow anything to intervene with a scholarly service to the United States." But he had been "known as a pro-German when the Great War broke out,"35 and as such was never brought into the organization. Thus while, Beer's openly pro-Allied views would take him to the Inquiry and onward as an advisor at Paris, Shepherd was kept well away.

Appealing to a candidate's "detached views," "open-mindedness to the facts," or "accurate scholarship," held some weight, but when weighed against the accusations of pro-Germanism or pacifism, it rarely balanced the scales. And this not only applied to the social scientific sections of the Inquiry. For example, when looking to fill their legal section, colleagues vouched for Alpheus Snow as an expert in international law and political science. He was widely held as the primary candidate for the position by insiders like Miller. However, when Mezes asked a zealous patriot group, The American Protective League, for information on Snow and other candidates, he received a warning from them via the Attorney General, Thomas Gregory:

The impression I gather is that on the basis of a good deal of attention to the work of The Hague Tribunal and a series of peace efforts that have grown out of that institution since 1899 , he is more or less affiliated with men who could be termed,

\footnotetext{
${ }^{34}$ Stephen Duggan to Mezes, unknown date 1917 (box 1), Mezes Papers. As early as 1916 Beer publicly advocated a variant of internationalism similar to the Wilsonianism that emerged in 1918-1919. See George Louis Beer, “America's International Responsibilities and Foreign Policy," Annals of the American Academy of Political and Social Science, 66 (1916): 71-91.

${ }^{35}$ Duggan to Mezes, Mezes Papers.
} 
"pacifists." I am informed that several weeks ago he expressed dissatisfaction with the policy of President Wilson. ${ }^{36}$

Snow was immediately dropped from consideration and the committee moved on. ${ }^{37}$

Yet, at the same time, the simple mention of pacifism was not enough to scare off Mezes or the more fiercely scientistic Bowman and Shotwell from some rank-and-file candidates. In fact, the selective branding of some experts as pacifists appears to have served as a conveniently ambiguous shorthand that a candidate was a political and public liability who could open the Inquiry up to accusations of playing politics or being too liberal. Such liability may have stemmed from refusing to toe the ideological line on assumptions that were thought key to navigating American political culture or adhering to the exceptionalism within Wilsonianism. The Inquiry reached far and wide for assessments in the search for information so that the Executive "may know something of their scholarly equipment and of their bias."38

They did not always have to actively seek information about applicants. Once word of the Inquiry was leaked, unsolicited mail began to arrive from political insiders, university colleagues and the general public warning of pro-Germans and pacifists reported to be close to the commission. Frank Polk, a Councillor of the State Department, wrote to House in 1917 to warn that Edward B. Krehbiel, already a full member of the Inquiry and professor at

\footnotetext{
${ }^{36}$ Attorney General Gregory to Mezes, 8 November 1917 (box 1), Mezes Papers.

${ }^{37}$ Gelfand, The Inquiry, 72-73.

${ }^{38}$ Frank Polk to Sidney Mezes, 14 December 1918 (box 1) Mezes Papers.
} 
Stanford University, was actually "a dangerous German sympathizer." Krehbiel circulated in the networks of "extreme liberal" academics that were widely understood as persona non grata and barely tolerated by the government or the social scientists on the Inquiry. Krehbiel wrote for publications like The Dial, and was closely associated with international pacifists like British peace activist Norman Angell, and former Stanford president David Starr Jordan. ${ }^{39}$ This was enough scrutiny for Mezes, who fired Krehbiel.

American liberals and left progressives shared the hope of creating a new world order, making the world safe for democracy, and demonstrating that a "new diplomacy" could supplant the amoral European balance of power. These reformist aims were precisely what allowed Wilson to build an ideologically broad coalition for America's entry into the war in the first place. But for the more nationalistically inclined liberals in the Inquiry, the potential for scientific management needed to be tempered by, or at least anchored to, well-established customs in law and society. Walter Hines Page, then ambassador to Britain, and an early advocate of a committee like the Inquiry that would mirror British preparations for peace, bemoaned that British liberals and internationalists were looking to the wrong people for internationalism in the US. The British, he argued, invite over here-and they permit to come-cranks on prohibition, experts in the investigation of crime, short haired

\footnotetext{
${ }^{39}$ David Starr Jordan to Mezes, 2 February 1918 (box 1), Mezes Papers.
} 
women who wish to see how British babies are reared, peace cranks and freaks of other kinds. Our Government apparently won't let plain, honest, normal civilians come over but if a fellow comes along who wants to investigate some monstrosity then half the Senate, one half of the House of Representatives, and a number of the executive give him cordial letters. Now there are many things that I don't know but it has been my fate to have a pretty extensive acquaintance with cranks of every description in the United States ... I know them, nearly all, from past experiences and now just for the sake of keeping the world as quiet as possible $I$ have to give them time here far out of proportion to their value ... Now, out of your great wisdom, I wish you could explain to me why the deuce we let this crew come over here instead of sending a shipload of perfectly normal, dignified and right-minded gentle-men. These thug reformers-Baker will be here in a day or two and if I can remember it I am going to suggest to him that he round them all up and put them in the trenches in France where those of them who have so far escaped the gallows ought to be put. ${ }^{40}$

Page's penchant for the melodramatic notwithstanding, he amplified a broader anxiety among nationalists in the US about the prominence of progressives who moved out from the US and across Europe into international peace groups around the early days of the war.

While much of this was perhaps a generational Victorian critique of the modernist edge of some parts of progressivism that people like Page could scarcely tolerate, much of it was also rooted in a specific account of how internationalism ought to be connected to American nationalism. Like Roosevelt's warning of the "professional internationalist" in his writing during the war, there was a deep distrust of any variant of liberalism that did not place American exceptionalism at the centre of plans for international order.

\footnotetext{
${ }^{40}$ Walter Hines Page to David F. Houston, 23 March 1918, Walter Hines Page Papers, Houghton Library, Harvard University (emphasis added). (Hereafter referred to as Page Papers).
} 
The internationalism of progressives like Balch or even the apostate socialist Lippmann was itself radically different. Like many of the Americans who called themselves internationalists during the war, these people tended to see the label as shorthand for greater global integration of people, economies, ideas, and cultures. It was, in other words, more of a variation on cosmopolitanism, more of a critique of the essentialism of the ethnic nation, and a defence of the "cultural pluralism" promoted by Horace Kallen and Randolph Bourne. This, by definition, was a conception of internationalism at odds with the "interests" of a warring state.

However benevolent and disinterested Wilsonians purported to be, they could not avoid the fact that their internationalism had a chance to reshape global order only after they had mobilized the material and human resources of the United States, with its attendant claims to exceptionalism and homogeneity. Roosevelt's ally Albert Beveridge derided this as "motley internationalism," accusing it of joining the ranks of the professional and the political-class to create a deeply suspect belief in the possibility of an international organization that would not only reorder the global relations but also, in so doing, change domestic political ideology and identities. ${ }^{41}$ Arguing against such an encompassing social internationalism, David Jayne Hill, the historian and former Ambassador to Germany, wrote in the pages of the North American Review in 1919, that "the authority of international law rests on

\footnotetext{
${ }^{41}$ Albert Beveridge to William E. Dodd Papers, n.d. 1918 (box 13), William E. Dodd Papers, Manuscript Division, Library of Congress, Washington, D.C. (Hereafter referred to as Dodd Papers)
} 
nationalist character," and ought not to be based in some abstract cosmopolitanism that pulled sovereignty away from national interests. ${ }^{42}$ Attempts to order the world around notions of universal law, Hill worried, threatened to place the US at the mercy of European imperialism and the hundreds of small nations that would emerge in the post-war world. When faced with the prospect of a League of Nations, listening to conservative elements of Europe, Hill proclaimed: "For Europe entering the League is to maintain an alliance with America," while "for America the motive is the pacifist ideal." 43

Roosevelt took a similar tack in this period, equating progressive internationalists with idealistic naïveté and treasonously inattentive to the existence of other national interests with mal intentions:

The visionaries and enthusiasts among the internationalist leaders have been merely the tools of two evil beings: the brutish creatures who wished to destroy all government... and the astute sordid creatures who serve their own self interest by serving Germany...who find that the easiest way to render such service is to weaken their own countries...by breaking down the spirit of patriotism and nationalism under pretense of supporting internationalism. Don't trust the pacifists; they are the enemies of righteousness. Don't trust the professional internationalists; they are the enemies of nationalism and Americanism. Both of these groups appeal to all weaklings, illusionists, materialists, lukewarm Americans, and faddists of all the types that vitiate sound nationalism. ${ }^{44}$

\footnotetext{
42 David Jayne Hill, "International Law and Policy", North American Review 209 (1919), 324.

${ }^{43}$ David Jayne Hill, "In the Valley of Decision," North American Review 210 (1919), 25.

${ }^{44}$ Theodore Roosevelt, The Great Adventure (New York: C. Scribner's Sons, 1918), 76-77, 82-83.
} 
Well before the debates over the League of Nations covenant, American nationalists stoked scepticism about any thinker or political agent that did not place the preservation of American sovereignty at the center of their understanding of the world. Roosevelt further fuelled a distrust of this type of progressive by playing on deep cultural coding implied in gendered, raced, and anti-intellectual language. "Sissy socialists," "pink-tea and parlor Bolshevists," "make-believe reds," "weak-kneed intellectuals," "short-haired women" (alluding to suffragists and reformers), "thug-reformers," and "socialist cranks" were all among the many monikers levelled at the group of intellectuals and "professional internationalists" that he accused of "dilettante sentimentalism." Roosevelt effectively turned back on social scientists, who were easily portrayed as career internationalists, the same distrust of emotion, the distinction between a "detailed intelligence" and "desire" that had been used by social scientists to elevate their place into a privileged position in the peace talks. And it was impossible for the Inquiry, as it would be throughout those talks, to ignore such loud and prevalent cultural pressures. As an organization that was made up almost entirely of universitybased academics, many in the Inquiry realized that they would have to check dissent by policing membership and assuring that no "sentimentalism" or "desire" could be read into the organization. ${ }^{45}$

\footnotetext{
${ }^{45}$ Richard Hofstadter, Anti-Intellectualism, 211-213. For more on the politics of desire in Progressive circles see Christopher Lasch, The New Radicalism in America, 1889-1963.
} 
Having the Inquiry function at arms-length from the government helped it maintain some secrecy in day-to-day operations, away from the eyes of a political class still very much present in Washington. Yet just as news of the organization itself had leaked, information about who was working for it also made its way into the public sphere. Mezes, Bowman and Shotwell, each of whom had some authority to recruit for their respective research divisions, were particularly careful to distance themselves from any colleagues who might have been seen as "sentimental" or ideological in world-view. Krehbiel is an important example, in this respect, not because he was pro-German, nor because he was a pacifist or a rogue progressive. He was neither of which. He was however an easily recognizable liability for the Inquiry because of his acceptance of the intellectual distinction-akin to that proposed by Norman Angell-between an old pacifism (built around moral and religious principles) and the compelling nature of his "New Pacifism." In a review of Norman Angell's work, Arms and Industry, Krehbiel noted (before national sentiment began to turn against pacifism in early 1917) that the "new pacifism" was more closely related to the new idea of an "international polity" wherein war was no longer seen as "materially or morally" relevant to the aims for which the state exists. ${ }^{46}$ Krehbiel's place within the ranks of the bourgeoning group of "evolutionary pacifists" made him a liability. This group, which included Franz Boas, George Herbert Mead, E.I. Thomas, and

\footnotetext{
${ }^{46}$ Krehbiel, "The Relevance of War," The Dial, 1 September 1914,
} 
Veblen, would argue (in varying ways) that the teleological trend of progress was away from war, and therefore war was possible but atavistic and contradictory to the aims of civilization as a whole. ${ }^{47}$ Alongside his public affiliations with biological pacifists like Starr Jordan, Krehbiel's sympathies for the "New Pacifism" made him a risk in a group that was concerned in its early stages with concealing that it was at work on peace plans.

But, in addition to being excluded on ideological grounds, Krehbiel is also an important example because his exclusion points to how few of those intellectuals locked out of the Inquiry were ever actually officially rejected. Balch was a notable exception and likely only received a formal letter because of her persistence with Mezes. Instead of outward rejection on the grounds of suitability for directing state policy, access to the Inquiry was restricted through institutions that acted as self-policing intermediaries. In the case of Krehbiel, President Wilbur of Stanford University (his employing institution) reneged on the paid leave promised to employees that served in government during the war. When his application for leave appeared before the University Senate in December, he discovered that the university had received no "Government confirmation" that his responsibilities were in service to the state. Krehbiel and his close friend, former Stanford President Jordan, wrote to Mezes and Lippmann to press the matter but no final clarification appears to have ever been given. Instead Jordan and Wilbur

\footnotetext{
${ }^{47}$ For more on this see Paul Crook, Darwinism, War and History, 98-152.
} 
were told that "Dr. Krehbiel's work, (presumably in aid of Colonel House, whose peace mission was in the same letter alleged to have failed,) was really a private affair, not government service", meaning that Krehbiel could not receive a paid leave for his service and making further work with the Inquiry impossible. ${ }^{48}$ In this instance at least, the ambiguity of the Inquiry's relationship to official state apparatuses worked to the benefit of those staffing the Inquiry. The organization could demand secrecy, because its work was in the interests of the state, but it was often referred to and treated as outside of government, as a "private affair."

Contrary to what previous examinations of the Inquiry have implied, when it came to personnel there was rarely a clear line drawn between the information arriving from government officials, and those from civic groups, professional associations, universities, or philanthropic associations. And this ambiguity served its own purpose. When it became apparent that an applicant or candidate was a political liability there was often an intentional bleeding between critiques focused more directly on "scholarly equipment and bias," and those that focused on that candidate's politics or ideology. By early 1919 the progressive reformer and journalist William Allen White lamented that it appeared that the "incrusted old reactionaries" who had once been on the ropes in the Republican Party were now causing the wide scale collapse of progressive influence over state policy, and the failure to resist

\footnotetext{
${ }^{48}$ David Starr Jordan to Sidney Mezes, 2 February 1918 (box 1), Mezes Papers.
} 
such a collapse in the atmosphere of war revolved particularly around the question of "internationalism." ${ }^{49}$ The Inquiry was one of the critical sites where progressive liberals felt themselves increasingly marginalized by conservative liberals who saw the interests of the nation as the measure of a social theory's worth.

William E. Dodd, the American historian and head of the US data section for the Inquiry, early on sensed a change underway in the organization and wrote to Mezes with concerns that "reactionary elements" were emerging in the groups planning for peace; he hoped to raise the matter with House. Mezes replied on House's behalf,

I am sure that what you say with regard to certain reactionary tendencies and their danger has been very much in the mind of the Colonel. I am also sure that he would be glad to have you gather among other data all of the kind which would strengthen the hands of our government in maintaining liberal and forward-looking policies. ${ }^{50}$

And so it could work both ways. The group's executive wanted to preserve a space that was neither "reactionary" and excessively sympathetic to Europe (or at least British) imperialism, not "radical" and corrosive to the moral certitudes that underpinned its faith in America's mission. "Forward-looking" meant something to the progressive mind, but it was a carefully calibrated space that avoided both retrenchment and radical change. Forward-looking was consistent with the objective analysis of the evolution of human society

\footnotetext{
${ }^{49}$ Hofstadter, Anti-Intellectualism, 213.

${ }^{50}$ Dodd to Mezes, 31 October 1917 (box 12), Dodd Papers.
} 
whereas the radicals and reactionaries spoke only for the narrow interests of their species. Professionally enforced screening, or ideological disciplining, was not simply structured so as to keep "radicals" or "pacifists" out of the Inquiry. Rather, the administrators of the Inquiry and those who made it "in" to the group were very careful to build that organization away from any potentially dissident methods or characters that might challenge a particular reading of American state interests as the preservation of sovereignty in a post-war peace. While progressive liberals and social democrats had hoped that their support for the war would help them secure a place in developing a peace plan, Lippmann would be the only major figure from what could broadly be conceived of as a "political left" brought into the organization.

This is not to say that others did not try, or did not hope they would be asked to work for the Inquiry. Thorstein Veblen and John Dewey were widely recommended as representatives by the left. As the well-known editors of $T$ The Dial, they knew that the Inquiry existed and what it was for. And yet, despite public calls and private efforts to joining the group, they too were locked out. Veblen continues to evade easy intellectual and political classification among historians. But most agree that he made a career of thumbing his nose at established political culture and convention. Some have emphasized Veblen's institutional economics and Victorian socialism, noting his illiberal calls at the end of the war for the abolition of private property interests and individual 
profit. ${ }^{51}$ Others, such as Morton White, have argued that Veblen must be philosophically understood. He should, that is, be seen as part of the "revolt against formalism," which White tied to the influence of German historicism and "cultural organicism", and which bound together many of the left-liberal and socialist intellectuals in the Progressive Era. White rightly notes that despite some important differences, anti-formalists "call upon social scientists in all domains, ask them to unite, and urge that they have nothing to lose but their deductive chains." 52 Veblen's attacks on formalist concepts such as the nation, the state, and international peace, simply did not resonate with the Inquiry.

Veblen cannot, of course, be defined as a liberal. His advocacy for a non-Marxist socialism made him, as Dorothy Ross put it, a "true outsider."53 This status partly stems from the difficulty historians face in placing him in conventional disciplinary boxes, or situating him within the historical narratives of disciplines as we now know them, but it also mattered in his time. He made significant and highly original contributions to sociology, history, economics, anthropology, and political economy. Perhaps more than most of his contemporaries, he was the consummate social scientist, coupling an almost positivistic faith in anthropological and evolutionary conceptions of human development with an astute sense of socio-cultural power. He used this

\footnotetext{
${ }^{51}$ Sydney Kaplan, "Social Engineers as Saviors: Effects of World War I on some American Liberals," Journal of History of Ideas 17 (1956): 347-348.

${ }_{52}^{53}$ Morton White, Pragmatism and the American Mind (New York: Oxford University Press, 1975), 42.

${ }^{53}$ Dorothy Ross, Origins of American Social Science, 212.
} 
to reject what he called the classical economists' "addiction to natural law," that is, the attempt to reduce human behavior to individual and singular causes rather than cultural-institutional context. ${ }^{54}$ It is my sense that it was precisely this distinction between observing human behavior as guided by some immutable natural forces, versus seeing it as culturally situated (in the anthropological sense) and adaptive to forces that can be seen in particular institutional-power alignments, that gets to the heart of why Veblen was not welcomed in the Inquiry (aside, of course, from his abrasive personality). ${ }^{55}$

In his 1917 book, The Nature of Peace, Veblen argued that one should not see the development of liberal-democratic governments as "an unavoidable deliverance of common-sense" but as a particular "species of government" that "answered to an acquired bias, not to an underlying trait of human nature; a matter of habit, not of heredity."56 Government and its institutions were, for Veblen, an evolutionary development in an anthropological rather than biological sense. The state might try to convince itself of the universality its own institutional system and reasons for governing a particular way. It might use ideas of natural liberty, as Veblen says the English speaking people of the world did, to propose that particular institutional formations were the embodiment of a cosmopolitanism that could bring order to the international if it was only internationalized. But, for Veblen,

\footnotetext{
${ }^{54}$ White, Pragmatism and the American Mind, 55-62; Ross, Origins of American Social Science, 211.

${ }^{55}$ For an account of Veblen's role in the Inquiry see John P. Diggins, Thorstein Veblen: Theorist of the Leisure Class (Princeton University Press, 1999), 189-191.

${ }^{56}$ Thorstein Veblen, The Nature of Peace (New York: Transaction Publishers, 1917), 11.
} 
the nation-state was really just a collection of civic, bureaucratic, and commercial interests that historically built their power around lingering feudal anxieties over the security and "preparedness" of the state. Sidney Plotkin summarized Veblen's views of the state this way: "Whatever their other institutional differences-and Veblen certainly believed that in some respects the differences matters a lot-the early $20^{\text {th }}$ century Dynastic and Democratic states were nonetheless 'divergent variants' of a common feudal ancestor." 57

The ability to use this tribalism to uphold a balance of peace in Europe mostly worked for much of the early history of nation-states, but the rise of imperialism revealed that commercial interests once hedged in by these boundaries were spreading to all corners of the globe via improvements in technology and communications. This process, tied to the emergence of modern capitalism, "began to neutralize the geographical quarantine which had hedged about these communities that these communities were content to leave well enough alone." 58 The "fear of aggression" in this interconnected world meant that the accumulation of increasingly large armaments have "been conventionally accounted defensive," integral to the protection of the nation and the preservation of its sovereignty. Importantly, for Veblen, the presence of the state was not something that could simply be eliminated over

\footnotetext{
${ }^{57}$ Sidney Plotkin, "War and Economic Crisis: What Would Veblen Say?" Society 47 (2010): 240-245.

${ }^{58}$ Sidney Plotkin and Rick Tilman, The Political Ideas of Thorstein Veblen (New Haven: Yale University Press, 2011), 17.
} 
time. Still, it was a historical and anthropological phenomenon, not a natural or inevitable one, inseparable from local or provincial interests.

Moreover, for Veblen, the Great War revealed that any claim that universalizing a certain state structure might help create a cosmopolitan community was simply ignorant of the feudalistic (indeed "barbaric") dependence of any nation-state on "national honor" and "patriotism" to stoke tribalism. ${ }^{59}$ Like other social scientists, Veblen adopted the notion that "the preservation of the present pecuniary law and order" was "incompatible with an unwarlike state of peace." A legal system built on the principles of the old order would only formalize that system and further entrench it. But Veblen quickly found himself on the outside of liberal circles, especially with those who would make up the Inquiry, when he added that "incidents of ownership and investment," and "the current scheme of investment, business, and sabotage" depended on maintaining national insecurity and sovereignty that would "keep national animosities alert."

To say that Veblen's ideas were subversive does not do justice to just how much they threatened the conception of the state and the purpose of sovereignty within the variant of liberalism that came to dominate the Inquiry. Veblen, Plotkin argues,

defined the modern state not in terms of its compliance with corporate pressure, but in terms of its capacity to threaten use of force. It is, he said, an "enterprise of intimidation." The state

\footnotetext{
${ }^{59}$ Ibid., 29-31

${ }^{60}$ Ibid., 366
} 
was, for him, above all an institution of power, not an economic institution, and it is not always or necessarily even obedient to economic forces. ${ }^{61}$

Thus, far from seeing government as a bald tool in business interests, Veblen offered a comprehensive account of the international system rooted in a deep scepticism of any treatment of the nation-state as an ahistorical or acultural phenomenon. Like others of his generation who fell vaguely under the influence of Pragmatism, Veblen saw the international order as a sort of sociological system of interaction where "a modern nation constitutes a State only in respect of or with the ulterior bearing on the question of international peace or war." 62 The wayward movements of one nation-state could fundamentally change the sociological network to which they belonged, potentially even breaking the historical interconnection between liberaldemocratic states and the unconscious protection of national commercial and financial interests.

Despite his very public claim that liberal internationalism was evermore interchangeable with financial internationalism, and that these interests benefited from the sustained capacity of states to make inter-state wars, Veblen was asked by Shotwell to write several pieces for the Inquiry. ${ }^{63}$

\footnotetext{
${ }^{61}$ Plotkin, "War and Economic Crisis," 240-245.

${ }^{62}$ Veblen, "Suggestions Touching the Working Program of an Inquiry Into the Prospective Terms of Peace," reprinted in Joseph Dorfman, "Veblen on the Nature of Peace," Political Science Quarterly 47 (1932): 185-203.

${ }^{63}$ Veblen, "Outline of a Policy for the Control of the 'Economic Penetration' of Backward Countries and of Foreign Investments," n.d. Records of the Inquiry, Document 595, Records of the American Commission to Negotiate Peace, Record Group 256, National Archives at College Park, College Park, MD. (Hereafter referred to as Inquiry Documents NARA).
} 
The first of these, "Suggestions Touching the Working Program of an Inquiry Into the Prospective Terms of Peace," submitted early in 1918, argued that those charged with making peace faced two possible paths. The first was a diplomatic peace around the "eight greater Powers" on an equal footing, and the second was "a league (federation) of the pacific Peoples on a footing of national disclaimer." He argued that in the former arrangement, any plans for peace would not be able to have any interest in the internal policies of Europe and "the range and purpose of this Inquiry would therefore, in that case, be chiefly confined to questions of domestic policy and of maritime trade." On the other hand, he argued that a pacific league would extend the "range of this Inquiry...to all countries and peoples concerned." It was Veblen's hope that the Inquiry would reach out to the public and present it with a "two sided division of opinion" so that "spokesmen of the vested interests" were "found opposed to the spokesmen of a resolute maintenance of the peace at the cost of any necessary revision or adjustment within this established order." But, he argued, "it would appear that the Inquiry, following the apparent inclination of the Administration, should presently ... find itself searching for feasible ways and means of assuring the domestic tranquillity even at the cost of any contingent derangement of the established scheme of vested rights, whether private or national." 64

\footnotetext{
${ }^{64}$ Ibid.
} 
By the time Veblen submitted a second piece to the Inquiry, this one on "Controlling the Economic Penetration of Backward Countries and of Foreign Investments," he started to hold out hope that the Inquiry would move beyond the "recently past time when statesmen still placed their dependence on the Balance of Power," when it was "an accepted principle underlying all effectual statecraft that no people could hope to be collectively fortunate without being nationally formidable." While he did not embrace much of the American exceptionalism that the Inquiry would take on, he certainly saw a special role for the social scientist in providing a rationale and international network of governance that moved beyond the nation by vesting power into an administrative class with no national allegiance:

It is even yet a safe generalization that no modern nation would be ready now, out of hand, to disclaim or disavow all such interests and pretensions, tangible and intangible, commercial and patriotic, even after the national integrity had been duly safeguarded. Therefore it is presumed that the compact, league or coalition of peoples for keeping the peace, which is expected to be set afoot in the terms of the settlement, will take the line of mutual concessive disclaimer and disallowance of such usages, claims and pretensions...It appears necessary, by way of a definition of premises, to indicate at the outset with what scope and manner of jurisdiction the League is here conceived to be invested, in so far as bears on the question in had (economic penetration). Adequately to control such "economic penetration", the pacific League will have to be vested with a relatively very large discretion; which in turn implies an extensive surrender of powers on the part of the associated peoples of the League. ${ }^{65}$

\footnotetext{
${ }^{65}$ Ibid.
} 
Veblen imagined that the Entente nations could "incline to discard, or at least disregard, distinctions of nationality, so far as the sentimental preconceptions of its constituent peoples will allow."66 By dissolving these great power rivalries, their colonial territories, and nations once contained in the Central European empires would be administered as the US administered its territories in the lead up to their acquisition of statehood. These lands would be gradually offered the opportunity to join the international fold as they proved their ability to self-govern. But rather than allowing financial relationships to form the basis of international community, Veblen suggested that all administration of former belligerent nations and the colonial holdings of Entente and Central powers alike be overseen by the new league, and "quite unreservedly" on behalf of these "backward areas". If one did away with national rivalries by creating an administrative capacity within a league that refused to treat resources "for private gain, not for public use," the needs of the population of league nations could be met, Veblen argued, and the international rivalries of the world would melt away under sound management. Only under those conditions could the spread of civic culture impress upon these unincorporated nations the benefits of integration.

Despite his initial optimism, by 1918 it was apparent to Veblen that the peace was sliding into an increasingly nationalistic framework. He publicly

\footnotetext{
${ }^{66}$ Veblen's use of the word sentimental is important. With this assessment, he effectively inverted Theodore Roosevelt's attack on social scientists, arguing that it was actually his nationalistic attachments that were sentimental, not the more rational aspirations for a cosmopolitan international.
} 
bemoaned that it was proof of just how "far are men still bound in the ancient web of international jealousy and patriotic animosity." ${ }^{67}$ To add insult to injury, requests that Veblen be brought into the organization were pressed by the Inquiry's director of economics, and former student of Ely and Turner, $A$. A. Young. While Lippmann had courted Veblen and solicited the reports, Young's request was eventually rejected (at about the same time that Lippmann was being pushed out of the group) on the grounds that he was "too expensive," though it would have been quite apparent to Young that both staff and the budget available to the group were growing at a rate that could have easily afforded to hold Veblen. ${ }^{68}$ It was a peculiar argument given that there was no conversation or concern in the Inquiry's administrative files expressed about costs or overruns even while its numbers multiplied. To make sense of Veblen's informal rejection from the Inquiry we need look no further than the many other prominent intellectuals who were locked out of the Inquiry after writing preliminary reports which challenged the centrality and cohesiveness of nationalism in the coming peace.

John Dewey suffered this fate. Initially contacted by the Military Intelligence Bureau to write a piece on the "Polish Question" for them, Dewey submitted two short reports on Polish-American opinion after several meetings with the Bureau in Washington, and after a sociological investigation

\footnotetext{
${ }^{67}$ Veblen, "The War and Higher Education," The Dial, 18 July 1918, 46.

${ }^{68}$ Mezes to Young, 8 February 1918, Mezes Papers. For the connection between Lippmann and Veblen see Diggins, Thorstein Veblen, 189-191.
} 
of the Polish community in Philadelphia. ${ }^{69}$ There has been much debate about what this particular document meant to communicate to policy makers in the Wilson administration. ${ }^{70}$ Regardless of his intentions in writing the "confidential work", the report was not meant exclusively for the Intelligence Bureau, as some have implies, but was also directed at the Inquiry, which Dewey knew of through his ties to The New Republic and The Dial, and through his close personal relations with Croly and Lippmann. In a memorandum for Mezes, received in July 1918, Dewey proposed that the committee of Polish nationals who fled Russian-controlled Polish regions for Paris during the Bolshevik Revolution, and who claimed to represent the Polish people in their capacity as "the Paris Committee," were actually imperialistic, conservative, and anti-Semitic. Dewey argued that if Wilson's Fourteen Points' call for a Polish nation-state were taken on by the Inquiry, "it must of course be conducted through channels not subject to the prejudices which have already been skilfully worked up by the reactionary group in order to discredit the Polish liberal and democratic group." ${ }^{11}$ Dewey was concerned that the Polish Democratic Republic (the K.O.N.), a group based in Austrian-controlled areas of Poland and supportive of the relatively tolerant Austrian government at the opening of the war, were being unfairly painted as

\footnotetext{
${ }^{69}$ Dewey to House, 23 August 1918, Inquiry Documents NARA.

${ }^{70}$ For the contours of this debate see Charles Zerby, "John Dewey and the Polish Question: A Response to the Revisionist Historians," History of Education Quarterly 115 (1975): 17-30.

${ }^{71}$ Dewey to Mezes, "Memorandum for President Mezes Submitted by John Dewey," 19 July 1918 (box 3), Mezes Papers.
} 
pro-German because of this initial support. Dewey worried that AmericanPolish leadership that had the ear of the administration-and possibly a wider constituency-was closer in ideological orientation to the conservative Paris Committee. He privately worried that, in turn, the Paris Committee was using their connections to American officials, and conservative Polish publicists based in Washington, to earn the "power to determine what persons among the non-naturalized Poles should have the stigma of enemy aliens removed and who should not." 72 This aimed to effectively silence a substantial minority of radical Poles in the US, but they appear to have had no effect.

Dewey had hoped that his questions would spur a proper investigation of the Polish question in the US and abroad. He wanted his government to understand that ethnic nationalism was not simply a traditional identity but was only fully enlivened by a democratic and pluralist political organization. Dewey also worried that formal recognition of the Paris Committee as the sole representative of the Polish people, would actually threaten the appeal of Wilsonianism in other parts of the world where the restive masses were pinning their hopes on a new social order within and between nations. "President Wilson's policy," Dewey told Mezes, "has no stronger and more intelligent supporters anywhere than precisely this group now discredited, and this fact can easily be proved to any Americans." If the government were to recognize the Paris Committee as the embodiment of Polish nationalism,

\footnotetext{
${ }^{72}$ Ibid.
} 
Dewey warned, "such action will be hailed by every reactionary element in this country and Europe as a successful undoing in one very important detail of the general principles of world reorganization laid down by President Wilson." 73 If Wilson's call for self-determination and the scraping of old imperial systems were to mean anything, Dewey felt, it had to address the claims of the "more radical" group of Poles. Their platform read like a manifesto of progressive ideals shared by social democratic elements throughout the war-torn world: direct secret suffrage, equality of all citizens regardless of sex, race, nationality, and religion, an eight hour work day, equal pay, and the gradual socialization of the means of land, transportation, production and communication. These, Dewey believed, were most commensurate with the new international that managed a balance between labour and capital. ${ }^{74}$

Dewey's study was put in the Inquiry's files, along with 42 other reports by well-respected scholars, and any expertise it rendered was promptly forgotten. Again, the conditions of this "forgetting" of Dewey's work are helpful in highlighting the ideological parameters that emerged in the Inquiry. The Inquiry was surprisingly successful at finding "qualified staff" when it came to staffing the Eastern European division with experts in culture and history. Among two of the experts charged with examining the Polish Question were Henry Arctowski and S.J. Zowski, both Polish nationalists who

\footnotetext{
${ }^{73}$ Ibid.

${ }^{74}$ Dewey, cited in Charles Zerby, "John Dewey and the Polish Question," 20.
} 
immigrated to the US earlier in the century and were likely citizens. ${ }^{75}$ With close connections to the Paris Committee President Ignace Paderewski, Arctowski was actually feeding both the Inquiry's instructions and his division's recommendations to the leadership of the royal nationalists in the US.

The Paris Committee was quick to use this "secretive" information to campaign for the expansion of their nation's boundaries by applying pressure on the President and House, and building propaganda campaigns that emphasized the importance of Poland including, for example, regions that gave the state access to the Baltic Sea. ${ }^{76}$ Gelfand believes that the Inquiry seemed to "strongly" support "the territorial claims of the Polish nationalists," including some to parts of Lithuania. The consistent openness to Polish territorial demands reveals, he continues, "ethnic self-determination was applied wherever the principle could serve to enhance Poland's territorial interests," but when economic, political and historical arguments "tended to support the Polish claims, these arguments were advanced."77 This is not to insinuate that the Polish royalists in the Inquiry were directly responsible for burying Dewey's report. They would have likely seen the report, but were not in a position to decide on whose desk it would land. But from what we do know, the claims made by Polish conservatives were well received. It made it

\footnotetext{
${ }^{75}$ Gelfand, The Inquiry, 52, 203-205

${ }^{76}$ Ibid., 206; Louis Gerson, Woodrow Wilson and the Rebirth of Poland (New Haven: Yale University Press, 1953), 96-97.

${ }^{77}$ Gelfand, The Inquiry, 206-207. Emphasis added.
} 
easy to overlook an American assessment, like Dewey's, as ideologically motivated by a domestic progressive agenda. Dewey's suggestion that K.O.N be listened to may not have sat well with the Eastern European Division of the Inquiry, much less the Polish division; other aspects of his report likely irked them too. As a group that openly advocated the socialization of land and elements of the means of production, as well as progressive income taxation, universal suffrage, equal pay and citizenship, the K.O.N. embodied what were still considered "radical" tenets, which were easily found in Dewey's other work. Many of the Inquiry's recommendations, including the union of Lithuania to Poland and granting Danzig "free-city" status rather than placing it under direct Polish sovereign control, reflected a gradual move in the organization toward top-down methodologies that allowed the organization to represent nations in the simplest of ways. This meant privileging "local knowledge" in cartographic and ethnological representations, even when it ignored many unsettled questions around political, linguistic, and ethric division, and the complex interconnection between the political and cultural influence of diasporic populations in the US and the sovereignty claims of "local" elites looking to gain or hold on to status in Europe and throughout the Southern Hemisphere. ${ }^{78}$

Like Dewey, the well-respected Chicago-based sociologist W.I. Thomas understood that socio-cultural, political, historical, and economic data

\footnotetext{
${ }^{78}$ Zerby, "John Dewey and the Polish Question: A Response to the Revisionist Historians," 17-30.
} 
were malleable things. By 1917, Thomas had already made an important professional name for himself by questioning dominant American assumptions that race and ethnicity determined the possibilities and capacities of an individual's social existence. Along with Florian Znaniecki, Thomas co-wrote the still canonical sociological study, The Polish Peasant in Europe and America. That work, like Balch's study of Slavic culture in America and Europe, used copious amounts of qualitative, ethnographic observationsgathered through on-the-ground fieldwork-of a culture both in the US and in the "home-country," to arrive at a generalizable sociological theory about the influence of environment on behaviour and custom. Like Balch and Dewey, Thomas spent important and formative time working closely with the reform movement that developed around Hull House in Chicago-the famous settlement house founded by Jane Addams to serve as a hub for reform on issues of poverty, race, and immigration. Like many of the men and women who bridged the gap between Hull House, an incubator for progressive reform, and the academic world of disciplinary sociology, Thomas became an integral figure in what came to be known as the "Chicago School" of sociology. Like other early figures in this school, Thomas's work was deeply indebted to his experience with reform movements like Hull House, writing directly on contemporary social problems, and especially focused on scientifically understanding and aiding social integration of new Americans. ${ }^{79}$

\footnotetext{
${ }^{79}$ Mary Jo Deegan, Jane Addams and the Men of the Chicago School, 1892-1918 (New York: Transaction
} 
Thomas was part of an important movement, then, that believed social science could play a critical role in "carefully studying and reporting on the consequences of various social-organizational patterns and institutional configurations," observed through ethnographic fieldwork, a method gleaned from anthropological studies of "foreign cultures."

As Thomas showed in his work on the Poles in America (published between 1918 and 1920), there was a complex interplay between, on the one hand, domestic American conceptions of what constituted nationality (in the theoretical sense), the meaning and value that many Americans ascribed to various nations (for example a deep sympathy for Polish nationalism but little interest in Egyptian nationalism), and how foreign groups and individuals reacted to the situation around them, and on the other hand the process of presenting data that fed into or pushed-back against these other impressions. Thomas's work developed a highly pragmatic and social-psychological notion of human behaviour that proposed that "the context for social action is always a situation," and it is how the qualities "are subjectively understood that has

Publishers, 1990), 116-140.

${ }^{80}$ Craig Calhoun, "Sociology in America: An Introduction," ed. Calhoun, Sociology in America: A History (Chicago: University of Chicago Press, 2007) 15, n. 34; 193. I take seriously Andrew Abbott's point that one must be careful not to ascribe cohesiveness to the "Chicago School" that did not exist in its own time. However, taken as an institutional site and event the Inquiry demonstrates that these loosely affiliated individuals were methodologically similar in important respects, not least in their reading of the plasticity of nationality and the customs and culture others saw as fixed to race, ethnicity, language and even geography. But the Inquiry also somewhat modifies the observation by Calhoun and others that, "Chicago sociology was less engaged with the state and high-politics and with structural economic questions," and "more engaged with locally acting groups." The Chicago School, and the pragmatists that influenced it, saw locally acting groups as part of a larger global, interconnected system in which the nation played an important symbolic role informing the conditions of situations. That was certainly how Jane Addams saw it. 
the greatest impact on the actor's response." ${ }^{81}$ Balancing an ethnographic method with a search for generalizable theory made for a particular brand of sociological praxis, which made Thomas an acknowledged pioneer in gender, youth and race, very well connected and respected among professionals and reformers alike.

Not surprisingly, then, Thomas was asked to write a report for the Inquiry in its preliminary period, on the question of the shape of internationalism in the post war world-and not on the Poles, his major field of expertise since 1913. He submitted a substantial paper, entitled "Nationalism, Individualization of Function, and the Creation of Value," that attempted to argue that anyone looking at postwar international order would have to explore the balance of nationalism and individualism, "judged from the standpoint of their efficiency as instruments for the creation of values (happiness, economic gain, etc.,)." 82 Thomas outlined what might be characterized as a symbolic interactionist vision of international relations. Following the father of Symbolic Interactionism, his friend and colleague at Chicago G.H. Mead, Thomas proposed that nations functioned much like individuals. They acted towards other nations on basic psychological impulses such as enmity, rivalry, and interdependence, and their actions depended on the meaning and reading of those things within that particular

\footnotetext{
${ }^{81}$ Neil Gross, "Pragmatism, Phenomenology, and Twentieth Century American Sociology," in Calhoun, Sociology in America, 194.

${ }^{82}$ W.I. Thomas, "Nationalism, Individualization of Function, and the Creation of Value," Report for the Inquiry, 1918 (doc. 270), Inquiry Documents NARA.
} 
culture. There are, in this interpretation, no universal or natural values that determine behavior or define the composition of nations. There was no fixed progression built into human nature or societal development that inevitably steered a nation towards one particular type of state formation (or non-state social alignment, for that matter). Thomas's submission argued that nations, cultures, and societies could only be understood as "a value for another society," and were therefore measured through the lens of one's cultural experience and expectations. As such, attempts to map out nation-states into neat containers, using little more than a mixture of geological and cultural indicators, risked perpetuating the idea that distinct and durable cultural identities could be preserved timelessly and contained to a specific territory. Environmental or geographical placement had some impact on social formation, Thomas confessed, but cultural affiliations were not wholly determined in any fixed way by blood, language, biology and space; rather, culture was at least partly semiotic or symbolic, and therefore sensitive to the actions of wilful agents. It could aggravate isolation, or it could encourage increased interdependence at the level of the individual and nation.

Man is not indigenous to zones, but a migrant to them; his nervous organization is essentially the same the world over; he is a man. But culturally (through his transmission of an identical body of tradition and the establishment of particular attitudes and values) a society characterizes it members profoundly. $A$ nationality, therefore, has represented and is destined to represent an area of cultural characterization ... In this way it performs for the world-organization a function corresponding to the individualization of function among its members. The 
values developed by a given nationality may then be appropriated-borrowed, imitated, incorporated-by another society, or they may be neglected; but no group should compel another group to accept its values. ${ }^{83}$

Thomas approached the question of world organization with the same anti-foundationalism he used to approach questions of gender, sex, race and age. As he argued with education ten years earlier, society and its values could serve as a constraint or an enablement in efforts to educate children in new values. The choice of what values to teach was clearly within the control of a culture. So to assume that all children in all societies, like all nations, ought to be evolving along parallel trajectories determined by a fixed natural principle of evolution, was to ignore the basic fact that development of the individual was as or more fixed to accumulated knowledge in a social unit. Thomas later argued in "The Comparative Study of Cultures," that "diversities in behavior and culture," be they the education of youth or the concept of interests said to guide the state, "are the result of different interpretations of experience, resulting in characteristic behavior reactions and habit systems, and that a uniform course of cultural and behavioral evolution is consequently out of the question." 84 There was a circularity here that needed to be understood, but from within an assertion of the fundamental agency of the individual-as-expression-of-social-action. That is, the individual mind, and the culturally-developed forces of habit which structurally condition individual

\footnotetext{
${ }^{83} \mathrm{Ibid}$.

${ }^{84}$ W.I. Thomas. "The Comparative Study of Cultures," American Journal of Sociology 42 (1936): 177-85.
} 
development, transform values-not in any "biological sense, but only in the sense that the attention and the content of the mind are made correspondent with the world as it is presented." ${ }^{85}$ In this respect, Thomas believed that the behavior of nations was not dictated by invariant national interests that were naturally or structurally determined. Rather, arriving more gently at the same conclusion as Veblen, Thomas proposed that the values of a society "were a matter of habit," and while no less real for it, the habits of a nation could be steered towards particular value-based outcomes.

It appears that Thomas's report was filed for use. Not long after, Shotwell wrote to Dodd, also at the University of Chicago, asking him to meet with Thomas, who was to leave on December 21, 1917 to join the Inquiry. "I suggested that he get in touch with you before coming east," Shotwell told Dodd, "so that although his field only touches yours at a somewhat distant angle, he may be informed as to the situation as a whole." ${ }^{86}$ For the moment it appeared that Thomas had made it in to the organization. Yet three months after what would have been his first visit to the Inquiry's Geographical Society Office in New York, newspapers in New York and Chicago reported that Thomas had been arrested in a Chicago Hotel with a younger woman, the wife of an officer serving overseas. The timing of the arrest remains suspect, as

\footnotetext{
${ }^{85}$ W.I. Thomas, "The Province of Social Psychology," American Journal of Sociology 10 (1905): 454-455.

${ }^{86}$ Shotwell to Dodd, 16 December 1917, Dodd Papers.
} 
does the trumped-up nature of the charges. ${ }^{87}$ To make matters worse, while defending himself in the press and the court (on charges that were later thrown out), Thomas was summarily fired by the University of Chicago, shattering his career at the mature age of 55. For the wider public, Thomas's work came uncomfortably close to moral relativism, and the bigger story was of a professor who identified his research on marriage and sex as "radical" finding himself caught up in a sex-scandal that could not be ignored. ${ }^{88}$ It seemed that Thomas was falling victim to what would become his most famous dictum: "If men define situations as real, they are real in their consequences." 89 Realizing that opinion was against him, Thomas's defense, published in the Chicago Tribune, was furious that a sex scandal had been

\footnotetext{
${ }^{87}$ Robert Throop and Lloyd Gordon Ward, "W. I. Thomas and the Suffragists." Toronto: The Mead Project (2007) http://www.brocku.ca/MeadProject/Scrapbooks/Circulation/Thomas_and_the_suffragists.html (accessed 22 March, 2012)

More work on this connection remains to be done. But, as Throop and Ward note, historians have generally accepted that tip-offs by the FBI, who likely had Thomas and his wife (a well known pacifist and secretary of the Women's Peace Party) under observation, led to their arrest by local authorities. The transgressions of Thomas and his wife were already well known, and his arrest under newly minted Chicago vice laws presented the perfect opportunity to air them all. A scandal erupted in Chicago that dragged Thomas into Morals Court for the violation of the Mann Act, which forbade the transport of women across state lines for "immoral purposes," and for false hotel registration. The media pounced and quickly pointed to a number of damning facts: Mrs. Thomas was one of the "founders of the Woman's Peace Party"; the age difference between Thomas and Mrs. Granger, the woman he was caught with, was considerable; Mrs. Granger's husband was soldiering overseas; Mrs. Granger had a three year old child living with her mother in Forth Worth, Texas; and, perhaps most importantly, W.I. Thomas had used lectures and publications to attack the institution of marriage and, as it appeared to many, defended promiscuity. As is often the case, immoral personal behavior was treated as causally related to one's "radical" political causes, helping to discredit both. For a recent use of this narrative see Calhoun and Gross, Sociology in America: A History, 15, 186. For articles on the scandal see the extensive coverage in the New York Times. "Couple Arrested in Hotel." New York Times, 13 April 1918, 18; Chicago Tribune. "'Dr. Thomas' and Woman Taken in Loop Hotel," Chicago Tribune 12 April 1918, 1; "To Resign?" Chicago Tribune, 14 April 1918, 8; "Dismiss Thomas from U. of C. on Judson's Order," Chicago Tribune 17 April 1918, p. 17; "Thomas and His Itty Bitty Lady in Court Today," Chicago Tribune 19 April 1918, p. 13. Chicago Tribune; "Thomas Defends Self As A Daring Social Explorer," Chicago Tribune 22 April 1918, 15.

${ }^{88}$ W.I. Thomas, “The Professor's Views," Chicago Tribune, 22 April 1918, 15-16.

${ }^{89}$ W.I. Thomas, "The Methodology of Behavior Study," in The Child in America: Behavior Problems and Programs (New York: Alfred A. Knopf, 1928), 572.
} 
allowed to destroy his professional life, but at the same time still tried to treat the situation as a teachable moment:

We are all aware that human relations are not what we would have them. We have a war, and crime and pauperism, and problems of labor and capital, and prostitution and revolutions, etc., and in view of this imperfect state of society it is the task of the social sciences to develop a method of determining social laws and their application which will give in the human world a control approximately as perfect as the control obtained in the physical world though the laws developed by physics and chemistry and in the animal and plant world through the study of biology. But the social sciences, have failed...in the social world we have developed no laws, and consequently social changes are not rationally made. When conditions become unendurable we resort to prohibition, sabotage, new legal enactments, revolution, and eventually to bolshevickism...it would be a bold man or a stupid one who would claim at the present moment satisfaction with his contribution...there has been a failure of intellectualism, and no one feels this more keenly than the intellectuals themselves.

Thomas was swept into the hysteria of social disorganization that he had spent most of his life analysing. He was "not guilty of this charge as it is understood," he therefore proclaimed, "but I am guilty of holding views and being capable of practices not approved by our social institutions." 90

While Thomas's intellectual views and practices on their own could have scared most social scientists away, it was the public scrutiny of his sexual transgressions which most frightened the men of the Inquiry. Dodd wrote to Shotwell asking if he had heard any news of the story, and after sometime

\footnotetext{
${ }^{90}$ Thomas, "The Professor's Views," 15-16.
} 
Shotwell replied that everyone had heard the news in New York. "You can guess how shocked we have all been." But, significantly, he was also quick to charge Thomas with even bigger crimes than mere vice: "I agree with you as to the moral implications in this whole thing and the fundamental disloyalty which it implies." 91 Thomas's writing on sex had already raised eyebrows several years before, but the negative attention largely fell off and his book, Sex and Society, went on to multiple publication runs. And certainly in 1917, it had not been enough to scare off the Inquiry from recruiting him. ${ }^{92}$ What had changed between the end of 1917 and the first months of 1918 was that Thomas now received an immense amount of public scrutiny because of the many unsaid cultural boundaries he crossed around patriotic motherhood, age differences, extramarital affairs, and notions of chivalry. It was not just that the sexual affair was personally disloyal, though some could doubtless have made the case. It was that the executive of the Inquiry knew that Thomas would bring such an intense scrutiny to the objectivity the organization had spent so long building by avoiding controversy, that it was easier to cut all ties and erase any record of his work. "Dr. Thomas has been doing no particular work on the Poles for us recently," Shotwell continued, "and is not

\footnotetext{
${ }^{91}$ Shotwell to Dodd, 8 May 1918, Dodd Papers (emphasis added). In an ironic twist that was lost on the historian, Shotwell noted "These things depress me very much, but they are part and parcel of the communities such as we have to live in," and penned in after the fact, "I mean the almost universal tendency of great city life, to disintegrate [illegible] bonds."

${ }^{92}$ For more on the fleeting controversy around his book, Sex and Society, see the Throop and Ward, "W. I. Thomas and the Suffragists."
} 
likely, I suppose, to be further connected with the Inquiry." With that note, Thomas's report, like Dewey's, was filed and forgotten.

The burying of these "radicals" is important in itself but the timing is also suggestive. By the summer of 1918 , when Bowman took over the as secretary of research on the executive, it was apparent that the initial emphasis on self-determination that Lippmann had given in philosophical tone to the Fourteen Points was being systematically gutted. Steadily and surely, the studies that were used by the Inquiry, the organization of its information, and the increased generation of geopolitical and geo-cultural maps, reflected a desire to equate stable national boundaries with what were felt to be definable and equally stable ethno-linguistic cultural identities. By mid-1918, the Inquiry came to embody what Erez Manela has defined as the Wilsonian "view that major social and political issues within American society [were] intimately connected to the global role he envisioned for it in the post-war world, as a model for international society." 93 The flattening of much of the socio-political and economic complexity of Europe was an attempt to envision a manageable international order.

Debates over whether nations should be minor agents or the core sovereign units of international order were just the beginning. There were deeper troubles, as the experts of the Inquiry's social scientific assumptions came to resemble already dominant cultural assumptions in the US about that

\footnotetext{
${ }^{93}$ Manela, The Wilsonian Moment, 33.
} 
nation's sovereign rights and role as a model for all nations to follow. The dominant social scientists in the Inquiry came to see that offering a vision of the world built around well-defined nation-states, made empirically evident through solidly structured territorial boundaries, meant avoiding substantial discussions about the fluidity or mutability of nationality as a concept. When Wilson commissioned a trusted group of experts to do the work of defining a new world order, he and House knew that granting this authority to social scientists would provide a critical distance between knowledge and government. But they also understood that this cadre of experts were professionally invested in maintaining the objectivity of the Inquiry, so much so that they had to stifle any controversy, be it over sympathy for labour, another nation's internal cultural imperatives, or, as it turns out, even public sexual transgressions. Thomas came to recognize that the war had had an effect on the imagination of social scientists, as much as the general population, pushing them into ever tighter social or professional units that presented a falsely united front in the service of maintaining their legitimacy. This, Thomas mused, "explicitly excluded any policy that might be regarded as in the least radical." $" 94$

\section{Conclusion}

These stories of secrecy, scientism, and dissent highlight how a particular notion of internationalism came to the fore of the Inquiry. It was formed

\footnotetext{
${ }^{94}$ Thomas, "The Professor's Views," 15-16.
} 
because its claims to social scientific objectivity, as disconnected from the state, created an apparent space between the state and society. It was well understood within the organization that a scientism built on inductive methods and an ontology of the nation-state that buttressed American exceptionalism was expedient, and would only ingratiate the Inquiry to the government and its composite interests. If intellectuals, no matter what their reputation or availability, availed themselves to the group, they still had to be willing to produce findings and speak in a language that did not risk division within the organization. Divisions would expose the extent to which the incipient social sciences were, in fact, still carriers of ideological, sentimental, or emotional currents. They would highlight the extent to which no objectivity in method could easily translate into uniformity (or universalism) in conclusion. Under those conditions, the epistemological certainty provided by their scientism risked falling away. And yet, the discursive distinction between legitimate, rational, or empirical social science on the one hand, and illegitimate, emotional, and ideological concerns on the other, cut multiple ways. The hope that one could sit outside the state and steer interests by appealing to scientific purity quickly buckled under the forces of its own puritanism. But not before spurring the abjection of non-academics, like Lippmann, who had been initially integral to the depoliticizing of American plans for peace, and to avoiding unwanted public scrutiny. Lippmann was a tremendous stylist, but he was also closely tied to activists. It was not because there was a complexity 
to these problems that only a trained social scientist could understand; it was the presumed content of the argument that was problematic.

Veblen's work for the Inquiry reveals that the group was not remotely interested in radical discussions of the gradual folding of nation-state sovereignty into a collective security system that checked national financial interests, and did not rely entirely on them as the glue that bound nations together. It was not that Veblen called for the wholesale elimination of nationstates. None of the Chicago thinkers locked out of the Inquiry were so utopian. Rather, his scepticism about the actual interests at play within states-those reactionary forces that sustained the reason of the state and primed the pump of atavistic tribalism when it suited their pecuniary interests-made him an obvious liability. Perhaps pushing Veblen out of the Inquiry could be anticipated. But Dewey's case is more peculiar. He had fought and, in the court of public opinion, likely won, a debate with Randolph Bourne on America's participation in the war in the first place (although, truth be told, he also had to muzzle Bourne in the end). He was hardly a disloyal element, however much he came to the defence of academic freedom at Columbia. His work for the Inquiry reveals, however, that his superiors quickly ignored the presence of multi-cultural states in the countries they wanted to define, especially social-democratic groups that fit the "radical liberal" label House had also slapped on progressives like Lippmann and the New Republic. On the one hand, a willingness to ignore sociological complexities for the sake of constructing an easily recognizable and well-ordered geopolitical system was 
fundamental to social scientists' ability to "reflect" society in a complex enough way. Their representations needed to be beyond general criticism, but also to steer clear of any variable, method, or conclusion that might have been seen as controversial in its overturning of general assumptions about American society, history and that nation-state's place in the world. But controversial methods and conclusions were usually the ones that proposed a rethinking of international order, and this would mean acknowledging an inevitable parochialism in any outlook, be it social scientific or narrowly political, as well as a deep interconnection between challenging domestic power structures and assumptions as the US worked to re-imagine the world. Instead of engaging with these criticisms, the core members of the Inquiry simply stifled them, and fought anything that might call into question the cohesiveness of opinion in the organization.

The paradox of a scientific research group trying to deliberately avoid internal debate in order to retain its social authority should not be lost. In this light, the distrust directed toward left progressives and liberals stemmed as much from an anxiety over public scrutiny. But this distrust was of anyone who would bring unwanted public attention to the work of the Inquiry, not just those who brought serious ideological differences in method and opinion. Perhaps nothing demonstrates this aversion to controversy better than the unceremonious dismissal of Thomas. Even though he was never convicted of wrongdoing, the taint of a moral scandal around a dismissed professor with ties to a much-maligned progressive community was enough for the members 
of the Inquiry to bury reports and eschew his highly respected research on ethnicity and cultural identity.

The rather odd selection of "experts" for the Inquiry that Lawrence Gelfand and subsequent interlocutors have identified was thus not simply the product of poor timing or the barriers that came from trying to maintain secrecy. The Inquiry was, like so many political secrets during war, a poorly guarded one. Though its daily dealings were mostly unknown, even to many of those working inside, there was certainly broad knowledge, even in Europe, about a think-tank working under House on postwar peace plans. House and his associates seemed prone to leaking information about their work at their convenience to try to draw in, or perhaps simply to impress, their colleagues. Yet, as a group, the Inquiry was repeatedly presented with experts in fields it badly needed, and it repeatedly turned them down on pretences of secrecy, and on conveniently conjured pretences of scientism. The result of this was an acute awareness of, and attempt to work within, the dominant and often interconnected American cultural discourses around class, nationalism, sovereignty, patriotism, gendered intelligence, and political ideology generally. This was not some vast and coherent conspiracy. If anything, it was much more nefarious precisely because of just how deeply embedded these assumptions were. 


\section{Conclusion}

Behind Institutions...lie the vital forces which call these organs into life and shape them to meet changing conditions." -Frederick Jackson Turner, The Significance of the Frontier in American History (1893)

That the State is a mystical conception is something that must never be forgotten. Its glamour and its significance linger behind the framework of Government and direct its activities. -Randolph Bourne, The State (1918)

If a history of transnationalism is to have meaning...it must explore the complex dialectic between exceptionalism and internationalism. Only this dialectic explains the enthusiasm among intellectuals-and academic historians no less-for the study of an American character on the one hand and an insistence on the interdependence of peoples on the other. -Ian Tyrell ${ }^{1}$

It is necessary to think of the political problems of intellectuals not in terms of 'science' and 'ideology,' but in terms of 'truth' and 'power'.-Michel Foucault $^{2}$

When word leaked that Woodrow Wilson's closest advisor had formed a committee to study war aims and terms of peace, the philosopher and liberal publicist Horace Kallen wrote with great optimism that Americans had an unprecedented opportunity to change the shape of internationalism by placing new expert minds at its core:

Diplomatists are by training, habit, and usage unfit for the particular service in hand. Servants of international conflict for exclusive national advantage, their skill is only in the arts of innuendo and dickering which such service demands. They would be as unsuited to a task requiring frankness and mutual accommodation as a pork-magnate to settle a strike in his own packing plant. The men needed are the men of international

\footnotetext{
'Ian Tyrell, "American Exceptionalism in an Age of International History," The American Historical Review 96 (1991): 1053.

${ }^{2}$ Michel Foucault, "Truth and Power," in Ed. Colin Gordon, Power Knowledge: Selected Interviews and Other Writings, 1972-1977 (New York: Pantheon Books, 1980), 132.
} 
mind, who have been studying these diplomatists in action, who are aware of the defects of the present state system, and who have thought out alterations and improvements. ${ }^{3}$

Like most, Kallen had suggestions of his own about who fit this bill. He offered up his colleagues, John Dewey and Thorstein Veblen, as best qualified to serve as experts on any international committee. Both had given the concept and conduct of internationalism a great deal of thought. And Dewey, perhaps most pointedly, proposed that the peace now imminent would necessarily be guided by what he called a "new social science".

[The] political and legal sciences rest upon the assumption of certain general and fixed conceptions which in the main the present static order exemplifies. Economic science regards the dynamic order of society as the result of the cumulative intelligence of an indefinitely large number of beings, each devouting [sic] his own intelligence to the things to which it is peculiarly adapted, namely the pursuit of interests which lie within personal control...but the war has shown that our existing social situation is in effect the result of the convergence of a large number of independently generated historic incidents. It has shown that our ordinary rationalizing and justifying of ideas constitutes an essential mythology in their attributions of phenomena to basic principles and intelligently directed forces. ${ }^{4}$

Like those Inquiry men who now toiled away in secrecy, Dewey was dubious of legalistic and political rationalizations of internationalism. But unlike those

\footnotetext{
${ }^{3}$ Horace M. Kallen, "The Structure of Lasting Peace: The Federalization of Sovereign States," The Dial, 28 February 1918, 180-184. Also see Lewis S. Feuer, "Horace M. Kallen on War and Peace," in ed. Milton R. Konvitz, The Legacy of Horace M. Kallen (Mississauga, Ontario: Associated University Press, 1987), 36. Importantly, Kallen never directly worked with the Inquiry staff or on the Inquiry knowingly, though he was solicited for isolated works in the early stages of the organization. The archives of the Inquiry at Yale and in the National Record and Archives in College Park show no documentation that he was ever inside of the groups that were formed by Sidney Mezes or Isaiah Bowman, nor that he was ever paid for his services. Kallen belongs to the ranks of those dissidents shown a glimpse of the Inquiry by always kept at distance.

${ }^{4}$ John Dewey, “A New Social Science," New Republic 14 (1918): 292-94, emphasis added.
} 
who travelled with Wilson to Paris, Dewey was additionally sceptical of any social science that attempted to replace the concepts at the core of legalistic or political norms (the state, sovereignty, nation) with a universalistic sociological internationalism. The latter, in Dewey's view, took new conceptual norms as universally applicable without understanding their use of information as "a technique of social control." Dewey imagined a world where instrumental rationality would be employed towards democratic ends-a world organized as an open and pluralist community, built (at least in part) around the principles of scientific inquiry and acknowledging the latter as the best source of knowledge and the most effective form for directing and conducting politics. "Unfortunately, there is much in the tradition of what is regarded as scientific sociology," Dewey warned, "which lends itself, unwittingly, to [...] base uses."7 It was not enough for Dewey to see an old guard and rationality be pushed out. He identified that social science could just as easily reify its concepts into new knowledge, which he saw as always provisional descriptions of shifting conditions-not essential and immutable properties of human society, but patterns of habit and experience held in place by a belief in them.

\footnotetext{
${ }^{5}$ John Dewey, The Middle Works of John Dewey, Volume 11, 1899 - 1924: 1918-1919, Essays on China, Japan, and the War, ed. Jo Ann Boydston (Carbondale: Southern Illinois University Press, 1988), xi.

${ }^{6}$ Robert Westbrook, "Pragmatism and Democracy: Reconstructing the Logic of John Dewey's Faith," in The Revival of Pragmatism: New Essays on Social Thought, Law, and Culture, ed. Morris Dickstein, Copyright 1998. (Durham: Duke University Press Books, 1998), 128-140.

${ }^{7}$ John Dewey, The Dial, 25 (1918), 381.
} 
Yet Dewey maintained a belief that social science, if critical, realistic and pragmatic, had the unique capacity to bind nations together, and social scientists to act as the sinew that would connect nation-to-nation, labour-tocapital, and disciplined intelligence to the masses. This was more than a case of intellectuals getting close to the power of the state. Dewey and the writers of The Dial who would never see inside the Inquiry were nevertheless confident that the war had awakened a new internationalism that positioned social scientists—via their privileged methods and comprehensive study-as critical to the very understanding and connectivity of society as an international space.

But lending legitimacy to the idea that a class of social scientific experts could expand beyond academic application and into the management of social and political affairs-so as to anchor these areas of human organizations to a rational foundation-created a trap for those social internationalists who imagined a scientific democracy while also supporting American intervention in the war. Maintaining that the war provided an opportunity for democracy and liberalism internationally, Dewey claimed that the forces that lead to war could be ameliorated if a critical social science treated democracy and liberalism as outcomes that were, in true philosophical pragmatic form, never completed. The war showed, Dewey argued, that it took a "detailed intelligence, not mere desire, however praiseworthy, to manage society in an 
emergency." 8 This helped situate the social scientific intellectual inside the powers that were waging war. But it also fed a discursive distinction between realistic, rational or detailed concerns that could be understood with social science, on the one hand, and idealistic, emotional and desirous concerns that were not within the scope of a science equipped to understand international and cosmopolitan principles, on the other.

This was the trap, Randolph Bourne pointed out in his public sparring with Dewey in 1917, of allowing the state to implicitly direct what constituted legitimate/rational and illegitimate/irrational concerns. Bourne proposed that "the intellectuals whom the crisis has crystallized into an acceptance of war have put themselves into a terrifyingly strategic position, it is only on the craft, in the stream, they say, that one has any chance of controlling the current forces for liberal purposes." In other words, Bourne continued: "There seems no choice for the intellectual but to join the mass of acceptance."

But again the terrible dilemma arises-either support what is going on, in which case you count for nothing because you are swallowed in the mass, and great incalculable forces bear you on; or remain aloof, passively resistant, in which case you count for nothing because you are outside the machinery of reality.

Bourne understood the power that Rooseveltians, jingoes, hyper-nationalists and various other conservative forces could have through organizations such as the League to Enforce Peace. He was deeply sceptical of any calls for enforced internationalism, which he ridiculed as "a palpable apocalyptic

\footnotetext{
${ }^{8}$ Dewey, “A New Social Science," 292-94.
} 
myth." Wartime, he argued, had brought "the ideal of the State out into very clear relief", revealing "attitudes and tendencies that were hidden," unmasking an hysteria so intense, and a statist conservatism so strong, that intellectuals who hoped to distance themselves from the old nationalist guard while steering the nation towards a new internationalism were like "a child on a mad elephant's back": it was no more possible to control an enraged beast from atop than it was from the ground. " "The State," Bourne argued, was "all the autocratic, arbitrary, coercive, belligerent forces within a social group," a "complexus of everything most distasteful to the modern free creative spirit, the feeling for life, liberty, and the pursuit of happiness." The idea that one could work with the state in a time of war to push it towards a truly social, stateless internationalism was naïve. After all, Bourne famously argued, "War is the health of the State." 10

Bourne may have been rightly skeptical of those who hoped to steer the state beyond its own existence, particularly in a time of a war, where the identity of the nation state provided a central solidarity for conflicting parties. As the final chapter of this thesis showed, the loudest champions of a social scientific internationalism (those who imagined internationalism as a system beyond patriotic, emotional attachments to the nation-state) had their own

\footnotetext{
${ }^{9}$ Randolph Bourne, "War and the Intellectuals," ed. Carl Resek, War and the Intellectuals: Collected Essays, 1915-1918 (Indianapolis: Harper \& Row, 1964), 8-14. For more on the Dewey-Bourne debate see Robert Westbrook, "Pragmatism and Democracy: Reconstructing the Logic of John Dewey's Fiath," in The Revival of Pragmatism: New Essays on Social Thought, Law, and Culture, ed. Morris Dickstein, Copyright 1998. (Durham: Duke University Press Books, 1998), 128-140. ${ }^{10}$ Ibid.
} 
logic of reasonable versus emotive, and realistic versus idealistic, turned back on them. What Bourne's metaphor could not express, however, was the power of the ideal of a liberal stateless society alongside the power of 'the state itself. He believed it was possible to be in the state or stand fully clear of it to be either on top of the elephant or on the ground. His metaphor reconstituted an ideal of power as most problematic or worrisome when it was despotic, repressive and centralized in the state government. Such a view obscures the subtle effects of power at a more diffused and disciplinary level. ${ }^{11}$

Indeed, the story of the Inquiry's role in legitimating governance "outside" the state marks one instance, as Prozorov puts it elsewhere, of the realization that "it is the headless king that rules most effectively." 12 Working within the assumptions of the uniquely American conception of the liberal state, Bourne replicated the state effect that constructed a distinction between the state and society, such that even as he questioned the reality of the state, he lent legitimacy to a state-form ever more capable of governing. The distinction between despotic states and liberal societies, fuelled by Bourne and those Progressives who wrangled to enter the Inquiry, hinged the ideal of a new international not on state-to-state relations but on relations between liberated people unencumbered by centralized sovereign power. This same

\footnotetext{
${ }^{11}$ Graham Burchell, Colin Gordon, and Peter Miller, eds., The Foucault Effect: Studies in Governmentality, 1st ed. (Chicago: University Of Chicago Press, 1991), ix.

${ }^{12}$ S. Prozorov, "Three Theses on 'Governance' and the Political," Journal of International Relations and Development 7 (2004): 278. Emphasis added.
} 
distinction allowed the Inquiry, and most social scientists of their generation, to argue that even when they were working for the state, their knowledge was somehow not of it. Even Bourne's concept of a "trans-national" international assented to the ideal state mythologized by American political culture. ${ }^{13}$

Bourne's concerns highlight one of the assumptions that guided this thesis: that the international, like the state, is a space that has been modified throughout its brief history, but always with an eye to establishing a universal or common system of relations between people who are yet organized in smaller political sovereignties. The emerging social sciences, as I have shown here, provided the principal language for articulating this international with scientistic certainty in the generations before and during the First World War. But to conceptualize the international as a truly modern and scientifically knowable space, social scientists have had to present their conception of internationalism as an ontological break with older ways of ordering the world; they strengthened their conception by denying its dependence on specific, local contestations over power, yet they accomplished this, somewhat paradoxically, by elevating local (that is, national) political discourses to the level of delocalized global norms and standards.

The development of social science and the international must be understood, then, as relational, because of their shared and mutuallyinfluencing role in making the modern world comprehensible to observers.

\footnotetext{
${ }^{13}$ Randolph Bourne, "Trans-National America," Atlantic Monthly 118 (1916): 86-97.
} 
The relationship between internationalism and the development of social sciences has been particularly pronounced in the American scene explored here, because of that nation's mythos of its exceptional statelessness. I traced this relationship to just after the Civil War, when social scientists developed a concept of internationalism around the idea of states gradually converging, in juridical and legislative practices, around basic social principles largely inscribed by liberal political economy and common law. In keeping with the liberal political economy and historical view of the US as the inheritor of a Teutonic march of history, the concept of the international from this period placed the civic virtues and practices handed down to the US, which kept the nation and state apart, at the core of America's exceptional national identity. The latter was taken to be the basic grounds on which any viable and just international system would have to be formed.

As Chapter Two showed, early on there were variants of this civic conception of internationalism, most notably those jurists who imagined a progression toward a whole world bound by shared juridical practices. This was a rudimentary movement "beyond" the sovereign nation-state. Lawyers and other internationalists, including many American career diplomats and businessmen in this period, argued that international law provided the practical framework that could bind nations into a system formalized not at the level of the state, but at the level of common law, through juridical traditions and institutions arrived at by individual nations, formalized in state laws, but then shared across national boundaries to create systems that balanced state 
sovereignty with shared social interests. However, civic internationalism appears to have retreated to a more chauvinistic, statist and conservative form around the time of the Paris Commune. Facing the threat of an alternative international structure aligned along the axis of class, rather than romantic national identifiers such as virtue, civic internationalism became increasingly protective of the sovereign state's role in assuring the protection of liberal principles that could eventually spread.

Of course, the retreat to this more conservative civic internationalism was not accepted for long, and an alternative began to emerge in the 1880 s and 1890 s as the social sciences professionalized and disciplines fragmented into new constituent fields. American social scientists like the Washington Circle, who continued to imagine civic institutions as expressions of the nation and mediators between it and the state, looked to new social scientific fields to furnish them with scientistic knowledge that challenged the dogmas of laissez-faire political economy and a limited state. Here, I proposed, two distinct versions of liberal internationalism dovetailed in American thought. The first I have described as a reformed version of the early civic tradition, which imagined the liberal nation-state, mediated by a civic sphere, as the ultimate unit of international order. The other I have called social internationalism, and it imagined the state as both a reflection of constantly expanding and changing social solidarities and as an active agent in levelling inequality therein. 
The tension between these two ideals of internationalism, I argue, not only helped shape American exceptionalism in the Gilded Age and Progressive Era, but in so doing it also helped shape the boundaries of Āmerican social sciences. Social scientific knowledge complemented civic internationalism in the brief period after the war, as the authority to govern was passed from the church to a professional class made up of jurists, diplomats, men of letters and doctors, working in organizations like the ASSA and AIPSS. But as tensions over America's own social fabric grew and the interests of liberal capital seemed to take control of the mechanisms of the state, social scientists often used debates over the nature and purpose of internationalism to further their case for new ontologies and epistemologies that could explain and order the world. At first this took the form of the historico-political school with its accompanying ideas of arbitration, rather than codification, respecting American sovereignty while working to cultivate an international system around basic civil practices.

But the preponderance of the historico-political school and their ideal of arbitration was soon strained, this time by imperial expansion overseas. It was then that Theodore Roosevelt and a generation of like-minded social scientists, seizing on the language of Anglo-Saxonism and ideas around the necessity of a frontier in assuring the renewal of the American republic, proposed that the US was compelled by deeper social and cultural forces to join the international community of imperial nation-states in their efforts to civilize the world. Roosevelt's civilizational ideas of reform and progress 
reopened discussions about the nation-state as but one stage towards a more unified global system. This modified American exceptionalism, such that the American nation became the standard to which other nations ought to aspire. But at the same time Roosevelt's ideas also made America a player in an international scramble led by the state, compromising America's ability to differentiate its unique ideals of state and governance from what many saw as a European collection of imperial nations disposed to war by the petty rivalries of elites.

As Ian Tyrell has argued, and as I have shown here, the Great War shattered any sense that "the model of European imperial development" was "an alternative to purely national American themes."14 The election of Wilson and the crisis of the Great War created an opportunity for those who had long imagined an international system guided by scientific expertise and rigor. The thirst for a system of governance wholly unlike the reigning European balance-of-power, built as it was around imperialism and despotic states, created the space where what we now know as Wilsonianism would develop. Wilsonianism was partly a continuation of older rationalities about internationalism, particularly those which had already toyed with the ideal of a fully inclusive international system not restricted by race, civic cultures or class, but bound together by shared social and economic systems. Unlike its predecessors, however, Wilsonianism was more tightly wound around a faith

\footnotetext{
${ }^{14}$ Ian Tyrell, "Making Nations/Making States: American Historians in the Context of Empire," The Journal of American History 86 (1999): 1035.
} 
that America's exceptionalism was the product of an essentially stateless governmental system. The latter depended on knowledge developed in institutions and networks that were concerned with the management of society and the state, but not invested or influenced by them.

This mix was fertile ground for the social scientific experts who came of age in an era deeply concerned with explaining American national history as exceptional while the common problems of industrial capital appeared, on the contrary, to unify American and European history. These experts would support Wilson and help with the formation and running of the Inquiry. As their writings show, the social scientists attached to the peace process possessed an insurgent sense that the universalism of the scientific knowledge they generated about the social world provided the only viable way of clinging to the idea of American exceptionalism within a world that seemed increasingly interconnected and interdependent. The Inquiry has thus been understood here as an exemplary event in the relational development of the social sciences and internationalism, which highlights how local institutional battles took on a universalist tone in the struggle for governmental authority and, in so doing, helped create the conditions where attempts to sanctify a local liberal state form created the tools and rationalities of governmentality that would help shape our understanding, as well as the very practice, of internationalism. After marginalizing or culling out dissidents who challenged the perceived disinterestedness of the group, its members generated normative ideas about the nation-state's proper social attributes, 
fitting them to their own notion that the international system was best governed by a healthy system of non-state institutions, using social scientific methods and checking the division between the state and society through reform minded and liberal-conservative social science.

The impacts of the inquiry's organizing ideas, their methods, and the re-merging of social and civic internationalism under Wilsonianism, have been tremendous. They have also perhaps been underestimated by historians of the Inquiry, such as Lawrence Gelfand, and by historians of the Paris peace conference, such as Margaret MacMillan. The group's grounding assumption-that nation-states could be scientifically discerned, and were therefore static and historically essential-separated Inquiry members from the more epistemologically radical or critical thinkers of their generation, including some key figures purged or excluded from the Inquiry. The group pioneered the use of statistical and anthropological methods for organizing peoples into groups, making an unassailable and scientifically certain marriage between the nation and the state as the sine qua non of sovereignty and membership in the international system. Questions pertaining to the viability of collective security, or the mandate systems, or the future of global imperialism, were made irrelevant or ideological compared to the objective, methodical project of knowing a nation-state.

Although these ideas and methods would not go uncontested confronted as they were with older ideas of empire and militarism - the transcendence of the scientifically evident nation-state would eventually be 
taken for granted, laying the groundwork for theses such as the End of History, and legitimating the work of liberal internationalists in NGOs and international governing bodies. Grappling with the question of internationalism through social scientific rationalities has fostered a sense of cosmopolitanism and transnational potential among many in America's liberal reformer and intellectual elite - belief in the ideal of working towards collective security via the gentle guidance of pure, un-political, social scientific rationality. And yet, packaged as it is with scientism, social science also provided an exclusionary intellectual framework and language with which to understand internationalism, defining the limits of governmental possibility to reflect local-national power dynamics. It succeeded, to some degree, in cloaking the cultural and value judgments of an idiosyncratic American exceptionalism in the authority of a universal scientific grammar. The international has been and continues to be integral to framing national narratives, like the American one, not only to the ideological purpose of nation-making, but to the rationalization of globalization as a stateless and imminent process that seems to create borders for some while further dissolving them for select others. ${ }^{15}$

As early as the spring of 1918 , but especially with the preliminary release of the Versailles treaty in May 1919, the dream of an intellectual-led

\footnotetext{
${ }^{15}$ Louis A Pérez, "We Are the World: Internationalizing the National, Nationalizing the International," The Journal of American History 89 (2002): 558-566. Perez identifies this ideological influence in much of the new "international history," that has attempted to displace the nation state as the primary unit of historical narrative.
} 
international seemed to be slipping away for progressives who had once been integral to the philosophical underpinnings of Wilson's internationalism. Writing for The Nation, Hartley Alexander argued that militarism and nationalism had always threatened to break "the frail barriers of European diplomacy and the weak fortifications of international law." But just as they had leveled these old fortifications, they seemed now to threaten the new internationalisms promised by labor and the liberal intellectual.

If the spirit of the [labor] International was the least articulate, that of the intellectuals was the most articulate of the great professions of European culture. It is the very business of art and science and scholarship to express themselves, and to an international audience and for an international understanding; and there was no solidarity of Western civilization so pretentious as that of its intellectualism. When the leaders (for the intellectuals proclaimed themselves leaders) of all the great nations were masters and pupils to one another, how could there be-so it was imagined-a disruption of so bounded a unity? ... From the very first it was abundantly clear that the intellectualsnaturalists and historians and all-were merely propagandists of a narrow nationalism...the full significance of this collapse cannot be realized; but in the long run it will assuredly be found to be the most vital blow which the war has inflicted upon the modernism of the western world. ${ }^{16}$

Alexander had his finger not on a collapse of internationalism tout court,

but on the perverse power of a particular rationalization of internationalism that hinged on the ideal of a truly cosmopolitan, transnational governmental order apart from the nation-state, while simultaneously treating the nationstate as central to that order; he saw that all these groups ended up serving their tribal nation while veiling their intentions under the mask of

\footnotetext{
${ }^{16}$ Hartley B. Alexander, "The Failure Of The Intellectuals," The Nation 106 (1918): 563-564.
} 
cosmopolitanism. He witnessed, in this thesis's terms, the convergence of liberal exceptionalism and American exceptionalism.

The Inquiry embodied this movement through its modelling of governance around an ideal of a stateless internationalism, which in turn multiplied the potential sites of legitimate governmental authority and, by extension, the possibilities of social science as the core of internationalism. But by definition, the social sciences also restricted the limits of acceptable discourse on international governance. The idea of cosmopolitan expertise, which had been refined over the course of the late nineteenth and early twentieth centuries, culminated in an explosion of expert commissions scientific governance bodies connected to that formal political international organization par excellence, the League of Nations. The same idea also opened up a space for international civilian-expert groups, which carried forward the causes of sanitation, charity, food, economic management, children's rights, anti-prostitution, and international peace (once the purview of a small group of social reformers advocating the application of scientific method) to managing the problems of an increasingly interdependent modern world. ${ }^{17}$

\footnotetext{
${ }^{17}$ The Inquriy was not the only early expression of expert mediation that grew out of the War. The Women's Peace Party and the Women's International League for Peace and Freedom, which called for "Continuous Mediation" that Jane Addams imagined manifesting itself as "An international commission of experts ... with scientific but no diplomatic function" Cited in Marie Louise Degen, The History of The Women's Peace Party (New York: Garland Publishing, 1972), 46. This transnational network of experts called for a scientific management to peace but, unlike the Inquiry and its antecedents that were more overtly preoccupied with cooperating with the power of state apparatuses, its internationalism was not
} 
It follows that the relational development of social science and internationalism also provided fertile ground for the emergence of the modern think-tank. This is not to say that think tanks as we recognize them are the inevitable outcome of the Inquiry moment, but that the convergence of particular discourses and rationalities about internationalism, governance and social science facilitated the development of the think tank and shape how such institutions are thought of vis-a-vis government and the state. Directly concerned with governance, yet convinced of their place in a civic sphereas evidenced by their employment of academics instead of or alongside politicians and business reformers-think tanks became, at some point, a legitimate source of governmental knowledge. In the case of think tanks concerned with international governance, this status is made possible, at least in part, by the co-constituting of internationalism and social science in liberal states. Even the ability of domestic think tanks to claim the space both inside and outside "the system" depends on a concept of the international that privileges the state-society divide, and the nation-state as its core component. ${ }^{18}$

anchored to the buried nationalism and faith in American statelessness that largely defined the Inquiry social scientists.

${ }^{18}$ There is, in fact, a more immediate line between the Inquiry and the emergence of the modern think tank. The personnel who filled the Council on Foreign Relations when it was formed in 1921 were drawn largely drawn from the Inquiry. Likewise, Britain's Chatham House, established in 1920, was built by veterans of the Paris Peace Conference, including its first chair, Robert Cecil, who had been an advocate of a League of Nations and a close colleague with those Inquiry members who also traveled to Paris. But, to avoid falling victim to a Whiggish interpretation of their emergence as a natural adaptation to the changing world, the connection between the think tank and the Inquiry must be understood as the result of protracted and historically specific struggles to define the state and society during a period of increasingly global 
Be it through ethnographic, economic, historical geographical, sociological or simply statistical data, the hierarchy of knowledge that allows modern non-state governmental organs to guard the perception of even semiindependence from a state or political system, while being deeply preoccupied with state conduct and bound to local conditions, is always in part the product of micro-sociological power struggles over methods, ontological assumptions and heuristic devices. The story of the relational development of social science, culminating (for our purposes) in the story of the Inquiry, offers a glance at the malleability of governmental rationalities at the base of internationalism and points to the importance of understanding them. The point is not to elevate The Inquiry and its "scientific men" to any omnipotent or determining status, but to refuse to take them, and their particular combination of social science and internationalism, for granted. world that were relevant to a generation struggling with the social upheavals of industrial society. 


\section{Bibliography}

\section{Archival Collections Consulted}

Columbia University, Rare Book and Manuscript Library

John Bates Clark

James T. Shotwell

Sidney Mezes

William L. Westermann

Cornell University, Division of Rare and Manuscript Collections

Andrew Dickson White

George Lincoln Burr

Harvard University, Pusey and Houghton Libraries

Archibald Cary Coolidge

Caroline Healey Dall

Charles Eliot Norton

Charles William Eliot

Roland B. Dixon

Walter Hines Page

Johns Hopkins University, Special Collections

Daniel Coit Gilman

Herbert Baxter Adams

Isaiah Bowman Papers

University of Chicago, Special Collections

Course Calendars

Frederick Starr Papers

William Rainey Harper

W.I. Thomas Archival Biographical File

U.S. National Archives, College Park, Maryland

Records of the American Commission to Negotiate Peace, 1918-1931, RG 256.3

Records of the Inquiry, 1914-1919, RG 256.2

Library of Congress, Washington D.C., Manuscripts Reading Room

American Historical Association

National Board for Historical Services

William E. Dodd

James McKeen Cattell

John Franklin Jameson 
Yale University, Manuscripts and Archives

American Social Science Association

Clive Day

Charles Homer Haskins

Charles Seymour

Edward Mandell House Diary

George Burton Adams

Gordon Auchincloss

The Inquiry Papers

Walter Lippmann

William Bullitt

William Graham Sumner

\section{Academic Journals}

American Journal of Sociology

British Journal of Social Science

History Teacher Magazine

Journal of Social Science

North American Review

Political Science Quarterly

Publications of the American Statistical Association

Science

The American Historical Review

The Annals of the American Academy of Political and Social Science

The Quarterly Journal of Economics

News Papers, Periodicals

American Archivist

Education: A Monthly Magazine

Independent

Leavenworth Echo

New York Evening Post

New York Evening Standard

New York Times

New York Tribune

Philadelphia Public Ledger

Scribner's Magazine

The Dial

The Forum Magazine

The Literary Digest

The Living Age

The Nation

The New Republic

The North American Review 
The Times

Washington Post

\section{Contemporary Reports, Pamphlets, Special Publications and Books}

Adams, Henry Carter. Outline of Lectures Upon Political Economy: Prepared for the use of Students at the University of Michigan and Cornell University. Ann Arbor: Register Publishing House, 1886.

Adams, Herbert B. Methods of Historical Study, The Johns Hopkins University Studies in History and Political Science. Baltimore: Freeman, 1884.

American Historical Association Conference Papers Saratoga, 9-10 September 1884

Beer, George Louis. The English Speaking People: Their Future Relations and Joint International Obligations. New York: Macmillan Press, 1917.

Bellamy, Edward. Equality [1898]. New York: Cosimo, Inc., 2008.

- Looking Backward. New York: Applewood Books, 2000.

Bourne, Randolph. "Trans-National America." Atlantic Monthly 118 (1916): 8697.

- "The State" [1918]. In War and the Intellectuals, edited by Carl Resek. New York: Harper \& Row, 1964.

Bowman, Isaiah. The New World: Problems in Political Geography. New York: World Book, 1928.

Boydston, Jo Ann (ed.) The Collected Works of John Dewey, 1882-1953. Carbondale, IL: Southern Illinois University Press, 1969-1991.

Burgess, John William. Political Science and Comparative Constitutional Law, Volume One. Boston: Ginn \& Company, 1890.

Coolidge, Archibald Cary. The United States as a World Power. New York: The Macmillan Company, 1908.

Croly, Herbert David. The Promise of American Life. New York: Macmillan, 1911.

Ely, Richard T. French and German Socialism in Modern Times. New York: Harper, 1883. 
- Problems of Today: A Discussion of Protective Tariffs, Taxation, and Monopolies. New York: T. Y. Crowell, 1888.

- Recent American Socialism. In Studies in Historical and Political Science, edited by Herbert Baxter Adams. Baltimore: Johns Hopkins University, 1888.

Field, David Dudley. An International Code: Address on the Subject Before the Social Science Association at Manchester, 5 October 1866. New York: W.M. Read, Book and Job Printer, 1867.

Giddings, Franklin H. Democracy and Empire: With Studies of Their Psychological, Economic, and Moral Foundations. New York: The Macmillan company, 1900.

Gilman, Daniel Coit and Andrew Dickson White. "Report on the Cartographical Evidence of the Geographers." Box 74, Andrew Dickson White Papers, \#01-02-02, Division of Rare and Manuscript Collections, Cornell University Library.

Gilman, Daniel Coit. Bluntschli, Lieber and Laboulaye. Baltimore: Privately printed for a few friends in Baltimore, 1884.

- James Monroe $\square$ : with a Bibliography of Writings Pertinent to the Monroe Doctrine by John F. Jameson. Boston: Houghton, 1898.

Haskins, Charles. Some Problems of the Peace Conference. Cambridge, MA: Harvard University Press, 1922.

Journal of Social Science: containing the Proceedings of the American Association, (1872)

Keynes, John Maynard. The Economic Consequences of the Peace [1919]. New York: Skyhorse Publishing, 2007.

Lansing, Robert. The Peace Negotiations: A Personal Narrative. Boston: Houghton Mifflin, 1921.

Lieber, Francis. On civil liberty and self-government. New York: Richard Bentley, 1853.

- The Miscellaneous Writings of Francis Lieber: Contributions to Political Science, Including Lectures on the Constitution of the United States, and Other Papers. New York: J.B. Lippincott, 1881. 
Link, Arthur et al. (eds.) The Papers of Woodrow Wilson (PWW), 69 vols. Princeton: Princeton University Press, 1966-1994.

Lippmann, Walter. The Political Scene: An Essay on the Victory of 1918. New York: Holt, 1919.

de Martonne, Emmanuelle. Proceedings of the Study Committee, Alsace-

Lorraine and the Border of North-East. Paris: Imprimerie Nationale, 1919.

Miller, David Hunter. The Drafting of the Covenant (2 vols.). New York:

Putnam's Sons Co., 1923.

Publications of the American Economic Association

Robinson, James Harvey . The Mind in the Making: The Relation of Intelligence to Social Reform. London: Jonathan Cape, 1921.

. The Humanizing of Knowledge. New York: Arno Press, 1923.

- The New History. New York: Macmillan Press, 1912.

Root, Elihu and George B. Davis. "Francis Lieber." In Proceedings of the American Society of International Law at Its Annual Meeting, 1907-1917 7, 1913.

Root, Elihu. "Roosevelt's Conduct of Foreign Affairs." In The Works of Theodore Roosevelt, edited by Hermann Hagedorn. New York, 1925.

Ross, E.A. Sin and Society. New York: Houghton Mifflin, 1907.

What is America? New York: Century Co., 1919.

Rothberg, Morey (ed.) Selected Essays of John Franklin Jameson. Athens, GA: University of Georgia Press, 1993.

Scruggs, William Lindsay. British Aggressions in Venezuela: Or, The Monroe Doctrine on Trial. New York: The Franklin printing and publishing co., 1895.

Seymour, Charles. Geography, Justice, and Politics at the Paris Conference of 1919. New York: The American Geographical Society, 1951.

- The Intimate Papers of Colonel House. New York: Houghton Mifflin, 1928. 
Shotwell, James T. At the Paris Peace Conference. New York: Scribner and Sons, 1937.

- At the Paris Peace Conference. New York: Scribner and Sons, 1937.

-Intelligence and Politics. New York: Century Co., 1921.

—. Long Way to Freedom. Indianapolis: Bobbs Merrill, 1960.

- The Reminiscences of James T. Shotwell (1964). The Oral History Collection of Columbia University.

Thomas, W.I. The Child in America: Behavior Problems and Programs. New York: Alfred A. Knopf, 1928.

Transactions of the National Association for the Promotion of Social Science 1862-1869

Turner, Frederick J. The Frontier in American History [1893], New York: F. Ungar Pub. Co, 1966.

- "The Significance of History" [1890]. In Early Writings of Frederick Jackson Turner. Madison: University of Wisconsin Press, 1938.

Veblen, Thorstein. "Suggestions Touching the Working Program of an Inquiry Into the Prospective Terms of Peace." In Joseph Dorfman, "Veblen on the Nature of Peace," Political Science Quarterly 47 (1932): 185-203.

—. The Nature of Peace. New York: Transaction Publishers, 1917.

Ward, Lester Frank. Dynamic Sociology, or Applied Social Science: As Based Upon Statical Sociology and the Less Complex Sciences, V.1 [1883]. Ithaca: Cornell University Press, 2009.

- The psychic factors of civilization. New York: Ginn \& Company, 1892.

White, Andrew Dickson. Autobiography of Andrew Dickson White. Cambridge: Harvard University Press, 1905.

Wilson, Woodrow. The State: Elements of Historical and Practical Politics. Boston: D.C. Heath, 1898.

Woolsey, Theodore Dwight. Political science: Or, The State Theoretically and Practically Considered. New York: Scribner, Armstrong \& company, 1877. 


\section{Secondary Sources: Articles, Books, Dissertations}

Abbott, Andrew. The System of Professions: An Essay on the Division of Expert Labor. Chicago: University of Chicago Press, 1988.

Abbott, Andrew. Time Matters. Chicago, University of Chicago Press, 2001.

Abrams, Irwin. "The Emergence of the International Law Societies." The Review of Politics 19 (1957): 361-380.

Adams, Bluford. "World Conquerors or a Dying People? Racial Theory, Regional Anxiety, and the Brahmin Anglo-Saxonists." The Journal of the Gilded Age and Progressive Era 8 (2009): 189-215.

Adams, David Keith and Cornelis A. van Minnen. Reflections on American Exceptionalism. Edinburgh: Edinburgh University Press, 1994.

Adler, Emannuel and Peter M. Haas. "Conclusion: Epistemic Communities and International Policy Coordination," International Organization 46 (1992): 361-390.

Ambrosius, Lloyd E. Wilsonianism: Woodrow Wilson and His Legacy in American Foreign Relations. New York: Palgrave Macmillan, 2002.

Ambrosius, Hoyd E. Woodrow Wilson and the American Diplomatic Tradition: The Treaty Fight in Perspective (New York: Cambridge University Press, 1990.

Andelson, Robert V. and Gaffney, Mason. "Seligman and His Critique from Social Utility." American Journal of Economics and Sociology 62 (2003): 407-432.

Anderson, Perry. "Internationalism: A Breviary." New Left Review 14 (2002): 614.

Anderson, Stuart. Race and Rapprochement: Anglo-Saxonism and AngloAmerican Relations, 1895-1904. Rutherford, N.J.: Fairleigh Dickinson University, 1981.

Armstrong, Hamilton Fish. Peace and Counterpeace: From Wilson to Hitler. New York: Harper and Row Publishers, 1922.

Armstrong, William M. E.L. Godkin: A Biography. New York: SUNY Press, 1978. 
Barrow, Clyde W. More than a Historian: The Political and Economic Thought of Charles A. Beard. New York: Transaction Publishers, 2000.

Bender, Thomas. A Nation Among Nations: Americas Place in World History. New York: Hill \& Wang, 2006.

Bender, Thomas. Intellect and Public Life: Essays on the Social History of Academic Intellectuals in the United States. The Johns Hopkins University Press, 1997.

Bergquist, Harold E. "The Edward W. Bemis Controversy at the University of Chicago." AAUP Bulletin 58 (1972): 384-393.

Bernstein, Samuel. "The Impact of the Paris Commune in the United States," The Massachusetts Review 12 (1971): 435-446.

Blitch, Charles P. "Allyn A. Young: A Curious Case of Professional Neglect." History of Political Economy 15 (1983): 1-24.

Boulineau, Emmannuelle. « Un geographe traceur de frontières: Emmanuel de Martonne et la Roumanie. » L'Espace Geographique 4 (2001): 358-369.

Bourne, Randolph. "The State" [1918]. In War and the Intellectuals, edited by Carl Resek. New York: Harper \& Row, 1964.

Breisach, Ernst. American Progressive History: An Experiment in Modernization. Chicago: University of Chicago Press, 1993.

Bright, Charles and Michael Geyer. "Where in the World is America? The History of the United States in the Global age." In Rethinking American history in a Global Age, edited by Thomas Bender, 63-100. Berkeley: University of California Press, 2002.

Brundage, Anthony and Richard Cosgrove. The Great Tradition: Constitutional History and National Identity in Britain and the United States, 1870-1960. Stanford: Stanford University Press, 2007.

Burchell, Graham, Colin Gordon, and Peter Miller (eds.). The Foucault Effect: Studies in Governmentality, lst ed. Chicago: University Of Chicago Press, 1991.

Calhoun, Craig. "Sociology in America: An Introduction." In Sociology in America: $\bar{A}$ History, edited by Calhoun, Craig. Chicago: University of Chicago Press, 2007. 
Caudill, Edward. "E. L. Godkin and the Science of Society." Journalism Quarterly 66 (1989): 57-64.

Chace, James. 1912: Wilson, Roosevelt, Taft and Debs -The Election That Changed the Country. Toronto: Simon \& Schuster, 2004.

Chernev, Borislav. "The Brest-Litovsk Moment: Self-Determination Discourse in Eastern Europe Before Wilsonianism." Diplomacy \& Statecraft 22 (2011): 369-387.

Clinton, David. "Francis Lieber, Imperialism, and Internationalism." In Imperialism and Internationalism in the Discipline of International Relations, edited by Long, David and Brian C. Schmidt New York: SUNY Press, 2005.

Cohen, Nancy. The Reconstruction of American Liberalism, 1865-1914. Chapel Hill: University of North Carolina Press.

Contee, Clarence G. "Du Bois, the NAACP, and the Pan-African Congress of 1919." The Journal of Negro History 57 (1972): 13-28.

Cooper, John Milton, Jr., Breaking the Heart of the World: Woodrow WIlson and the Fight for the League of Nations (New York: Cambridge University Press, 2001.

- The Warrior and the Priest: Woodrow Wilson and Theodore Roosevelt Cambridge, Mass: Belknap Press, 1985.

. Woodrow Wilson: A Biography. Random House Digital, Inc., 2011.

Crampton, Jeremy. "The Cartographic Calculation of Space: Race Mapping and the Balkans at the Paris Peace Conference of 1919." Social and Cultural Geography 7 (2006): 731-752.

Crapol, Edward P. "Coming to Terms with Empire: The Historiography of Late Nineteenth Century American Foreign Relations." Diplomatic History 16, no. 4 (October 1, 1992): 573-598.

Crook, David Paul. Darwinism, War, and History: The Debate Over the Biology of War from the "Origin of Species" to the First World War. New York: Cambridge University Press, 1994.

Curry, George. "Woodrow Wilson, Jan Smuts, and the Versailles Settlement," American Historical Review 66 (1961): 968-986. 
Curtis, Bruce. "After 'Canada': Liberalism, Social Theory and Historical Analysis." In Liberalism and Hegemony: Debating the Canadian Liberal Revolution, edited by Jean-Francois Constant and Michel Ducharme, lst ed, 176-200. Toronto: University of Toronto Press, Scholarly Publishing Division, 2009.

- "Foucault on Governmentality and Population: The Impossible Discovery." The Canadian Journal of Sociology / Cahiers Canadiens De Sociologie 27 (2002): 505-533.

Dafoe, J. W. "Canada and the Peace Conference of 1919." Canadian Historical Review 24 (1943): 233-248.

Davidson, John W. "Wilson in the Campaign of 1912,", ed. Earl Latham, The Philosophy and Policies of Woodrow Wilson. Chicago: University of Chicago Press, 1958.

Davis, David Brion. The Problem of Slavery in the Age of Revolution, 1770-1823. New York: Oxford University Press, 1999.

Dawley, Alan. Changing the World: American Progressives in War and Revolution. Princeton: Princeton University Press, 2003.

Dean, Mitchell M. Governmentality: Power and Rule in Modern Society. Thousand Oaks: Sage Publications Ltd, 2009.

Dean, Mitchell M. Governing Societies. New York: Open University Press, 2007.

Deegan, Mary Jo. Jane Addams and the Men of the Chicago School, 1892-1918. New York: Transaction Publishers, 1990.

-. "A Very Different Vision of Jane Addams and Emily Greene Balch: A comment on 'Nobel Peace Laureates, Jane Addams and Emily Greene Balch."' The Journal of Women's History 7 (1995): 6-26.

Degen, Marie Louise. The History of The Women's Peace Party. New York: Garland Publishing, 1972.

Deleuze, Gilles. Foucault, translated by Sean Hand. New York: Continumm Press, 2006.

Delpar, Helen. Looking South: The Evolution of Latin Americanist Scholarship in the United States, 1850-1975. Tuscaloosa: University of Alabama Press, 2007. 
DeSantis, Hugh "The Imperialist Impulse and American Innocence, 18651900." In American Foreign Relations, A Historiographical Review, edited by Gerald Haines and Samuel J. Walker, 65-90. Westport, CT: Greenwood Publishing, 1981.

Dewey, John. "Essays on China, Japan, and the War." In The Middle Works of John Dewey, Volume 11, 1899 - 1924, edited by Jo Ann Boydston. Carbondale: Southern Illinois University Press, 1988.

Diggins, John P. Thorstein Veblen: Theorist of the Leisure Class. Princeton University Press, 1999.

Doenecke, Justus D. Nothing Less Than War. Lexington: University of Kentucky Press, 2011.

Dorfman, Joseph. The Economic Mind in America, Vol. 3. New York: A. Kelley Publishing, 1969.

Dyer, Thomas G. Theodore Roosevelt and the Idea of Race. Baton Rouge: Louisiana State University Press, 1992.

Edwards, Stewart. The Paris Commune 1871. London: Eyre and Spottiswoode, 1971.

Eggert, Gerald G. Richard Olney: Evolution of a Statesman. University Park: Pennsylvania State University Press, 1974.

Eulau, Heinz. "Wilsonian Idealist: Walter Lippmann Goes to War." The Antioch Review 14 (1954): 81-108.

Eyffinger, Arthur. The 1899 Hague Peace Conference: "The Parliament of Man, the Federation of the World." The Hague: Martinus Nijhoff Publishers, 1999.

Farr, James. "Political Science and the State," in Discipline and History: Political Science in the United States. Ann Arbour: University of Michigan Press, 1993.

Farr, James. "The Historical Science(s) of Politics: The Principles, Association, and Fate of an American Discipline," in Modern Political Science: AngloAmerican Exchanges Since 1880, edited by Robert Adcock et al., 66-96. Princeton, N.J.: Princeton University Press, 2007. 
Feuer, Lewis S. "Horace M. Kallen on War and Peace." In The Legacy of Horace $M$ Kallen, edited by Milton R. Konvitz. Mississauga, Ontario: Associated University Press, 1987.

Field, James A. "American Imperialism: The Worst Chapter in Almost Any Book." The American Historical Review 83 (1978): 644-668.

Fleming, Denna Frank. The United States and the League of Nations, 1918-1920. New York: G.P. Putnam, 1932.

Foner, Eric. Reconstruction: America's Unfinished Revolution, 1863-1877. New York: Harper Perennial Modern Classics, 2002.

Forcey, Charles. The Crossroads of Liberalism: Croly, Weyl, Lippmann and the Progressive Era, 1900-1925. New York: Oxford university Press, 1961.

Forman, Michael. Nationalism and the International Labor Movement: The idea of the nation in socialist and anarchist theory. University Park, Penn.: Pennsylvania State Press, 1998.

Foucault, Michel. "Truth and Power." In Power/Knowledge: Selected Interviews and Other Writings, 1972-1977, edited by Colin Gordon. New York: Pantheon Books, 1980.

Foucault, Michel and Gilles Deleuze. "Intellectuals and Power: A Conversation Between Michel Foucault and Gilles Deleuze." In Language, CounterMemory, Practice, edited by Donald F. Bouchard, 165-197. Ithaca: Cornell University Press, 1977.

Freud, Sigmund and Bullitt, William Christian. Woodrow Wilson: $A$ Psychological Study. New York: Houghton Mifflin Co., 1967.

Fry, Joseph A. "From Open Door to World Systems: Economic Interpretations of Late Nineteenth Century American Foreign Relations." Pacific Historical Review 65 (1996): 277-303.

Furner, Mary O. Advocacy and Objectivity: A Crisis in the Professionalization of American Social Science, 1865-1905.

Gabay, Nadav. "The Political Origins of Social Science: British Parliament and the Emergence of Scientific Policy Making, 1803-1857," Ph.D. diss., University of California San Diego, 2007.

Gargan, Edward T. "The American Conservative Response." International Review of Social History 17 (1972): 240-249. 
Gelfand, Lawrence. The Inquiry: American Preperations for Peace, 1917-1919. New Haven: Yale University Press, 1963.

- "Review of Le Role Des Experts a La Conference De La Paix De 1919: Gestation D'une Technocratie En Politique Internationale by Dimitri Kitsikis." Journal of Modern History 45 (1973): 697-699.

Gerson, Louis. Woodrow Wilson and the Rebirth of Poland. New Haven: Yale University Press, 1953.

Gerstle, Gary. "Theodore Roosevelt and the Divided Character of American Nationalism," The Journal of American History 86 (1999): 1280-1307.

- "The Protean Character of American Liberalism," The American Historical Review 99 (1994): 1043-1073.

Gluckstein, Donny. The Paris Commune: A Revolution in Democracy. Chicago: Haymarket Books, 2011.

Go, Julian. 'The Provinciality of American Empire: 'Liberal Exceptionalism' and U.S. Colonial Rule, 1898 -1912." Comparative Studies in Society and History 49 (2007): 74-108.

Goldman, Lawrence. "Exceptionalism and Internationalism: The Origins of American Social Science Reconsidered." Journal of Historical Sociology 11 (1998): 1-36.

- "The Social Science Association, 1857-1886: A Context for MidVictorian Liberalism." The English Historical Review 398 (1986): 95-134.

- Science, reform, and Politics in Victorian Britain: The Social Science Association, 1857-1886. New York: Cambridge University Press, 2002.

Goldmann, Kjell. The Logic of Internationalism: Coercion and Accommodation. New York: Routledge, 1994.

Gräser, Marcus. "World History in a Nation-State: The Transnational Disposition in Historical Writing in the United States." The Journal of American History 95 (2009): 1038-1052.

Grose, Peter. Continuing the Inquiry: The Council on Foreign Relations from 1921 to 1996. New York: Council on Foreign Relations Press. 
Gross, Neil. "Pragmatism, Phenomenology, and Twentieth Century American Sociology." In Sociology in America: A History, edited by Calhoun, Craig. Chicago: University of Chicago Press, 2007.

Gruber, Carol S. Mars and Minerva: World War I and the Uses of the Higher Learning in America. Louisiana State University Press, 1975.

Gunnell, John G. "In Search of the State: Political Science as an Emerging Discipline in the U.S." In Discourses on Society: the Shaping of the Social Science Disciplines, edited by Peter Wagner, Björn Wittrock, and Richard Whitley, 123-162. Norwell, MA: Kluwer Publishers, 1991.

- "The Real Revolution in Political Science." PS: Political Science \& Politics 37 (2004): 47-50.

- The Descent of Political Theory: The Genealogy of an American Vocation. Chicago: University of Chicago Press, 1993.

Gunther, Gerald. Learned Hand: The Man and the Judge. New York: Knopf, 1994.

Guyatt, Nicholas. "America's Conservatory: Race, Reconstruction, and the Santo Domingo Debate." Journal of American History 97 (2011): 974 1000.

Haas, Peter M. "Introduction: Epistemic Communities and International Policy Coordination." International Organization 46 (1992): 1-35.

Hannah, Matthew G. Governmentality and the Mastery of Territory in Nineteenth-Century America. New York: Cambridge University Press, 2000.

Harbaugh, William H. ed. The Writings of Theodore Roosevelt (Indianapolis: Bobbs-Merill, 1967.

Hardt, Michael and Negri, Antonio. Empire. Cambridge: Harvard University Press, 2001.

Harold Josephson, James T. Shotwell and the Rise of Internationalism in America. Cranbury, N.J.: Associated University Presses, 1975.

Haskell, Thomas L. The Emergence of Professional Social Science: The American Social Science Association and the Nineteenth-Century Crisis of Authority. Baltimore: Johns Hopkins University Press, 2000. 
Haslam, Jonathan. The Vices of Integrity: E.H. Carr 1892-1982. New York: Verso Pres, 1999.

Hay, Colin. "Political Ontology." In The Oxford Handbook of Contextual Political Analysis, edited by Robert E. Goodin and Charles Tilly, 76-96. New York: Oxford University Press, 2006.

Hedges, Chris. Death of the Liberal Class. New York: Nation Books, 2010.

Heffernan, M. "Geography, Cartography and Military Intelligence: The Royal Geographical Society and the First World War." Transactions of the Institute of British Geographers 21 (1996): 504-533.

Heilbron, Johan and Guilhot, Nicolas and Jeanpierre, Laurent. "Toward a Transnational History of the Social Sciences." Journal of the History of the Behavioral Sciences 44 (2008): 146-160.

Heilbron, Johan. "The Rise of the Social Sciences in France." European Journal of Social Sciences 42 (2004): 145-157.

Herzberg, David L. "Thinking Through War: The Social Thought of Richard T. Ely, John R. Commons and Edward A. Ross During the First World War." Journal of the History of the Behavioral Sciences 37 (2001).

Heyman, Richard. "Libraries as Armouries: Daniel Coit Gilman, geography, and the uses of a university." Environment and Planning D: Society and Space 19 (2001): 295-316.

Hindess, Barry. "Liberalism-What's In a Name?" In Global Governmentality: Governing International Spaces, edited by Wendy Larner and William Walters. New York: Routledge Press, 2004.

Hinsley, Francis Harry. Power and the Pursuit of Peace: Theory and Practice in the History of Relations Between States. New York: Cambridge University Press, 1967.

Hobsbawm, Eric. Nations and Nationalism since 1780: Programme, Myth, Reality. Cambridge: Cambridge University Press, 1992.

Hodgson, Godfrey. Woodrow Wilson's Right Hand: The Life of Colonel Edward M. House. New Haven: Yale University Press, 2006.

Hoffman, Stanley. "The Crisis of Liberal Internationalism," Foreign Policy 98 (1995): 159-177. 
Hofstadter, Richard and Metzger, Walter P. The Development of Academic Freedom in the United States. New York: Columbia University Press, 1955.

Hofstadter, Richard. Anti-Intellectualism in American Life. New York: Alfred A. Knopf, 1967.

Hoganson, Kristin L. Fighting for American Manhood: How Gender Politics Provoked the Spanish-American and Philippine-American Wars. New Haven: Yale University Press, 2000.

Holbraad, Carsten. Internationalism and Nationalism in European Political Thought, 1st ed. New York: Palgrave Macmillan, 2003.

Hollinger, David A. "Science and Anarchy: Walter Lippmann's Drift and Mastery." American Quarterly 29 (1977): 463-475.

Horne, Alistair. The Terrible Year: The Paris Commune, 1871. Phoenix: Orion Publishing, 2004.

Horsman, Reginald. Race and Manifest Destiny: The Origins of American Racial Anglo-Saxonism. Cambridge: Harvard University Press, 1981.

Hutchinson, William T. "The American Historian in Wartime" The Mississippi Valley Historical Review 29, (1942): 163-186.

Iriye, Akira. Global Community: The Role of International Organizations in the Making of the Contemporary World, lst ed. Berkeley: University of California Press, 2004.

Jacobini, H. B. "Some Observations Concerning Jeremy Bentham's Concepts of International Law." The American Journal of International Law 42 (1948): 415-417.

Jacobson, Matthew Frye. Barbarian Virtues: The United States Encounters Foreign Peoples at Home and Abroad, 1876-1917. New York: Hill and Wang, 2001.

James, William. "Pragmatism." In Pragmatism and Other Writings, edited by Giles Gunn. New York: Penguin Classics, 2000.

Johnson, Donald. "Wilson, Burleson, and Censorship in the First World War." The Journal of Southern History 28 (1962): 46-58. 
Johnston, Robert D. The Radical Middle Class: Populist Democracy and the Question of Capitalism in Progressive-Era Portland, Oregon. Princeton: Princeton University Press, 2003.

Joseph, Jonathan. "The Limits of Governmentality: Social Theory and the International." European Journal of International Relations 16 (2010): 223246.

Kaplan, Sydney. "Social Engineers as Saviors: Effects of World War I on some American Liberals." Journal of History of Ideas 17 (1956): 347-348.

Katz, Philip Mark. From Appomattox to Montmartre: Americans and the Paris Commune. Cambridge: Harvard University Press, 1998.

Kazin, Michael. The Populist Persuasion. Ithaca: Cornell University Press, 1998.

Keller, Morton. Ed. Problems of Modern Democracy: Political and Economic Essays. Cambridge: Harvard University Press, 1966.

Kennan, George Frost. American Diplomacy, 1900-1950. New York: New American Library, 1951.

Kennedy, David M. Over Here: The First World War and American Society. New York: Oxford University Press, 2004.

Kloppenberg, James T. Uncertain Victory: Social Democracy and Progressivism in European and American Thought, 1870-1920. New York: Oxford University Press, 1986.

Kloppenberg, James T. "Nancy Cohen. The Reconstruction of American Liberalism, 1865-1914." The American Historical Review 108 (2003): 843844.

Knock, Thomas J. To End All Wars: Woodrow Wilson and the Quest for a New World Order. Princeton University Press, 1995.

Kolko, Gabriel. The Triumph of Conservatism: A Reinterpretation of American History, 1900-1916. New York: The Free Press, 1963

Koskenniemi, Martti The Gentle Civilizer of Nations: The Rise and Fall of International Law 1870-1960. New York: Cambridge University Press, 2004. 
Kramer, Paul A. "Empires, Exceptions and Anglo-Saxons: Race and Rule between the British and United States Empires, 1880-1920." Journal of American History 88 (2002): 1315-1353.

Lacey, Michael J. and Furner, Mary O. The State and Social Investigation in Britain and the United States New York: Cambridge University Press, 2004.

Lacey, Michael J. "The World of Bureaus: Government and the Positivist Project in the Late Nineteenth Century," in The State and Social Investigation in Britain and the United States, edited by Mary O. Furner and Michael J. Lacey. New York: Cambridge University Press, 2004.

LaFeber, Walter. The New Empire: An Interpretation of American Expansion, 1860-1898. Ithaca: Cornell University Press, 1998.

Larner, Wendy and Walters. William Global Governmentality: Governing International Spaces. New York: Psychology Press, 2004.

Lasch, Christopher. "The Anti-Imperialists, the Philippines, and the Inequality of Man." The Journal of Southern History 24 (1958): 319-331.

- The New Radicalism in America, 1889-1963: The Intellectual As Social Type. New York: Alfred A. Knopf, 1965.

Lears, T. J. Jackson. No Place of Grace: Antimodernism and the Transformation of American Culture, 1880-1920. Chicago: University of Chicago Press, 1981 .

Lemke, Thomas. "An Indigestible Meal? Foucault, Governmentality and State Theory." Distinktion: Scandinavian Journal of Social Theory 8 (2007): 4364.

Lewis Paul Todd, "Wartime Relations of the Federal Government and the Public Schools, 1917-1918," American Education: Its Men, Ideas and Institutions, (New York: Arno Press, 1971.

Lippmann, Walter. Drift and Mastery. Englewood Heights, N.J.: Prentice Hall, 1961.

Lippmann, Walter. The Stakes of Diplomacy. New York: H. Holt, 1915.

Lipset, Seymour Martin. The First New Nation: The United States in Historical and Comparative Perspective. New York: Transaction Publishers, 2003. 
Livingston, James. Pragmatism and the Political Economy of Cultural Revolution, 1850-1940. Chapel Hill: The University of North Carolina Press, 1997.

---. Pragmatism, Feminism, and Democracy: Rethinking the Politics of American History. New York: Routledge, 2001.

Livingstone, David N. Darwin's Forgotten Defenders: The Encounter between Evangelical Theology and Evolutionary Thought. Edinburgh: Scottish Academic Press, 1987.

Louis, Roger. "The United States and the African Peace Settlement of 1919: The Pilgrimage of George Louis Beer," The Journal of African History 2 (1963): 413-433.

Lowczyk, Olivier. «Définir La Carte De l'Europe Après La Première Guerre Mondiale, Le Rôle Du Comité D'études.» Ph.D. diss., l'École pratique des hautes études, 2006.

Lustig, R. Jeffrey. Corporate Liberalism: The Origins of Modern American Political Theory, 1890-1920. Berkeley: University of California Press, 1982.

Lyons, F.S.L. Internationalism in Europe, 1815-1914. Leyden; A.W. Sythoff, 1963.

M. W. Janis, "Jeremy Bentham and the Fashioning of 'International Law'." The American Journal of International Law 78 (1984): 405-418.

Manela, Erez. The Wilsonian Moment: Self-Determination and the International Origins of Anticolonial Nationalism. New York: Oxford University Press, 2007.

Manicas, Peter T. "The Social Science Disciplines." Discourses on Society 15 (1990): 45-71.

Mann, Michael. "The Autonomous Power of the State: Its Origins, Mechanisms and Results." European Journal of Sociology / Archives Européennes De Sociologie 25 (1984): 185-213.

Marotta, Gary. "The Academic Mind and the Rise of U.S. Imperialism: Historians and Economists as Publicists for Ideas of Colonial Expansion." American Journal of Economics and Sociology 42 (1983): 217-234. 
Martellone, Anna Maria. "In the Name of Anglo-Saxondom, For Empire and For Democracy: The Anglo-American Discourse, 1880-1920." In Reflections on American Exceptionalism, edited by David K. Adams and Cornelis A. van Minnen. Staffordshire. England: Keele University Publishing, 1994.

Martin, Geoffrey J. All Possible Worlds: A History of Geographical Ideas. New York: Oxford University Press, 2005.

Mayer, Arno J. Politics and Diplomacy of Peacemaking: Containment and Counterrevolution at Versailles, 1918-1919. New York: Vintage Books, 1967.

Mayer, Arno J. Wilson Vs. Lenin: Political Origins of the New Diplomacy, 19181919. New York: World Publishing, 1969.

McClay, Wilfred M. The Masterless: Self \& Society in Modern America. Chapel Hill: University of North Carolina Press, 1994.

McCormick, Thomas. "From Old Empire to New." In Colonial Crucible: Empire in the Making of the Modern American State, edited by Alfred W. McCoy and Francisco Antonio. Madison: University of Wisconsin Press, 2009.

McGerr, Michael. A Fierce Discontent: The Rise and Fall of the Progressive Movement in America, 1870-1920. New York: Oxford University Press, 2003.

McKay, Ian. "The Liberal Order Framework: A Prospectus for a Reconnaissance of Canadian History." Canadian Historical Review 4 (2000): 617-651.

Mckillen, Elizabeth. "The Unending Debate over Woodrow Wilson and the League of Nations Fight." Diplomatic History 27 (2003), 111-715.

Messer-Kruse, Timothy. The Yankee International: Marxism and the American reform tradition, 1848-1876. Durham: University of North Carolina Press, 1998.

Mitchell, Timothy. "Society, Economy, and the State Effect," in State/Culture: State Formation After the Cultural Turn. Ithaca: Cornell University Press, 1999.

. "The Limits of the State: Beyond Statist Approaches and Their Critics," The American Political Science Review 85 (1991): 77-96. 
- Rule of Experts: Egypt, Techno-Politics, Modernity. Berkeley: University of California Press, 2002.

Montgomery, David. Beyond Equality: Labor and the Radical Republicans, 18621872. Urbana: University of Illinois Press, 1981.

Moore, Gary. "Paul Henry Hanus: A Pioneer in Vocational Education from Academia." Journal of Vocational and Technical Education 10 (1993), 3743.

Moore, James R. The Post-Darwinian Controversies: A Study of the Protestant Struggle to Come to Terms with Darwin in Great Britain and America, 1870-1900. New York: Cambridge University Press, 1979.

Nadelmann, Ethan A. "Global Prohibition Regimes: The Evolution of Norms in International Society." International Organization 44 (1990): 479-526.

Nelson, Keith L. 'The 'Black Horror on the Rhine': Race as a Factor in PostWorld War I Diplomacy." The Journal of Modern History 42 (1970): 606627.

Nemec, Mark R. Ivory Towers and Nationalist Minds: Universities, Leadership, and the Development of the American State. Ann Arbour: University of Michigan Press, 2006.

Ninkovich, Frank. "Theodore Roosevelt: Civilization as Ideology," Diplomatic History 10 (1986): 221-245.

- Global Dawn: The Cultural Foundations of American Internationalism. Cambridge: Harvard University Press, 2009.

- Modernity and Power: A History of the Domino Theory in the Twentieth Century. Chicago: University of Chicago Press, 1994.

- The United States and Imperialism. Malden M.A.: Blackwell, 2001.

- The Wilsonian Century: U.S. Foreign Policy Since 1900, Chicago: University of Chicago Press, 2001.

Novak, William J. "The Myth of the Weak American State," The American Historical Review 113 (2008): 752-772.

Novick, Peter. That Nobel Dream: The 'Objectivity Question' and the American Historical Profession. New York: Cambridge University Press, 1988. 
Nuechterlein, James A. "The Dream of Scientific Liberalism: The New Republic and American Progressive Thought, 1914-1920." The Review of Politics 42 (1980): 167-190.

Numbers, Ronald L. Darwinism Comes to America. Cambridge: Harvard University Press, 1998.

Painter, Nell Irvin. Standing at Armageddon: The United States, 1877-1919. New York: Norton \& Company, 2008.

Patterson, David S. The Search for Negotiated Peace: Women's Activism and Citizen Diplomacy in World War I. New York: Routledge, 2008.

Pérez, Louis A. "We Are the World: Internationalizing the National, Nationalizing the International." The Journal of American History 89 (2002): 558-566

Peterson, Merrill D. The President and His Biographer: Woodrow Wilson and Ray Stannard Baker. Charlottesville: University of Virginia Press, 2007.

Plotkin, Sidney. "War and Economic Crisis: What Would Veblen Say?" Society 47 (2010): 240-245.

Plotkin, Sidney and Rick Tilman. The Political Ideas of Thorstein Veblen. New Haven: Yale University Press, 2011.

Poovey, Mary. A History of the Modern Fact: Problems of Knowledge in the Sciences of Wealth and Society. Chicago: University of Chicago Press, 1998.

Porter, Roy. The Popularization of Medicine, 1650-1850. New York: Routledge, 1992.

Porter, Theodore M. and Ross, Dorothy. The Cambridge History of Science, Volume 7: The Modern Social Sciences. New York: Cambridge University Press, 2003.

Porter, Theodore M. Trust in Numbers. Princeton: Princeton University Press, 1996.

Prozorov, S."Three Theses on 'Governance' and the Political." Journal of International Relations and Development 7 (2004): 278.

Radar, Benjamin G. The Academic Mind and Reform: The Influence of Richard T. Ely in American Life. Lexington, Kentucky: University of Kentucky Press, 1966. 
Rafferty, Edward C. Apostle of human progress: Lester Frank Ward and American political thought, 1841-1913. New York: Rowman \& Littlefield, 2003.

Reisser, Wesley J. The Black Book: Woodrow Wilson's Secret Plan for Peace. Plymouth U.K.: Lexington Books, 2012.

Riccio, Barry D. Walter Lippmann-Odyssey of a Liberal. New Brunswick, N.J.: Transaction Publishers, 1994.

Rodgers, Daniel T. "American Exceptionalism Revisited." Raritan Review 24 (2004): 21-48.

Rodgers, Daniel T. "Exceptionalism." In Imagined histories: American Historians Interpret the Past, edited by Anthony Molho and Gordon Wood. Princeton: Princeton University Press, 1998.

Rodgers, Daniel T. Atlantic Crossings: Social Politics in a Progressive Age. Cambridge: Harvard University, 1998.

Roosevelt, Theodore. The Great Adventure. New York: C. Scribner's Sons, 1918.

Rosenberg, Emily S. Financial Missionaries to the World: The Politics and Culture of Dollar Diplomacy, 1900-1930. Durham: Duke University Press Books, 2004.

Ross, Dorothy. "Anglo-American Political Science, 1880-1920." In Modern Political Science: Anglo-American Exchanges Since 1880, edited by Robert Adcock, Mark Bevir, and Shannon C. Stimson. Princeton: Princeton University Press, 2007.

- "Grand Narrative in American Historical Writing: From Romance to Uncertainty." American Historical Review 100 (1995): 651-677.

- "Socialism and American Liberalism: Academic Social Thought in the 1880s." Perspectives in American History 11 (1978): 35-42.

-The Origins of American Social Science. New York: Cambridge University Press, 1992.

Ross, Earle D. "The Great Triumvirate of Land-Grant Educators: Gilman, White, and Walker," The Journal of Higher Education 32 (1961): 480-488 
Rothbard, Murray N. "Richard T. Ely: Paladin of the Welfare-Warfare State." The Independent Review 5 (2002): 585-589.

Rothberg, Morey. "Introduction: A Home for History," John Franklin Jameson and the Development of Humanistic Scholarship in America: Volume 3, The Carnegie Institution of Washington and the Library of Congress, 1905-1937. Athens: University of Georgia Press, 2004.

- "John Franklin Jameson and the International Historical Community." The History Teacher 26 (1993): 449-457.

Saunier, Pierre-Yves. "Learning by Doing: Notes About the Making of the Palgrave Dictionary of Transnational History," Journal of Modern European History 6 (2008): 159-180.

Schaffer, Ronald. America in the Great War: The Rise of the War Welfare State. New York: Oxford University Press, 1991.

Schneirov, Richard. "Thoughts on Periodizing the Gilded Age: Capital Accumulation, Society, and Politics, 1873-1898." Journal of the Gilded Age and Progressive Era 5 (2006): 189-224.

Schulzinger, Robert. The Making of the Diplomatic Mind: The Training, Outlook, and Style of United States Foreign Service Officers, 1908-1931. Middletown, Conn.: Wesleyan University Press, 1975.

Scott, James C. Seeing Like A State: How Certain Schemes to Improve the Human Condition Have Failed. New Haven: Yale University Press, 1998.

Shafer, David A. The Paris Commune: French Politics, Culture, and Society at the Crossroads of the Revolutionary Tradition and Revolutionary Socialism. New York: Palgrave MacMillan, 2005.

Shepardson, Whitney. Early History of the Council on Foreign Relations. New York: Overbrook Press, 1960.

Skowronek, Stephen. Building a New American State: The Expansion of National Administrative Capacities, 1877-1920. Cambridge University Press, 1982.

Smith, Dusky Lee. "Sociology and the Rise of Corporate Capitalism." Science \& Society 29 (1965): 401-418.

Smith, Neil. American Empire: Roosevelt's Geographer and the Prelude to Globalization. Berkeley: University of California Press, 2004. 
Sproat, John G. The Best Men: Liberal Reformers in the Gilded Age. New York: Oxford University Press, 1968.

Steel, Ronald. Walter Lippmann and the American Century (New York: Transaction Publishers, 1980.

Steigerwald, David. "The Reclamation of Woodrow Wilson." Diplomatic History 23 (1999): 79-99.

Stone, Geoffrey. Perilous Times: Free Speech in Wartime from the Sedition Act of 1798 to The War on Terrorism. New York: Norton, 2004.

Stromquist, Shelton. Reinventing "The People": The Progressive Movement, the Class Problem, and the Origins of Modern Liberalism. Champaign, Ill.: University of Illinois Press, 2005.

Talbott, Strobe. "Self-Determination in an Interdependent World," Foreign Policy 118 (2000): 152-163.

Tenorio-Trillo, Mauricio "Stereophonic Scientific Modernisms: Social Science Between Mexico and the United States, 1880s-1930s." The Journal of American History 86 (1999): 1156-1187.

Thompson, John A. Reformers and War: American Progressive Publicists and the First World War. New York: Cambridge University Press, 2003.

Thompson, John A. "Woodrow Wilson and a World Governed by Evolving Law." The Journal of Policy History 20 (2008): 113-125.

Throntveit, Trygve. "'Common Counsel': Woodrow Wilson's Pragmatic Progressivism, 1885-1913." In Reconsidering Woodrow Wilson: Progressivism, Internationalism, War, and Peace, edited by John Milton Cooper Jr. Washington D.C.: Woodrow Wilson Center Press, 2008.

Throntveit, Trygve. "Leading Them to the Promised Land: Woodrow Wilson, Covenant Theology, and the Mexican Revolution, 1913-1915," Journal of American History 98 (2011): 234-235.

. "The Fable of the Fourteen Points." Diplomatic History 35, no. 3 (2011): 445-481.

Throop, Robert and Lloyd Gordon Ward. "W. I. Thomas and the Suffragists." Toronto: The Mead Project (2007) 
http://www.brocku.ca/MeadProject/Scrapbooks/Circulation/Thomas_a nd_the_suffragists.html (accessed 22 March, 2012)

Tilly, Charles. "The Time of States." In Stories, Identities, and Political Change. New York: Rowman \& Littlefield Publishers, 2003.

Tompkins, E. Berkeley "The Old Guard: A Study of the Anti-Imperialist Leadership." Historian 30 (1968): 366-388.

Torpey, John. "The Problem of American Exceptionalism Revisited," Journal of Classical Sociology 9 (2009): 143-168.

Tyrell, Ian. "American Exceptionalism in an Age of International History." The American Historical Review 96 (1991): 1031-1055.

—. "Making Nations/Making States: American Historians in the Context of Empire." The Journal of American History 86 (1999): 1035.

Vitalis, Robert. "Birth of a Discipline." In Imperialism and Internationalism in the Discipline of International Relations, edited by David Long and Brian C. Schmidt, 159-182. Albany, N.Y.: SUNY Press, 2005.

Wallace, Stuart. War and the Image of Germany: British Academics, 1914-1918. Edinburgh: John Donald publishers Ltd., 1988.

Weinstein, James. The Corporate Ideal in the Liberal State, 1900-1918. Boston: Beacon Press, 1968.

Wertheim, Stephen. "The League That Wasn't: American Designs for a Legalist $\square$ Sanctionist League of Nations and the Intellectual Origins of International Organization, 1914-1920." Diplomatic History 5 (2011): 797-836.

- "The Wilsonian Chimera: Why Debating Wilson's Vision Hasn't saved American Foreign Relations." White House Studies 10 (201 1): 343-359.

Westbrook, Robert."Pragmatism and Democracy: Reconstructing the Logic of John Dewey's Faith." In The Revival of Pragmatism: New Essays on Social Thought, Law, and Culture, edited by Morris Dickstein, 128-40. Durham: Duke University Press Books, 1998.

Whitaker, John K. "Enemies or Allies? Henry George and Francis Amasa Walker One Century Later," Journal of Economic Literature 35 (1997): 1891-1915. 
White, Morton. Social Thought in America $\square$ : The Revolt Against Formalism with a New Preface and an Epilogue. Boston: Beacon Press, 1969.

- Pragmatism and the American Mind. New York: Oxford University Press, 1975.

Wiebe, Robert H. The Search for Order, 1877-1920. New York: Hill and Wang, 1966.

Wilcox, Clifford. "World War I and the Attack on Professors of German at the University of Michigan." History of Education Quarterly 33 (1993), 59-84.

Williams, William Appleman. The Tragedy of American Diplomacy. New York: W.W. Norton, 1988.

Zerby, Charles."John Dewey and the Polish Question: A Response to the Revisionist Historians." History of Education Quarterly 115 (1975): 17-30.

Zinn, Howard. A People's History of the United States: 1492-Present. New York: Harper Perennial, 2003. 